\author{
Szegedi Tudományegyetem \\ Bölcsészettudományi Kar \\ Neveléstudományi Doktori Iskola
}

\author{
RAUSCH ATTILA
}

\title{
KORAI NUMERIKUS KÉSZSÉGEK ONLINE MÉRÉSE
}

$\mathrm{PhD}$ értekezés

Témavezető:

Prof. dr. Csapó Benő

egyetemi tanár

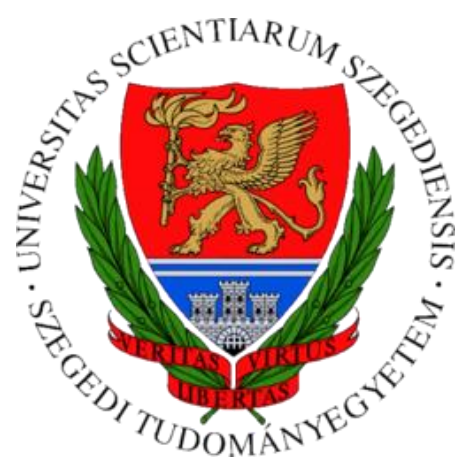

Szeged, 2018 


\section{TARTALOMJEGYZÉK}

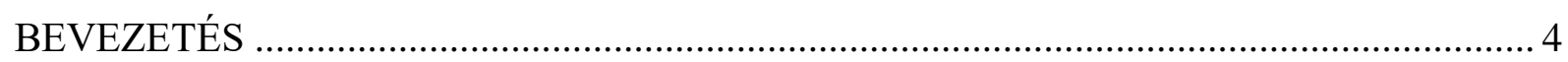

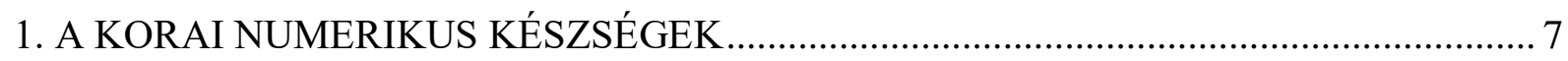

2. A KORAI NUMERIKUS KÉSZSÉGEK FEJLÖDÉSÉNEK MÉRÉSE ........................... 10

2.1. Mérőeszközök a numerikus készségek vizsgálatára ................................................... 10

2.2. Az eszközök jellemzőinek összehasonlítása .......................................................... 20

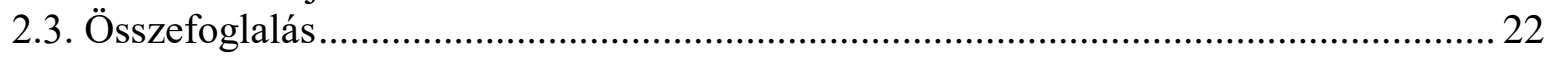

3. FEJLŐDÉSI MODELLEK A KORAI NUMERIKUS FEJLŐDÉS LEÍRÁSÁRA.............. 22

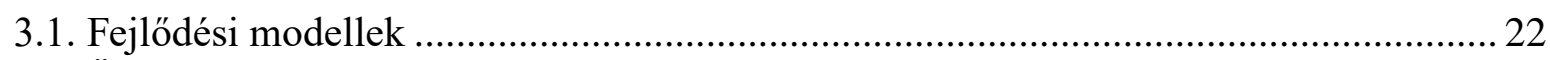

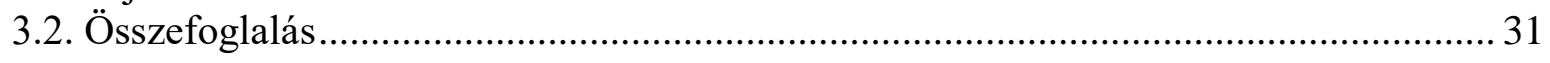

4. MATEMATIKA AZ ÓVODÁBAN ÉS AZ ISKOLA KEZDŐ SZAKASZÁBAN ............ 32

4.1. A hazai óvodai matematikai nevelés tartalma és az iskolakészültség........................... 32

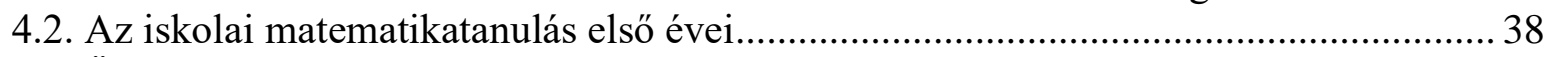

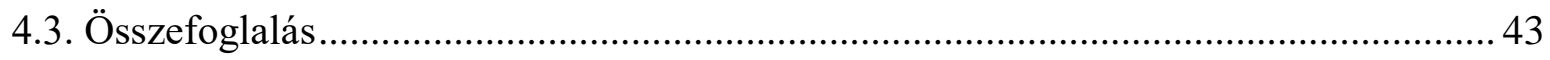

5. DIGITÁLIS ESZKÖZÖK AZ OKTATÁSBAN - A TECHNOLÓGIA ALAPÚ MÉRÉS 43

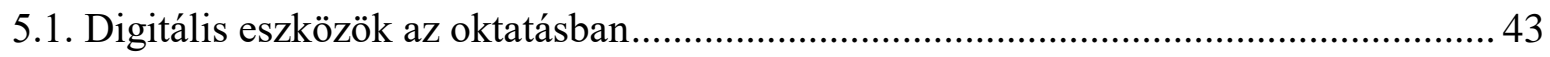

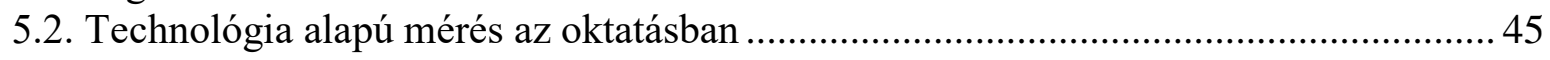

5.3. A technológia alapú mérés lehetőségei és kihívásai kisgyermekeknél .........................51

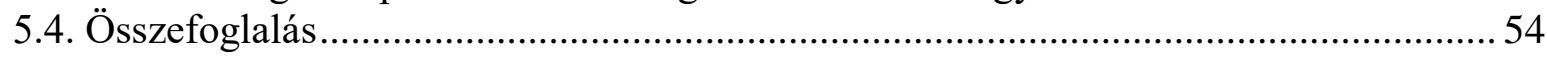

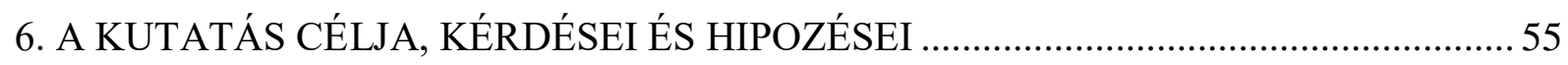

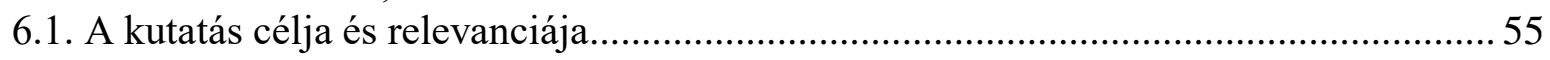

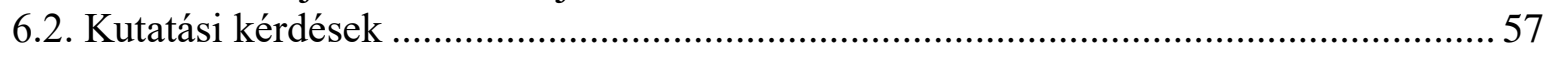

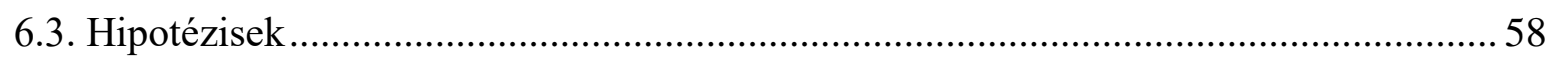

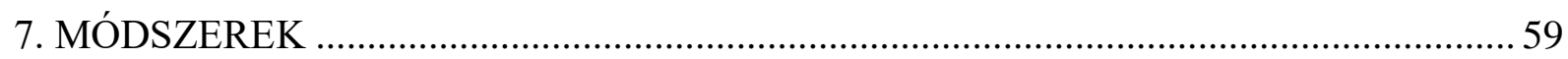

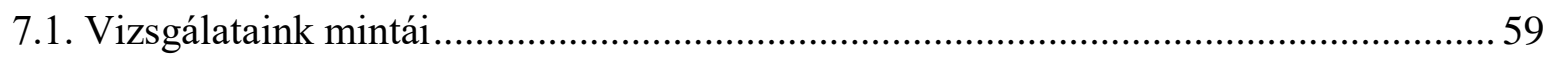

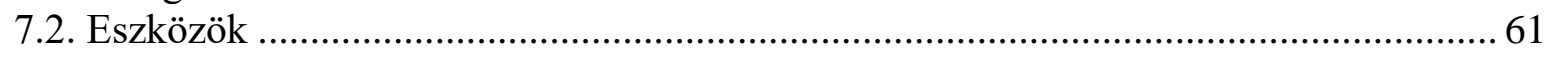

7.2.1. A korai numerikus készségeket vizsgáló teszt kialakítása ..................................... 61

7.2.2. Kutatásunk során kifejlesztett korai numerikus készségeket mérö eszközök ............. 65

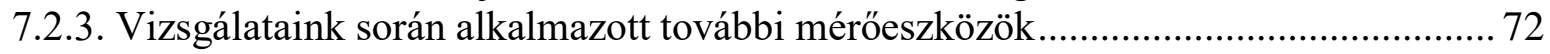

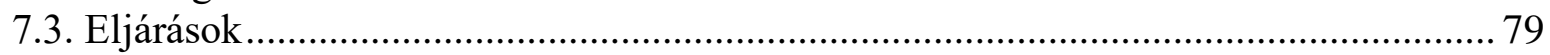

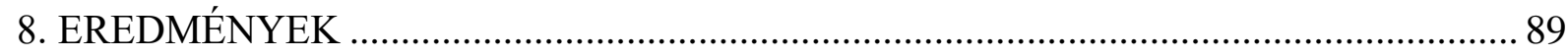

8.1. Az első tesztváltozat pszichometriai jellemzői óvodában ......................................... 89

8.2. Az első tesztváltozat pszichometriai jellemzői első évfolyamon ................................ 99

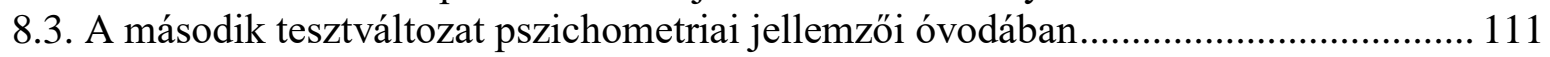

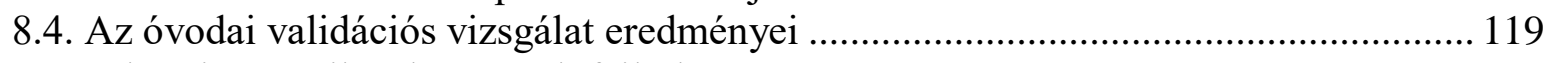

8.5. A korai numerikus készségek fejlődése ............................................................. 126

8.6. A korai numerikus készségek és az első évfolyam végi matematika teljesítmény ..... 131

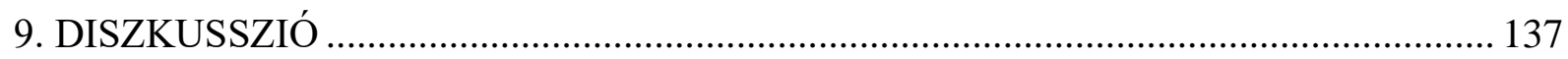

9.1. A korai numerikus készségek teszt pszichometriai jellemzőinek megvitatása ........... 137

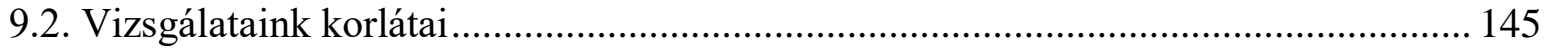

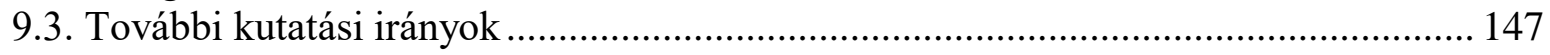

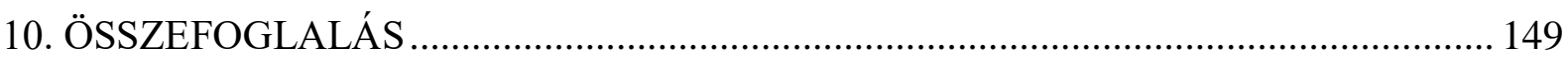




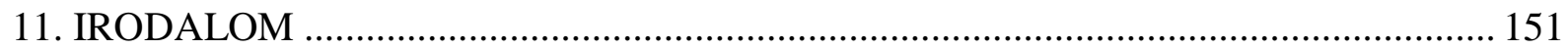

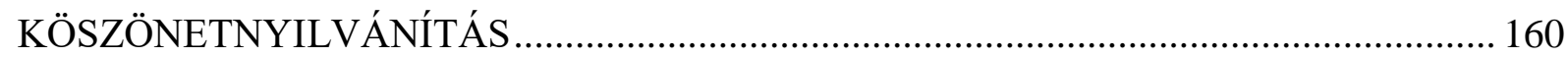

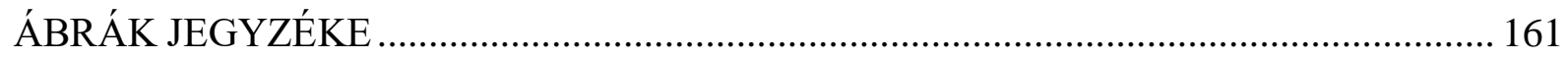

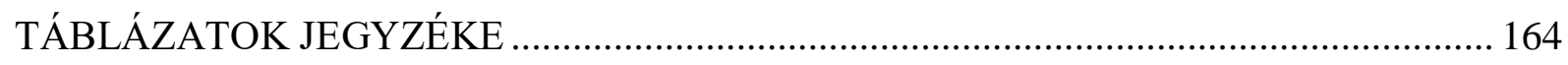

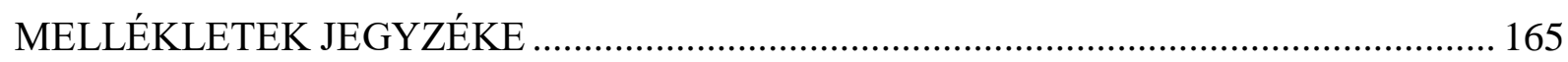

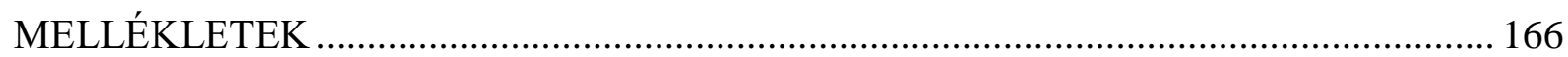




\section{BEVEZETÉS}

„A matematika a kulcs és az ajtó a tudományokhoz” - mondja Galilei, amely gondolatban megmutatkozik, hogy a matematikának kiemelkedő szerepe van a tudományok között, hiszen tudományos kutatásokhoz ismerni kell a matematika nyelvét, amely tudományos gondolkodásmódot is közvetít. Alapvető matematikai eljárások ismeretére és alkalmazására azonban nem csak tudósoknak van szükségük. Legyen szó a hétköznapi élet olyan különféle helyzeteiről, mint a vásárlás, pénzügyek intézése, legyen szó a munka világának egyszerübb és bonyolultabb problémahelyzeteiről, mindenki találkozik matematikával. Egyre kevesebb olyan szakma van, ahol ne kerülnének elő matematikai tartalmak, vagy ne lenne szükség olyan gondolkodási képességekre, amelyek a matematika által kiválóan fejleszthetők (Nunes \& Csapó, 2011). Eközben hazánkban a PISA-mérések eredményeiből világossá vált, hogy komoly problémák vannak a magyar tanulók matematikai műveltségével, az átlageredmények csökkenése mellett riasztó mértékben növekedett a leszakadók aránya (Csapó, Fejes, Kinyó, \& Tóth, 2014). A tanulók jelentős része nincs tisztában, illetve nem tudja alkalmazni már az iskola alsó tagozatában tanultakat sem. Az utóbbi évtized nemzetközi kutatásai mutattak rá, hogy a problémák gyökereit érdemes már az iskolakezdés időszakában keresni, a családi háttér, az iskolai szelekció mellett, a korai matematikatanulás jelentőségére irányul egyre több figyelem (Jordan, Kaplan, Ramineni, \& Locuniak, 2009; Friso-van den Bos, Kroesbergen, \& van Luit, 2014). Mivel az óvoda-iskola átmenet számolási készségeinek fejlettsége jelentős mértékben befolyásolja a tanulók későbbi teljesítményét, ezért ha a tanulók numerikus készségei nem kellőképp fejlettek mikor elkezdik az iskolát, akkor később komoly hátrányt szenvedhetnek el (Jordan et al., 2009).

A korai numerikus készségek olyan öröklött és szerzett, szimbolikus és nemszimbolikus összetevők, egymással összefonódó, egymásra épülő és párhuzamosan fejlődő készségek és ismeretek rendszere, amelyek nélkülözhetetlenek az iskolai matematikatanuláshoz, a különböző matematikai tartalmi területek megismerésében fontos szerepet töltenek be. A numerikus készségek közé tartozik a számok nevének, sorrendjének és jelének megismerése, mennyiségek észlelésével, számolási műveletek végzésével kapcsolatos készségek összessége, valamint alapvető matematikai fogalmak és összefüggések megértése is. Az ezen területen fellépő hiányosságok gátolhatják új matematikai fogalmak megértését, az iskolai matematikatananyagban való elörehaladást. Ennél fogva fontos szerep jut a fejlesztésnek, a lemaradók felzárkóztatását célzó programoknak, amelyek hosszú távú hatékonyságát növelheti a minél korábbi kezdés. Korábbi vizsgálatokból tudjuk, hogy az elemi 
alapkészségek fejlődésének mértéke óvodás korban még nagymértékben befolyásolható (Józsa, 2004), valamint az óvodás és kisiskoláskori fejlesztések eredményességét már több esetben bizonyították (Józsa, 2007; Molnár, 2011). Annak érdekében viszont, hogy a gyermekek számára célirányos fejlesztéseket biztosítsunk, időben észlelnünk is kell a problémákat. Mindez nem valósulhat meg olyan mérőeszközök biztosítása nélkül, amelyek minden gyakorló pedagógus számára gyorsan és könnyen használhatók, egyben pontos és megbízható képet biztosítanak a felmért gyermekek numerikus készségeinek fejlettségéről.

Napjainkban a felgyorsult technológiai fejlödés eredményeképpen nagymértékben tör előre a technológia alapú mérés-értékelés pedagógiai célú alkalmazása, lehetőségeit már egyre fiatalabb életkorú gyermekek körében is ki tudjuk használni. Számítógépek segítségével lehetőség nyílik a numerikus készségek elektronikus tesztelésére is. Bár a mérés-értékelés e formája rengeteg lehetőséget hordoz magában, a kutatók előtt álló kihívások köre legalább ekkora mértékü. Az ilyen eszközök széles körü alkalmazása ugyanakkor elősegítheti azt, hogy gyermekek széles körének fejlettségét felmérve, teljesítményüket automatikusan kiértékelve azonosítsuk azokat a tanulókat, akikre az elektronikus mérésekkel megspórolt időkeretben a pedagógus több figyelmet tud fordítani. A csoportszintű átlageredményeket pedig fejlesztő foglalkozások megtervezésében tudják majd jól hasznosítani. Kutatásunk során egy ilyen eszköz kidolgozására vállalkoztunk.

Munkánkban egy korai numerikus készségeket vizsgáló online teszt fejlesztésének folyamatát, az ehhez kapcsolódó óvodások és első évfolyamos tanulók körében végzett vizsgálatok eredményeit mutatjuk be. A disszertáció első fejezetében meghatározzuk a korai numerikus készségek fogalmát, majd áttekintjük ennek kialakulását. Ezt követően a második fejezetben a numerikus készségek kisgyermekkori tesztelésének formáira térünk rá, bemutatunk és összehasonlítunk különböző nemzetközi mérőeszközöket és egy hazai gyakorlatban elterjedt tesztet. A harmadik fejezetben több fejlődési modellt és korábbi vizsgálatok empirikus eredményeit is felhasználva mutatjuk be a korai numerikus készésgek fejlődését. A negyedik fejezetben intézményi keretbe helyezzük a numerikus készségek 4 és 8 év közötti fejlödését, az óvodai matematikai nevelés rendszerét, tartalmát, valamint az általános iskola első két évfolyamának matematikai tartalmi részeit tárgyaljuk, amelyet követően rövid kitekintést nyújtunk az elsajátított matematikatudás alkalmazására és a magyar tanulók PISAméréseken elért matematika eredményeire. Az ötödik, egyben utolsó elméleti fejezetben összefoglaljuk a technológia alapú mérés-értékelés fogalmát és jellemzőit, ennek elején a digitális technológiai fejlődés oktatásra gyakorolt hatásáról írunk, ezután a technológiai alapú mérés-értékelést jellemzésénél az abban rejlő számtalan lehetőségre, és azokra a korlátokra is, 
amikkel még szembesülhetünk különösen kisgyermekek körében végzett vizsgálatoknál. A dolgozat hatodik fejezetében kutatásunk célját, kérdéseit és hipotéziseit ismertetjük. A hetedik fejezet az elvégzett vizsgálatok módszereiről nyújt átfogó képet. Itt a vizsgálatok mintái és eljárásai mellett részletesen mutatjuk be a korai numerikus készségek online mérésére kifejlesztett tesztünk első, és második - átdolgozott változatát, valamint itt kap helyet minden további kutatási eszközünk ismertetése. A nyolcadik fejezet tartalmazza empirikus vizsgálataink eredményeit. Ennek alfejezeteiben a tesztek pszichometriai jellemzőiről, egy óvodai validációs mérés eredményeiröl, keresztmetszeti és longitudinális elemzéseinkröl írunk. A kilencedik fejezetben pedig megvitatjuk az eredményeinket, bemutatjuk a kisgyermekek numerikus készségeinek online tesztelésére vonatkozó következtetéseinket, valamint a vizsgálatok pedagógiai relevanciája mellett kitérünk vizsgálataink korlátaira is. Végül a disszertációt összegzéssel zárjuk, amelyben felvázoljuk a további lehetséges kutatási irányokat is.

A disszertáció megírásához korábbi tanulmányaink egyes részeit használtuk fel, jelentősen átdolgozva, a dolgozat módszerei között, és az eredményekre vonatkozó fejezetekben (Rausch, 2017; Rausch \& Pásztor, 2017). A kutatások nem valósulhattak volna meg az MTA-SZTE Képességfejlődés Kutatócsoport, az SZTE Oktatáselméleti Kutatócsoport és az SZTE Neveléstudományi Doktori Iskola intézményeinek szakmai támogatása és infrastruktúrájának felhasználása nélkül. A disszertáció megírásának időszakában a szerző a Nemzeti Tehetségprogram ösztöndíjában részesült. 


\section{A KORAI NUMERIKUS KÉSZSÉGEK}

A korai numerikus készségek (early numerical skills) képezik az iskolai matematikatanulás alapját, a matematika minden részterületének megismerésében és fejlődésében szerepet játszanak. Amint azt Richard Skemp (1975) is írja, már egészen kis gyermekekben kialakulhat egy kezdetleges számfogalom, és úgy tünhet, hogy pontosan meg tudják állapítani egyes halmazok számosságát, válaszaik mögött mégsem húzódik tényleges számfogalom. Az anyanyelv elsajátításával együtt a számok nevét is viszonylag hamar megtanuljuk, és ezeket egymás utáni sorrendben is egészen gyorsan elkezdjük mondogatni. Ha megkérünk egy 2-3 éves kisgyermeket, hogy számoljon el ameddig csak tud, akár húszig is hibátlanul elszámol, azonban a kimondott számok mögött lévő mennyiségekkel, tartalommal csak később lesz pontosan tisztában. Skemp szerint ez egészen addig nem probléma, amíg ezt a látszólagos számfogalmat nem keverjük össze a valódival, és megfelelő alapozás nélkül nem kezdjük el a matematikát írott szimbólumokkal is tanítani (Skemp, 1975).

Azokat az alapvető összetevőket nevezzük korai numerikus készségeknek, amelyeknek köszönhetően a gyermekek megértik a számokat és az azok közötti kapcsolatokat (Aunio \& Niemivirta, 2010). A numerikus készségek fejlődését és a számfogalom kialakulását két alapvető rendszer fejlődése előzi meg. Az első a számérzék (number sense), ez már a számok nevének megtanulása előtt jelen van, és mennyiségek felismerését segíti már nagyon fiatal korban is (Dehaene, 2003). A számérzék definiálásában kisebb eltérés tapasztalható a neveléstudományi és a neuropszichológiai tanulmányokban. A neveléstudományi kutatásokban ebbe különböző készségek beletartozhatnak, amelyek már a formális nevelés időszaka előtt jelen vannak és a becslésnél, mennyiségek felismerésénél és összehasonlításánál mutatkoznak meg (Jordan et al., 2007). A neuropszichológusok által képviselt álláspont a számérzéket szükebb értelemben használja, azokra a numerikus képességekre érti, amelyeket nem csak az embereknél, hanem az állatoknál is megfigyeltek (Dehaene, 2003). A másik alapvető rendszer a tárgyak követése, ami kisebb mennyiségek, de lényegesen pontosabb követéséért felel. Ennek szemléltetésére a legismertebb kísérletet Wynn (1992) végezte csecsemőkkel. Vizsgálatában egy tárgyat mutattak csecsemőknek, majd eltakarták, utána egy újabb tárgyat mutattak és azt is takarásba helyezték, végül a takarást elvéve a csecsemők egy vagy két tárgyat láttak. A csecsemők reakciói alapján azt lehet feltételezni, hogy tudták követni a tárgyak számát, azonban csak kis mennyiségek esetén, legfeljebb három tárgyig.

A kisgyermekek numerikus megismerésének kutatása az elmúlt évtizedekben a kognitív tudomány és a neuropszichológia egyik kiemelkedő vizsgálati területe lett, amelynek 
köszönhetően az utóbbi évtizedekben egyre többet tudtunk meg a kisgyermekek számolásának fejlődéséről, és legfőképp az eltérő fejlődés, számolási zavarok okairól, továbbá evolúciós és humánetológiai megközelítésü vizsgálatok eredményei is hozzájárultak egyes modellek kidolgozásához.

A korai numerikus fejlődés megértéséhez Dehaene (2003) hármas kódolás elmélete tekinthető olyan mérföldkőnek, amelyre azóta számos vizsgálat épített, és amelyet többen is kiegészítettek, továbbfejlesztettek már. Az 1. ábrán ezt a hármas kódolási modellt láthatjuk, amelyet Dehaene (2003) és McCloskey (1992) elméleteire alapozva készített Igács, Janacsek és Krajcsi (2008). Ebben nem csak a három fő komponens, a mennyiségi, verbális, és arab szám rendszere szerepel, hanem a mellettük numerikus fejlődésben fontos funkciót betöltő összetevők összekapcsolódása is látható, a hozzájuk kötődő fogalmak, matematikai eljárások, ismeretek kiegészítésével.

A mennyiségek, verbális és arab számok rendszere tehát együttesen képezik a számolás alapjait. Először Dehaene (2003) munkája alapján ismertetjük ezt a három fogalmat, amelyek közül az analóg mennyiségi rendszer, a szakirodalomban elterjedtebb nevén, mentális számegyenes (mental number line) az első. A mentális számegyenes egy nem-szimbolikus rendszer, amely kezdetben logaritmikus skálának tekinthető, meglehetősen felületesen tárolja a mennyiségeket, melyek alacsonyabb számkörben pontosabban helyezkednek el, magasabb számkörökben egyre pontatlanabbul reprezentálódnak (Fritz, Ehlert és Balzer, 2013). Becslésnél és közelítő számolásnál lehet ezt a rendszert viszonylag megfelelően használni (Igács, Janacsek, \& Krajcsi, 2008), viszont amikor pontos és megbízható számolásra van szükségünk, akkor vesszük igénybe a verbális rendszert. A verbális rendszer tárolja a számok verbális elnevezését, viszont ide sorolható a szavakkal leírt számok köre is, tovább különböző már megismert és megtanult aritmetikai tényeket is ide sorolhatunk. Ez a rendszer és a következő rendszer is már szimbolikus, mivel a számok nyelvi szimbólumainak tárolását és feldolgozását végzik. A verbális rendszerben elérhető információ mindig pontosnak tekinthető, ugyanakkor az ebben megjelenő számok, aritmetikai tények mögött nincsen tartalom, valódi jelentésük megértéséhez a mennyiségi rendszer használata szükséges. A mentális számegyenessel összekapcsolódva válnak értelmezhetővé a verbális számok, így tudjuk a mögöttük álló mennyiségeket elképzelni. E kettő rendszer mellett helyezkedik el az arab számok rendszere, ebben tárolódnak a számok írott jelei, és az arab számok felismerése és feldolgozása is itt történik (Dehaene, 2003; Igács, Janacsek, \& Krajcsi, 2008; Peucker \& Weißhaupt, 2013). 
Számolási műveletek

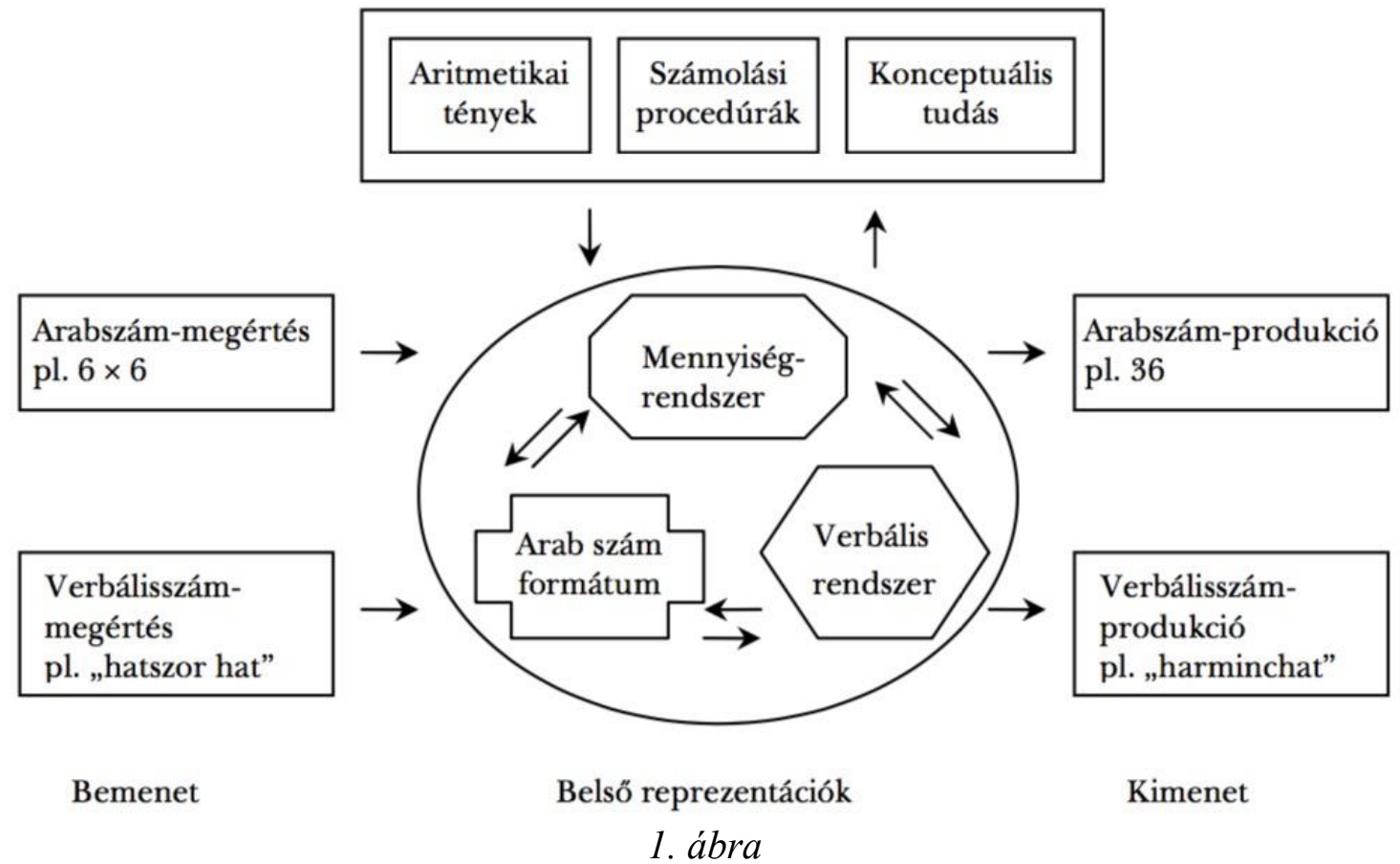

Numerikus megismerésben szerepet játszó rendszerek és reprezentációk (Igács, Janacsek, \& Krajcsi, 2008, p. 636)

A bemutatott három rendszert Krajcsi (2010) szerint McCloskey modellje megerösíti és kiegészíti, melyben az aritmetikai tények, a számolási procedúrák és konceptuális tudás szoros kapcsolatban állnak a másik három rendszerrel, és amelyek egyszerübb folyamatai idővel automatizálódnak (Igács, Janacsek, \& Krajcsi, 2008).

A hármas kódolás rendszerében is megjelenhet a nyelv és a gondolkodás összekapcsolódásának kérdése (Chomsky, 2006). Vajon mennyiben határozza meg a nyelv a gondolkodásunkat, milyen hatással van annak fejlödésére. Mivel dolgozatunknak nem célja e kérdéskörben állást foglalni, és részletesen tárgyalni az erre vonatkozó nyelvi univerzalizmus, vagy determinizmus fogalmait, ezért most csak azokra a nyelvi összetevőkre térünk ki, amelyek általánosságban jelennek meg a kisgyermekek számolásának fejlődésénél. Természetesen az egyik ilyen összetevő a szókincs, a verbális számolás a számok nevének mondóka jellegü ismeretével kezdődik. Bár lehet, hogy felnőttkorunkban már teljesen természetesnek tünik használatuk, a számok és sorszámnevek elnevezéseit megtanulni hosszú időbe telik. Továbbá a gyermekek későbbi fejlödésük során anyanyelvük számneveinek megtanulása mellett, megismerkednek az adott nyelvre jellemző szabályokkal is, hiszen bár egyes nyelvek között jelentős eltérések vannak, egyfajta szisztematikus szabályrendszer mindegyikre jellemző. Ennek megtanulása, begyakorlása pedig összefügg a számolási készségek fejlődésével. A 
Dehaene elméletében is szereplő analóg mennyiségi rendszerrel ellentétben, a verbális szókeret, a számok nevei, valamint a számok írott jelei, az arab számok segítségével vagyunk csak képesek pontos és magasabb szintű számolási műveleteket elvégezni (Krajcsi, 2014).

\section{A KORAI NUMERIKUS KÉSZSÉGEK FEJLŐDÉSÉNEK MÉRÉSE}

A numerikus készségek vizsgálatára az elmúlt évtizedek során több mérőeszközt is kidolgoztak már. Ezek között találunk olyanokat, amelyek kutatói és pedagógiai igényeket egyaránt kiszolgálnak, olyanokat, amelyek gyermekek iskolaérettség-vizsgálatának részét képezik, és olyan diagnosztikus eszközt is, amely a pedagógusok munkáját, a gyermekek célirányos fejlesztésének megtervezését hivatott megkönnyíteni.

Ebben a fejezetben ilyen eszközöket mutatunk be, először a nemzetközi kutatásokban egyik leggyakrabban alkalmazott ENT-et (Utrech Early Numeracy Test), egy angol-szász mérőeszközt, a WENT-et (Wright Early Numeracy Test), egy német diagnosztikus tesztet, a MARKO-D-t (Mathematik und Rechnen Konzepten - Diagnose), és a hazai fejlesztésü DIFER Elemi számolási készség tesztet. A neuropszichológusok által alkalmazott, számolási zavarok diagnosztizálására alkalmas eszközökről, valamint pszichológiai kísérleti vizsgálati eljárásokról azonban nem értekezünk, mivel azok nem illeszkednek pedagógiai célú vizsgálatainkhoz, és felvételüket óvodapedagógusok, tanítók nem végezhetik, az speciális képzettséghez kötött.

\subsection{Mérőeszközök a numerikus készségek vizsgálatára}

Ebben az alfejezetben röviden ismertetjük a korábban felsorolt három pedagógiai célú, numerikus készségeket vizsgáló tesztek leírását, fő tartalmi elemeiket, a mért készségek, műveletek szerkezetét, valamint a tesztfelvétel menetének általános jellemzőit. A tesztek bemutatáskor kitérünk arra is, hogy kidolgozásuk óta milyen területen, milyen tapasztalatokkal alkalmazták már azokat. A következő alfejezetben pedig összegezzük a bemutatott eszközök legfőbb jellemzőit, a velük végzett vizsgálatok tapasztalatait, és meghatározott szempontok mentén össze is hasonlítjuk, értékeljük azokat. 
Az egyik legelterjedtebb mérőeszköz gyermekek számolási készségek mérésére az ENT (Utrecht Test of Early Numeracy). A Van Luit, Van de Rijt és Pennings (1994) által kidolgozott tesztet 4-8 éves korú gyermekek számolási készségeinek vizsgálatához alkalmazzák. Az eszköz összesen 40 itemet tartalmaz, ezek nyolc résztesztre osztódnak, amelyekből négy mennyiségek és relációk megértéséhez kapcsolódik, ezek között szerepel mennyiségek összehasonlítása, csoportosítása, egy az egyhez rendelése, valamint sorba rendezése (szerializáció). Emellett a számok megértésének vizsgálatára tartalmaz még a teszt feladatokat, melyekkel a számok használata, strukturált számlálás, rezultatív számlálás és a számok általános ismerete mérhető (Van Luit, Van de Rijt, \& Pennings, 1994; Van de Rijt, Van Luit és Pennings, 1999).

A teszt első felében a mennyiségek és relációk koncepciójának vizsgálatán van a hangsúly. A mennyiségek összehasonlítása résztesztben csoportosítás feladatainál adott tárgyak bizonyos jellemzői szerinti osztályozását vizsgáljuk. Az egy az egyhez rendeléses feladatokban egyidejüleg több, adott mennyiségeket ábrázoló képeket mutatunk a gyermeknek, amelyekkel azt vizsgáljuk, hogy megértik-e a kapcsolatot ezek között. A sorba rendezéses feladatok célja, hogy megmérje a gyermekek sorba tudják-e rakni adott elemeket mennyiségük, méretük, hosszúságuk szerint (Van de Rijt, Van Luit és Pennings, 1999).

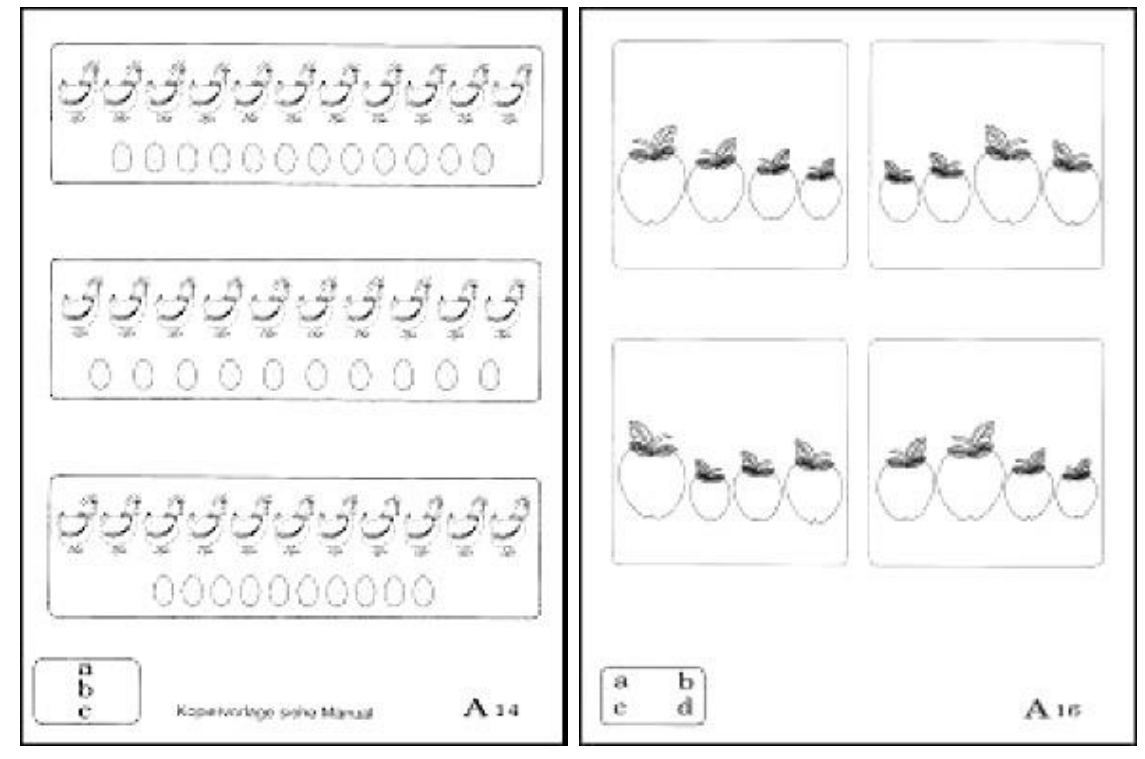

2. ábra

Példafeladatok az ENT tesztböl (Van Luit, Van de Rijt, \& Hasemann, 2001)

A teszt második felének négy résztesztje a számok megértésével foglalkozik. Ezek közül az első részben a számnevek használatát vizsgáljuk. A gyermekeknek pozitív egész 
számokat kell elörefelé és visszafelé felsorolniuk 20-as számkörön belül. Ezt követi a strukturált számolás, amelynél az asztalon elhelyezett tárgyakat kell a gyermekeknek megszámolniuk, miközben azokra rámutatnak az ujjukkal. Ezután jönnek a rezultatív számolás feladatai, amelyeknél a kardinalitás fogalmának megértését vizsgáljuk. Itt az előző részhez hasonlóan tárgyakat kell megszámolni, viszont azokra már nem mutathat a gyermek, és a mérőbiztos a tárgyak számát kérdezi (Van Luit, Van de Rijt, \& Pennings, 1994). Végül az utolsó résztesztben a számok általános megértését vizsgáljuk. Ezekben a feladatokban szituációkba helyezve különböző számolási műveletek elvégzését kérjük: „Van kilenc üveggolyód. Elveszítesz közülük hármat. Mennyi maradt? Rá tudsz mutatni arra a képre, ahol a helyes számú üveggolyót látod?” (Van de Rijt, Van Luit és Pennings, 1999, p. 291).

A tesztfelvétel ennél a tesztnél is egyénileg történik, és nagyjából 30 percet vesz igénybe gyermekenként. A mérőbiztos és a gyermek egy asztal két szélén helyezkednek el, a tesztfelvételnél a feladatok egy része kikérdezéssel történik, a feladatok többi részében feladatlapokat mutatunk a gyermeknek, valamint egyes számolási feladatoknál korongokat is használunk. A tesztleírás szerint nem szabad visszajelzést adni a gyermeknek (Van Luit, Van de Rijt, \& Pennings, 1994; Van de Rijt, Van Luit és Pennings, 1999).

A teszt jóságmutatói kiválóak az elérhető szakirodalom alapján, reliabilitása (Cronbach$\alpha=0,90)$ és konstruktum-validitása egyaránt magas ( $\mathrm{CFI}=0,95 ; \mathrm{RMSEA}=0,04)$ (Aunio, Hautamäki, Heiskari, \& Van Luit, 2006; Aunio \& Niemivirta, 2010). A mérőeszközzel elsősorban európai neveléstudományi kutatásokban találkozhatunk, megjelenése óta az első holland méréseket (Van de Rijt, Van Luit \& Pennings, 1999) követően többek között készült már német nyelvü változat (Van Luit, Van de Rijt \& Hasemann, 2001), finn (Aunio et al., 2006) és spanyol (Navarro, Aguilar, Alcalde, Marchena, Ruiz, Menacho, \& Sedeño, 2009) tesztváltozat is. A teszttel a számolási készségek más készségekkel, képességekkel való összefüggését (Kyttälä, Aunio, Lehto, Van Luit, \& Hautamäki, 2003), azok iskolai matematika eredményekre gyakorolt hatását (Aunio \& Niemivirta, 2010), különböző háttérváltozók fejlődésben játszott szerepét (Kleemans, Peeters, Segers, \& Verhoeven, 2012), alkalmazták nemzetközi összehasonlító vizsgálatokra (Aunio, Aubrey, Godfrey, Pan, \& Liu, 2008), és nem utolsó sorban, számos fejlesztőprogram hatékonyságát is vizsgálták már vele (Van Luit, \& Schopman, 2000; Aunio, Hautamäki, \& Van Luit, 2005). Azonban kevés olyan szakirodalom lelhető fel, ahol a pedagógiai gyakorlatban való alkalmazásáról olvashatnánk. 
A Wright, Martland és Stafford (2006) ausztrál kutatók által kifejlesztett WENT (Wright Early Numeracy Test) kifejezetten pedagógusoknak készült óvodai és iskolai használatra. A tesztet elsősorban angol nyelvterületen alkalmazzák, és részletesen kidolgozott, három tartalmi területből, aritmetikai készségekből, számlálás és arab szám felismerés készségeiből, valamint mennyiségekkel végzett müveletek, számolások részterületeiből álló keretrendszer, és konstruktív, egymásra épülő gyakorló feladatokból álló óvodai-iskolai fejlesztési programterv is kapcsolódik hozzá (Wright, Stanger, Stafford, \& Martland, 2006).

\begin{tabular}{|c|c|}
\hline Előrefelé számolás & Következő szám \\
\hline $\begin{array}{l}\text { Kezdj el számolni számolni ...-tól és } \\
\text { szólok, amikor abbahagyhatod. }\end{array}$ & $\begin{array}{l}\text { Mond meg azt a számot, amelyik egyből } \\
\qquad a(z) \text {... után jön! }\end{array}$ \\
\hline $\begin{array}{ll}\text { (a) } 1(\text { to } 32) & \text { (b) } 48 \text { (to } 61) \\
\text { (c) } 76(\text { to } 84) & \text { (d) } 93 \text { (to } 112)\end{array}$ & $\begin{array}{c}\text { (b) Less advanced task } \\
59_{3} \quad 7\end{array}$ \\
\hline
\end{tabular}

Példafeladatok a WENT tesztböl (Wright, Martland, \& Stafford, 2006, p. 36)

A teszt 6 részből tevődik össze, amelyek a tartalmi keretrendszerhez kapcsolódnak, és amelyek mindegyikén belül 3-6 fejlettségi szintet határoztak meg adott készség tartalmának és műveleteinek megfelelően (lásd: 3. ábra Előrefelé számolás (b) 2. fejlettségi szint feladata). Az első a számok sorrendje előrefelé, pontosabba az előrefelé számolás (Forward Number Word Sequences), ezt követi a visszafelé számolás (Backward Number Word Sequence). Mindkét rész feladatainál egy adott számot mond a mérőbiztos, és a gyermeknek onnan kell folytatnia a számolást előre vagy visszafelé, ameddig a mérőbiztos le nem állítja. Mindkét feladatrészhez tartoznak emellett olyan feladatok is, amelyeknél csak a számsorban a következő, vagy előző számot kell a gyermeknek megneveznie (3. ábra). A következő feladatrész az arab számok felismerése (Numeral Identification). Ezekben a feladatokban a mérőbiztos számkártyákat helyez az asztalra véletlenszerü sorrendben, egymást követően több szettet, egyre magasabb számkörökben. A gyermeknek rá kell mutatnia a mérőbiztos által mondott számra. Ez után jön a számolás (Counting) több kisebb alegységből álló tesztrésze. Ebben az részben az első feladatoknál a mérőbiztos által asztalra helyezett egyszínű korongokat kell megszámolni, ezt 
követően adott mennyiségü piros és kék korongot kell összeadni 20-as számkörben. A további feladatokban a méróbiztos elvesz a halmazból és a maradék mennyiségre kérdez rá: „Volt 8 korongom, elvettem belöle 3-at. Mennyi korongom maradt?” (Wright, 2013, p. 35). Ezt pedig olyan itemek követik, amelyeknél hasonló elrendezésben a jól láthatóan elvett korongok számára kérdezünk rá. Az ötödik feladatrészben, amit a szerzők számok konstruálásának neveznek (Structuring numbers), először a gyermekektől adott mennyiség megmutatását kérik az ujjaik segítségével, amelyet szubitizációs feladatok követnek, végül pedig halmazokkal kell müveleteket végezniük. Iskolás korosztályban ez kiegészül arab számokkal végzett 20-as számkörön belüli mủveletekkel is. Az utolsó feladatrész a konceptuális helyiérték (Conceptual place value) nevet viseli, amely részben az itemek a helyiérték fogalmának megértését vizsgálják. A feladatokban a 10-esekkel történő előre és visszalépések megértését mérik (Wright, Martland, \& Stafford, 2006; Wright, 2013).

A teszt felvétele szemtől szemben zajlik, a feladatokon interjús kikérdezés jelleggel halad végig a mérőbiztos. Egyes feladatrészekhez számkártyákat, korongokat (piros és kék), pálcikákat is szükséges előkészíteni, amelyekkel vagy a gyermek végez számolást, vagy legtöbbször a méröbiztos szemlélteti a müveletet. A teljes teszt adminisztrálása akár egy teljes órát is igénybe vehet, ezért javasolt a több részletben való kikérdezés (Wright, Martland, \& Stafford, 2006). A tesztet pedagógiai és kutatási célból egyaránt lehet alkalmazni, az erre épülő programhoz előzetes felvételét mindenképp ajánlják az óvodapedagógusoknak, tanítóknak (Wright, Stanger, Stafford, \& Martland, 2006).

\section{MARKO-D}

A Ricken, Fritz és Balzer (2013) által kidolgozott, az iskola előtt álló gyerekek matematikai készségeinek diagnosztikus értékelésére szolgáló, és elsősorban német nyelvterületen alkalmazott mérőeszköz a MARKO-D (Mathematik und Rechnen - Test zur Erfassung von Konzepten im Vorschulalter). A teszt egy Annemarie Fritz által vezetett kutatási projekt részeként jött létre, amelynek első fázisa és a teszt összeállításának előzménye az elméleti fejezetben ismertetett öt szintű korai matematikai kompetenciamodell kidolgozása volt (Fritz, Ehlert, \& Balzer, 2013). A MARKO-D erre a fejlődési modellre épül, összesen 55 itemből áll, melyek az elméleti modell egyes lépcsőihez illeszkednek. 


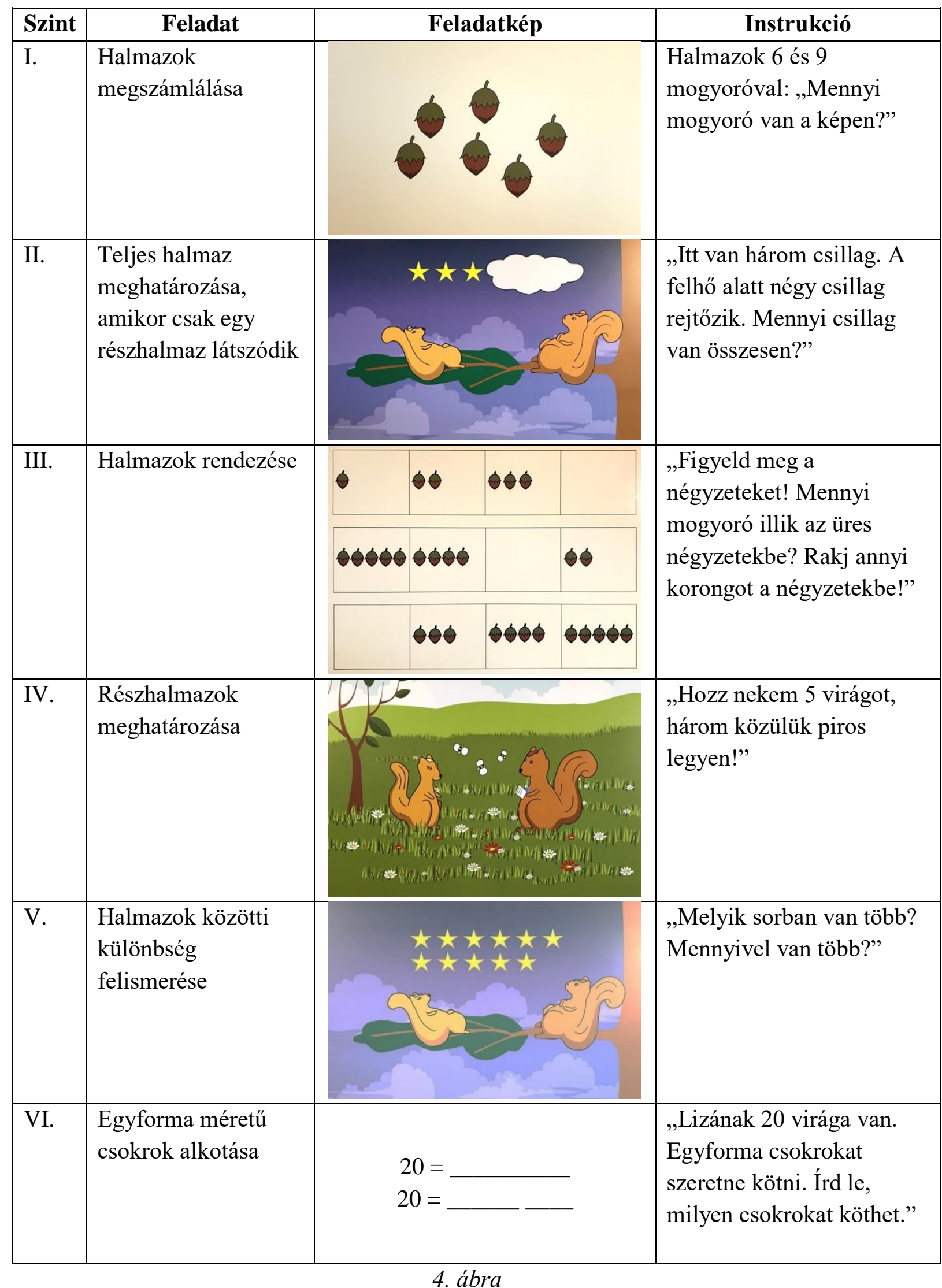

Példafeladatok a MARKO-D tesztböl fejlödési szintenként

(Forrás: Ricken, Fritz, \& Balzer, 2013; Fritz, Ehlert és Balzer, 2013, p. 53-54 alapján) 
A mérőeszköz többek között vizsgálja a számfelismerést, számsorrendeket, a számjegy és a mennyiség egy az egyhez rendezéssel történő összekapcsolását, a számsorral, számegyenessel kapcsolatos műveleteket, továbbá a mennyiségek összevonására, csökkentésére irányuló, valamint a rész-egész kapcsolatra vonatkozó tudást. A teszt feladatainak sorrendje azonban nem követi a modell szintjeit, az alacsonyabb és magasabb nehézségü itemek keverten jelennek meg az eszközben. Ricken, Fritz és Balzer (2013) szerint ennek a felépítésnek az a célja, hogy az alacsonyabb fejlettségi szinten lévő gyerekeket is motiválják a teszt teljesítésére.

A MARKO-D feladatai az előző elméleti fejezetben ismertetett fejlődési modell 6 szintje alapján szerveződnek. Az első szinthez 16 feladat tartozik, ezekkel mérhető a gyermekek számképfelismerése, számok sorrendjének ismerete, valamint a verbális számok és mennyiségek egy az egyhez rendezéssel történő összekapcsolása. A második fejlettségi szinthez 10 feladat tartozik. Itt a számok sorrendjének ismeretét már magasabb számkörökben is vizsgálják, valamint a mentális számegyeneshez kapcsolódó itemek is itt kaptak helyet a tesztben. A feladatok között vannak alacsonyabb számkörben, tárgyakkal végzett kivonási és összeadási műveleteket vizsgáló itemek is (manipulatív számolás) (Fritz, Ehlert, \& Balzer, 2013).

A harmadik szintnél 12 olyan feladattal találkoznak a gyerekek, amelyek annak megértését vizsgálják, hogy a mennyiségek adott számú elemből állnak, továbbá a számegyenes növekvő elemszámú mennyiségeket jelöl. A negyedikhez kapcsolódó 5 feladatnál halmazok és részhalmazok közötti kapcsolatok felismerését, valamint ezek megszámlálását kérjük a gyermekektől. Az utolsó, ötödik szinten tovább 12 feladatot méri a számok és a mennyiségek közötti kapcsolat megértésének magasabb szintjét, amely már a lineáris mentális számegyenes fogalmához kapcsolható. Így itt azt is vizsgáljuk, hogy a gyermek megérti-e a számok közötti távolságot a számegyenesen (Ricken, Fritz, \& Balzer, 2013).

A MARKO-D-t elsősorban pedagógusok számára készítették, a mérés egyesével, szemtől-szemben zajlik. A tesztleírás szerint annak felvétele nagyjából 20-30 percet vesz igénybe. A teszt érdekessége, hogy a kisgyermekek figyelmének fenntartása érdekében a feladatokat egy illusztrált, mesés keretbe ágyazták. A feladatokhoz készített illusztrációkat (erdő, fák), a manipulatív feladatvégzéshez szükséges korongok (mogyorók), a feladatok szövegezését, mind Ben és Lisa mókusokkal kapcsolatosan alakították ki (lásd: 4. ábra). A vizsgálathoz szükséges eszközöket a teszt doboza tartalmazza, a teszt teljes menetét egy összefüzött feladatlapokból álló füzet határozza meg, amelyet az asztalra a gyermek és a mérőbiztos közé felállítva helyezünk el. A füzet tábláit sorban lapozzuk végig, ahogy haladunk 
előre a feladatokkal, ez idő alatt a gyermek a táblán a feladat illusztrációját látja, miközben a mérőbiztos a feladat rövid leírását és a gyerekhez intézett instrukciót, kérdést olvashatja le. Amikor a feladathoz nem kapcsolódik illusztráció, például a tárgyakkal végzett manipulatív számolási feladatoknál, a táblán a gyermek csak egy üres oldalt lát. A tesztcsomagban találhatóak még a feladatokhoz szükséges laminált lapok, különböző színű korongok, és természetesen egy részletes tesztleírás is (Ricken, Fritz, \& Balzer, 2013).

A MARKO-D teszt megbízhatóságát a Rasch-elemzéssel ellenőrizték az eszköz személy szeparációs reliabilitása 0,934, az EAP/PV reliabilitás értéke 0,927 (Langhorst, Ehlert, \& Fritz, 2016). A kidolgozott mérőeszközt főként német óvodapedagógusok használják, kidolgozásakor egy hozzá kapcsolódó óvodai fejlesztési programtervet is kidolgoztak, amellyel együtt hatékony eszköznek bizonyult az óvodákban (Ehlert \& Fritz, 2013). Emellett kutatási céllal is találkozhatunk vele különböző matematikai tartalmú fejlesztőprogramok hatékonyságának bemérésekor (Langhorst, Ehlert, \& Fritz, 2016)

\section{DIFER - Elemi számolási készség teszt}

Hazánkban a gyermekek iskolakészültségének megállapításának egyik legelterjedtebb eszköze a DIFER (Diagnosztikus fejlődésvizsgáló rendszer). A Nagy József és munkatársai (2004b) által megalkotott tesztbattéria országosan ismert óvodapedagógusok és tanítók körében (Apró, 2013). A tesztrendszer kidolgozása már a 70-es években megkezdődött, előzménye a szintén Nagy (1987) által kidolgozott PREFER teszt (Preventív fejlettségvizsgáló rendszer) volt, és már abban a tesztben is fontos szerepe volt a számolás vizsgálatának, amely később a DIFER programcsomagban szereplő elemi alapkészségek mérésére szolgáló tesztek között is helyet kapott kisebb átdolgozást követően elemi számolási készség teszt elnevezéssel, a beszédhanghallás, írásmozgás-koordináció, relációszókincs, tapasztalati következtetés, tapasztalati összefüggés-megértés és szocialitás tesztek mellett (Nagy et al, 2004b).

A DIFER elemi számolási készség tesztjének kialakítása a PREFER-ben is megjelenő struktúrát követi, négy fő részből áll, melyek közül az első a számlálást, második a müveletvégzést pálcikákkal, a harmadik a számképfelismerést és a negyedik rész a számolvasást méri (Nagy, 1987; Nagy et al., 2014b).

A számlálás három részterületre oszlik, melyek közül először az 1-21-ig számolást mérjük, ezt követi a számkörök átlépése kezdve a 30-as számkörrel, majd pedig sorban a 40es, 50-es, 100-as és 500-as számkör átlépését vizsgáljuk. A számlálás harmadik részterületében a visszafelé számlálást nézzük, ebben az esetben is egyre növekvő számkörökön belül. Az első 
három item a 10-es számkörön belül, majd az előző részhez hasonlóan egyre magasabb számkörök visszafelé történő átlépését kérjük, sorban a 10-es, 20-as, 50-es, 100-as és 500-as számkörökkel. A feladatokban a méröbiztos által elkezdett számsor folytatását kérjük, például az instrukció szerint: „Most úgy számolunk, hogy én elkezdem és te folytatod! 26, 27, 28, folytasd!', és akkor adunk pontot, amennyiben a gyermek helyesen folytatta a számolást (Nagy et al., 2014a).

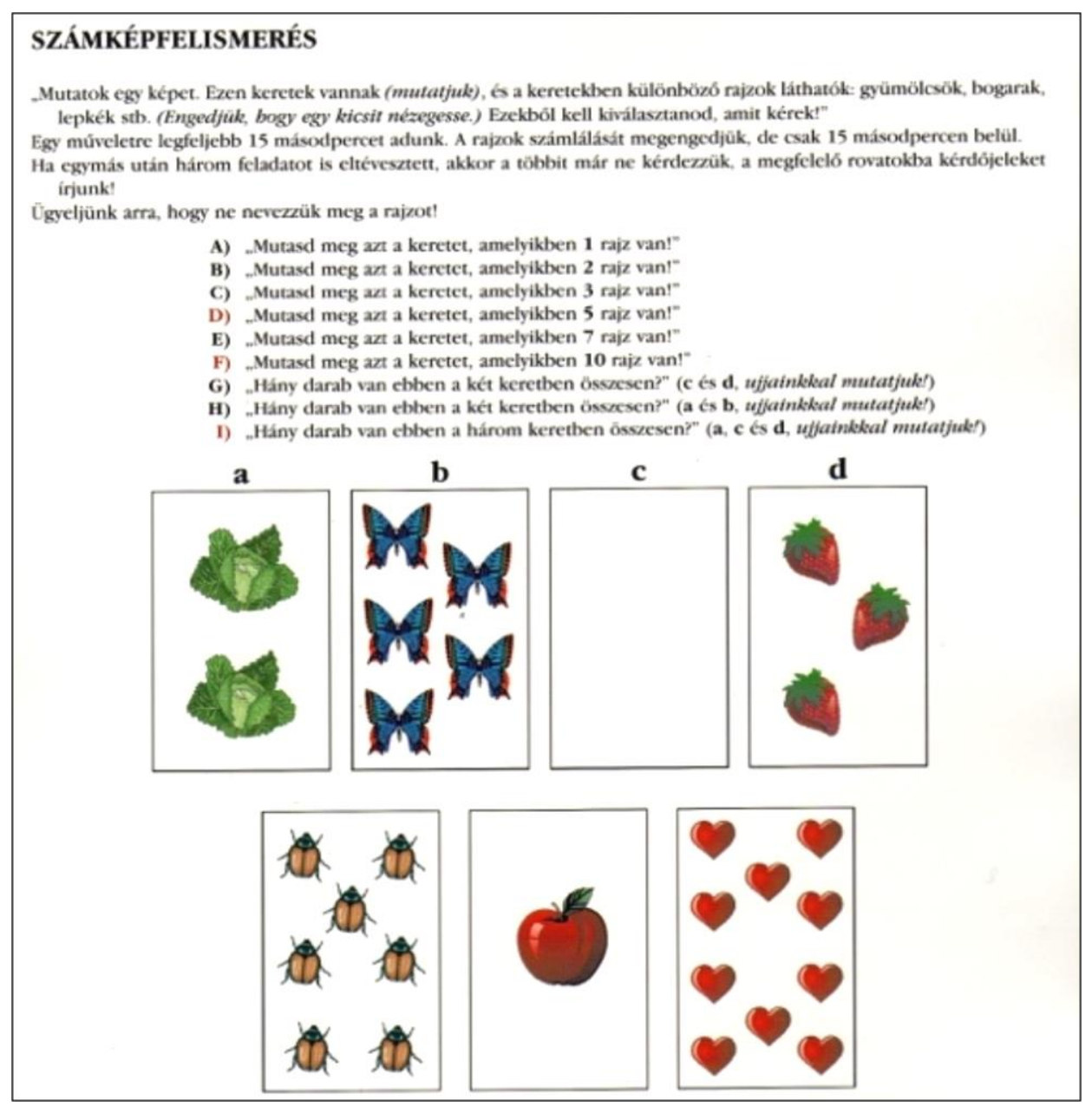

5. ábra

Számképfelismerés részteszt feladatai a DIFER Elemi számolási készség tesztböl (Nagy et al., 2014b)

A műveletek pálcikákkal tesztrészben Nagy és munkatársai (2004a) által leírtak szerint a húszas számkörön belüli manipulatív számolás készségének öt müvelete mérhető. A 11 itemből álló feladatsor első, egyben legkönnyebb müveleteinél, a kiszámlálásnál adott mennyiséget kell a halmazból elvenni. A hozzászámlálás feladatai a halmaz elemszámának növelését kérik. Az elvétel művelete az ismert elemszámú halmaz elemeinek csökkentése a megadott mennyiségig. A bontás feladatainál egyenlő mennyiségű részhalmazok képzését 
kérjük a gyermektől. Végül a csoportosítás müveleténél pedig a meghatározott rendezési elv szerint kérjük részhalmazokból új részhalmazok kialakítását.

A számképfelismerés feladatai alkotják a teszt következő részét (5. ábra), amelyben a tárgyak számosságára vonatkozó itemek kaptak helyet, összesen 9 darab. Ezeknél a feladatoknál tízes számkörök belül kell adott mennyiségeket a gyermekeknek felismerni. A feladatokhoz a laminált lapon szereplő hét ábra szükséges, a gyermekek a válaszaikat adott képre (kártyára) mutatva adják meg. Továbbá az utolsó három feladatban a mérőbiztos mutat adott ábrákra, és kéri a gyermektől, hogy nevezzék meg, mennyi rajzot látnak azokban összesen. A teszt felvételekor a képek megszámolása is megengedett, a válaszadásra legfeljebb 15 másodperc áll rendelkezésre (Nagy et al., 2004b).

Számolvasás mérésére szolgál a teszt utolsó része, amely 4 itemből áll. Ezekben a feladatokban a gyermek elé ismét a laminált lap elhelyezése szükséges, amelynek alján keretekben arab számokat látnak. A feladatokban 10-es, 100-as, 1000-es számkörön belüli számokat kell felismerniük és hangosan leolvasniuk. Egy-egy itemhez két szám tartozik (Nagy et al., 2004a).

Az elemi számolási készség teszt felvétele nagyjából 10-20 percet vesz igénybe. A teszt adminisztrálásához a gyermek Fejlődési mutatója szükséges, amelyben a mérőbiztos lehetőleg a gyermek látószögén kívül rögzíti az eredményeket. A gyermek és a méröbiztos között a tesztbattériában szereplő laminált lapot helyezzük el, amelyről fel tudjuk olvasni a pontosan követendő instrukciókat. A laminált lapon szereplő feladatokon sorban haladunk végig, azt a számképfelismerés és a számolvasás feladatainál fordítjuk a gyermek felé, hiszen akkor az ott megjelenő képek, illetve számok szükségesek a válaszadáshoz. A müveletek pálcikákkal tesztrész neve is emlékeztet egy további eszköz előkészítésére, a 20 db egyszínü pálcikára, amely segítségével tudjuk a manipulatív számolási műveleteket vizsgálni (Nagy et al., 2014a).

Mivel a tesztrészek egyre nehezedő formában vannak kialakítva, így lehetőség van a differenciálásra, illetve rövidítésre gyengébb teljesítményű gyermekek mérésénél, nem szükséges feleslegesen időt tölteni a túl nehéz feladatokkal. A 21-ig történő számolásnál az első tévesztést követően leállíthatjuk a gyermeket, a többi feladatrésznél is hasonlóan, ha egymást követően kétszer sem tudja helyesen folytatni a számolást, nem tudja kirakni pálcikával az adott mennyiséget, vagy nem a megfelelő képre mutat rá, akkor a soron következő harmadik feladattal már nem szükséges terhelni, a teszt leírása alapján ugorhatunk a következő tesztrészre. A kihagyott feladatokra ebben az esetben értelemszerüen nem adhatunk pontot (Nagy et al., 2014a). 
Az elemi számolási készség fejlődését, az erre vonatkozó alfejezetünkben a DIFERteszt bemérésekor végzett nagymintás vizsgálatok eredményei alapján részletesen is ismertetjük. A teszt megbízhatósága az első méréseken magas volt (Cronbach- $\alpha=0,915$ ) (Józsa, 2004). Az eszközzel létrehozása óta sok neveléstudományi kutatásban találkozhattunk, többször is alkalmazták longitudinális vizsgálatoknál iskolai bemeneti méréskor (Józsa, 2004; Csapó, 2014), az elemi alapkészségek más területekkel való összefüggés-vizsgálataihoz (Janurik \& Józsa, 2014; Asztalos \& Rausch, 2014), valamint óvodai és iskolai fejlesztőprogramok hatékonyságvizsgálataihoz (Józsa \& Zentai, 2007; Rausch \& Turainé Toldi, 2016). Azonban országos ismertségére főként a pedagógiai gyakorlatban való alkalmazása által tett szert. Több, mint tíz éve óvodában és iskolában is széleskörben alkalmazzák pedagógusok, fejlesztőpedagógusok gyermekek elemi alapkészségeinek, köztük az elemi számolási készség felmérésére (Apró, 2013).

\subsection{Az eszközök jellemzőinek összehasonlítása}

A bemutatott eszközöket hazai és nemzetközi viszonylatban egyaránt alkalmazzák gyakorló pedagógusok, neveléstudományi és pszichológiai kutatók. Mivel magas reliabilitással rendelkeznek, a mindennapi pedagógiai gyakorlat mellett, kutatásokban összefüggések feltárásánál, fejlesztőkísérletek hatékonyságának vizsgálatánál is használatosak. Röviden összefoglaljuk, hogy a tesztek milyen pszichometriai és általános jellemzőkkel bírnak. Az eszközök fő jellemzőit, résztesztjeiket, itemek számát, és a tesztfelvétel becsült időtartamát, az 1. táblázatban összesítettük.

Mivel gyakori kutatási eszköz, a legrészletesebb eredmények az ENT teszt pszichometriai jellemzőiről állnak rendelkezésünkre, megbízhatósága és érvényessége egyaránt magas, konstruktum-validitását több vizsgálatban is igazolták (Van de Rijt, Van Luit és Pennings, 1999; Aunio \& Niemivirta, 2010). A WENT, a MARKO-D és a DIFER elemi számolási készség teszt reliabilitását is ellenőrizték már különböző vizsgálatokban (Wright, 2013; Ricken, Fritz, \& Balzer, 2013; Józsa, 2004), azonban konstruktum-validitásukról nincsenek empirikus adataink.

Bár megbízhatóan mérik e készségeket, mégis hátrányuk, hogy szemtől szembeni adatfelvételhez kötöttek, nagyobb csoportok felmérése, a mérés adminisztrálása rengeteg időt és energiát vesz el a pedagógusoktól és a kutatóktól. Mint az 1. Táblázatban látható, a DIFER elemi számolás teszt a maga 38 itemével a legrövidebb, de így is 5-25 perc egy gyermek felmérése, a vizsgált eszközök közül a WENT becsült időtartama a legmagasabb, a teljes teszt adminisztrálása közel egy teljes órát vesz igénybe. 
1. táblázat. A vizsgált számolási készségeket mérö tesztek fö jellemzői

\begin{tabular}{|c|c|c|c|c|c|}
\hline Teszt & Részek & $\begin{array}{l}\text { Itemek } \\
\text { száma }\end{array}$ & $\begin{array}{l}\text { Időtartam } \\
\text { (perc) }\end{array}$ & $\begin{array}{l}\text { Életkor } \\
\text { (év) }\end{array}$ & Hivatkozás \\
\hline ENT & $\begin{array}{l}\text { Mennyiség-összehasonlítás, } \\
\text { Csoportosítás, Egy az egyhez } \\
\text { rendelés, Sorba rendezése, } \\
\text { Számnevek használata, } \\
\text { Strukturált számlálás, } \\
\text { Rezultatív számlálás, Számok } \\
\text { általános ismerete }\end{array}$ & 40 & 30 & $4-7$ & $\begin{array}{c}\text { Van Luit et al., } \\
1994\end{array}$ \\
\hline WENT & $\begin{array}{l}\text { Számlálás (előre, vissza), } \\
\text { Arab szám felismerés, } \\
\text { Számolási műveletek, } \\
\text { Számok konstruálása, } \\
\text { Helyi értékek }\end{array}$ & $114^{*}$ & $50-60$ & $4-8$ & $\begin{array}{l}\text { Wright, Martland, } \\
\text { \& Stafford, } 2006\end{array}$ \\
\hline MARKO-D & $\begin{array}{c}\text { Számfogalom, } \\
\text { Aritmetikai készségek } \\
\text { (5 szint) }\end{array}$ & 55 & $20-30$ & $4-6,5$ & $\begin{array}{l}\text { Ricken, Fritz, \& } \\
\text { Balzer, } 2013\end{array}$ \\
\hline $\begin{array}{l}\text { DIFER } \\
\text { ESZK }\end{array}$ & $\begin{array}{c}\text { Számlálás, } \\
\text { Manipulatív számolás, } \\
\text { Számképfelismerés, } \\
\text { Számolvasás }\end{array}$ & 38 & $15-25$ & $4-8$ & $\begin{array}{l}\text { Nagy, Józsa, } \\
\text { Vidákovich, \& } \\
\text { Fazekasné } \\
\text { Fenyvesi, 2004b }\end{array}$ \\
\hline
\end{tabular}

Megjegyzés. * Nem lineáris teszt, fejlettségi szintek szerinti tesztrészekből és feladatokból tevődik össze.

Az instrukciók és illusztrációk tekintetében jelentős eltérések vannak az eszközök között. Igaz, alapvetően mindegyik eszköznél törekszenek arra, hogy a kérdések legalább egy része valamilyen kisgyermekhez közelebb álló tartalommal legyen megtöltve, ezek mértéke változó. A WENT és DIFER tesztekben van a legkevesebb illusztráció, elsősorban interjús kikérdezésre hagyatkoznak, emellett egyes számolási feladatokat a gyermek korongokkal vagy színes pálcikákkal oldhat meg, egyszerübb illusztrációt a számképfelismerés feladatinál láthatunk. Az ENT ennél egy fokkal több illusztrációt tartalmaz, a mérőeszköz feladatainak jelentős része a gyermek elé helyezett feladatlapokra épül, és egyes itemeknél a gyermeket bizonyos rajzok összekötésére is kérjük, a kérdésekben és az illusztrációkban is megjelennek gyerekközeli tartalmak (pl. üveggolyók, kacsák). A legmagasabb szinten a MARKO-D illusztrációi vannak kidolgozva. A mérést a gyermek figyelmének fenntartása érdekében illusztrálták, és egységes kerettörténetbe helyezték, a feladatokban a mókusokkal kapcsolatos 
tartalmak kerülnek elő, nézik a csillagokat, meg kell számolni a mogyorókat, stb. Az illusztrációk a feladatokhoz kapcsolódnak, így felesleges figyelemelterelés nem érzékelhető. A német kutatók által kidolgozott eszköz jó példa a nemzetközi gyakorlatból a körültekintően megtervezett, gyerekekhez közel álló módon illusztrált és kerettörténetet is alkalmazó kisgyermekkori mérőeszközre.

\section{3. Összefoglalás}

A fejezetben bemutattuk a korai numerikus készségek mérésének lehetőségeit. Részletesen négy pedagógusok és pedagógiai kutatók által a mai napig széles körben alkalmazott mérőeszközt ismertettünk, amelyek közül Magyarországon a DIFER Elemi számolási készség tesztje a legelterjedtebb. Áttekintettük az eszközök résztesztjeit, egyes összetevőit, speciális jellemzőit, amiket az előző alfejezetben össze is vetettünk. Tekintve, hogy a számolási készségek mérése fontos eleme a korai pedagógiai fejlesztő munkának, ezek a tesztek szervesen kapcsolódnak a következő fejezetben bemutatott fejlődési modellekhez, így a fejlődési modell és mérőeszköz párosához gyakran fejlesztőeszközök is társulnak, azonban a pedagógusok ezek nélkül is be tudják építeni a vizsgálatok eredményeit az óvodai vagy iskolai matematikai nevelési foglalkozásokba. A mérés-értékelési eszközök által nyújtott információk nélkül nehéz lenne a gyermekek képességszintjéhez igazodva megtervezni a tanulócsoportban végzett nevelömunkát, amelynek természetesen a tantervekben meghatározott keretek között kell zajlani, valamint a későbbi matematikatanulást kell szolgálnia. A fejlődési modelleket bemutató fejezetet követően ezt a témakört járjuk körül.

\section{FEJLŐDÉSI MODELLEK A KORAI NUMERIKUS FEJLŐDÉS LEÍRÁSÁRA}

\subsection{Fejlődési modellek}

A kisgyermekkori numerikus fejlődés leírására több modell is rendelkezésünkre áll, amelyek egy része különböző készségek párhuzamos fejlődését és összekapcsolódását (Aunio \& Räsänen, 2016), más modellek tudáselemek és tapasztalatok egymásra épülését helyezik előtérbe (Fritz, Ehlert, \& Balzer, 2013). Ebben a fejezetben három fejlődési modellt ismertetünk és összegzünk, a modellek mindegyike az óvoda-iskola átmenet időszakának numerikus készségeinek fejlődését írja le, megmutatjuk hasonló pontjaikat és rávilágítunk az esetleges eltéréseikre, továbbá bemutatjuk a fejlődési modellekhez kapcsolódó vizsgálatok főbb empirikus eredményeit. 


\section{Alapvető számolási készségek - Az iskolai matematikatanulás elöfeltételei}

Az Aunio és Räsänen (2016) által készített alapvető számolási készségek modellje azoknak a legfontosabb számolási készségeknek az egybegyüjtését célozta meg, amelyek kulcsszerepet töltenek be a matematikai készségek fejlödésében. Ezeket az összetevőket négy fö csoportba sorolták, ugyanakkor a csoportok közötti összekapcsolódás is fontos része elméletüknek. A modellt elsősorban 5-8 éves kisgyermekek matematikai fejlesztésével foglalkozó szakemberek számára dolgozták ki, és annak felépítését, összetevőinek meghatározását több longitudinális kutatás eredményeire alapozták (Aunola, Leskinen, Lerkkanen, \& Nurmi, 2004; Jordan, Glutting, \& Ramineni 2010; Aunio \& Niemivirta 2010; Desoete, Stock, Schepens, Baeyens, \& Roeyers, 2009).

Aunio és Räsänen (2016) első csoportként a szimbolikus és nem-szimbolikus számérzéket határozták meg, amely hatással van a többi csoportban megjelenő összetevők jelentős részére. A korai numerikus készségek vizsgálati eljárásainál gyakran megjelenő feladatokban mutatnak rövid időre különféle halmazokat, mintázatokat a gyermekeknek, amelyek mennyiségét gyorsan kell tudniuk megnevezni. Ezek gyakran a szubitizáció, mintázatok felismerése, mennyiségek gyors összehasonlítása nevet viselik. A számérzékről fejezetünk elején már írtunk, és bemutattuk ehhez kapcsolódva Dehaene (2003) hármas kódolás elméletét is. A szubitizáció fogalma is ehhez a területhez kapcsolható, a fogalmat pszichológiai témájú szakirodalomban régóta alkalmazzák, aminek lényege kis mennyiségek azonnali észlelése, felfogása (Fuson, 1992). Már az ezzel foglalkozó korai vizsgálatok is kimutatták, hogy az öt éves gyermekek és a felnőttek ugyanolyan gyorsan ismerik fel az egy, kettő, három és négy elemü halmazokat. A szubitizáció fejlődésével kapcsolatosan Starkey és Cooper (1995) végeztek feltáró vizsgálatot, amelyben a különböző elemszámú halmazokat 200 milliszekundum időtartamig mutatták fel a vizsgálati személyeknek, így biztosítva, hogy ne legyen lehetőségük azokat megszámolni. Már a kétéves gyermekek is képesek voltak 1-3 elem felismerésére, a háromévesek 1-4 elem számát tudták megnevezni, a négy és öt éves gyermekek képesek voltak 1-5 elemü halmazok mennyiségét megállapítani megszámlálás nélkül. Ennek megértése azért lényeges, mert kisgyermekeknél így kisebb elemszámú halmazok mennyiségének megállapításánál, vagy két kisebb mennyiségü halmaz elemszámának összehasonlításánál a megszámlálás és annak eljárásai nem feltétlenül játszanak szerepet. 


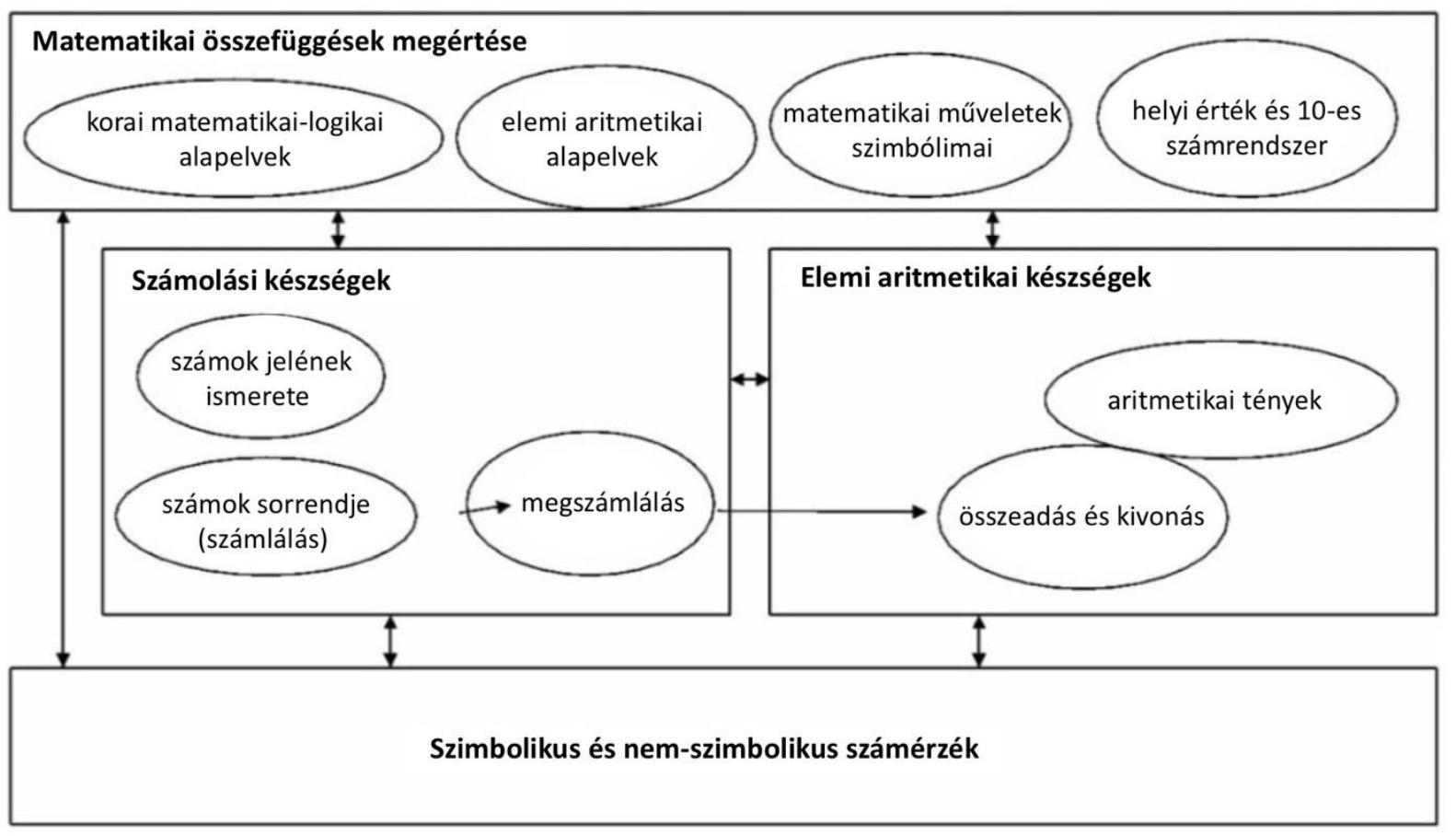

6. ábra

Alapvető számolási készségek a matematika tanulásához 5-8 éves gyermekeknél (Forrás: Aunio \& Räsänen, 2016, p. 16)

A soron következő csoportot a matematikai összefüggések megértéseként nevezték el, ebben azokat a számolás fejlődésében meghatározó elemeket foglalják egybe, amelyek a halmazok elemei közötti mennyiségi és nem mennyiségi (például: szín, forma) kapcsolatok felismeréséhez, megértéséhez kötődnek. Ezek az összetevők abban is szerepet játszanak, hogy a tanulók helyesen használják a matematikai szimbólumokat (például: relációjelek), továbbá a korai matematikai eljárásokat is ide sorolták. Ide tartoznak azok a számolási módszerek, amiket az óvodai matematikai nevelés során tapasztalnak meg a gyermekek, ezek a soralkotás, csoportosítás és az egy az egyhez rendelések feladatai. A soralkotás, szerializáció különösen fontos a számok sorrendjének, az elemi számolás megtanulásához. A még ebben a csoportban helyet kapó elemi aritmetikai eljárások megismerése is alapvető az iskolai matematikatanuláshoz, a rész-egész viszonyok megértése, az összeadás és elvétel müveletei tartozhatnak ide (Aunio \& Räsänen, 2016).

A következő csoportban helyezkednek el a számolási készségek. Aunio és Räsänen (2016) ebbe a halmazba sorolják a számnevek sorrendjét (number word sequence), hazai szakirodalomban jobban ismert nevén, számlálást, amelybe beleértjük a pozitív egész számok előrefelé és visszafelé történő helyes felsorolását, magasabb fejlettségi szinten pedig nem csak nagyobb számkörök átlépését, hanem a kettesével, ötösével vagy tízesével történő számolást is. Másik fontos alkotóeleme ennek a csoportnak a megszámlálás, adott halmaz mennyiségének 
megállapítása az elemek összeszámolásával. Itt a gyermekek a megtanult számneveket és azok helyes sorrendjét használják fel a helyes válasz megadásához, így nem a korábban bemutatott szubitizációról beszélünk. A megszámlálás fejlődéséhez három összetevő együttes elsajátítására van szükség (Sarnecka \& Carey, 2008), az egy az egyhez megfeleltetés, a számnevek helyes sorrendjének ismeretére, valamint a kardinális számok fogalmára, vagyis arra, hogya a gyermekek megértsék, az utolsónak kimondott szám jelenti a halmaz elemeinek összességét (Aunio \& Räsänen, 2016).

Az utolsó csoportban az alapvető aritmetikai készségek szerepelnek, ide a modell szerzői a számok jelével, arab számokkal végzett alapvető számolási műveleteket, az összeadást és kivonást sorolják. Így ez a terület már az iskolás korcsoportban kerül elő, fontos előfeltétele az arab számok felismerése és a számolvasás készségének stabil fejlettsége is (Aunio \& Räsänen, 2016).

A modellben bemutatott számolási készségek fejlődését az elmúlt évtizedekben többen is vizsgálták, ezek túlnyomó része keresztmetszeti vizsgálat és elsősorban az óvoda időszakára vonatkozik (Aunio et al., 2006). Részletesebben egy longitudinális vizsgálat eredményeit ismertetjük, amelyet Jordan és munkatársai (2006) végeztek. Kutatásukban összesen 441 gyermeket követtek nyomon az iskolaelőkészítő évben, ami a hazai köznevelés óvodai nagycsoportjának felel meg. Az első mérési időpont szeptemberben, ezt követően novemberben, februárban és áprilisban voltak további mérések. A gyermekek átlagosan 5 év 7 hónapos életkorúak voltak a vizsgálat kezdetén (Jordan, Kaplan, Oláh, \& Locuniak, 2006).

A vizsgálatba bevont numerikus összetevők, a számérzék, számolási készségek, arab számok felismerése és számlálás fejlődése egyenletes volt ebben az időszakban. A vizsgálat egy célja arra irányult, hogy feltárja, van-e jelentős eltérés az alacsony és a közepes szociökonómiai státuszú gyermekek fejlődésében, illetve a nemek közötti eltéréseket is kielemezték (7. ábra). Növekedési modellezést (growth curve modeling) alkalmazva egyenletes lineáris fejlődést mutattak ki a vizsgált periódus alatt. Azok a tanulók, akik az iskolaelőkészítés időszakát alacsonyabb fejlettségi szinten kezdték, magasabb ütemben fejlődtek. Vizsgálatuk fontos eredménye, hogy az alacsony szoci-ökonómiai státuszú gyermekek fejlődésének mértéke elmaradt a jobb szociális helyzetü társaiktól. A nemek között összehasonlítás pedig a fiúk magasabb teljesítményét mutatta ki. 
Számérzék

(Number sense)

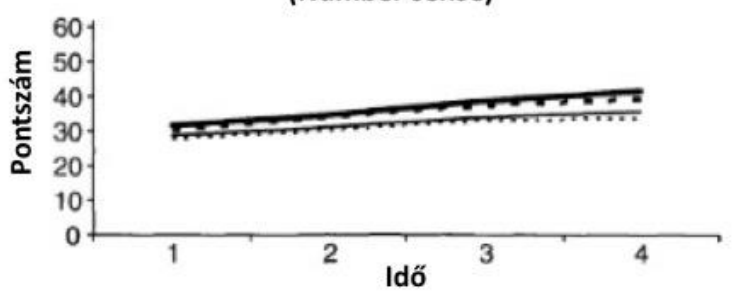

Arab számok felismerése
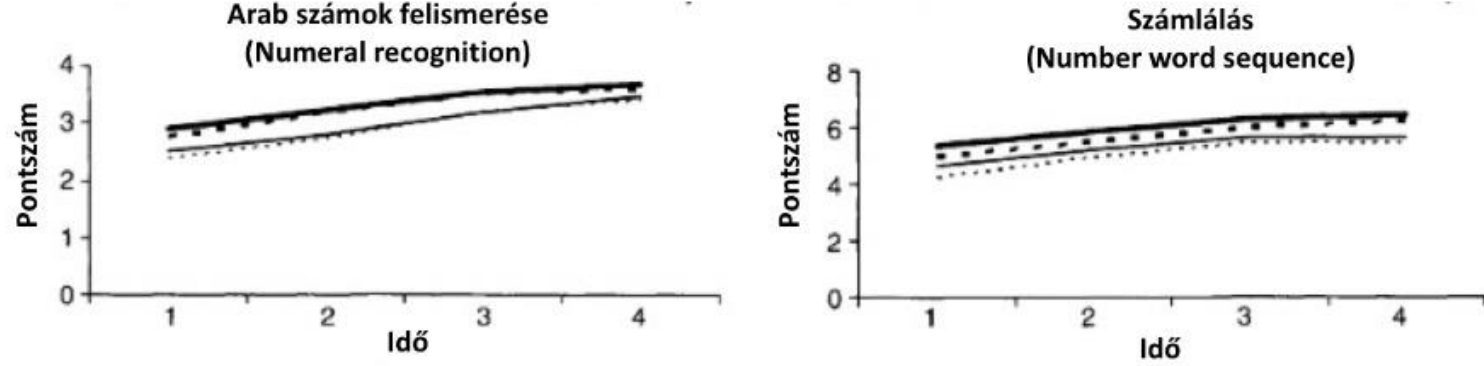

...... Lányok (Alacsony)

... Lányok (Közepes)

7. ábra

A korai numerikus készségek egyes összetevőinek fejlödése 5-6 éves korban (Jordan, Kaplan, Oláh, \& Locuniak, 2006, p. 164 alapján)

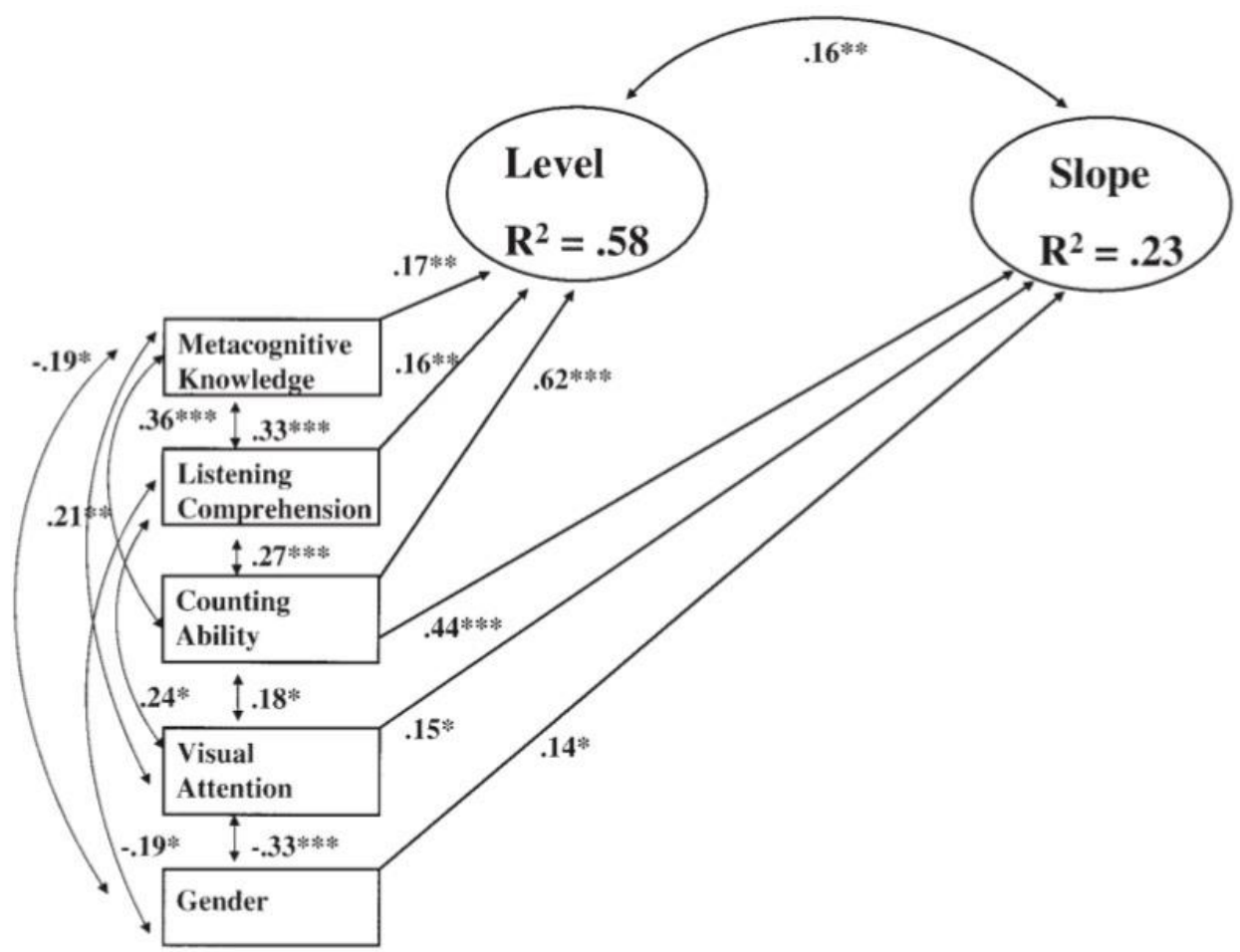

8. ábra

Az iskolai matematikateljesitmény szintjét és változását elörejelzö tényezők (standardizált együtthatók, $*_{p}<0,05 ; *^{*} p<0,01, * * * p<0,001$ )

(Forrás: Aunola, Leskinen, Lerkkanen, \& Nurmi, 2004, p. 704) 
A bemutatott mérés mellett, Aunio és Räsänen modelljéhez fontos alapot szolgáltatott Aunola és munkatársainak (2004) longitudinális vizsgálata is, amelyben számolási készségek mellett különféle kognitív készségek, vizuális figyelem, beszédértés, méta kognitív tudás, valamint a nemek iskolai matematikai teljesítményre gyakorolt hatását elemezték (8. ábra). A kutatásban látens növekedési modellezést (latent growth curve modeling) alkalmaztak, amelynek segítségével feltárták, hogy a matematika teljesítmény szintjére és növekedésére milyen mértékű hatást gyakorolnak az előbb felsorolt tényezők. Mintájukat az iskola első három évfolyamán követték nyomon, amelyből kiderült, hogy a legerősebb hatást a számolási készségek gyakorolják mind a matematika teljesítmény szintjére, ahogyan a három év alatt végbemenő fejlődésre is. A többi vizsgálatba bevont változó esetében szignifikáns, de jóval alacsonyabb regressziós együtthatókat mértek.

\section{Egy 6-szintü matematikai kompetenciamodell}

Fritz, Ehlert és Balzer (2013) a fejezetünk elején bemutatott numerikus megismerés elméleteire, közöttük a számérzék és a tárgyállandóság fogalmaira alapozva hozta létre saját hat fejlődési lépcsőből álló korai matematikai kompetenciamodelljét 4-8 éves gyermekek számolási készségeinek fejlődésének leírására. A modellben minden fejlődési szintet egy bizonyos, jól körülhatárolható matematikai tudáselem, matematikai fogalom megértése jellemez, ilyen például a kardinális számok fogalma, vagy a mentális számegyenes fejlődése, amelyeket az előző bekezdésekben részletesen is tárgyaltunk.

Fritz, Ehlert és Balzer (2013) tanulmánya szerint a modell első, számlálás elnevezésű szintjén gyermekek alacsonyabb számkörökben megtanulják a számneveket, és kisebb mennyiségeket hangosan is meg tudnak számolni. Azonban a számolást csak egytől tudják elkezdeni, és még nem alakult ki bennük a kardinális számok fogalma, így ha 5 tárgyat kérünk tőlük, még nem képesek azt odaadni. Az ezt követő, második szintet a szerzők a mentális számegyenes fejlődésével kapcsolják össze. Ezt megelőzően a kicsik már fel tudják sorolni az egymást követő számneveket, ám az ezek közötti kapcsolat még csak kezdetleges. Ennek a szintnek a végére azonban a gyermekek ismerik az egyes számok közötti viszonyokat a számsorban elfoglalt helyük alapján. Tudják, hogy az öt nagyobb a négynél, azonban a mentális számegyes lépcsőfokai még korántsem lineárisak. A kisebb számok egymáshoz való viszonyát azok távolságát viszonylag pontosan meg tudják határozni, viszont magasabb számkörökben ugyanez már nehézséget jelent. Ez a számegyes ekkor még csak egyfajta ordinális skálaként 
jellemezhető. A szerzők a harmadik fejlődési lépcsőre helyezik a kardinalitást és bontást, amelynek legfontosabb jellemzője, hogy a gyermekek már képesek azonosítani az utolsónak kimondott számnevet a halmaz elemeinek számával, amely fontos előfeltétele a hatékony számolási stratégiák kialakulásának, és megalapoz minden további fejlődési szintet. A bontás azért jelenik meg a szintben, mert a kardinalitás koncepcióján belül lényeges annak megértése is, hogy az adott halmaz részhalmazokra bontható és újra összerakható, az elemek száma ettől még nem változik. Ennek a koncepciónak tovább fejlődésével jutunk el a modell negyedik fejlődési szintjére, ahol gyermekek számára világossá válik, hogy minden szám egy bizonyos mennyiséget jelöl, ismerik a rész-rész-egész sémákat, melyekből, ha kettőt megadunk, ki tudják következtetni a harmadikat. Továbbá a fejlődésnek ezen a szintjén lépnek be az arab számok, amelyek később különösen fontos részét képezik a gyermekek korai matematikai kompetenciájának. Az ötödik fejlődési szint a relációk szintje, ebben a kardinalitás, és sorrendiség fogalmának megértése összekapcsolódik és a tanulók mentális számegyenes fogalma kezd lineárissá válni. Végül, a hatodik szinten a tanulók megtanulják a különféle matematikai összefüggéseket, szabályokat, ismerik az arab számok rendszerét, alapmüveletek jeleit, és az eddig felsorolt koncepciókat, tudáselemeket együttesen tudják alkalmazni (Fritz, Ehlert és Balzer, 2013).

Az ismertetett fejlődési modellhez készült egy diagnosztikus mérőeszköz 4-8 éves gyermekek számára, a MARKO-D teszt (Ricken, Fritz, \& Balzer, 2013), amelyet a következő alfejezetben részletesen is bemutatunk. Az eszközzel ellenőrizték és empirikusan igazolták a modell szintjeit és a 4-8 éves gyermekek szinteken elfoglalt helyét. Továbbá a fejlődési modell és a mérőeszköz mellé készült egy játékos matematikai fejlesztőprogramcsomag is, ez a Mina és a vakond, amelyet Németországban hatékonyan alkalmaztak a MARKO-D teszttel azonosított, lemaradásban lévő gyermekek felzárkóztatására. A 2014-ben a fejlesztőeszköz hazai adaptációjára is sor került (Rausch, Debreczeni, \& Szabó, 2014; Rausch \& Turiané Toldi, 2015).

\section{Az elemi számolási készség fejlődése}

Hazánkban a DIFER tesztbattéria (Diagnosztikus Fejlődésvizsgáló Rendszer) kidolgozásakor részletesen vizsgálták az elemi alapkészségek, köztük az elemi számolási készség fejlődését. Nagy és munkatársai (2004a) az elemi számolási készséget a százas számkörbeli számlálás, a húszas számkörbeli manipulatív számolás, tízes számkörbeli számképfelismerés és a százas számkörbeli számolvasás készségeiből álló elemi alapkészségként definiálják (Nagy, Józsa, 
Vidákovich, \& Fazekasné Fenyvesi, 2004a). Ebben a fejezetben a készség összetevőinek fejlődését, valamint az ehhez kapcsolódó háttérvizsgálatok főbb eredményeit mutatjuk be.

Józsa Krisztián (2014) a Nagy József DIFER teszthez (Nagy et al., 2004) meghatározott fejlettségi szintekhez kapcsolta az elemi számolási készség egyes alkotóelemeit, amelyek elsajátítását a számkörök folyamatos bővülésével írja le. Az első, előkészítő szinten a gyermekek még az ötös számkörig terjedően rendelkeznek számfogalommal, az ennél magasabb számokat csak mondóka szerüen ismerik. A következő, kezdő szint ugyanezen az elven, de már a tízes számkörig terjed, amit a haladó szinten már a húszas számkörön belüli számolás követ. Az utolsó előtt, befejező fejlettségi szintnél eljutnak a százas számkörben történő számlálásig és a manipulatív számolási müveletek egyes elemeire is képesek már, emellett itt már kezdeti ismeretek is megjelennek a számjegyekről. Végül, az optimum szinten stabil számfogalomról beszélhetünk, az összes összetevőnél képesek a bemutatott számkörökön belüli műveletekre, számképfelismerésre, valamint ötszázas számkörön belül is képesek számolni a gyermekek. Emellett a számjegyek leolvasása sem jelent nekik problémát százas számkörön belül.

Az országos felmérések eredményei alapján az elemi számolási készség fő összetevőinek fejlődését a 9. ábra mutatja. Ezek közül a számlálás fejlődése a legintenzívebb az óvoda időszakában, amelyen belül először a 21-ig számlálás éri el az említett optimum szintet az óvoda végére. A számlálás további összetevői, a számkörök átlépése és a visszafelé számolás is gyorsan fejlődik az óvodás korú a gyermekeknél. Bár minden összetevőnél az látható, hogy a legmeredekebb fejlődés a nagycsoportban tapasztalható. A számképfelismerés területe eleve magasabb szintről indul óvodás korban, és fejlődése emiatt valamivel lassabbnak érzékelhető. Legkésőbb a számkörök átlépése, a visszafelé számolás és a számolvasás éri el a magasabb fejlettségi szinteket. Ha abból indulunk ki, hogy az iskolai matematikatanuláshoz az összetevők többségének ideális esetben el kellene érnie a befejező szintet, akkor láthatjuk, hogy ez a nagy átlag esetében csak második évre következik be. Ezáltal a gyermek jelentős része úgy ül be az iskolapadba, hogy még nem fejlődtek ki teljesen az elemi számolási készségeik, így a tanítónak feltétlenül oda kell figyelnie a számolás elemi összetevőinek fejlesztésére is (Nagy et al., 2004a; Józsa, 2014). 


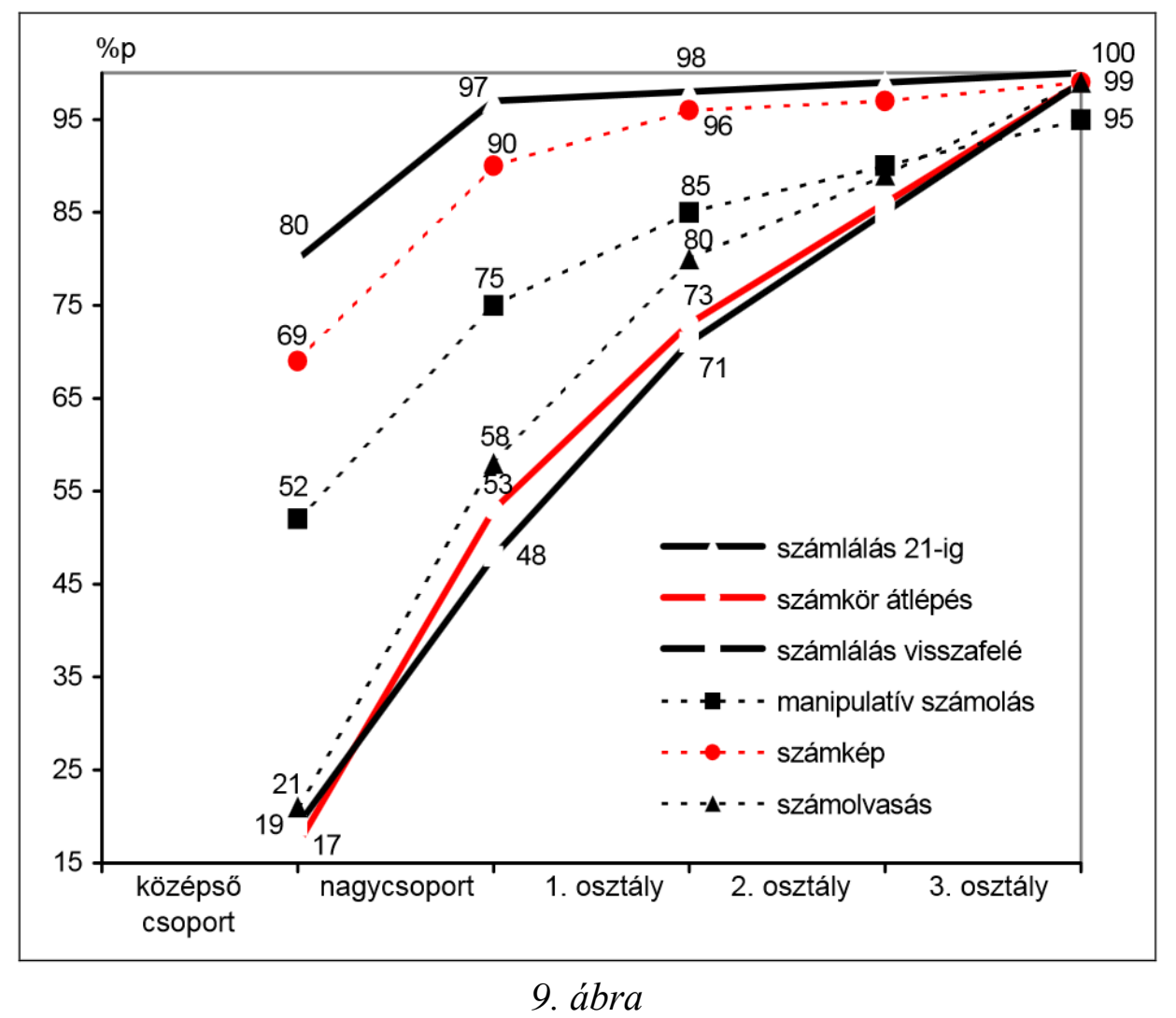

Az elemi számolási készség összetevőinek fejlödése (Nagy et al., 2004a, p. 47)

Amint az eredményeken is látszik, az elemi számolási készség fejlődése hosszú folyamat, most csak az átlagokat mutattuk be, viszont az iskolát kezdő gyerekek között jelentős egyéni különbségek vannak, és már ebből is kivehető, hogy többségük még nem éri el az optimális szintet minden összetevő esetében. A legnagyobb fejlődés az elemi számolás készségének terén a nagycsoportban és az iskola első évfolyama alatt megy végbe. A kiugró különbségek meghatározóak a gyermekek értelmi fejlődése szempontjából, mivel az elemi számolási készség nélkülözhetetlen az eredményes iskolakezdéshez és az iskolai matematikatanuláshoz (Nagy et al., 2004a). Korábbi vizsgálatokból arra is fény derült, hogy a családi háttérnek milyen jelentős szerepe van e készség fejlettségében. Amint azt Józsa is kiemeli, a számolási készségek fejlettségét megvizsgálva a szülők iskolázottságának szintjei szerint, kivehető, hogy jelentős különbségek vannak a szintek között. A legalacsonyabb és legmagasabb iskolai végzettségü szülök első osztályos gyermekeinek teljesítménye között 27 százalékpontnyi különbséget mért. Ha ennek tükrében visszatekintünk a 9. ábrára, akkor kivehető, hogy ez ebben az életkori csoportban az összetevők átlagos fejlődését nézve a különbség egy tanévet is jelenthet (Józsa, 2004; Józsa, 2014). 


\section{2. Összefoglalás}

Ebben a fejezetben a korai numerikus készségek összetevőit és azok fejlődését mutattuk be. Az ismertetett modelleket összegezve elmondhatjuk, hogy a szakirodalomban széleskörben elterjedt nézet szerint a számolási készségek fejlődését megelőzi a mennyiségek hozzávetőleges reprezentációja, a számérzék (Dehaene, 2003; Lipton \& Spelke, 2005). Az ezzel foglalkozó tanulmányok szerint a számérzék már a szimbolikus számreprezentációk előtt megjelenik, és kapcsolatban áll a becsléssel, számolási készségekkel, mennyiségek, halmazok elemeinek összehasonlításával, ezek pedig mind fontos alapjait képezik később az iskolai matematikatanulásnak (Jordan et al., 2007).

A verbális számolási készségek fejlődéséhez először a számok nevét kell elsajátítani. A gyermekek azok sorrendjét is elkezdik megtanulni már öt éves koruk előtt. Tanulmányunkban az elemi számlálásnak nevezett terület, a számok megfelelő sorrendjének ismeretét (előre és visszafelé), számkörök átlépésének rutinjait jelenti, melyek fontos alapjai számolási készségeknek, elemi számolási mủveletek végzésének. Ezek nélkül elképzelhetetlen az összeadás, kivonás megtanulása az iskolában (Aunio \& Räsänen, 2016). A számlálás az egy az egyhez megfeleltetésen, számnevek helyes sorrendjén és a kardinális számok fogalmán alapulva képezi az aritmetikai készségek alapját (Aunio \& Niemivirta, 2010). Az elemi műveletek, számolási feladatok elvégzésének készségei a számok sorrendjének és a kardinalitás fogalmának megértését követően kezdenek gyorsan fejlődni a gyermekeknél (Fritz, Ehlert és Balzer, 2013). Időközben a gyermekek megtanulják a különböző matematikai eljárásokat, szabályokat és összefüggéseket. A korai numerikus készségek szükségesek az iskolai matematika tananyag elsajátításához, a hiányosságukból fakadó problémák hatásait pedig később sokkal nehezebb már kompenzálni (Jordan et al., 2009; Aunio \& Niemivirta, 2010). A számolási készségek fejlődésénél szándékosan nem tértünk ki a számolási készségek zavaraival kapcsolatos vizsgálatok eredményeire, mindössze röviden említettük meg az ehhez is kapcsolódó fogalmak, például a mentális számegyenes és verbális szókeret kapcsolatának jelentőségét. A bemutatott fejlődési modellekhez kapcsolódóan több mérőeszköz is a szakemberek rendelkezésére áll, amelyeket az előző fejezetünkben ismertettünk. 


\section{MATEMATIKA AZ ÓVODÁBAN ÉS AZ ISKOLA KEZDŐ SZAKASZÁBAN}

Ebben a fejezetben az óvodai matematikai nevelés és az általános iskola első két évének matematikatanításának tartalmát tárgyaljuk. Először az óvodai matematikai nevelés fő céljait és módszereit vázoljuk fel, és az óvodáztatás időtartama alatt az iskolai matematikatanulásra felkészítő tevékenységek tartalmi jellemzőit ismertetjük, ezt követően külön részt szentelünk az iskolakészültség fogalmának bemutatására, amin belül a kognitív területek fejlettségére vonatkozó pontokat emeljük ki. Végül ismertetjük az általános iskola alsó tagozatának matematikai tartalmi kereteit, elsősorban az első és második évfolyam tantervi struktúrájára alapozva, ahol nem csak a szaktárgyi területekre, hanem az iskolai első évei alatt tanult matematikai eljárások, ismeretek alkalmazására is kitérünk.

\subsection{A hazai óvodai matematikai nevelés tartalma és az iskolakészültség Az óvodai matematikai nevelés célja, feladatai}

A hazai óvodák müködését és pedagógiai munkáját, az óvodai nevelés általános céljait és feladatait a Köznevelésit Törvény (2011. évi CXC. törvény) 5. § 4. pontja alapján az Óvodai Nevelés Alapprogramja (363/2012. (XII. 17.) Korm. Rendelet) (továbbiakban: ONAP) és az annak megfelelően kidolgozott helyi pedagógiai programok határozzák meg. Az ONAP csak felületesen érinti a matematika nevelés területét, azt mindössze pár alpontban jeleníti meg. A matematikai neveléssel kapcsolatos tartalmak az óvodai élet tevékenységi formái és az óvodapedagógus feladatai című fejezet a külső világ tevékeny megismerésről szóló alfejezetében kerülnek elő. A programban itt a környezet formai, mennyiségi, téri viszonyairól való tapasztalatszerzést említik, amelyet az alfejezet harmadik pontjában leírt matematikai tartalmú tapasztalatszerzés követ: „A gyermek a környezet megismerése során matematikai tartalmú tapasztalatoknak, ismereteknek is birtokába jut és azokat a tevékenységeiben alkalmazza. Felismeri a mennyiségi, alaki, nagyságbeli és téri viszonyokat: alakul itélöképessége, fejlődik tér-, sík- és mennyiségszemlélete.” Az ONAP szövegrészeiben megjelenő más területekkel összehasonlítva, az anyanyelvi és szociális-érzelmi nevelés sokkal hangsúlyosabban, egyben bővebben kifejtve van jelen. Ez jól megragadható az utolsó, a fejlődés jellemzői az óvodáskor végére című fejezet tartalmában is, hiszen itt mindössze az „elemi mennyiségi ismeretei vannak” szövegrészt találjuk, bár az előtte pár bekezdéssel megjelenő, inkább vizuális- és mozgásfejlődésre vonatkozó gondolatok között lévő téri észlelés 
és téri tájékozódás fogalmakba a geometria tanulásának megalapozását is beleérthetjük. Ebből is következik, hogy az előbb bemutatott nagyvonalú keretek között az óvodákra hárul, hogy saját pedagógiai programjukon belül az óvodai matematikai nevelési feladataikat részletesen kidolgozzák. Az óvodai pedagógiai programok jelentős része leképezi az ONAP struktúráját, és sok dokumentum, annak megfelelően, csak mellékes területként foglalkozik a matematikai neveléssel, föként a környezeti nevelés részeként.

\section{Az óvodai matematikai nevelés tartalma}

A jogszabályok és dokumentumok áttekintése mellett megvizsgáltuk a hazai óvodapedagógusképzés óvodai matematikai neveléshez kapcsolódó tematikáit, és a matematikai nevelés tartalmát a leggyakrabban megjelölt hazai szakirodalom (Perlai, 1997; Villányi, 1993; Körmöci, 2014) alapján tárgyaljuk. Ezek alapján három fő egységbe rendezhetjük a matematikai nevelés tartalmát, a számfogalom, a halmazok és a geometria témakörébe.

A halmazok témaköre sok tekintetben átfedést mutat más fejlesztési területekkel. Jellemzően először a megfigyelésre és szókincsbővítésre helyezik a hangsúlyt, annak érdekében, hogy különböző tárgyakat, vagy akár személyeket képesek legyen a gyermekek összehasonlítani, leírni bizonyos tulajdonságaikat, és ezután felismerni az észlelhető azonosságokat és különbözőségeket. Jellemzően ezt követi a halmazképzés megalapozása, amikor az óvodapedagógus kérésére egy adott tulajdonságnak megfelelően tudnak tárgyakat kiválogatni vagy egybegyüjteni. Erre épül az osztályozás begyakorlása, amikor a meghatározott jellemzők szerint kérik a gyermekeket, hogy válogassák szét a halmaz elemeit, így képezve részhalmazokat. Magasabb fejlettségi szinten kezdődik meg a soralkotás, tárgyak meghatározott szempontok szerinti sorba rendezése, ahol együttesen szükséges alkalmazni a már megtanult logikai eljárásokat. Emellett ennél a terültnél a nagycsoportos korosztályhoz tartozó gyermekeket a pedagógus vezeti rá összefüggések felismerésére, és kiemelt szerepet kap a gyermekek beszéltetése, megnevezik a tulajdonságokat, a tevékenységek alatt elmondják mit csinálnak (Perlai, 1997). A jellemző fejlesztő feladatokban már észrevehetők az általános következtetéses gondolkodási képességek műveletei is. Előfordul, hogy megjelennek induktív gondolkodási műveletek (Klauer, 1997), például sorba rendezésnél, vagy részhalmaz képzésnél a gyermekeknek kell felismerni a szabályt, ami alapján folytathatják a megkezdett sort, vagy ami szerint részhalmazokat képezhetnek. 
A számfogalom megalapozása, vagy előkészítése kiemelt feladat az óvodai matematikai nevelésben, jellemzően a halmazok témakörével párhuzamosan van jelen a matematikai tartalmú irányított foglalkozásokon, amelyeken először a gyermekek természetes tapasztalataira építve kezdenek foglalkozni a mennyiségekkel és a számokkal. Kisebb életkorban ez egyszerüen észlelhető tulajdonságok összemérésével kezdődik. A gyerekek játékos keretek között mérik össze adott tárgyak hosszúságát, méretét, térfogatát és tömegét. Ezt követi a halmazok mennyiségének összemérése, ahol fokozatosan szereznek tapasztalatot a halmazok elemeinek számosságáról, és a kardinális számok fogalmát is megértik. Ezzel párhuzamosan a tőszámok és sorszámok neveit is megtanulják, számláláskor azokat megfelelő sorrendben alkalmazzák, és meghatározott számolási műveleteknél ezeket helyesen tudják alkalmazni. A számneveket pontosan össze tudják kapcsolják a mennyiségek változásaival (Perlai, 1997; Körmöci, 2014).

A geometria tanulásának megalapozása is hangsúlyosan jelenik meg az óvodai nevelésben és nem csak a matematikai foglalkozások során zajlik. A halmazok részterületéhez hasonlóan itt is minden fejlesztés először szókincsbővítéssel, fogalmak megismertetésével kezdődik, amelyeket következetesen szükséges alkalmazni. Emellett a geometriához kapcsolódó készségek fejlődése legtöbbször olyan játékos tevékenységek által megy végbe, amelyek során valamit alkotnak a gyermekek (Perlai, 1997). Így az építőjátékoktól kezdve, a gyurmázáson át, a papírvágásig számos olyan foglalkozás sorolható fel, ahol az észlelés és érzékelés (látás, tapintás), térszemlélet is fejlődik. Egyes fogalmak megtanítását segítheti tükör, papírvágás, mozgások leutánzása, amelyhez jól köthető a síkbeli és térbeli tájékozódás szavainak elsajátítása, ezáltal a relációkincs elemi alapkészségének fejlesztése is (Nagy et al., 2004a).

\section{Az óvodai matematikai nevelés elvei és módszerei}

Perlai (1997) szerint a matematikai nevelés sajátos elvei közé tartozik (1) a gyermekek életkori és egyéni sajátosságainak figyelembevétele, (2) az életszerüség, érthetőség, fokozatosság, (3) a motiváció, és (4) a játékosság. Véleménye szerint az óvodai matematikai nevelés eredményességét nagy mértékben befolyásolja az, hogy a felsorolt elvek mennyire jelennek meg az óvodai tevékenységek során. A hatékony pedagógiai munka során emellett elkerülhetetlen a gyermek egyéni jellemzői és fejlettségéhez való igazodás. Ennek érdekében is nyúlhatunk a pedagógiai értékelés változatos eszközeihez (Nagy et al. 2004a). Ezekben a gondolatokban a matematikai módszertani leírásoknál Dienes Zoltán alapelvei köszönnek 
vissza, amelyek szintén ezt a szemléletet erősítik (Dienes, 1999). Amelyek a hazai iskolai matematikatanításba Varga Tamás „komplex matematikatanítás kísérlete” által jutottak el, ő volt az, aki átvette és a hazai oktatási környezethez igazította azokat (C. Neményi, 2002).

A Perlai (1997) által felsorolt életszerüség, érthetőség, fokozatosság elve mentén tervezhetők meg matematikai tartalmú óvodai foglalkozások. Egy-egy matematikai foglalkozás alkalmával olyan egyszerü problémahelyzeteket mutatunk be a gyermekeknek, amelyek által építhetnek mindennapi tapasztalataikra, természetes kíváncsiságukra. A problémahelyzeteknél fontos, hogy azokat kellőképp megértsék, kapcsolni tudják hétköznapi helyzetekhez. Emellett e korcsoport esetében is különösen fontos, hogy építsünk a meglévő ismereteikre, tapasztalataikra, így mutatva meg számunkra új feladatokat, ismereteket, múveleteket. Kisgyermekeknél különösképpen igaz, hogy figyelmüket nagymértékben meghatározza az érdeklődésük. A gyermekeket körülvevő világ jelenségei, eseményei változatos ideig tudják lekötni a figyelmüket, ezért annak érdekében, hogy a gyermek odafigyelve, aktívan vegyen részt a foglalkozásokon, fel kell kelteni az érdeklődését, amelyet a szervezet foglalkozások elején „motiváció” vagy „ráhangolás” rész során szoktunk megtenni, mesével, dallal, mondókával. Ezt követően, annak érdekében, hogy érdeklődésük és figyelmük fenn is maradjon, a foglalkozások alatt játékos feladathelyzeteket kell teremtenünk, így a tanulás játékos keretek között mehet végbe. Ez segíti, hogy a matematikai tapasztalatszerzése élményszerüen történjen, és annak feladataihoz a gyermekek pozitívan viszonyuljanak a jövőben is (Perlai, 1997; Körmöci, 2014).

\section{Iskolakészültség fogalomrendszere és a számolási készségek szerepe}

Az eredményes iskolakezdés feltétele, hogy a tanuló felkészülten kezdje meg általános iskolai tanulmányait. Ezért a gyermekek iskolakészültsége, az iskolakezdés időszakának kognitív, szociális és érzelmi fejlettsége régóta a pszichológiai és neveléstudomány kutatások fókuszában áll, nemzetközi és hazai szakirodalomban is olvashatunk az iskolakészültség fogalmáról (Duncan et al., 2007), a gyermekek optimális fejlettségi szintjéről (Nagy et. al, 2004a). A gyermekek fejlettségének felmérésére különböző eszközök, eljárások kerültek kidolgozásra, egy részükről részletes empirikus eredmények is rendelkezésünkre állnak (Nagy et al., 2004b; Snow \& Van Hemel, 2008).

Az iskolakészültség meglehetősen összetett fogalmának leírására vonatkozóan a nemzetközi szakirodalomban számos tartalmi keretrendszerrel találkozhatunk, a különböző megközelítések más-más összetevőt helyeznek előtérbe (Scott-Little, Kagan, \& Frelow, 2006), 
a szakirodalom jelentős részében általánosan elfogadott, hogy az iskolakészültség fogalmába egyaránt beletartozik a gyermek fizikai állapota, szociális és kognitív fejlettsége, és sokszor még ennél is több összetevőt határoznak meg, amelyek egymással összefüggve befolyásolják a későbbi iskolai teljesítményt (Hair et al., 2006).

A hazai szakirodalomban Nagy József $(1980,1987)$ a PREFER teszt kidolgozásakor foglalta össze azoknak az alapkészségeknek a rendszerét, amelyek a sikeres iskolakezdéshez szükségesek. Az általa felvázolt rendszerben az iskolaérettség fogalmát szükebb értelemben használta, amely a gyermek iskolakészültségének, kognitív, szociális és személyes összetevőket magába foglaló rendszerén belül helyezhető el. Bár, a nemzetközi szakirodalomban egységesen alkalmazott „,school readiness” fogalmát, a magyarra rendszerint iskolaérettségnek fordítják, és a magyar nyelvü szakirodalom széles körét e fogalom mentén találjuk meg, mi is az iskolakészültség kifejezés használata mellett foglalunk állást. Így a dolgozat egészében következetesen ezt a kifejezést használjuk, amelyen belül több összetevő (fizikai állapot, kognitív, szociális készségek) együttes fejlődését és az iskolakezdésben meghatározó szerepét hangsúlyozzuk, és ennek megfelelően tárgyaljuk az iskolakészültség alkotóelemeit is. Fogalomhasználatunk alapját képezi emellett az a nemzetközi szakirodalomban egységes álláspont, miszerint az iskolakezdés továbbra is elsődleges meghatározója, a gyermek életkora korántsem garancia a gyermek felkészültségére (Gredler, 1992, idézi: Hair, Halle, Terry-Humen, Lavelle, \& Calkins, 2006). Miközben az iskolaérettség kifejezés, az iskolakészültséggel szemben, az életkor kiemeltebb szerepét sugallja.

Az iskolakészültségben szereplő fejlettségbeli összetevők illusztrálásához a Kagan, Moore és Bradekamp (1995) által kidolgozott részletes keretrendszert ismertetjük, amelyben 5 fő dimenziót határoztak meg a gyermekek iskolára való felkészültségének leírására. Az első az általános fizikai állapot, aminek része a gyermek mérete, testtömege mellett a motoros készségeinek fejlettsége és egészségi állapota is. A következő dimenzióba a szociális és érzelmi fejlettséget sorolták, ennek fontos elemként megjelölve a kortársakkal és a tanárokkal való pozitív kapcsolatot. A harmadik dimenzióban a gyermekek a tanuláshoz való viszonya szerepel, amely a feladatvállalást, feladattartást is magába foglalja. A negyedik dimenzióba elkülönítve jelenítik meg a gyermekek nyelvi fejlettségét, melyek részei a beszédértés, az alapszókincs és azok az alapkészségek, amelyek később az írás-olvasás fejlődéséhez lesznek szükségesek. Az utolsó dimenzióban kapnak helyet a gyermek kognitív fejlettségéhez kapcsolódó összetevők, beleértve az észlelés-érzékelés alapmotívumait, tárgyak közötti kapcsolatok megértését is. Ezek a fejlődési területek később számos iskolakészültséget célzó vizsgálatnál is megjelentek (Snow \& Van Hemel, 2008). 
A számolási készségek iskolakezdéskori fejlettségének jelentősége többször felmerült már a dolgozatban. Meghatározó szerepét kiemeltünk a bevezetésben és a korai numerikus készségek fejlődését bemutató fejezetben is. A korábban ismertetett gondolatokat az iskolakészültség fogalomrendszerében elfoglalt helyével egészítjük most ki, mivel az utóbbi tíz évben egyre több kutatás foglalkozik az iskolakészültség kognitív összetevőin belül kifejezetten a matematika tanulásához kacsolható készségek fejlettségével (Jordan et al., 2009; Aunio \& Niemivirta, 2010). Ennek egyértelmü oka, hogy a matematika a világ minden részén egyformán meghatározó iskolai tantárgy, fejlödésével több nemzetközi rendszerszintű mérés is foglalkozik (IEA TIMSS, OECD PISA), amelyek rávilágítanak a tanulók matematika teljesítményével, az iskolában tanultak alkalmazásával kapcsolatos problémákra (Csíkos \& Vidákovich, 2012). Longitudinális vizsgálatok pedig már az iskola kezdő szakaszában jelzik a későbbi gyengébb teljesítmények kiváltó lehetséges okokat. Természetesen a tanulók teljesítményére számos tényező, például családi háttér, szelektív iskolarendszer (Csapó, Fejes, Kinyó, \& Tóth, 2014), hatást gyakorol, az mégis észlelhető, hogy a tanulók közötti különbségek jelentős része már az iskolába lépéskor fennáll, és sok iskolarendszer ezeket a különbségeket nem tudja csökkenteni, sőt azokban az országokban, ahol szelektívebb az iskolarendszer, még inkább fel is erősíti. Ennek következtében válik különösen jelentőssé az óvoda és iskolakezdés időszaka, ahol a lemaradásokat időben észlelve, még sokkal kevesebb erőfeszítéssel lehet felzárkóztani a tanulókat. Erre az elgondolásra indultak el például az Egyesült Államokban a hátrányos helyzetü gyermekek iskolai sikerességének biztosítását célzó „Head Start” programok (Arnold, Fisher, Doctoroff, \& Dobbs, 2002).

Az iskolakészültség vizsgálata évtizedek óta kiemelkedő kutatási területnek tekinthető (Barbu, Yaden, Levine-Donnerstein, \& Marx, 2015) a kidolgozott vizsgálati eljárások a célcsoport életkori sajátosságait alapul véve elsősorban szemtől szembeni kikérdezésen és megfigyelésen alapulnak, így azok eredményeit a kikérdező, illetve megfigyelő által szubjektív tényezők is befolyásolhatják (Csapó, Molnár, \& Nagy, 2015). A hazai iskolaérettségi vizsgálatok gyakorlatát Apró (2013) mutatja be részletesen, aki vizsgálatában az óvodák által alkalmazott mérőeszközöket és eljárásokat térképezte fel. A felmérésben résztvevő óvodák többsége napjainkban még nem használ standardizált mérőeszközt a gyermekek fejlödésének monitorozására, jelentős részük az óvodapedagógus megfigyelésére alapozva dokumentálja a gyermekek fejlődését. Azokban az intézmények, ahol mérőeszközöket alkalmaznak, a DIFER tesztbattéria a legelterjedtebb. Mivel a jelenleg hatályos jogszabályok szerint a gyermekek iskolakezdéséről az óvoda vezetője dönt, így fontos, hogy milyen szempontok alapján hozzák meg ezt a döntést. Emellett a szülők vagy az óvodavezető kezdeményezésére a területileg 
illetékes pedagógiai szakszolgálat, pedagógusokból, gyógypedagógusokból, pszichológusokból álló szakértő bizottsága méri fel a gyermek iskolakészültségét (Köznevelési Törvény, 2011). A szakértő bizottságok vizsgálati eljárásáról, annak tudományos hátteréről, vagy az ott alkalmazott mérőeszközökről azonban nem található számottevő információ, a vizsgálatok akárcsak az óvodai vizsgálatoknál, megfigyelésen és személyes kikérdezésen alapulnak. A vizsgálatok részei között szerepel a gyermekek viselkedésének megfigyelése, nyelvi, kognitív, pszichomotoros fejlettségük felmérése, amelyek mellett helyett kapott a számolás vizsgálata is, ugyanakkor ennek elsődleges feladata a számolási zavarok diagnosztizálása (Torda, 2016).

\subsection{Az iskolai matematikatanulás első évei}

Amint az korábban felvázoltuk, iskolába lépéskor a gyermekek között jelentős fejlettségbeli különbségek vannak. Ez igaz a számolás, matematika tekintetében is, ez az időszak több szempontból is meghatározó és kihat a gyermekek későbbi iskolai matematika teljesítményére. Annak érdekében, hogy a korai numerikus készségek jelentőségét összefüggéseiben szemléltessük, fontos bemutatnunk az iskolai matematikatanulás kezdeti szakaszának tartalmi területeit, valamint ismertetni, miként játszanak szerepet a numerikus készségek az iskolában megjelenő matematikai fogalmak és fö tartalmi területek tananyagának megértésében. Ebben az alfejezetben az alsó tagozatos matematika tantervi kereteit, a matematika fö területeinek az iskola első két évfolyamán megjelenő részeit tárgyaljuk, amelyeknél az óvodai matematikai nevelés során elsajátított, matematikatanuláshoz szükséges szerepére is kitérünk. Végül röviden írunk az elsajátított matematikatudás alkalmazásának kérdéseiről is.

\section{Az iskolai matematikatanulás tartalma és tantervi keretei}

Iskolába lépve a gyermekek az óvodához képest sokkal szervezettebb keretek között kezdenek tanulni, bár az iskolára való felkészítés során már az óvodai csoportban is elkezdtek hozzászokni a szervezett kiscsoportos foglalkozásokhoz. Ezek a tevékenységek azonban sokkal játékosabb formában zajlanak, és jellemzően azokat megelőzően és követően is szabad játék volt a napirend (Perlai, 1997). Az alsó tagozatban ennél már kötöttebb órarendben tanulnak, ugyanakkor a matematikai fejlesztés itt is még kezdetekben a gyermekek tapasztalataira, cselekedtetésre és szemléltetésre építve halad az absztraktabb fogalmak megértése felé. Elkezdődik a gyermekek által megtapasztaltak és a különféle szimbólumok és fogalmak 
kapcsolatának megteremtése (Csíkos, Molnár, \& Csapó, 2015). A hatályos kerettantervben (EMMI, 2012) leírtak szerint, az első évfolyamokon a matematikatanulás-tanítás célja a gyermekek személyiségének és gondolkodásának formálása, és a matematika tudományának megismertetése játékos tevékenységek és a fokozatosság elve szerint, elsősorban tapasztalatokon alapuló megismerési módszerek használatával. Egyes kutatások szerint ebben a viszonylag rövid kezdeti szakaszban is fel lehet halmozni olyan lemaradást, amelyet behozni később már csak fáradságos munkával lehet. Az iskoláztatás kezdetén a fogalmak megértését gátolhatja, a számolási készségek alacsony fejlettsége mellett, a beszédértés problémája, valamint a szókincs, különösen a relációszókincs területén jelenlévő hiányosságok (Jordan et al., 2009; Jordan, Glutting, \& Ramineni, 2010; Nagy et al., 2004a).

A matematika alsó tagozatban megjelenő tartalmi összetevőit, azok egymásra épülését Szendrei és Szendrei (2011), valamint Csíkos és Csapó (2015) munkái alapján mutatjuk be. A matematika elsődleges tartalmi területeit és a hozzájuk tartozó területeket a 2. táblázatban soroljuk fel, amelyből kiderül, hogy az iskolai matematikatanulás első éveiben is már az öt fö terület, és az ezekhez kapcsolódó alegységek, fogalmak megtanítása jelenik meg. A következő bekezdésekben ezeket a területeket ismertetjük az általános iskola alsó tagozatára, amiken belül elsősorban az első és második évfolyamon megjelentő fogalmakat emeljük ki.

2. táblázat. A matematika fö területei (Szendrei \& Szendrei, 2011, p.104)

\begin{tabular}{ll}
\hline Elsődleges tartalmi területek & A Mathematics Subject Classification szerinti fö területek \\
\hline Számok, müveletek, algebra & $\begin{array}{l}\text { 11: Számelmélet (Number theory) } \\
\text { 12: Testelmélet és polinomok (Field theory and poly- } \\
\text { nomials) } \\
\text { [az absztrakt algebra további területei (further topics of } \\
\text { abstract algebra): 06, 08, 13-22] }\end{array}$ \\
\hline Relációk, függvények & 26: Valós függvények (Real functions) \\
& [az analízis és differenciálegyenletek további területei \\
& (further topics of analysis and differential equations): \\
& 28-49] \\
\hline Geometria & 51: Geometria (Geometry) \\
& [a geometria és topológia további területei (further \\
& topics of geometry and topology): 52-58] \\
\hline Kombinatorika, valószínüség- & 05: Kombinatorika (Combinatorics) \\
számítás, statisztika & 60: Valószínüségelmélet és sztochasztikus folyamatok \\
& (Probability theory and stochastic processes) \\
& 62: Statisztika (Statistics) \\
\hline A matematikai gondolkodás & 03: Matematikai logika és a matematika alapjai \\
módszerei & (Mathematical logic and foundations) \\
\hline
\end{tabular}


Az első fő terület a számok, müveletek és algebra témakör, ez adja a matematika alapjait, ezért nem véletlen, hogy az iskola első éveiben ez a terület jelenik meg leghangsúlyosabban. A Nemzeti alaptantervre (2012) épülő kerettantervek (EMMI, 2012) alapján, első és második osztályban az erre szánt órakeret összesen 147 órát tesz ki. Összehasonlításképpen, a többi tartalmi területre ezekben az években összesen 88 tanóra jut, a relációkra, függvényekre 32 óra, geometriára 46 óra, statisztika és valószínüség témakörére pedig mindössze 10 óra. A matematikai gondolkodási módszerek fejlesztése a többi terület tanítása közben folyamatosan történik, erre külön órakeretet nem határoztak meg. A számok, müveletek, algebra témaköreihez tartozik a számfogalom, a számkörök, és a négy alapművelet és jeleik elsajátítása, amellyel az algebra témakörének első elemei is megjelennek (Csíkos \& Csapó, 2011). Az óvodában megtapasztalt egész számok rendszerét itt tovább bővítjük, az arab számok felismerése és hangos leolvasása, a számolvasás is ebben az időszakban fejlődik nagy mértékben (Józsa, 2015). E területhez kapcsolódóik szorosan a korábban már ismertetett mentális számegyenes fogalma (Opfer \& Siegler, 2013), és Dehaene (2003) hármas kódolás elmélete. A mentális számegyenes ebben az időszakban alakul át lineárissá, amelynek köszönhetően az átlagosan fejlődő gyermekek 8 éves korukra a számok helyét, és a közöttük lévő távolságot is meg tudják határozni 100-as számkörben. Emellett a számok írott jelét, verbális nevét, és az általuk reprezentált mennyiségeket is megfelelően már össze tudják kapcsolni (Csíkos \& Csapó, 2011; Opfer \& Siegler, 2013; Dehaene, 2003).

Egy másik terület, amelynek tanítása már szintén alsó tagozatban is szerepet kap a relációk és függvények témaköre. A témakör tanítása a halmazok és halmazok közötti hozzárendelések matematikai alapfogalmain nyugszik (Szendrei \& Szendrei, 2011). A kerettanterv ennek 1-2. évfolyamos tanításához mindössze a tárgyak sorba rendezését és az idővel kapcsolatos tapasztalatokat nevezi meg előzetes tudásként (EMMI, 2012), miközben a témakör fogalmainak megértéshez még kötődik a DIFER tesztben is vizsgált összefüggések megértése is (Nagy et al., 2004a). Továbbá több tipikus induktív gondolkodási művelet (Csapó, 1998) fejlesztése is megtörténik a témakörhöz kapcsoltan, például jellemzőek a számsorozat szabályának felismerésére és folytatására vonatkozó iskolai feladatok ezeken az évfolyamokon, amelyhez gyermekeknek elengedhetetlen ismerniük a korai numerikus készségek közül a számok nevét és sorrendjét elengedhetetlen ismerniük.

A geometria területére jut még több idő az első és második évfolyamon, ennek fontos óvodai előzménye a térszemlélet és a tájékozódás, amelyekről az óvodai matematikai nevelés tartalmánál írtunk. Alsó tagozaton ezekre építve folytatódik a gyermekek tér- és síkgeometriai szemléletének fejlesztése, amelynél változatos szemléltetőeszközök, tevékenységek 
alkalmazhatók. A korai numerikus készségek összetevői közül, a geometriai alakzatok felismeréséhez és leírásához szükséges a számok ismerete, és a mennyiségekkel szerzett tapasztalataik lehetnek még meghatározó előfeltételek. A számolási készségek említett elemei mellett, az elemi alapkészségek közül a relációszókincsben is fellelhető téri tájékozódási szavak, valamint mennyiségi relációszavak ismerete és pontos használata is alapvető (Nagy et al., 2004a).

A felsorolt matematikai területek közül a statisztika és valószínűség témakörére marad a legkevesebb időkeret az iskola első két évében. Alsó tagozaton inkább a tapasztalatszerzésen és alapkészségek fejlesztésén van a hangsúly, ezek között a kombinatív és a valószínüségi gondolkodás fejlesztése kezdődik meg, különböző rendszerezési feladatokkal, események megfigyelésével (Csíkos \& Csapó, 2011).

Az utolsó tartalmi terület a matematikai gondolkodás módszerei, amely külön órakeret nélkül, folyamatosan jelen van az alsó tagozatos matematikai tevékenységekben. Ennek magyarázata lehet, hogy a matematikai gondolkodás szorosan összefügg az elöbb bemutatott területek mindegyikével, és fejlődése már kisgyermekkorban a számolás fejlődésével együtt elkezdődik. A felsorolt területek a gondolkodás fejlesztésének színtereként is funkcionálnak (Szendrei \& Szendrei, 2011). Ez a kerettanterv fejlesztési céljai között nyomon is követhető, amiben a többi témakör elemei egyböl visszaköszönnek. Célként jelölték meg a matematikai szakkifejezések megismerését, tárgyak, személyek összehasonlítását, a halmazelmélet megalapozását, és a gyermekek gondolatainak, megfigyeléseinek kifejezését is (EMMI, 2012).

\section{A matematikai tudás alkalmazása}

Az óvodai matematikai neveléssel megalapozva, majd ezt követően az iskolai első éveiben kezdődik meg a tanulók matematikatanulása a bemutatott témakörökkel, ezek tartalmi elemei, fogalmai egymásra épülnek, összefüggenek egymással, így képezik alapját mindannak, amit a diákok a következő 10 évben fognak tanulni, és amelyek visszaköszönnek az Országos Kompetenciamérés, a TIMSS, vagy a PISA felmérésein is, és amelyek jelentő részét használniuk is kell majd felnőtt korukban, legyen szó hétköznapi helyzetekről, vagy a munka világáról, ezért is tárgyaljuk a következő alfejezetben a matematika alkalmazásának területét.

Csíkos és Verschaffel (2011) szerint a matematika fontos szerepet tölt be abban, hogy a tanulókban felmerüljön az igény a megszerzett matematikai tudásuk alkalmazására más iskolai tantárgyak keretei között, valamint iskolán kívüli problémák megoldásában. Az OECD PISA mérés egyik fő területe a matematika, amely 2003-ban és 2012-ben is kiemelt területként 
szerepelt a méréseken. A PISA mérésekben a matematikai müveltség területénél azt vizsgálják, hogy „mennyire képesek a tanulók a matematikai gondolkodásra, mennyire tudják magukat matematikailag kifejezni, hogyan tudják alkalmazni a matematikát, és különböző valós szituációkat képesek-e matematikailag értelmezni” (Ostorics, Szalay, Szepesi, \& Vadász, 2016, p. 43). A OECD definíciója értelmében a matematikai müveltség által az állampolgárok felismerik és megértik a matematika a világban betöltött szerepét, és segítségével megfontoltan, felelős, és megalapozott ítéleteket, döntéseket képesek hozni (OECD, 2016; Csíkos \& Verschaffel, 2011).

A magyar tanulók matematikai müveltségéről több mint egy évtizede szolgálnak információval az OECD tanulói tudásszintmérései. A PISA méréseken matematikából 2009-ig az OECD átlagnak megfelelően teljesítettek a magyar tanulók, azonban a 2012-es mérésre jelentősen leromlott a matematikaeredmény, amely a következö, 2015-ös mérésen is ezen a szinten maradt (10. ábra). Ennél talán sokkal súlyosabb probléma, és további aggodalomra adhat okot, hogy eközben a gyengén teljesítő tanulók aránya a 2003-2009 közötti 21-23\%-ról 2012-ben 28,1\%-ra nőtt és 2015-ben is 27,7\% volt. Gyengén teljesítök alatt azokat a tanulókat értjük, akik a mérésen nem érték el a 2. képességszintet, amely ahhoz szükséges, hogy valaki az iskolából kikerülve részt tudjon venni a társadalmi életben, alapvető számolási feladatokat el tudjon végezni, igazából az alapszint alatt lévő tanulók az alsó tagozatban tanult matematikai fogalmakat, eljárásokat sem képesek megfelelően alkalmazni (Csapó et al., 2014; Ostorics et al., 2016).

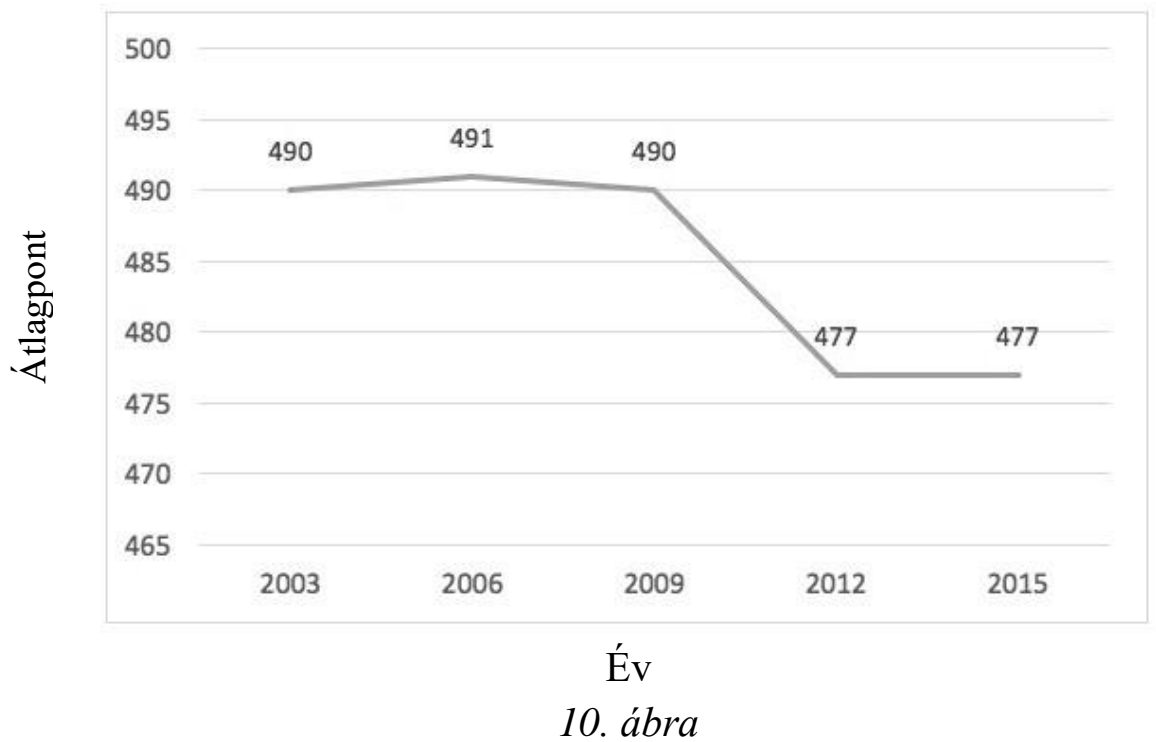

A magyar tanulók teljesitménye 2003 és 2015 között az OECD PISA matematika területén (Forrás: OECD, 2016) 
A PISA eredmények is rávilágítanak arra, hogy az iskola kezdő szakaszának matematikatanulását és a lemaradásban lévő gyermekeket minél előbb azonosítani kell, hogy időben részt vehessenek felzárkóztató programokban, képesek legyen elsajátítani az alsó tagozatban megszerezhető matematikai alapokat. Ha ez nem történik meg, fejlödésük óhatatlanul megreked, és nem lesznek képesek lépést tartani kortásaikkal. Középiskolában észlelve a problémákat sajnos már nagyobb energiabefektetéssel is csak keveset lehet tenni.

\section{3. Összefoglalás}

A dolgozatban bemutatott vizsgálataink kontextusához elengedhetetlennek tartottuk, hogy összefoglaljuk azt óvodai és iskolai matematikatanítás 4-8 éves gyermekeket érintő legalapvetőbb elemeit, melyek áttekintésekor törekedtünk rávilágítani az előző fejezetben részletesen tárgyalt korai numerikus készségek helyére és szerepére.

A fejezetben áttekintettük az óvoda és általános iskola alsó tagozatának matematikai tartalmi keretrendszerét, amelyen belül az óvoda-iskola átmenet időszakának intézményes fejlesztési keretekre fókuszáltunk. Az óvodai matematikai nevelés céljainak, tartalmának, módszereinek ismertetését követően bemutattuk az iskolakészültség fogalmát, annak legfontosabb alkotóelemeit, valamint a korai numerikus készségek ezek között elfoglalt helyét. A témához kapcsolódóan érintettük az iskolakészültség vizsgálatának magyarországi helyzetét is. Végül az általános iskola első két évfolyamának matematikatanítását részleteztük és röviden kitekintést nyújtottunk a matematika alkalmazására, elsősorban a hazai PISA matematika eredmények tendenciáira.

\section{DIGITÁLIS ESZKÖZÖK AZ OKTATÁSBAN - A TECHNOLÓGIA ALAPÚ MÉRÉS}

\subsection{Digitális eszközök az oktatásban}

A felgyorsult technológiai fejlődés napjainkra megváltoztatta az emberek életét, gyökeres változásokat hozott a hétköznapok és a munka világában is. Nem véletlenül nevezik ezt az időszakot digitális forradalomnak, vagy az utóbbi években az iparra gyakorolt hatása miatt, negyedik ipari forradalomnak (Peters, 2017). A fejlődés az iskola világát sem kerülte el, digitális technológia segítségével közelebb hozhatjuk a tananyagot a kevésbé motivált tanulókhoz, elősegítheti a magasabb fokú szemléltetést, illusztrációt és szimulációt 
(Buckingham, 2007). Emellett alkalmazkodhatunk a tanulók egyéni szükségleteihez, megkönnyítheti és játékossá teheti a tanulók értékelését, például a formatív értékelést online kvízzé alakítva, valamint támogatást biztosíthatunk a tanórán kívül is. A technológia számos olyan lehetőséget is magában hordoz, amit a lemaradásban lévő, hátrányosabb helyzetű tanulók felzárkóztatására is lehet használni (Grabe \& Grab, 2007; Schrum \& Levin, 2015; Molnár, 2011). A fejezetben a digitális technológiai fejlődésnek köszönhetően elterjedő technológia alapú mérés-értékelés lehetőségeit és kihívásait tekintjük át, amelynek végén külön részt szentelünk a kisgyermekek mérésével kapcsolatos új lehetőségek és korlátok bemutatásának.

A számítógépek, IKT-eszközök elterjedésével együtt megjelent és fokozatosan kiemelkedő jelentőségűvé vált a tanulók digitális kompetenciája, amely egy összetett, számos készségből, ismeretből és attitűdből álló rendszer (Tóth-Mózer \& Kárpáti, 2016). Emiatt is bír különösen nagy jelentőséggel a digitális oktatási eszközök és módszerek alkalmazása az oktatásban, hiszen a diákok digitális kompetenciájának fejlesztése a modern világban lassan egyenértékűvé válik a szövegértés vagy alapvető számolási készségek jelentőségével (Seufert \& Scheffler, 2016). Miközben megjelent és a közvélekedésben még tartja magát a digitális bennszülöttek mítosza, azt látjuk, hogy a tanulók digitális kompetenciájának fejlettsége elmarad az elvárásoktól. Több vizsgálat is felhívja a figyelmet arra, hogy az úgynevezett digitális generáció jelentős részének igenis gondjai vannak a digitális eszközök megfelelő felhasználásával, digitális kompetenciájuk összetevőinek fejlettsége koránt sem olyan magas, mint azt sokan még mindig feltételezik (Kirschner \& De Bruyckere, 2017). Ez különösen igaz a hátrányos helyzetű tanulókra, akik fokozottan vannak kitéve a lemaradás, lemorzsolódás veszélyének (Hargreaves, 2011).

Az utóbbi években megjelent digitális oktatási eszközök, legyen szó akár a diákokkal való kommunikációról, vagy a szemléltetést magasabb szintre emelő médiumokról, nagy mértékben segíthetik a pedagógusok munkáját, amennyiben azok közül körültekintően válogatnak, a kiválasztott eszközöket és módszereket megfelelően, pedagógiai céljaihoz rendelve alkalmazzák. A digitális technológia oktatásba történő integrálásával számos fontos célt el tudunk érni, megvalósíthatjuk a tanulók 21. századi képességeinek fejlesztését, támogathatjuk egyéni tanulási útjukat, valamint elősegíthetjük az egész életen át történő tanulást (Ng, 2015). Az új, digitális technológia nyújtotta lehetőségek közül egyre inkább kezd terjedni a technológiai-alapú mérés az oktatás különböző szintjein, amellyel a következő alfejezetekben részletesen foglalkozunk. 


\subsection{Technológia alapú mérés az oktatásban}

A technológia alapú mérés elterjedése és jelenlegi helyzete

Az előzőekben bemutatott technológiai fejlődés hatásai az osztályterem, az iskola és az egész oktatási rendszer egészének szintjén természetesen nem kerülték el a pedagógiai mérésértékelés területét sem, amellyel szemben jogos elvárásként fogalmazódik meg, hogy alkalmazkodjon a 21. század elvárásaihoz, és használja ki technológiai fejlődésben rejlő lehetőségeket (Molnár, 2010).

Jelen áttekintésünkben a technológia alapú mérés terminust szükebb értelemben használjuk, az alatt azokat a digitális eszközökkel végzett pedagógiai és pszichológiai méréseket, vizsgálatokat értjük, amelyek során az adatfelvétel során információk, kérdések megjelenítése, válaszok begyüjtése, az adatok rögzítése, feldolgozása és kiértékelése egyaránt technológián keresztül valósul meg. Ilyen értelemben a fogalomba beletartozik akár a hagyományosnak tekinthető, asztali számítógépen keresztüli tesztfelvétel, egy interaktív táblán kitöltött tanórai kvíz, vagy a mobiltelefonon keresztül megválaszolt kérdőív, ugyanakkor nem vonatkozik a matematika dolgozatnál használt számológépre, vagy a számítógépen megírt, majd kinyomtatott esszére (Csapó, Molnár, \& R. Tóth, 2008; Molnár, 2010).

A technológia alapú tesztelésen belül további mérés-értékelési rendszerek helyezkednek el, amelyeket az eszközök típusának és tesztelés kivitelezésének tekintetében csoportosíthatunk (11. ábra). A legtágabb halmazt maga a technológia alapú mérés-értékelés képezi, ezen belül helyezkedik el az oktatási gyakorlat legelterjedtebb rendszere számítógép-alapú mérésértékelés. Ebben a számítógép képernyőjén megjelenő teszteket a számítógépen keresztül töltik ki, majd dolgozzák fel. A következő halmazba a hálózat-alapú mérés-értékelés eszközei kerülnek, amely esetében a tesztelés hálózaton keresztül, több számítógép összekapcsolásával zajlik, ezen belül kapott helyet az internet-alapú, vagy online mérés-értékelés, amikor a teszt minden információja az interneten keresztül áramlik, és a teszt adatainak rögzítése általában egy távol eső szerveren történik. Az okostelefonok és tabletek, valamint a mobilinternet elterjedésével a halmazok közötti határok azonban kezdenek elmosódni, és a jövőben leginkább az online mérés-értékelés térnyerése várható. 


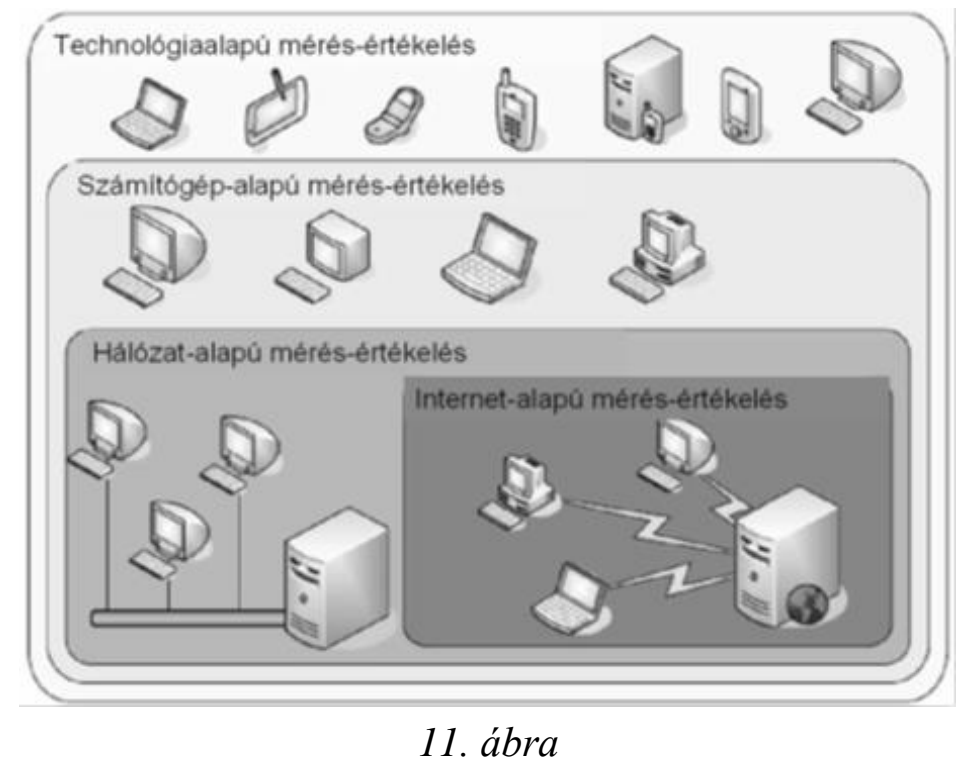

A technológia alapú, a számitógép alapú, a hálózat és internetalapú mérés-értékelés hierarchikus viszonya

(Csapó, Molnár, \& R. Tóth, 2008, p. 9; Jurecka \& Hartig, 2007 alapján)

A technológia alapú mérés-értékelés alkalmazását a pedagógiai gyakorlatban nem pusztán a technológiai fejlődés indokolja, az abban rejlő lehetőségek kiaknázása az értékelés alapvető funkcióiból fakad, melynek lényege visszacsatolás nyújtása a tanulás céljaira, a tanuló teljesítményére, a tanítás-tanulási folyamatra (Báthory, 2000). A technológia segítségével pedig ezt a visszacsatolási, visszajelentési folyamatot lényegesen gyorsabbá, hatékonyabbá és nem utolsó sorban gazdaságosabbá is tehetjük, mely szempontok mind elvárásként jelennek meg a modern oktatási rendszerek működésénél (Csapó, Lőrincz, \& Molnár, 2012).

A tanítási-tanulási folyamat viszonylatában meghatározható pedagógiai értékelési formák, a diagnosztikus, formatív és szummatív értékelés esetében a technológia alapú értékelés felhasználási lehetőségei szerteágazóak. Diagnosztikus értékelésnél betöltött szerepét a Szegedi Tudományegyetem Oktatáselméleti Kutatócsoportjában végzett Diagnosztikus mérések fejlesztése kutatási projekttel kiválóan lehet szemléltetni. A projekt keretében 1-6. évfolyamos tanulók tudásának felmérésére hoztak létre egy elektronikus diagnosztikus mérésiértékelési rendszert (eDia) az olvasás-szövegértés, matematika, természettudományi fő területein és további részterületeken (Molnár \& Csapó, 2013). A rendszer fejlesztésének legújabb kutatási iránya egy iskolakezdő mérőcsomag fejlesztése, amelynek jelen kutatásunk is szerves részét képezi. A kutatások legfőbb célja a tanulók egyéni fejlődésének nyomon követése, visszajelzése, és a lemaradásban lévő tanulók azonosítása (Csapó, Hódi, Kiss, Pásztor, Rausch, \& Molnár, 2017). A technológia a tanórai munka meghatározó részét képező 
formatív értékelésnél legalább ilyen kiterjedt lehetőségeket nyújt. A pedagógus számára azonnali ellenőrzést tudnak biztosítani a tanítási-tanulási folyamat bármely pontján, a digitális eszközökkel támogatott oktatás világában, a tanulók mobiltelefonjait akár szavazórendszerként használva, vagy csak egy egyszerű feleletválasztós kérdést projektoron kivetítve, az elérhető applikációk automatikus kiértékelésének köszönhetően gyorsan ellenőrizhető egy-egy fogalom megértése. Emellett az elektronikus formatív értékelés a 21. századi készségek fejlesztésénél is jelentős szerepet tölthet be (Spector, Ifenthaler, Sampson, Yang, Mukama, Warusavitarana, \& Bridges, 2016). Végül, a szummatív értékeléshez kapcsolódóan is számos új alternatívát biztosít a technológia. Az elektronikus formában lebonyolított összegző értékelésnél az előző két értékelési formánál bemutatott szempontok egyaránt érvényesülhetnek. A pedagógusok számára az előre rögzített javítókulcs, változatos feladattípusok lehetnek vonzóak, rendszerszinten pedig komoly kezdeményezések vannak különböző mérések, például az érettségi digitalizációjára, ahogyan az már több európai országban már sikeresen lezajlott (Kákonyi, 2014).

Amennyiben a technológia alapú értékelés pedagógiai gyakorlatát az oktatás szintjein végig nézve szemléljük, akkor az előző gondolatmenetet folytatva, a rendszerszintü mérésekben napjainkra betöltött kiemelkedő szerepével találkozunk. Sokéves fejlesztési és tesztelési folyamat eredményeképpen az OECD PISA mérések egy-egy részét már 2009-ben és 2012-ben is elektronikusan vették fel, végül 2015-ben már teljesen elektronikusan zajlottak a tanulói mérések (Ostorics, Szalay, Szepesi, \& Vadász, 2016). Hazai viszonylatban az országos és intézményi szintü visszacsatolást nyújt az Országos Kompetenciamérés, amelynek technológia alapú platformra történő átültetésre már szintén vannak kezdeményezések (Molnár, Magyar, Pásztor-Kovács, \& Hülber, 2015). Az osztálytermi és tanulói szint esetében ismételten az eDia online mérés-értékelési rendszerrel az SZTE Oktatáselméleti Kutatócsoport partneriskoláiban végzett vizsgálatokat hozhatjuk fel példaként, ahol a méréseket követően csoport- egyéni szinten biztosított a visszajelentés (Molnár, 2015).

\section{A pedagógiai mérés-értélés új lehetőségei}

A technológia alapú mérés-értékelés számos újdonságot hozott, amelyek nagymértékben kitágították a pedagógiai értékelés korábban ismert lehetőségeit. Számítógépes környezetben lehetőség a multimédiás elemeket beépítve alakíthatjuk ki a tesztelés menetét. A feladatok illusztrálásához papír alapon csak képek, ábrák és táblázatok beépítésére volt lehetőség. Napjainkban a tesztelés folyamatába könnyedén lehet videót, animációt beépíteni, amely 
segítheti a feladat megértését, valamint arra is van lehetőség, hogy a tanulók által adott válaszok határozzák meg az animáció tartalmát. Bizonyos jelenségeket számítógépes interakción keresztül szimulálhatunk, ezáltal korábban papír-ceruza tesztekkel nem mérhető gondolkodási müveleteket, képességeket is mérhetünk. Erre lehet példa a 2015-ös PISA mérés természettudomány alkalmazásának területe, amelynél egy nagymintás rendszerszintü mérésnél tudtak vizsgálni különböző kutatási készségeket, a mérésben résztvevő tanulók a teszten belül tervezhettek meg kísérleteket, amelyeket utána végre is tudtak hajtani, és a szimuláció eredményeképpen kapott adatokat kellett értelmezniük (Ostorics et al., 2016).

A számítógépes hálózatok és az internet lehetőségeit kihasználva napjainkban már nem csak a gép és a tanuló interakcióját vizsgálhatjuk, képesek vagyunk tanulók együttmüködését is mérni, akár úgy is, hogy fizikailag nem tartózkodnak egy térben. Az ebben rejlő potenciált kihasználva vizsgálja Pásztor-Kovács (2016) a tanulók kollaboratív problémamegoldó képességét, amely terület megjelent a 2015-ös PISA mérésben is (OECD, 2016). A szemléltetésen és interaktivitáson túl a hangok felhasználása adott alkalmat olvasásszövegértési képességek fejlettségétől független mérések kidolgozására, fiatalabb életkorban így a gyermekek olvasási képességei nem befolyásolják a tesztek eredményét (Molnár \& Pásztor, 2015a), ugyanakkor attól nem tekinthetünk el, hogy a kisgyermekek beszédértése ettől még hatással lehet a feladatok megoldására (Rausch \& Pásztor, 2017). Ezt részletesen a következő alfejezetünkben tárgyaljuk. Nem feltétlenül kisgyermekek méréséhez kapcsolódik, mégis az ő mérésüket könnyíti meg a manipuláció lehetősége, amely egy további nagy előnye a technológia alapú tesztelésnek. A számítógépes egér, vagy az érintőképernyő által lehetőség van a képernyőn megjelenő képek mozgatására, és az ezáltal történő válaszadásra. Ezzel nem csak kiválthatóak a papír-cezura tesztekben gyakran alkalmazott összekapcsolási feladatok, de készíthetők kizárólag figurális elemekből álló, manipulációval megoldható feladatok is (Csapó, Pásztor, \& Molnár, 2015; Magyar, Pásztor, Pásztor-Kovács, Pluhár, \& Molnár, 2015).

Számítógépekkel végzett tesztfelvétel esetében az sem elhanyagolható pozitívum, hogy nem csak a tanulók válaszait vagyunk képesek rögzíteni. A tesztelés során hatalmas számban gyüjthetök metaadatok is, elsőként a teszt és az egyes feladatokra fordított idő mérése könnyedén megoldható, de emellett monitorozhatjuk a kattintásokat, billentyük leütését, akár a kurzor mozgását is, valamint kielemezhetők a helytelen feladatmegoldások, megvizsgálhatók a végleges válasz előtt zajló események, javítások (Csapó, Lőrincz, \& Molnár, 2012). A tanulókról szerezhető információk köre jelenleg is folyamatosan bővül, kutatások foglalkoznak webkamerákat felhasználva arckifejezések rögzítésével és kielemzésével, (Lőrincz, Molnár, Jeni, Tőzsér, Rausch, Cohn, \& Csapó, 2013), a tanulók gondolkodási stratégiáinak 
megismerésére vonatkozóan vizsgálatok zajlanak a feladatmegoldás közbeni hangosan gondolkodtatásának módszerének alkalmazásával, a rögzített hanganyag és a teszt metaadatait összekapcsolva (Griffin \& Care, 2014), valamint az elmúlt évtizedben a szemmozgásvizsgálatot használó kutatások száma is növekedésnek indult (Steklács, 2014).

A korábban felsorolt feladattípusok, feladatmegoldási módok, kommunikációs és illusztrációs lehetőségekkel párhuzamosan jelenik meg a technológia alapú értékelés mellett, és papír-ceruza tesztekkel szemben, leggyakrabban felmerülő érv, az azonnali kiértékelés és visszacsatolás lehetősége. Legyen szó akár rendszerszintü mérésröl, akár a pedagógusok osztálytermi dolgozat íratásáról, a megspórolt idő, valamint a papír-alapú teszteknél adatrögzítésnél is elkövethető hiba eshetősége, egyaránt a technológia alapú mérések előnyét mutatják. A tesztek pontozását előre be lehet álltani, a tanulók válaszainak kiértékelése automatikusan zajlik, és a tanulói válaszoknak megfelelően elágazásokat is beépíthetünk a tesztekbe (Csapó, Lőrincz, \& Molnár, 2012). Így jutunk el az adaptív teszteléshez, amelynek gyökerei a 20. század eleji szóbeli kikérdezésen alapuló pszichológiai méréseinél már megjelentek, viszont a számítógépek és az internet elterjedésének köszönhetően egyészen új út nyílt meg a mérés ezen típusai előtt. Adaptív tesztek jellemzően egy közepes nehézségü feladattal kezdődnek, és a feladatok kitöltésekor a megoldás kiértékelését követően a számítógép dönt a következő feladatról, amely a kitöltő képességszintjéhez igazodik, így elérve, hogy a teszt kitöltése optimális kihívást nyújtson, ne legyen túl könnyü és unalmas, és ne legyen túl nehéz és frusztráló. Ez ahhoz is hozzájárul, hogy kevesebb feladattal, kevesebb idő alatt mégis pontosabb becslést kapjunk a tanulók képességszintjéről (Csapó, Molnár, \& R. Tóth, 2008; Magyar, 2012, 2014).

Az automatikus kiértékelést kihasználva, a webes alkalmazások elterjedésével megjelentek a pedagógusok értékelő munkáját, egyúttal a tanulók egyéni tanulási útját is támogató, ingyenesen hozzáférhető online tesztelési alkalmazások is. A számtalan platform közül csak párat említve, a Google Kérdőív, Socrative, Redmenta, Quizlet weboldalakon, illetve a hozzájuk kapcsolódó mobil alkalmazásokon keresztül gyorsan lehet különböző célú felméréseket végezni. A pedagógus jellemzően egyszerübb feladattípusok, feleletválasztás, igaz-hamis, valamint rövid szöveges válasz közül válogathat, amelynél a helyes válaszokat előre megadva, lepontozva a tesztek kitöltéséről azonnali eredményeket kap. A platformok többségéből Excel táblában is exportálhatók az eredmények. Az alkalmazások jelentős része (pl. Kahoot, Socrative) a formatív értékelést is segíti, a tanulói válaszok eloszlását és a helyes választ kivetítve, majd közösen megbeszélve növelhető a tanítási-tanulási folyamat 
hatékonysága, emellett a korábban már említett játékos kvízek, versenyek szervezése is egyszerüen megoldható (Hwang \& Chang, 2011).

Mindezeken felül a számítógépes mérések terjedése gazdasági szempontból is igen kedvező. Az automatikus kiértékelés kapcsán megemlített időbeli, adatrögzítési tényezők mellett a papír-alapú teszteléshez felhasznált papír és nyomdafesték megspórolása nem csak az intézményeknek költséghatékonyságát növeli, hanem környezetvédelmi szempontból is kiemelkedő jelentőséggel bír. Rendszerszintű mérések lebonyolításánál a papíralapú teszteknél sokszor a kinyomtatás jelenti a legkisebb problémát, a tesztcsomagok iskolákba történő eljuttatása, majd pedig onnan azok összegyüjtése nem kevés logisztikai kapacitást és koordinációt igényel. A mérésekhez a szükséges eszközpark kiépítését követően, amely, mint már említettük, az informatika tantárgy oktatása miatt egyébként is rendelkezésre áll, a technológiai alapon végzett mérések alkalomról-alkalomra hozzák vissza az infrastruktúrába fektetett összeget (Csapó, Lőrincz, \& Molnár, 2012).

\section{Korlátok a technológia-alapú mérések alkalmazásában}

Az eddig bemutatott technológia alapú mérés-értékeléssel kapcsolatos lehetőség és előnyök felsorolása után fontosnak tartjuk ismertetni azokat a felmerülő kihívásokat, amelyek mégis korlátként jelennek meg az infokommunikációs eszközök pedagógiai értékelési célú alkalmazásánál.

A gazdaságossági szempontok között merült fel, hogy a mérésekhez megfelelő eszközpark megléte szükséges. Napjaink gyors informatikai fejlődése miatt ezek az eszközök hamar elavulhatnak, amortizációjukat a megfelelő karbantartás hiánya is gyorsíthatja. Az eszközök oktatási célú alkalmazásánál, azon belül is föként az online méréseknél, akárcsak bármely számítógépes programnál, felmerül a minimális hardveres gépigény, vagyis azok a technikai specifikációk, amelyek megléte alapvetően szükséges adott program stabil futtatásához. Amennyiben az eszköz kapacitását meghaladja a méréshez szükséges program futtatása, előfordulhat, hogy másként jelennek meg a feladatok, akadozik a teszt kitöltése, amely jelentős hatással lehet a tanuló teszten elért teljesítményére is. Továbbá, ha a számítógép hardveres jellemzői, számítási és grafikus teljesítménye megfelelő is, még szoftveres oldalon is merülhetnek fel problémák, fontos az operációs rendszer, böngésző karbantartása, rendszeres frissítése, valamint a méréseket szervező pedagógusok számára technikai segítségnyújtás biztosítása (Bingimlas, 2009). 
Az előző problémakörhöz szorosan kapcsolódva merül fel, hogy a tesztet közvetítő médiumok milyen hatást gyakorolnak az eredményekre. A kérdés megválaszolására az elmúlt tíz évben több kutatási eredmény látott napvilágot. Kutatások jelentős része foglalkozott a papír alapú és az online tesztek összehasonlításával, amelyek elsősorban a kérdés komplexitására világítottak rá, hiszen a tesztkitöltést sok különböző tényező akár együttes hatása befolyásolhatja, ezek közé tartozik az előző bekezdésben ismertetett technikai háttér jellemzői, melynek része lehet a képernyő mérete és felbontása is, számíthat a tesztben megjelenített feladatok típusa és a válaszadás módja, amely szorosan kapcsolódik a vizsgált minta jellemzőihez, főként életkorához és családi hátteréhez (Csapó, Molnár, Pap-Szigeti, \& R. Tóth, 2009; Hülber \& Molnár, 2013).

Ezen kívül a tesztelés módját el kell fogadtatni az abban érintett szereplőkkel is, elsősoran a diákokkal és a pedagógusokkal. Erre irányuló vizggálatot Molnár és Magyar (2015) végzett, amelyböl érdekes módon az derült ki, hogy a pedagógusok jelentős része támogatja a számítógépes tesztelés terjedését, nagyobb arányban, mint a diákjaik. Emellett a szerzők azt is kiemelték, hogy azok körében magasabb a tesztelés e formájának elfogadottsága, akik már részt vettek technológia alapú felmérésben. Azonban annak érdekében, hogy ezt az elfogadottság tovább növekedjen nem elegendő az elektronikus mérésekben való részvétel bővítése. Ha például az adaptív tesztek alkalmazását nézzük, velük szemben kérdésként merülhet fel, hogy a pedagógus vagy épp szülö, miként tudja hagyományos megközelítésben értelmezni a teszten elért tanulói teljesítményt. Miközben a megszokott lineáris teszteknél a tanulók teljesítménye, tudása egyszerủen összevethető volt adott feladatok, tesztrészek mentén, adaptív teszteknél egészen másként kell az eredményeket értelmezni, ami kihívást jelenthet még a gyakorlottabb pedagógusok számára is, hiszen előfordulhat, hogy adott osztály tanulói teljesen eltérő feladatokat oldottak meg (Magyar, 2012).

\subsection{A technológia alapú mérés lehetőségei és kihívásai kisgyermekeknél}

A kisgyermekek mérésével kapcsolatos új lehetőségek egyes elemei már megfogalmazódtak az előző alfejezetekben is, ebben a részben egybegyüjtve mutatjuk be azokat a szempontokat, amelyek felmerülhetnek, amikor óvodás és kisiskolás gyermekek technológia alapú mérésértékelését tervezzük és valósítjuk meg.

A hordozható digitális eszközök elterjedése nyitott új a lehetőséget számítógép-alapú tesztelésben, amely így egyre fiatalabb életkori csoportoknál is kezdett megjelenni. Korábban a középiskolákban és a felsőoktatásban volt lehetőség IKT-eszközök széleskörü felhasználására 
mérés-értékelési célból. Sok országban, ahol a 4 vagy 6 évfolyamos elemi iskolákban nem kötelező tantárgy az informatika, nincsen számítógépes szaktanterem, ezeken az évfolyamokon bármilyen technológia-alapú iskolai mérést csak hordozható eszközökkel tudtak biztosítani (Higgins, Russell, \& Hoffmann, 2005). Mivel hazánkban az általános iskolákban már az 1990es években megjelent a számítástechnika tantárgy, így az iskolákat fel kellett szerelni számítógépes szaktantermekkel. Ezt követően pedig a 2000-es évek eleji Sulinet program keretében is jelentős infrastrukturális fejlesztések történtek az általános iskolákban (Körösné Mikis, 2002). Ezeket a termeket pedig már csak egy lépés volt az alsó tagozatos tanulók számítógépes tesztelésére is használni (R. Tóth \& Molnár, 2010). Jelenleg a hazai intézmények szinte döntő többsége a téttel nem rendelkező elektronikus tesztelésre alkalmas számítógépes eszközparkkal rendelkezik (Molnár \& Párszor-Kovács, 2015).

Az óvodák tekintetében ugyanakkor még továbbra is technikai korlátként merült fel a mérés-értékeléshez szükséges eszközök biztosítása, hiszen az óvodákban jellemzően kizárólag adminisztrációs céllal használnak egy-egy asztali számítógépet, így a mobileszközök óvodai elterjesztéséig a szélessávú internetkapcsolat igénye, vagy az óvodai csoportszobák vezetéknélküli internettel való ellátása sem merült fel (Fáyné Dombi, Hódi, \& Kiss, 2016). Az infokommunikációs eszközök óvodai nevelésben betöltött szerepéről és az ezzel kapcsolatos kihívásokról Fáyné és munkatársai (2016) készítettek összefoglaló tanulmányt, amelyben többek között kitérnek az óvodai online mérések témakörére is. Bár a digitális eszközök óvodában való pedagógiai célú felhasználására nemzetközi és hazai kezdeményezések is vannak, az iskolai számítógépes mérésekkel ellentétben annak elfogadottsága már sokkal vitatottabb. A szerzők részletesen ismertetik a hazai óvodák IKT-eszközökre vonatkozó tárgyi és személyi feltételeket, aminél jól körvonalazódik, hogy az óvodapedagógusok töredéke használja technológiát pedagógiai célból, az szinte kizárólag adminisztrációs céllal jelenik meg, igaz az elmúlt években több olyan kezdeményezés, fejlesztési projekt is volt, amely az óvodák és az óvodai csoportszobák digitális eszközökkel való felszerelését célozta meg. Azonban a mérésekhez szükséges infrastruktúra továbbra sem áll széleskörben rendelkezésre.

Napjainkban a nagymértékű technikai fejlődéssel együtt a technológia alapú mérésértékelésben rejlő lehetőségeket is egyre jobban ki lehet használni kisgyermekek körében is. Az olvasás kiváltható előre rögzített instrukciókkal, a feladatokat a kisgyermekek igényeihez alkalmazkodva lehet illusztrálni, azok megoldása manipulációval is történhet. Az utóbbi években több olyan kutatást is publikáltak, amelyek kisgyermekek tudásának technológia alapú mérését célozzák meg (Csapó \& Pásztor, 2015; Pásztor et al., 2017), köztük számolási készségek vizsgálatát is (Csapó, Molnár, \& Nagy, 2014). Az óvodai online mérés-értékelés 
lehetőségeinek feltárására vonatkozó hazai kutatások azonban csak az utóbbi pár évben kezdődtek el (Csapó et al., 2017; Rausch \& Pásztor, 2017). A kisgyermekkori technológia alapú mérések részletesebb eredményei egyelőre az első évfolyamos tanulók körében végzett kutatásokból származnak, amelyekben felmerülnek az ezzel kapcsolatos kihívások, hiszen a korábban ismertetett médiahatás fokozottan jelentkezhet a fiatalabb életkorú tanulók elektronikus tesztelése során. Ennek kiküszöbölésére már elindultak különböző kezdeményezések, Molnár és Pásztor (2015) egy olyan mérőeszközt fejlesztettek, amellyel ellenőrizhető, hogy a vizsgált gyermekek már képesek-e használni a számítógépet feladatok megoldásához, tudják-e pontosan kezelni a számítógépes egeret, illetve a billentyüzetet az online tesztelési környezetben megjelenő, változatos tartalmú és nehézségi szintű feladatoknál. Amint azt a szerzők is megemlítik, a megfelelő eszközhasználat képességének hiányában a mérések érvényessége jelentős mértékben sérülhet, és még frusztrálóvá is válhat a gyerekeknek. Az első vizsgálatok eredményei azt mutatják, hogy az elsős diákok többségének nem jelentett gondot a feladatok megoldása, valamint a jövőben adaptív fejlesztő tréninget állítanak össze azoknak a gyermekeknek, akiknél egyes feladatoknál még elmaradás tapasztalható ezen a téren, ezzel biztosítva azt, hogy a későbbiekben kitöltött tudásszintmérő és képességteszteken elért teljesítményüket ez ne befolyásolhassa negatívan.

Amennyiben az eszközhasználat nehézségeit sikerül leküzdeni, lehetőség nyílik az óvodás és iskolakezdő gyermekek széleskörü technológiai alapon történő mérésére. Csapó, Molnár és Nagy (2014) tanulmányukban az iskolaérettség számítógépes tesztelési lehetőségeit vizsgálták első évfolyamos tanulók körében. Ehhez összevetették DIFER tesztrendszer eredeti, szemtől szembeni és online tesztváltozatának eredményeit. Elemzéseik rávilágítottak arra, hogy egyes területeken számítógépes teszteléssel, a számos technikai előny mellett, megbízhatóbban lehet felmérni a tanulók teljesítményét (pl. beszédhanghallás), ugyanakkor az is kiderült, hogy azokon a területeken, ahol nem lehetséges megfelelően átültetni a feladatokat egy számítógépes platformra, kevésbé megbízható eredményeket kapunk. Az említett vizsgálatban a DIFER elemi számolási készség területe épp ilyen volt. Csak egyes részeit lehetett számítógéppel tesztelni (pl. manipulatív számolás), és a számítógépes mérés kevésbé bizonyult megbízhatónak, mint az eredeti szemtől-szembeni tesztváltozat. Ezért szükséges célirányosan technológia alapú mérési platformokra fejleszteni, figyelembe véve a technikai lehetőségeket, a válaszadás módját, kezelési felületet. A tesztfejlesztésnél pedig különösen fontos körültekintően eljárni, amikor kisgyermek számítógép alapú mérése a célunk (Pásztor, 2017; Rausch \& Pásztor, 2017). 


\section{4. Összefoglalás}

Ebben a fejezetben a digitális oktatási eszközök közül a technológia alapú mérés jellemzőit, és az abban rejlő lehetőségeket tekintettük át, miközben kitértünk azokra a kihívásokra, korlátokra is, amelyekkel infokommunikációs eszközökön keresztül végzett teszteléskor szembesülhetünk. Az utóbbi években rendkívüli módon felgyorsult technológiai fejlődés egyre nagyobb hatást gyakorol az oktatásra, és átalakítja a tanítás-tanulás korábbi rendszerét. A fejezet első részében röviden áttekintettük a technológiai fejlődés által indukált, iskola világát érintő változásokat. Ezt követően ismertettük a technológia alapú értékelés fogalmát, és bemutattuk, hogy milyen módon jelenik meg a pedagógiai értékelés különböző formáinál, illetve a nevelés-oktatás egyes szintjein. A fejezetben összegyüjtöttük azokat az újításokat, amelyek a számítógépes tesztelés hozott magával, emellett foglalkoztunk annak korlátaival, továbbá a médiahatás kérdésével is. Végül a kisgyermekkori elektronikus tesztelés sajátosságait, speciális kihívásait emeltük ki, ahol ismertettünk erre irányuló hazai kezdeményezéseket, valamint azok első tapasztalatait is. 


\section{A KUTATÁS CÉLJA, KÉRDÉSEI ÉS HIPOZÉSEI}

\subsection{A kutatás célja és relevanciája}

A dolgozat elméleti kereteiben összefoglaltuk a korai numerikus készségek összetevőit, azok fejlődését és szerepét az iskolai matematikatanulásnál. Bemutattunk olyan mérőeszközöket, amelyeket e készségek mérésére alkalmaznak nemzetközi és hazai viszonylatban, továbbá ismertettük a technológia alapú mérés-értékelés lehetőségeit és kihívásait, kitérve a kisgyermek elektronikus mérésére vonatkozó speciális kritériumokra. Az eredményes óvodai matematikai tapasztalatszerzéshez, iskolára való felkészüléshez, valamint később az iskolai matematikatanuláshoz elengedhetetlenek ezek a korai numerikus készségek, ezért különösen fontos időben észlelni az esetleges lemaradást, hogy az egyéni mérések eredményeire alapozva félzárkóztatást tudjunk biztosítani a gyermekeknek. A korai numerikus készségek, mint az iskolai matematikatanulás előfeltételei, szerves részét képezik a gyermekek iskolakészültségének (Csapó, Molnár, \& Nagy, 2014).

Az értekezésben részletesen bemutatásra kerülő online korai numerikus készségek teszt egy újgenerációs iskolakezdő mérőcsomag kidolgozására irányuló kutatási program (Csapó, Hódi, Kiss, Pásztor, Rausch, \& Molnár, 2017) részét képezi. Kutatásaink célja a gyermekek iskolakészültségének vizsgálatára alkalmas online tesztek kidolgozása óvodai-iskola átmenet időszakára. A kidolgozás alatt álló tesztcsomagban a szerző által kidolgozott korai numerikus készségek teszt mellett, az olvasás előkészségei (Kiss, Hódi, Tóth, \& B. Németh, 2016), induktív gondolkodás (Pásztor \& Molnár, 2016), feladattartás, vizuális memória, számítógépesegér-használat (Molnár \& Pásztor, 2015b), és zenei észlelési képességek (Asztalos, 2017) mérésére irányuló eszközök szerepelnek. Az iskolakezdő mérőcsomag kidolgozása szervesen illeszkedik a Szegedi Műhely több évtizedes mérőeszközfejlesztési kutatási irányultságába, ami a Nagy József által kidolgozott Preventív fejlettségvizsgáló rendszerrel (PREFER) kezdődött (Nagy, 1987), később pedig a Diagnosztikus Fejlődésvizsgáló Rendszer (DIFER) elkészítésével teljesedett ki (Nagy et al., 2004). Az utóbbi egy évtizedben a technológia alapú mérés-értékelés terjedése megindult az alacsonyabb korosztályok irányába, a technológiai fejlődés lehetőségeinek kiaknázása a hazai iskolaérettségvizsgálatok között is megjelent. Így jutottunk el jelen kutatásunk közvetlen előzményéhez, a DIFER elektronikus változatával végzett vizsgálathoz (Csapó, Molnár, \& Nagy, 2014).

Csapó, Molnár és Nagy (2014) tanulmányukban a DIFER egyes tesztjeinek (az írásmozgás koordináció és a szocialitás nem szerepelt a vizsgálatban) szemtől szembeni és számítógép-alapú változatát hasonlították össze. Miközben voltak olyan tesztek, például a 
DIFER beszédhanghallás tesztje, amelyek online formában megbízhatóbbnak bizonyultak, és a tesztfeladatokat jól át lehetett ültetni számítógépes platformra, az elemi számolási készség teszt nem bizonyult kellően megbízhatónak, a teszt reliabilitása 0,77 volt. Emellett a tesztet nem is lehetett eredeti formájában elektronikusan adminisztrálni, annak csak a manipulatív számolás és a számképfelismerés részei voltak felvehetők online.

Az értekezésben bemutatott kutatásunk során egy saját online mérőeszköz kifejlesztését céloztuk meg, amely segítségével gyorsan és megbízhatóan feltérképezhető az 5-7 éves gyermekek korai numerikus készségeinek fejlettsége az iskolakezdés időszakában. Munkánkban részletesen ismertetjük a tesztfejlesztés menetét, vizsgálatokhoz kidolgozott tesztváltozataink felépítését, és elemezzük az ezekkel végzett mérések eredményeit. A tesztfejlesztés ütemezését és kutatási tevékenységeinket a 3. táblázatban foglaltuk össze. Elemzéseink során részletesen kitérünk a teszt jóságmutatóinak bemutatására és kiértékelésére, megvizsgáljuk a teszteredményeket, azok eloszlását. A kutatás eredményeként egy olyan mérőeszköz jöhet létre, amelyet széles körben, könnyen tudnak majd alkalmazni óvodapedagógusok és tanítók a rájuk bízott gyermekek számolási készségeinek felmérésére és az esetlegesen lemaradásban lévő gyermekek kiszürésére, annak érdekében, hogy időben fel tudják őket zárkóztatni, illetve a mérések eredményire alapozva tervezhetik meg matematikai nevelö-oktató munkájukat.

\section{3. táblázat. A korai numerikus készségek teszt kidolgozásával és méréseivel kapcsolatos} tevékenységek ütemezése

\begin{tabular}{ll}
\hline \multicolumn{1}{c}{ Ütemezés } & \multicolumn{1}{c}{ Kutatási tevékenység } \\
\hline 2014. február - december & Szakirodalom feltárása, méröeszköz tervezése \\
2015. január - április & Tesztfeladatok kidolgozása (1. tesztváltozat) \\
2015. május - augusztus & Az első tesztváltozat véglegesítése és lektorálása \\
2015. szeptember & Iskolai próbamérés \\
2015. november & Óvodai próbamérés \\
2015. október - december & Iskolai nagymintás mérés \\
2016. február - április & Óvodai nagymintás mérés \\
2016. május & Iskolai nagymintás mérés (Nyomkövetés) \\
2016. június - október & 2. tesztváltozat kidolgozása \\
2016. november & Óvodai validációs mérés \\
2017. február - április & Óvodai nagymintás mérés \\
\hline
\end{tabular}

A tesztfejlesztés mellett a korai numerikus készségek fejlődését, valamint azok iskolai matematikatanulásra gyakorolt hatását is fel kívántuk térképezni. Végeztünk méréseket óvodai 
és iskolai korcsoportokon, így keresztmetszeti összehasonlítást is tudunk végezni. A keresztmetszeti vizsgálatok eredményei az óvoda-iskola átmenet számolási készségek fejlődésének időszakáról nyújtanak átfogó képet. Emellett az első évfolyamos mintán longitudinális nyomkövetésre is lehetőségünk volt, amelynek keretében a tanévkezdéskor felvett számolási tesztünk adatait vethettük össze a tanulók évvégi matematika teszten elért eredményeivel. Ennek köszönhetően azonosítható, hogy az általunk vizsgált korai numerikus készségek a matematika mely részterületére vannak leginkább hatással, továbbá a teszt prediktív validitásáról is információval szolgálnak. Ugyanakkor a méréseken résztvevő óvodások és iskolások mintájáról kevés háttérváltozóval rendelkezünk, amely így szükíti elemzéseink körét, és korlátozza eredményeik mélyebb értelmezését ezen a területen.

Saját fejlesztésű korai numerikus készségeket vizsgáló tesztünket, amely már eleve elektronikus felületre készült 2014-ben kezdtük el kidolgozni. Az új teszttel végzett első mérésekre 2015-ben került sor, majd a 2015 őszi és 2016 tavaszi méréseink után alaposan átdolgoztuk a mérőeszközünket, így jött létre a második tesztváltozat. 2016 őszétől már az átdolgozott tesztet alkalmaztuk a kisgyermekek körében végzett vizsgálatainkhoz.

\subsection{Kutatási kérdések}

Kutatásunk fö céljának megfelelően, kutatási kérdéseink elsősorban a korai numerikus készségek online mérésére alkalmas eszköz fejlesztéséhez kapcsolódnak. Továbbá, a mérőeszköz szerkezetéhez és müködéséhez is kapcsolódva vizsgáltuk a korai numerikus készségek fejlődését, valamint e készségek az iskolai matematikai teljesítményre gyakorolt hatását. Mindezekkel összefüggésben a következő kérdéseket fogalmaztuk meg:

1. Megbízhatóan mér-e a korai numerikus készségek teszt? Milyen a teljes teszt és az altesztek reliabilitása? Elfogadhatóak-e az egyes itemek elkülönítésmutatói a teljes teszt és a résztesztek tekintetében?

2. Megerösítő faktorelemzéssel igazolható-e a teszt konstruktum-validitása? Hogyan illeszkednek az egyes itemek a résztesztek faktoraihoz?

3. Milyen az egyes feladatok nehézségi indexe, milyen képességszinteket fed le a teszt?

4. Kitöltők a teszten és a részteszteken elért átlagos teljesítményének eloszlása megegyezik-e a normál eloszlással?

5. Milyen a korai numerikus készségek teszt, a résztesztek és az egyes itemek prediktív validitása? 
6. Milyen átlagos teljesítményt értek el a gyermekek óvodában és első évfolyamon a korai numerikus készségek teszten, illetve annak résztesztjein?

7. Milyen mértékü fejlődés tapasztalható a vizsgált óvodás és iskolás korcsoportok között?

8. Milyen mértékben befolyásolja a gyerekek teszteredményét a számítógéphasználati és tablet-használati jártasságuk?

9. Milyen hatással van az első évfolyamos tanulók tanévkezdéskor mért korai numerikus készségének fejlettsége a tanév végi matematika teljesítményükre?

\subsection{Hipotézisek}

Kutatásunk hipotéziseit a kutatási kérdésekhez kapcsolódóan fogalmaztuk meg, és azok sorrendjének megfelelően vázoljuk fel. Feltételezéseinket a dolgozat elméleti hátterében ismertetett szakirodalmi feltárásunkra alapozzuk.

\section{Hipotézisek:}

H1. A teszt és résztesztjeinek reliabilitása a megfelelő, az megbízható becslést ad a korai numerikus készségek fejlettségéről.

H2. A teszt konstruktum-validitása megfelelö, a teszt egyes itemei jól illeszkednek a teszt és résztesztjeinek konstruktumához.

H3. Feltételezzük, hogy a tesztfeladatok óvodában és iskolában is lefedik az alacsonyabb és magasabb képességszinteket.

H4. A teszt tartalmi összetevői alapján feltételezzük, hogy a teszt és a résztesztek eloszlása az óvodás korcsoportban megegyezik a normál eloszlással, ugyanakkor feltételezzük, hogy az eloszlások jobbra tolódnak az első évfolyamos tanulók esetében.

H5. Feltételezzük, hogy a korai numerikus készségek teszt, résztesztjei, itemei és az első évfolyam végi matematika teljesítmény között szignifikáns korreláció van.

H6. Feltételezzük, hogy az óvodai korcsoportban alacsonyabb átlagteljesítmény és magasabb szórás, míg az első évfolyamos tanulók teljesítménye magasabb és egyben alacsonyabb szórással rendelkezik.

H7. Az óvodás és az iskolás korcsoportok között szignifikáns fejlődés mutatható ki a korai numerikus készségeik terén.

H8. Feltételezzük, hogy a gyermekek számítógéphasználati és tablet-használati jártassága nincs jelentős hatással a teljesítményükre.

H9. Szakirodalmi feltárásunk alapján feltételezzük, hogy a tanulók tanév eleji korai numerikus készségeinek fejlettsége jelentős mértékben meghatározza a tanulók iskolai matematikatanulását és ezáltal a tanév végi matematika teljesítményüket. 


\section{MÓDSZEREK}

\subsection{Vizsgálataink mintái}

Vizsgálatainkat óvodás és általános iskola első évfolyamos gyermekek körében végeztük. Óvodai vizsgálataink közül az első és második mérés az SZTE Oktatáselméleti Kutatócsoport és az MTA-SZTE Képességfejlődés Kutatócsoport online iskolakezdő mérőcsomag fejlesztéséhez kapcsolódóan, a kutatócsoport által szervezett óvodai mérések keretei között valósultak meg. Az óvodai validációs mérés saját szervezésben, a Pallasz Athéné Egyetem Pedagógusképző Kar gyakorló óvodáinak részvételével valósult meg. Iskolai méréseink az MTA-SZTE Képességkutatócsoport Longitudinális vizsgálatainak VI. mintáján végeztük (Csapó, 2014), amely országos területi reprezentativitási szempontokat figyelembe véve lett kialakítva. Óvodai és iskolai méréseink mintáinak főbb jellemzőit a 4. táblázatban foglaltuk össze. Vizsgálataink során a résztvevők számára nagyfokú anonimitást biztosítottunk, amelynek következtében a fejezetben ismertetett háttérváltozókon, a gyerekek nemén és életkorán kívül más jellemzőiről nem rendelkezünk információval.

4. táblázat. Vizsgálataink mintái - nemek szerinti megoszlások, átlagélekor

\begin{tabular}{lccccc}
\hline \multicolumn{1}{c}{ Mérés } & $\begin{array}{c}\text { Fiú } \\
(\mathrm{N})\end{array}$ & $\begin{array}{c}\text { Lány } \\
(\mathrm{N})\end{array}$ & $\begin{array}{c}\text { Összesen } \\
(\mathrm{N})\end{array}$ & $\begin{array}{c}\text { Átlagéletkor } \\
(\text { év) }\end{array}$ & $\begin{array}{c}\text { Szórás } \\
\text { (év) }\end{array}$ \\
\hline $\begin{array}{l}\text { 1. óvodai mérés } \\
\text { 2. óvodai mérés }\end{array}$ & 176 & 166 & 342 & 5,78 & 0,75 \\
$\begin{array}{l}\text { Óvodai validációs mérés } \\
\text { 1. iskolai mérés }\end{array}$ & 15 & 126 & 252 & 6,41 & 0,52 \\
$\begin{array}{l}\text { (longitudinális 1) } \\
\begin{array}{l}\text { 2. iskolai mérés } \\
\text { (longitudinális 2) }\end{array}\end{array}$ & 2614 & 2540 & 5154 & 7,09 & 0,48 \\
\hline
\end{tabular}

Megjegyzés. A 2. iskolai mérés mintája az 1. iskolai mérés részhalmaza.

\section{Az első óvodai mérés mintája}

Az első óvodai mérésünkbe az önkormányzat fenntartásában álló Szeged Megyei Jogú Város Óvodák Igazgatóságának tagintézményeit vontuk be. A vizsgálatban így belvárosi és külvárosi óvodák egyaránt részt vettek, ugyanakkor a minta kiválasztásában reprezentativitási szempontok nem játszottak szerepet, azt elsődlegesen az intézmények elérhetősége határozta 
meg. A tesztet kitöltő gyermekek átlagéletkora 5,8 év volt, a legfiatalabb résztvevő 4 év 3 hónapos, a legidősebb 7 év 4 hónapos volt. A mintában a nemek aránya megegyezett $\left(\chi^{2}=0,29\right.$; $\mathrm{p}=0,59)$.

\section{A második óvodai mérés mintája}

A második óvodai mérés ismét szegedi óvodák részvételével zajlott, az első óvodai méréssel megegyező módon. A vizsgálatban összesen 242 óvodás vett részt, átlagéletkoruk 6,4 év volt. A legfiatalabb mérésben résztvevő gyermek 5 év 4 hónapos, a legidősebb 8 év 1 hónapos volt az adatfelvétel idején.

\section{Az óvodai validációs mérés mintája}

Az óvodai validációs vizsgálat két kecskeméti óvodában zajlott, mindkét óvoda belvárosi elhelyezkedésü és a Neumann János Egyetem fenntartásában áll (az adatfelvétel idején: Pallasz Athéné Egyetem). Az óvodák kiválasztását azok elérhetősége határozta meg. A két tagintézménybe járó, 5 és 6 év közötti életkorú gyermekek közül összesen 30 gyermeket választottunk ki véletlenszerűen. A mintában nemek aránya azonos volt, 15 fiú és 15 lány vett részt a mérésen. A gyermekek átlagéletkora 5,7 év volt, a legfiatalabb 5 év 4 hónapos a legidősebb 6 éves volt.

\section{Az iskolai mérések mintája}

Iskolai longitudinális vizsgálatunk első mérésében összesen 5154 első évfolyamos tanuló vett részt, 166 általános iskola 275 osztályából. A tesztet 2614 fiú és 2540 lány töltötte ki, a nemek aránya megegyezett $\left(\chi^{2}=3,77 ; \mathrm{p}=0,052\right)$. A tanulók átlagéletkora az első mérés alkalmával 7,1 év volt. Adatbázisunk szerint a legfiatalabb kitöltő 5 év 11 hónapos, a minta legmagasabb életkora pedig 10 év 2 hónap. A magas terjedelmet egy 10 éves gyermeknek köszönhetjük, kizárását azonban magas életkora miatt nem tartottuk indokoltnak, a minta átlagéletkorának szórása alacsony volt. A második iskolai mérésen, amely a longitudinális vizsgálat második mérési pontja volt, összesen 4277 olyan első évfolyamos tanulót értünk el, akik részt vettek az első adatfelvételen. A tanév végi mérésen a nemek aránya nem változott, a résztvevők átlagéletkora 7,7-re emelkedett. 


\subsection{Eszközök}

Kutatásunk során a saját fejlesztésű eszközök mellett mindegyik óvodai és az iskolai bemeneti mérésen alkalmaztuk a Tablet-eszközhasználat, illetve Számítógépes-egér használat tesztet (Molnár \& Pásztor, 2015a). Az óvodai validációs mérésnél a DIFER tesztrendszer (Nagy et al., 2004b) két tesztjét, az elemi számolási készség és a relációszókincs teszteket vettük fel. A longitudinális vizsgálat második mérési pontján egy matematika teljesítménytesztet alkalmaztunk. A vizsgálatok eszközeinek áttekintéséhez az 5. táblázat ad átfogó képet. A következőkben ismertetjük a tesztfejlesztés menetét, a korai numerikus készségek teszt két változatának felépítését, valamint részletesen bemutatjuk az összes általunk alkalmazott mérőeszközt.

\section{5. táblázat. Vizsgálataink eszközei}

\begin{tabular}{lc}
\hline \multicolumn{1}{c}{ Meres } & Eszközök \\
\hline 1. óvodai mérés & Tablet-eszközhasználat teszt \\
& Korai numerikus készségek teszt (1. tesztváltozat) \\
2. óvodai mérés & Tablet-eszközhasználat teszt \\
& Korai numerikus készségek teszt (2. tesztváltozat) \\
& Tablet-eszközhasználat teszt \\
Óvodai validációs mérés & Korai numerikus készségek teszt (2. tesztváltozat) \\
& DIFER Elemi számolási készség teszt \\
1. iskolai mérés & DIFER Relációszókincs teszt \\
(longitudinális 1) & Számítógépes-egér használat teszt \\
2. iskolai mérés & Korai numerikus készségek teszt (1. tesztváltozat) \\
(longitudinális 2) & Matematika teljesítményteszt \\
\hline
\end{tabular}

\subsubsection{A korai numerikus készségeket vizsgáló teszt kialakítása}

A tanulmányunk elméleti fejezeteiben is bemutatott tesztek, tesztrendszerek, korábbi kutatásokban használt mérőeszközök elemzését követően készítettük el saját online mérőeszközünket. Saját eszközünk kidolgozásakor több tudományos és technikai jellegü szempontot is mérlegeltünk. Bár kiindulási pontnak tekintettük az iskolai matematikatanuláshoz szükséges készségek lefedését, célunk egy automatikus kiértékelést és azonnali visszacsatolást biztosító online mérőeszköz kidolgozása volt, így a technikai korlátok 
miatt nem volt lehetséges e készségek pontos és teljes lefedése. Ezen kívül a megcélzott korosztály sajátosságait is figyelembe kellett vennünk, így különösen ügyeltünk a tesztelés idejére, a feladatok mennyiségére és kinézetére (Rausch, 2016b; Rausch, 2017).

\section{A teszt tartalmi keretei, nehézsége}

Tesztünk fő komponenseit, tartalmát és nehézségét az iskolaelőkészítés és iskolakezdés időszakára, 5-7 éves életkorú gyermekekre optimalizáltuk. Ebben az időszaknak a gyermekek számolási készségei jelentős fejlődésen mennek keresztül, és az iskolakezdéskori fejlettség később sok szempontból is meghatározó lesz (Aunio és Niemivirta, 2010; Aunola, et al., 2004).

A verbális számolási készségek fejlődéséhez a gyermekek először a számok nevét sajátítják el. A gyermekek azok sorrendjét is elkezdik megtanulni már öt éves koruk előtt, bár nagyjából négy éves korukig ez mondókaszerü ismeretet jelent. Tesztünkben e készségek fejlődésével elsősorban az elemi számolásnak nevezett terület foglalkozik, amely a nemzetközi szakirodalomban number word sequence-ként ismert fogalom, a számok megfelelő előrefelé és visszafelé sorrendjének pontos tudását, beleértve a számkörök átlépését jelenti. Ez a terület fontos alapja a számolási készségeknek, elemi számolási mủveletek végzésének, amely nélkül elképzelhetetlen az összeadás, kivonás megtanulása az iskolában (Aunio \& Räsänen, 2016). A mennyiségekkel végzett számolási műveletek, a számlálási készségek nélkülözhetetlen összetevői a korai matematikai készségeknek, melyek a kardinális számok fogalmával összekapcsolódva képezik az iskola alsó tagozatában tovább fejlődő aritmetikai készségek alapját (Aunio és Niemivirta, 2010).

$\mathrm{Az}$ arab számok felismerése és hangos leolvasása a hazai szakirodalomban számolvasásként jelenik meg (Józsa, 2014). Mivel online tesztünkben a számolvasást nem tudtunk mérni, azért egyik résztesztünk az arab számok felismerését vizsgálja, számkártyákon lévő egy-, két- és háromjegyű számokat kell a tanulóknak felismerni. Annak érdekében, hogy azt is mérjük, hogy tisztában vannak-e ezek jelentésével, egy másik résztesztben az arab számok mennyiségekhez való rendelését is vizsgáltuk.

A korai numerikus készségek a disszertáció elméleti fejezeteiben bemutatott összetevőinek teljes lefedésére az online mérés-értékeléssel foglalkozó fejezetben korábban már ismertetett korlátok miatt nem volt lehetőségünk. A teszt kialakításakor azonban törekedtünk arra, hogy minél szélesebb körből merítsünk, és a megvalósítható feladatoktípusokat, technikai adottságokat maximálisan kihasználjuk. Tesztfeladatainkban különböző számképek, mennyiségek, arab számok felismerése, a képernyőn megjelenő 
rajzokkal, képekkel végezhető manipulatív számolási műveletek egyaránt megjelennek, ugyanakkor a gyermekek beszéltetéséről, a hangos számolásról az elemi számolás részteszt esetében, és a hangos számolvasás vizsgálatáról sajnos le kellett mondanunk.

\section{A tesztfeladatok kialakitása, kinézete}

A teszt megszerkesztéséhez és felvételéhez az SZTE Oktatáselméleti Kutatócsoportja által, a Diagnosztikus Mérések Fejlesztése kutatási projekt keretében kifejlesztett eDia online mérésértékelési platformot használtuk (Csapó \& Molnár, 2017; Molnár, 2015; Molnár, Papp, Makay, \& Ancsin, 2015). A rendszer segítségével biztosított volt az azonnali kiértékelés és visszacsatolás.

A tesztfeladatok kinézetének megalkotásakor fontos szempont volt az esztétikus megjelenés, hogy azok vonzzák a kisgyermekek figyelmét, továbbá törekedtünk a változatosságra is, hogy a megszerzett figyelmet a tesztelés során fenn tudjuk tartani. Ezt a fontos szempontot mégis a letisztultsággal és a feladatképek tényleges céljával és funkciójával kellett összehangolnunk. Fontos volt, hogy minden kép, illusztráció a feladatok megoldásához, az instrukció megértéséhez, vagy a válaszadáshoz kapcsolódjon. A felesleges, a feladathoz kevésbé kapcsolódó, inkább csak a figyelmet elterelő illusztrációkat mindvégig mellőztük. Emellett az egymáshoz hasonló elrendezésű, hasonló képeket megjelenítő feladatok hátterének színét módosítottuk sárga, kék és lila színüre, amelyek váltakoztak, így is felismerhetővé tettük másik feladatról van szó. Az első tesztváltozat dichotóm feladatainál kerültük a zöld és piros háttérszínek használatát, nehogy az befolyásolja a tanulók válaszát. Az arab számok ábrázolásánál törekedtünk jól olvasható, kerekített karakterek megjelenítésére, így az Arial Rounded betűtípusra esett a választásunk. A számkártyákon képként megjelenő arab számok mérete 75-80-as betűméretnek felelt meg.

A tesztfeladatok képernyőn megjelenő elrendezésében három elem, más online tesztekhez hasonlóan (Pásztor, 2017; Török, Hódi, \& Kiss, 2016), mindig egységesen jelent meg: a „hangszóró” gomb, amellyel a tanulók az instrukciót újra meg tudták hallgatni, valamint a következő, illetve az előző feladatra lépést szolgáló „tovább” és ,vissza” gombok, amelyekre egy-egy nyilat helyeztünk el. A hangszóró gomb mindig a képernyő bal felső sarkában jelent meg, a tovább- és visszalépést szolgáló nyilak pedig a bal és jobb alsó sarokban.

A feladatokban megjelenő képeket igyekeztünk a lehetőségekhez mérten jó minőségben, fájlméretük miatt, mégis kisebb felbontásban beilleszteni. A képernyőn böngészőben megjelenő tesztfeladat 1024×768 képpontot foglalt el, a képeinket is ehhez a 
felbontáshoz igazítottuk a teljes méretböl elfoglalt területükhöz mérten. Emellett a válaszadásra szolgáló vonszolással mozgatható képek, valamint a célterületek méretére és formájára is ügyeltünk, hogy a gyermekek számára minél könnyebb legyen, akár egér, akár az ujjuk használatával a kért müvelet elvégzése.

A feladatok szövegének megfogalmazásakor törekedtünk a minél rövidebb, pontosabb és a megcélzott életkorú gyermekek számára egyértelmü, jól érthető utasításokra. Az instrukciók lektorálásában régóta pályán lévő pedagógusok is részt vettek. A tesztfeladatok általunk kidolgozott instrukcióit, és a válaszadás módját is áttekintettük közösen a teszt fejlesztésekor. A képernyőn szöveges formában nem jelenítettük meg utasításokat, azokat a tanulók csak fejhallgatón keresztül hallgatták. Így szándékoztuk elkerülni a gyermekek olvasási készségeinek befolyását a teszten elért teljesítményre, beleértve azokat a gyerekeket is akik már tanulják az olvasást, de annak kezdeti szakaszán a tesztben megjelenő szövegek a figyelmüket elterelhették volna. Az instrukciók felmondására egy szakképzett és tapasztalt narrátort kértünk fel mindkét tesztváltozat esetében.

\section{Próbamérések}

A dolgozatban részletesen bemutatott és kielemzett vizsgálatokra több próbamérést követően került sor. Az iskolai pilot mérésünkre 2015. szeptember első felében került sor összesen kilenc Csongrád megyei általános iskola bevonásával. Ebben 219 első évfolyamos tanuló vett részt, és az első tesztváltozat előzetes, 46 itemből álló verzióját mértük be. Bár a teljes teszt megbízhatósága elfogadható volt $($ Cronbach- $\alpha=0,86)$, egyes résztesztek, például az elemi számolás (Cronbach- $\alpha=0,52)$, elemi müveletvégzés (Cronbach- $\alpha=0,54$ ) szintjén jelentős átdolgozásra volt szükség. Az iskolai mérések során az iskolák pedagógusai mellett a személyesen is felügyeltük az adatfelvétel lebonyolítását. Megfigyeléseinket, valamint a tanulóktól és a pedagógusoktól kapott visszajelzéseket is felhasználtuk az átdolgozáshoz.

Óvodai próbamérésünkre (Rausch, 2016a) már az első tesztváltozat javított verziójával, 2015 novemberben került sor egy szegedi óvoda 5 és 6 éves óvodásainak bevonásával $(\mathrm{N}=91)$. A teszt felvételét itt is személyesen felügyeltük. Továbbra is fontosnak tartottuk, hogy a teszt felvételét követő kvantitatív elemzések mellett az adatfelvétel folyamatát a megfigyeléssel is kiegészítsük, amit felhasználva tudunk javítani az eszközön. Az eszköz javított, 42 itemes verziója valamivel megbízhatóbb volt óvodában (Cronbach- $\alpha=0,86$ ), és a résztesztek reliabilitása sem volt 0,6 alatt. A gyengébbnek bizonyult részteszteket a végső, a későbbiekben részleteseb bemutatatott 1 . óvodai mérésnél újabb itemekkel egészítettük ki (1. Melléklet). 


\subsubsection{Kutatásunk során kifejlesztett korai numerikus készségeket mérő eszközök}

\section{Az Online Korai Numerikus Készségek Teszt elsö tesztváltozata}

A mérőeszköz első változata számolási készségeket, számok helyes sorrendjének ismeretét, különböző mennyiségekkel végzett számolási műveleteket, számképek, arab számok felismerését, összességében a korai numerikus készségeket vizsgálta. A tesztben hat részterület szerepelt (Mennyiségek és számok, Elemi számolás, Relációk, Elemi műveletek, Arab szám felismerés, Arab számok és mennyiségek kapcsolata). Az első változat iskolában összesen 47, óvodában, 5 feladattal kibővítve, 52 itemből tevődött össze (1. Melléklet).

A mennyiségek és számok résztesztben a gyermekeknek egy az instrukcióban hallott mennyiséget kellett kiszámolniuk, illetve felismerniük. Három feladat 10-es számkörön belüli mennyiségek kiszámolását mérte, ezeket a feladatokat a gyerekek vonszolással (drog and drop) tudták megoldani (12. ábra), nagyobb mennyiség esetén három kép közül tudták kiválasztani azt a képet, amelyiken a hallott mennyiségü rajz (pl. virág) szerepelt (13. ábra).

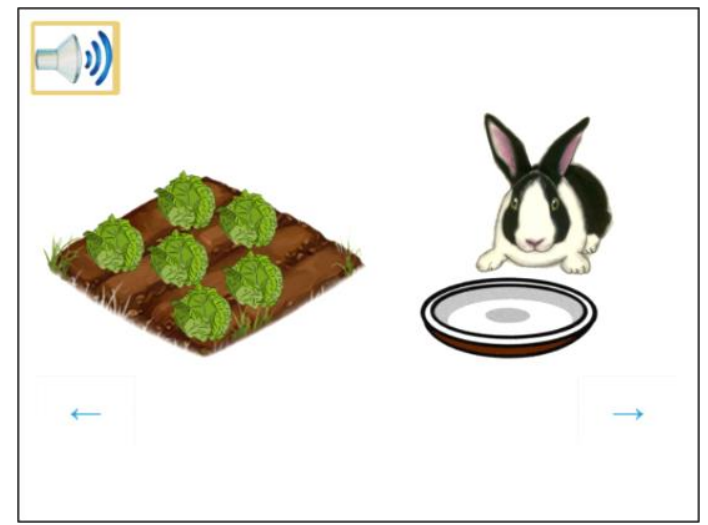

12. ábra

Példafeladat a mennyiségek és számok résztesztböl. Instrukció: „Húzz két káposztát a nyuszi tányérjára!”

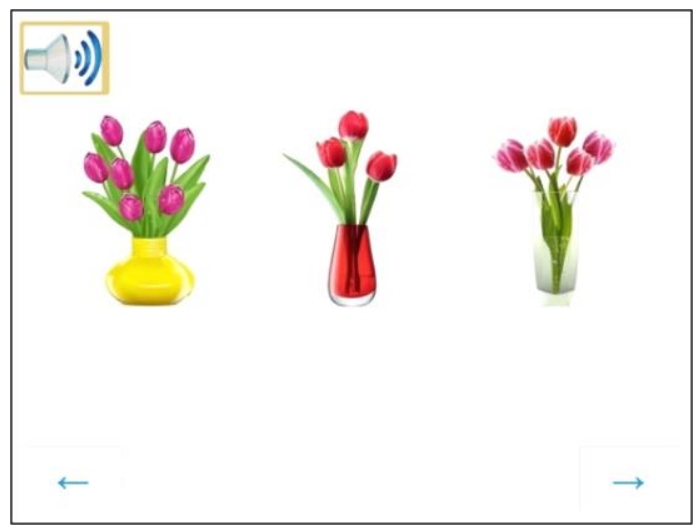

13. ábra

Példafeladat a mennyiségek és számok résztesztböl. Instrukció: „Kattints arra a vázára, amelyikben öt tulipán van!"

Az elemi számolás részterületnél zártvégü, dichotóm feladatokkal mértük az 1-től 21-ig számolás, a számkörök átlépésének és visszafelé számolás készségét. A feladatok fokozatosan egyre magasabb számkörökre vonatkoztak. Az első számsorok a 20-as számkörön belül voltak, majd a 30-as, 50-es és 100-as számkörök átlépése következett. A feladatblokk végén kerültek sorra a visszafelé számolást mérő feladatok, elsőként szintén 20 -as számkörön belül, majd a feladatok az elörefelé számoláshoz hasonlóan szintén egyre magasabb számkörökre vonatkoztak, egymást követően a 30 -as, 50-es és 100-as számkörök visszafelé történő átlépése következett. A résztesztben nem a gyermekek hangos számolását értékeltük, hanem annak 
felismerését tudtuk vizsgálni, hogy a narrátor által elmondott számsor, számkör átlépés helyesnek, vagy helytelennek találták-e. Miután meghallgatták az adott számsort kattintással válaszoltak. Amennyiben helyes számsort hallottak egy zöld pipára, ha szerintük hibás volt a számsor egy piros x-re kellett kattintaniuk. A helyes és helytelen számsorok egymást követő sorrendjét véletlenszerüen alakítottunk ki, mivel a feladatblokkban egymást követő feladatok kinézetre megegyeztek, a feladatok háttérszínét folyamatosan változtattuk (14-15. ábra).

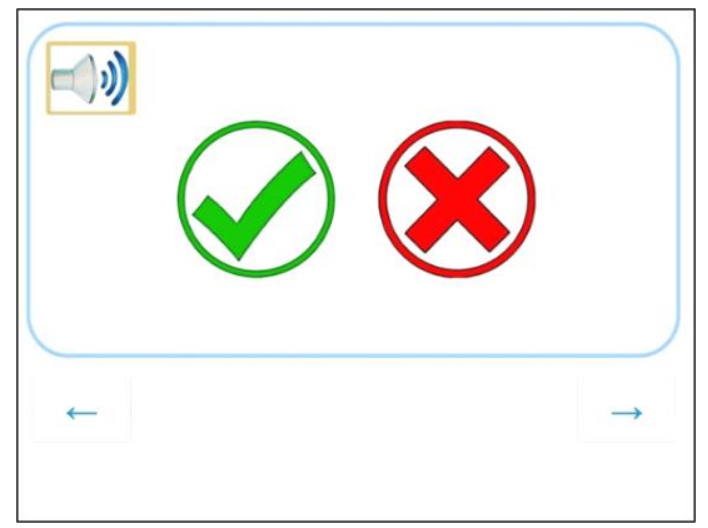

14. ábra

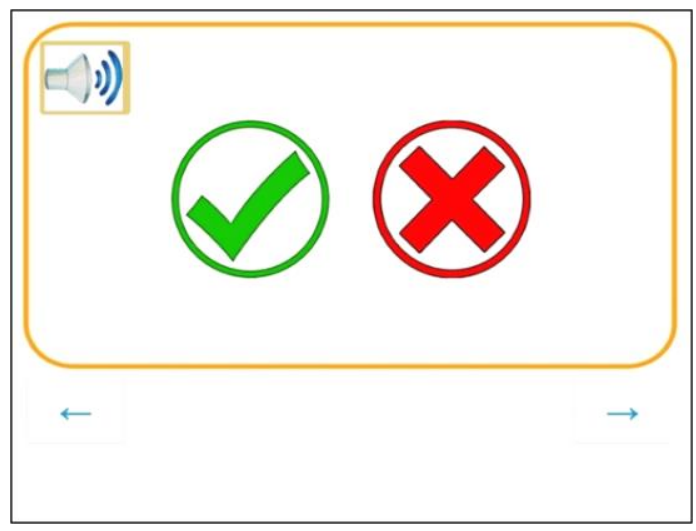

15. ábra

Példafeladat az elemi számolás résztesztböl. Instrukció: „,Most negyvennyolctól kezdek el számolni. Figyeld meg, hogy helyesen számolok-e! 48, 49, 50, 51, 52, 53."

Példafeladat az elemi számolás résztesztböl. Instrukció: ,,Visszafelé számolok ötvenegytöl. Figyeld meg, hogy helyesen számolok-e $51,50,39,38,37,36 . "$

A relációk résztesztben különféle mennyiségü és összetételü halmazok közül kellett kiválasztaniuk az instrukció szerint megfelelő képet. A feladatok egy részében két halmazból választották ki a több, vagy kevesebb elemet tartalmazót (16. ábra), valamint három kép közül a két egyforma mennyiséget reprezentáló képet (17. ábra). A résztesztnél válaszaikat a megfelelő képre, képekre kattintva adhatták meg. Ezek mellett a feladatblokk második felében mennyiségek növekvő és csökkenő sorba rendezését is kértük a gyerekektől, ezeket a feladatokat vonszolással oldották meg.

Az elemi müveletvégzés résztesztben a gyermekek 20-as számkörön belüli mennyiségekkel végeztek manipulatív számolási feladatokat. Az ehhez a részhez tartozó feladatokban különböző műveleteket vizsgáltunk, a gyermekek a kapott utasítások alapján kellett kiszámolni, kiegészíteni, kivonni, és részhalmazokra bontani a feladatokban megjelenő képeket. A feladatokat minden esetben vonszolással oldhatták meg, a képernyőn megjelenő képeket, rajzokat az instrukciónak megfelelően rendezték, azokat a kért célterületre mozgatták (18-19. ábra). 


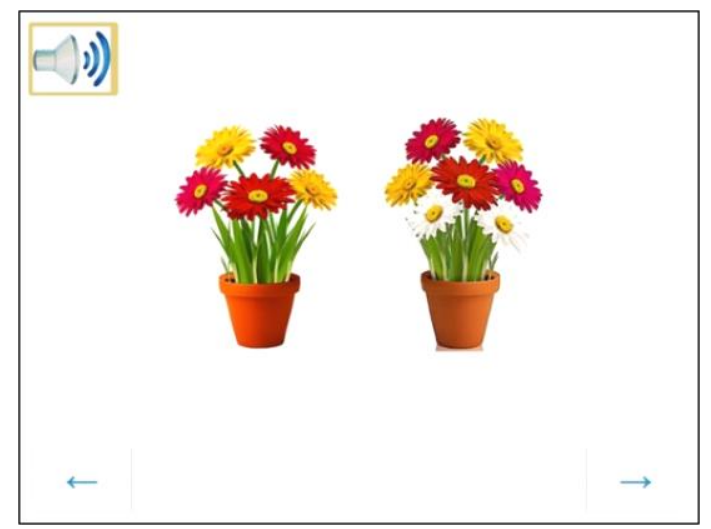

16. ábra

Példafeladat a relációk résztesztböl.

Instrukció: „Melyik cserépben van több virág? Kattints rá!"”

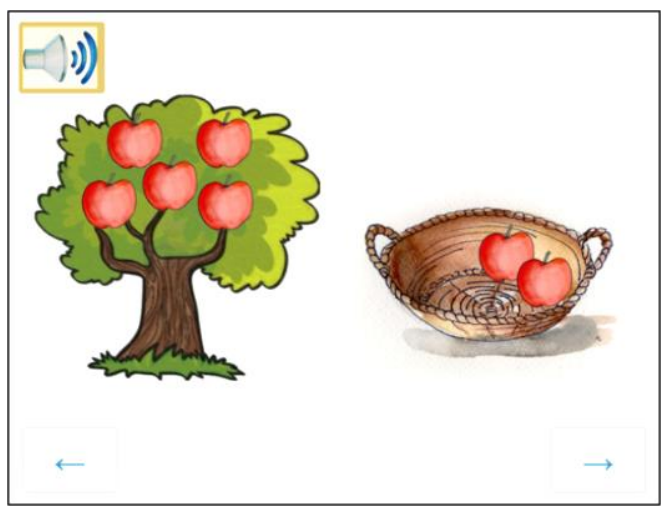

18. ábra

Példafeladat az elemi müveletvégzés résztesztböl. Instrukció: „A kosárban most két alma van. Húzz annyi almát a kosárba, hogy összesen öt legyen benne!"

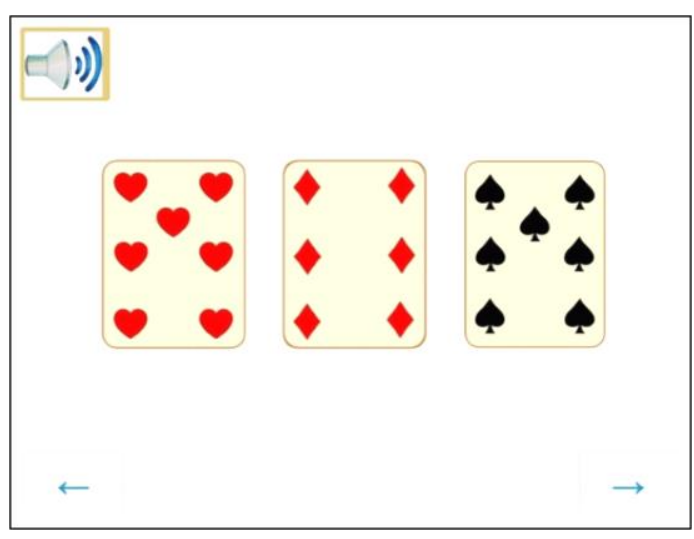

17. ábra

Példafeladat a relációk résztesztböl. Instrukció: „Kattints arra a két kártyára, amelyeken ugyanannyi rajz van!”

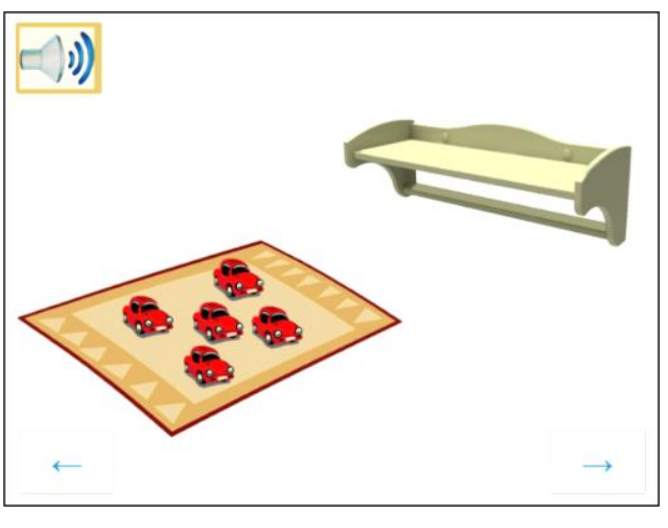

19. ábra

Példafeladat az elemi müveletvégzés résztesztböl. Instrukció: „A szönyegen most öt kisautó van. Húzz annyit a polcra, hogy három maradjon a szönyegen!"

Az arab számok felismerése részterület feladatainak megoldása során a tanulóknak négy arab számkártya közül tudták kiválasztani azt a számot, amit az instrukcióban a fejhallgatón keresztül hallottak. Válaszukat a képernyőt kivetített négy kártya valamelyikére kattintva adhatták meg. A feladatok fokozatosan nehezedtek, az első két feladatban két egy jegyü szám (20. ábra), majd két kétjegyü szám következett (21. ábra), végül két három jegyü számot ábrázoló feladat került sorra. 


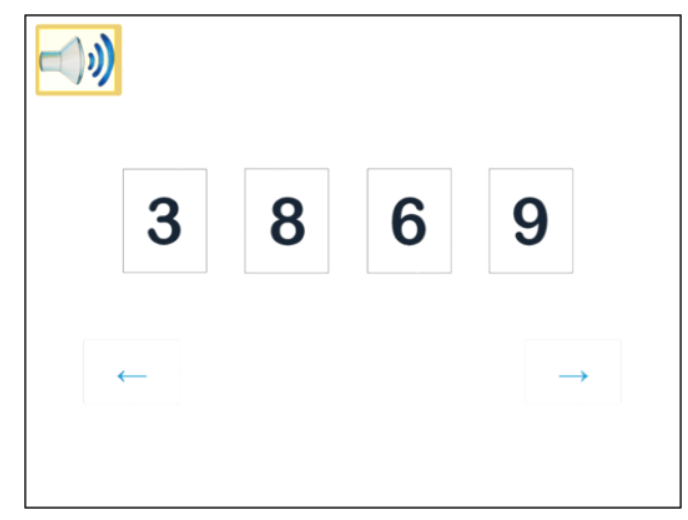

20. ábra

Példafeladat az arab számok felismerése résztesztböl. Instrukció: „,Mondok egy számok. Keresd meg a kártyák között és kattints rá! Három."

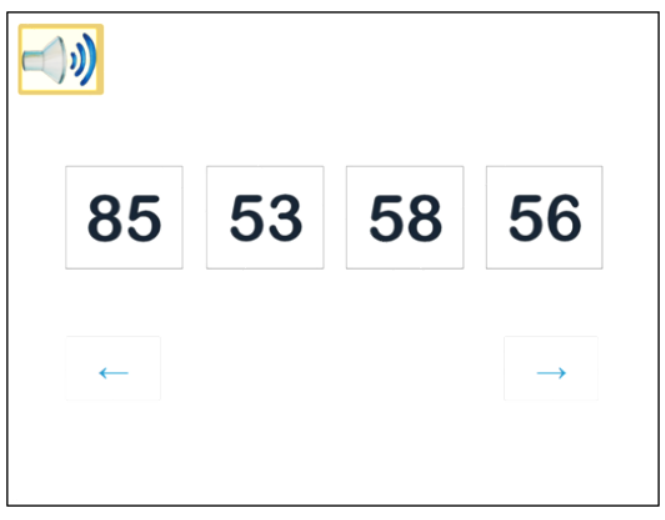

21. ábra

Példafeladat az arab számok felismerése résztesztböl. Instrukció: „Mondok egy számok. Keresd meg a kártyák között és kattints rá! Ötvennyolc."

Arab számok és mennyiségek kapcsolatára vonatkozó részterület feladataival a mennyiségek és arab számok közötti kapcsolatok ismeretét vizsgáltuk. Az ehhez a részhez tartozó feladatblokk első felében vonszolással lehetett kirakni a feladatban egy kártyán látott arab számhoz tartozó mennyiségeket, a részteszt második felében egy képen látott mennyiséghez kellett párosítani a megfelelő arab számot négy lehetőség közül (22-23. ábra).

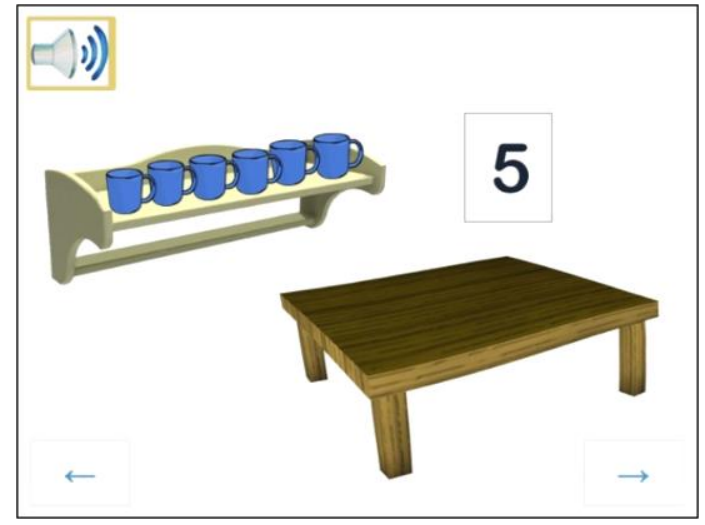

22. ábra

Példafeladat az arab számok és mennyiségek résztesztböl. Instrukció: „A kártyán egy számot látsz. Húzz annyi bögrét az asztalra, amennyit a kártyán lévő szám mutat!"

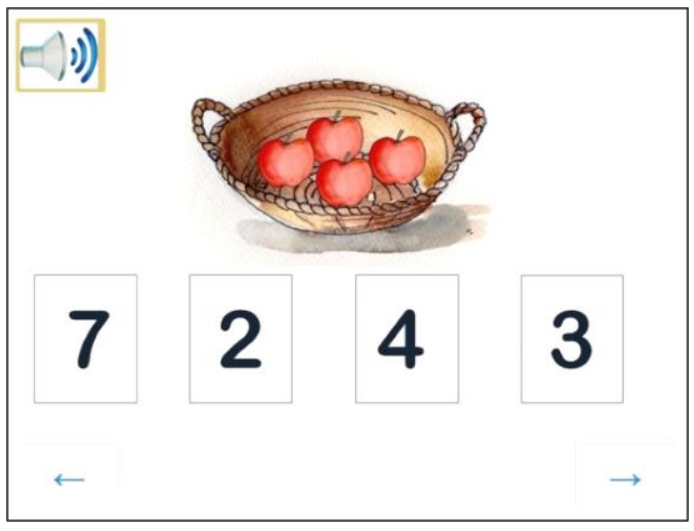

23. ábra

Példafeladat az arab számok és mennyiségek résztesztböl. Instrukció: „Kattints arra a számra, ahány alma van a kosárban!" 


\section{Az Online Korai Nnumerikus Készségek Teszt második tesztváltozata}

Az általunk kidolgozott második tesztváltozat kialakításához az első változattal végzett óvodai és iskolai mérések eredményei és tapasztalatai vezettek (Rausch, 2016a, 2017). Az új tesztváltozat itemeinek száma változott, a második változat összesen 40 feladatból áll. Az átdolgozás során azokra az összetevőkre kezdtük helyezni a hangsúlyt, amelyek online is megbízhatóan és érvényesen mérnek, továbbá erős előrejelző erővel bírnak a későbbi iskolai matematikatanulás szempontjából, ezt a szempontot a magasabb képességszintü tanulók mérésére alkalmas feladatok beépítése is kiegészítette.

$\mathrm{Az}$ új tesztváltozatban a legszembetűnőbb változás az elemi számolási részteszt dichotóm feladatainak lecserélése egy új feladatelrendezésre („Peti számol” 26. ábra), amellyel a részteszt megbízhatóságát kívántuk javítani. A korábbi feladattípusnál a véletlen találat lehetőségét túl magasnak ítéltük meg, így az új feladattípusnál három válaszlehetőséget adtunk meg. Emellett a korábbi, első részteszt, amely a mennyiségek és számok nevet viselte törlésre került, az első három itemet a részben módosított és kiegészített elemi mủveletvégzés résztesztbe olvasztottuk be, amely részteszt a teszt elejére került. Az időbeli korlátok és a teszt szürővizsgálat (,screening test”) irányba történő módosításai miatt tovább kellett rövidítenünk, emiatt az óvodában megbízhatóan mérő relációk résztesztet is kivettük a második tesztváltozatból. A mennyiségi relációk felismerése már nagycsoportos óvodások jelentős részének is könnyünek bizonyult, így az arra fordított sok item már kevés információt adott a gyermekek fejlődéséről. Az utolsó kettő, az arab szám felismerés és arab számok és mennyiségek résztesztjeink megfelelően müködtek mind az óvodai, mind az iskolai vizsgálatok során, így ezeken csak egy-egy itemet érintő kisebb javításokat végeztünk (2. Melléklet).

Az elemi müveletvégzés részterület tehát kiegészült három itemmel, amelyek az instrukcióban hallott mennyiség kiszámolását mérték 10-es számkörön belül. Ezt követően 20as számkörön belüli mennyiségekkel kellett a gyermekeknek manipulatív számolási feladatokat elvégezni, kiegészíteni, kivonni, részhalmazokra bontani, szorozni a kapott utasítások alapján (24. ábra). A feladatokat egy részét vonszolással (drag and drop), egy másik részét a helyes válaszra kattintva oldhatják meg. Ami mellé beillesztettünk több, 20-as számkörön belüli, összetettebb fejben számolási feladatot is, amiket elsősorban az iskolás korcsoportnak szántunk (25. ábra). 


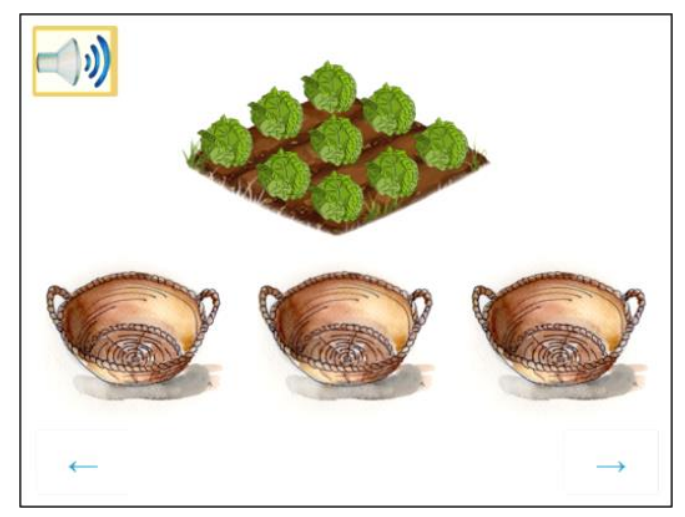

24. ábra

Példafeladat az elemi müveletvégzés résztesztböl. Instrukció: „, Oszd szét a káposztákat! Mindhárom kosárban ugyanannyi legyen!”

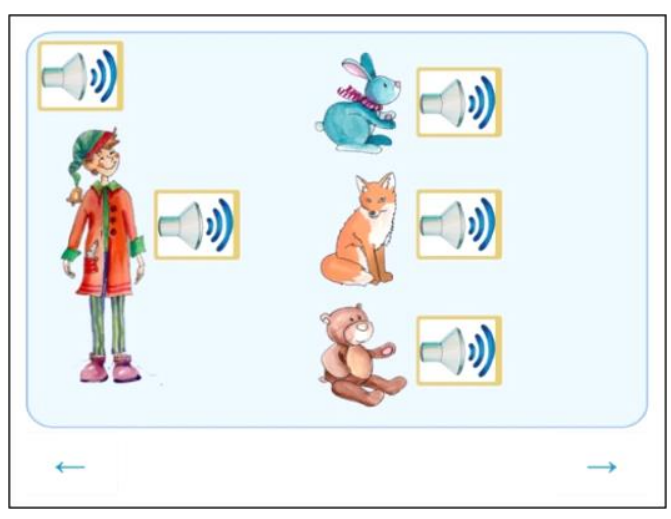

25. ábra

Példafeladat az elemi müveletvégzés résztesztböl. Instrukció: ,, Segits Petinek eldönteni, hogy melyik állat válaszol helyesen egy kérdésre! Ha egy állat melletti hangszóróra kattintasz, akkor meghallasz egy lehetséges választ a kérdésre.

Hallgasd végig a válaszokat és kattints rá arra az állatra, aki helyesen válaszolt! A kérdés a következö. Nekem egy játékom van, neked két játékod van. Mennyi játékunk van összesen? a) Kettö. b) Három. c) Négy."

$\mathrm{Az}$ elemi számolás átdolgozott résztesztjében lecseréltük a korábbi dichotóm feladatainkat, amelyek során számsorokról kellett eldönteni, hogy helyesek-e. Azúj változatban továbbra is zártvégü feladatokkal mérjük a számok megfelelő sorrendjének ismeretét, az 1-től 21-ig számolás, a számkörök átlépésének és visszafelé számolás készségét, viszont már adott számsorok megfelelő folytatását kell a gyerekeknek megtalálniuk. Az új feladatokban a narrátor elkezdi a számolást, elmond egy számsor, amelyet követően a számsor három lehetséges folytatását három állattól hallják a gyerekek. Ezt követően annak az állatnak a képére kattintanak, amelyek szerintük helyesen folytatta a számolást (26. ábra).

Az arab számok felismerése részterület feladatai az első tesztváltozathoz képest egy kivétellel nem változtak. A tanulóknak négy arab számkártya közül kell kiválasztaniuk azt az egy- vagy többjegyü számot, amit az instrukcióban hallanak, válaszukat a megadott kártyák valamelyikére kattintva adhatják meg. A részteszt ötödik feladatának egyik disztraktorát $(170 \rightarrow 404)$ cseréltük le (27. ábra). 


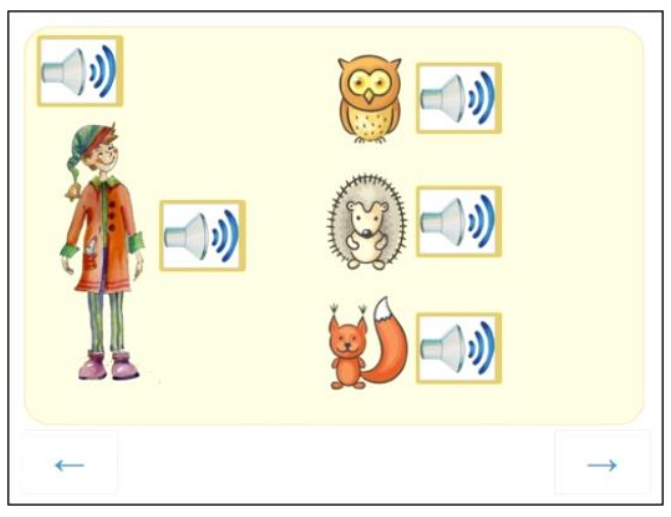

26. ábra

Példafeladat az elemi számolás résztesztböl. Instrukció: „,Segits megtalálni, hogy melyik állat folytatja helyesen a számolást! A számolást mindig Peti kezdi. Ha egy állat melletti hangszóróra kattintasz, akkor meghallod, hogy ö hogyan folytatja a számolást. Kattints rá arra az állatra, aki helyesen folytatta a számolást! Figyelj, Peti most kezdi a számolást! 16, 17, 18 ... a) 19,20,21.d) $19,30,31$. c) $28,38,48$."

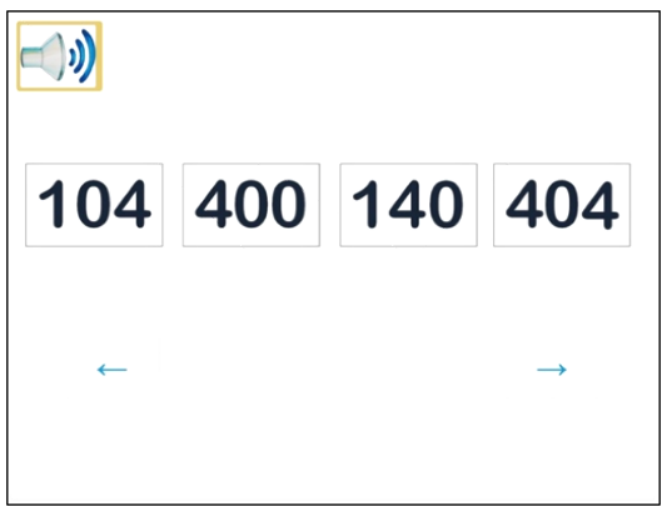

27. ábra

Példafeladat az arab számok felismerése résztesztböl. Instrukció: „,Mondok egy számok. Keresd meg a kártyák között és kattints rá! Tizenkettö."

Mennyiségek és arab számok kapcsolatára vonatkozó részterület feladatai a mennyiségek és arab számok közötti kapcsolatok ismeretét vizsgálja. A feladatok első felében az arab számhoz kapcsolódó mennyiséget vonszolással tudják kirakni egy adott célterületre (28. ábra). A részteszt második felében a képen látott adott mennyiséghez kell párosítaniuk a megfelelő arab számot a kártyákon látható négy lehetőség közül, válaszukat a számkártyára kattintva adhatják meg (29. ábra).

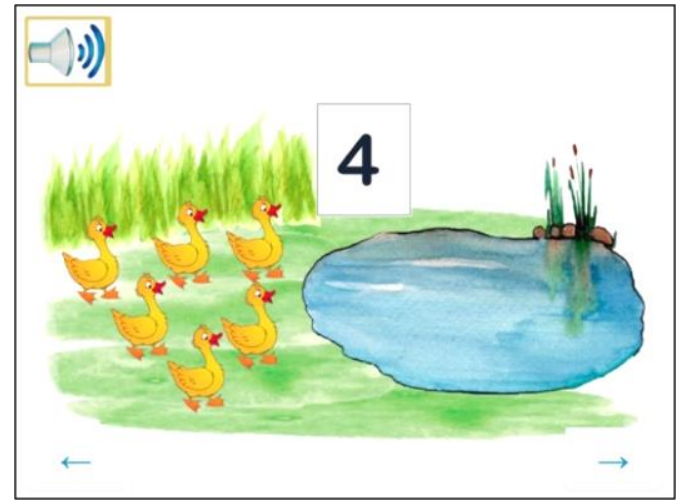

28. ábra

Példafeladat a mennyiségek és számok résztesztböl. Instrukció: „Húzz annyi kacsát a tóra, amennyit a kártyán lévő szám mutat!"

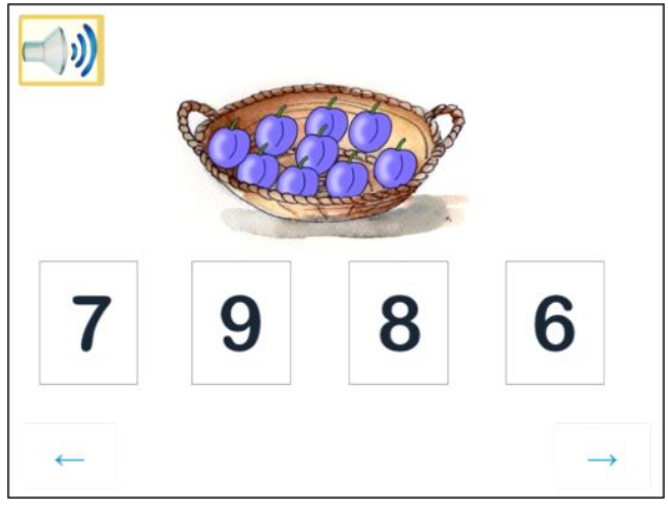

29. ábra

Példafeladat a mennyiségek és számok résztesztböl. Instrukció: „, Kattints arra a számra, ahány szilva van a kosárban!" 


\subsubsection{Vizsgálataink során alkalmazott további mérőeszközök}

DIFER Elemi számolási készség teszt

Validációs céllal vettük fel a második óvodai vizsgálatunkban résztvevő gyermekekkel a DIFER Elemi számolási készség tesztjét (30. ábra). A tesztet részletesen már ismertettük a dolgozat 2. fejezetében, ezért itt a módszereink leírásakor azt csak röviden mutatjuk be, kiegészítve a teszt megbízhatóságának értékeivel.

A teszt az elemi számolási készség négy fö összetevőjét vizsgálja. Az első rész a számolást méri, amelyhez az 1-től 21-ig történő számolás, a számkörök átlépése, visszafelé számolás tartozik. A 21-ig történő számolás összesen 21 pontot ér a tesztben, az ezt követő itemek 1-1 pontot érnek. A teszt második része a manipulatív számolást vizsgálja. A gyermekek összesen 11 különféle, pálcikákkal végezhető műveletet végeznek el a mérőbiztos utasításainak megfelelően. Ez a részteszt a kiszámlálás, hozzászámlálás, elvétel, bontás és csoportosítás müveleteit vizsgálja 20 -as számkörön belül. A harmadik rész a számképfelismerést, a tárgyak számosságának ismeretét méri, melynél a mérőbiztos által mutatott keretekben lévő számképeket kell felismerni és leolvasni. Az utolsó tesztrész során pedig arab számokat kell leolvasniuk, amelyeket páronként pontozunk. Ezek a feladatok a számolvasást mérik, amely kevésbé hangsúlyosan jelenik meg az összeteljesítményben (Nagy et al., 2004b).
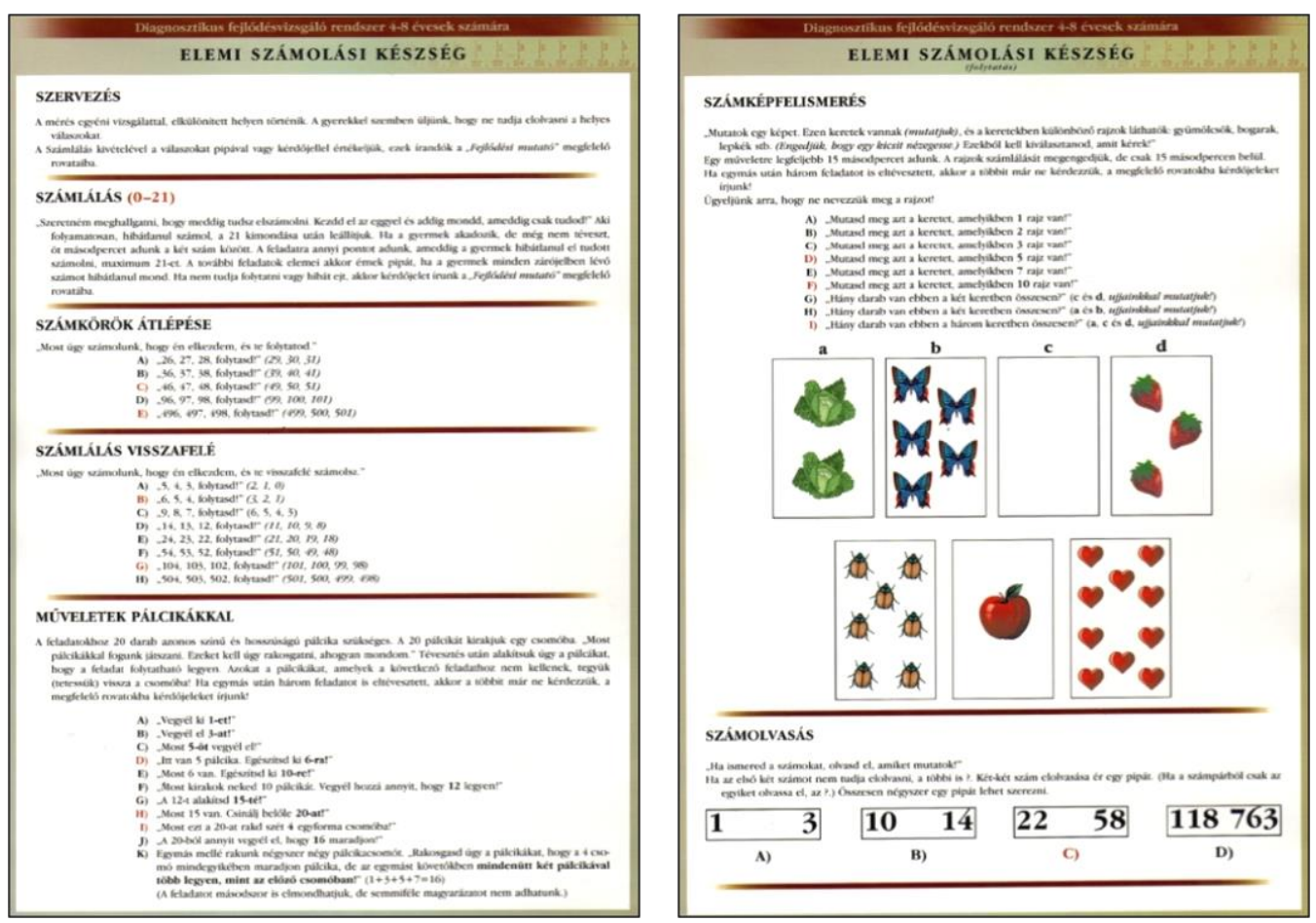

30. ábra

DIFER Elemi számolási készség teszt (Nagy et al., 2004b) 
Elemzéseink elvégzése előtt ellenőriztük a DIFER Elemi számolási készség teszt reliabilitását, amelynek eredményei elfogadhatóak voltak. Az elemzés során nem találtunk kilógó itemet, a 38 itemből álló teszt megbízhatónak bizonyult (Cronbach- $\alpha=0,80)$. A teszt konstruktum validitását nem vizsgáltuk, mivel nem rendelkeztünk a megerösítő faktorelemzést (CFA) elvégzéséhez szükséges a mintaelemszámmal.

\section{DIFER Relációszókincs teszt}

A DIFER Elemi számolási készség tesztjéhez hasonlóan, szintén validálási céllal alkalmaztuk második óvodai mérésünk során a DIFER Relációszókincs tesztjét, amellyel a vizsgálatban szereplők relációszókincsének fejlettségét kívántuk feltárni. A vizsgált elemi alapkészség meghatározó az iskolakezdés, és a későbbi iskolai matematikatanulás szempontjából is. Az általános iskola megkezdéséig a gyermekek jelenős része elsajátítja a nyelv alapját képező relációszavakat, amelyek különféle dolgok közötti viszonyokat fejeznek ki. A DIFER Relációszókincs teszt a magyar nyelvben szereplő legfontosabb relációszavakat tartalmazza. A teszt négy tesztváltozatának mindegyike 24 szóra (20 önálló szó, 4 igekötő) kérdez rá, amelyek reprezentálják a gyermekek relációszókincsét, megmutatják a gyermekek szókincsének elsajátítási szintjét. Az egyes feladatok illusztrálva vannak, és a gyermekeknek a mérőbiztos instrukciói alapján kell arra képre, képrészletre rámutatniuk, amelyik az adott szóra vonatkozik (Nagy et al., 2004b).

Vizsgálatunkban a DIFER Relációsszókincs teszt 1. tesztváltozatát alkalmaztuk (31. ábra). A tesztváltozat 24 itemből áll, amelyek arányosan tartalmazzák a legfontosabb relációszavakat: 8 item térbeli viszonyra vonatkozik (pl. mögött, előtt), 4 item mennyiségekre (pl. számtalan, számos), 4 item igekötős cselekvést (pl. félbevág, levág), 4 item időbeli helyzetet (pl. nyár, tavasz), 4 item pedig hasonlósági viszonyt fejez ki (pl. első, utolsó) (Nagy et al., 2004a).

A teszt megbízhatóságát ellenőrizve a 24 itemes tesztváltozat reliabilitása nem bizonyult megfelelőnek (Cronbach- $\alpha<0,5$ ), ezért kettő időbeli helyzetet mérő, az évszakokhoz illő képekre rákérdező feladat itemeit, amelyek a 30. ábra jobb alsó sarkában láthatóak (R)nyár és S) tavasz) nem vontunk be elemzéseinkbe. A két item elkülönülésmutatója alacsony, negatív értékü $(-0,133$ és $-0,261)$ volt. A 22 itemes teszt reliabilitása elfogadható volt (Cronbach- $\alpha$ =0,62), így eredményeink ismertetésekor az ezek alapján kiszámolt százalékpontos értékeket közöljük, amellyel további elemzéseinket is végeztük. Az alkalmazott eszköz konstruktum- 
validitásáról nem rendelkezünk információval, mivel alacsony mintaelemszám miatt megerősítő faktorelemzést (CFA) nem tudtunk elvégezni.

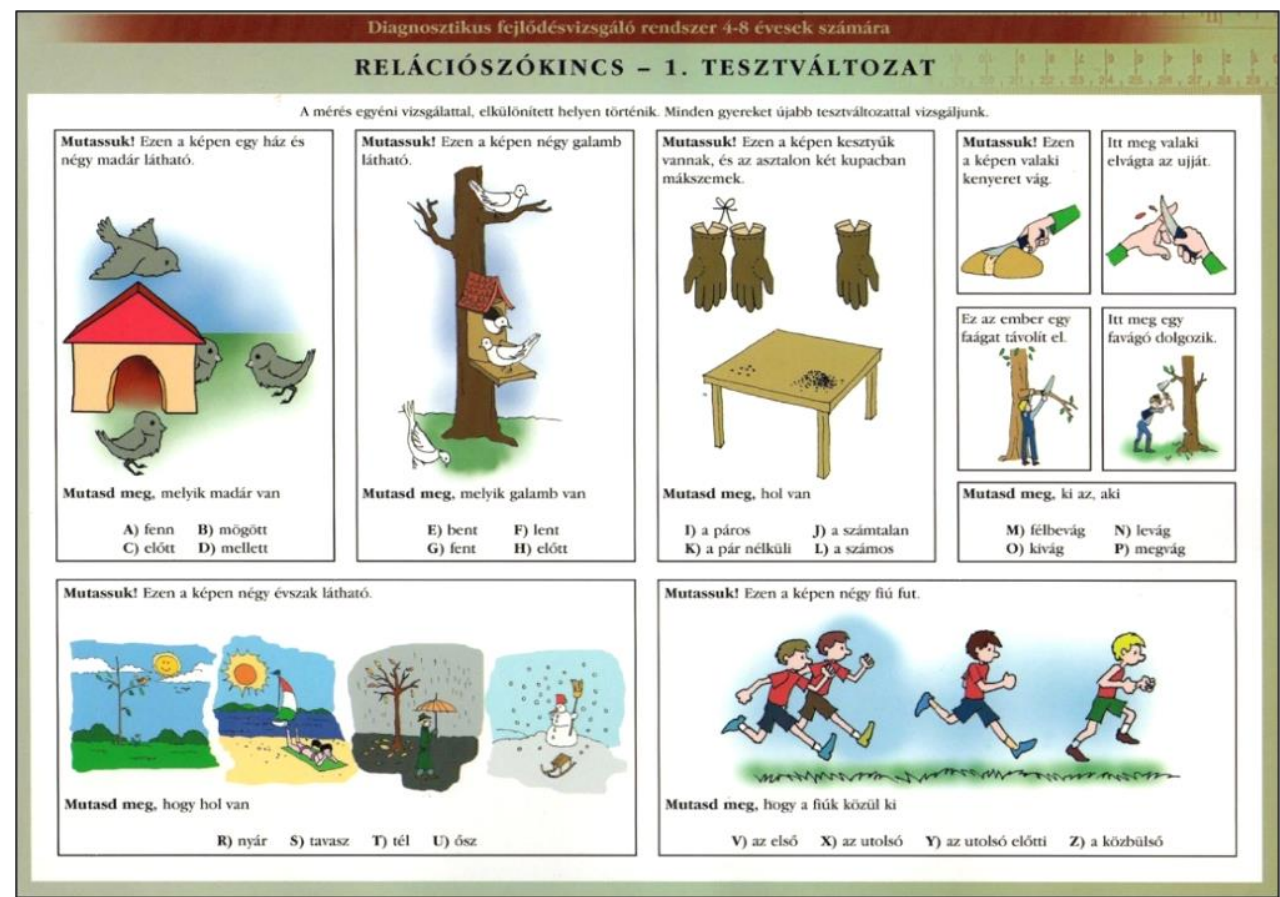

31. ábra

DIFER Relációszókincs 1. Tesztváltozat (Nagy et al., 2004b)

\section{Elsö évfolyam végi matematika tesz,t}

$\mathrm{Az}$ általunk első évfolyam végén alkalmazott matematika teszt a Diagnosztikus Mérések Fejlesztése kutatási projekt során létrejött feladatbank egyik feladatklaszterének felhasználásával készült (Csíkos, Molnár, \& Csapó, 2015).

A teszt feladatai a kutatási projekt első fázisában összeállított tartalmi keretek szerint készültek, azok lefedik a tanulási dimenziókat, és a matematika fö tartalmi területeit (32. ábra). A három fő tanulási dimenziót a gondolkodás, mint pszichológiai dimenzió, az alkalmazás, mint társadalmi dimenzió, a szaktudományi ismeretek, mind diszciplináris dimenzió alkotják. A matematikai tartalmi területek pedig négy fö csoportba sorolhatók, az első a számok, müveletek és algebra területei, a második a relációk és függvények, a harmadik csoport a geometria, és az utolsó halmazban található a kombinatorika, valószínűségszámítás és statisztika (Csíkos \& Csapó, 2011). A tesztben a felsorolt terültek közül az általános iskola első évfolyamának tananyagára alapozva a számok, müveletek és algebra területei voltak 
hangsúlyosabbak, viszont a relációkkal, geometriával és a valószínüségszámítás és statisztika tárgykörébe tartozó itemek is megjelentek (Csíkos, Molnár, \& Csapó, 2015).

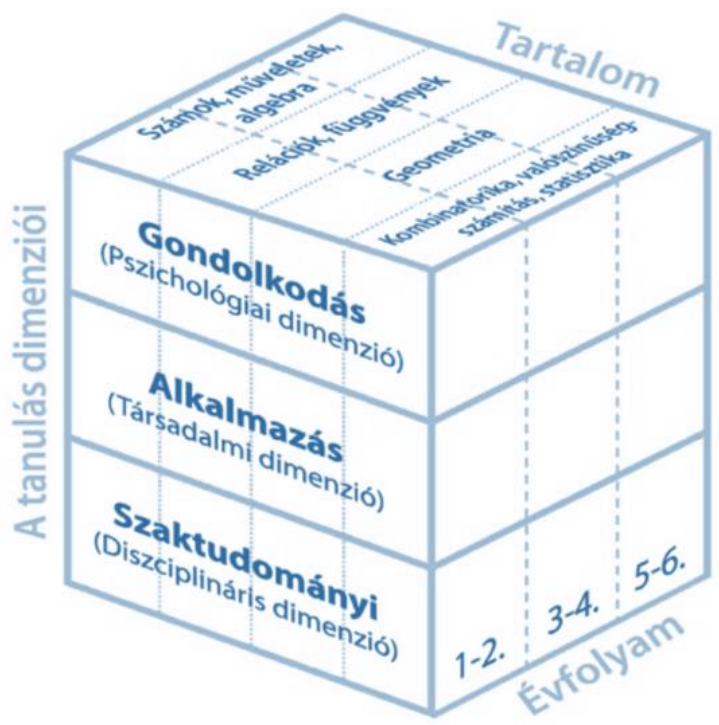

32. ábra

A mérések tartalmának több szempontú elrendezése (Csíkos \& Csapó, 2011, p. 151)

A teszt kialakításakor a feladatbankban szereplö feladatokat azok empirikus jellemzői és a lefedni kívánt matematika tartalmai területek alapján választottuk ki. A feladatokat azonban nem egy az egyben a tesztbankban szereplő formájukban alkalmaztuk. A kiválasztást követően a feladatok fő tartalmi jellemzőit megtartva módosítottunk, az összes feladatnál javítottunk azok kinézetén, a tesztképek elrendezésén, a feladatok szövegezésén, valamint a disztraktorokon is javítottunk, továbbá a tesztbank eredeti feladatklaszterének egyes feladatait töröltük. A méréshez kialakított végleges tesztváltozatban így 13 feladat szerepelt, összesen 50 itemmel (3. Melléklet).
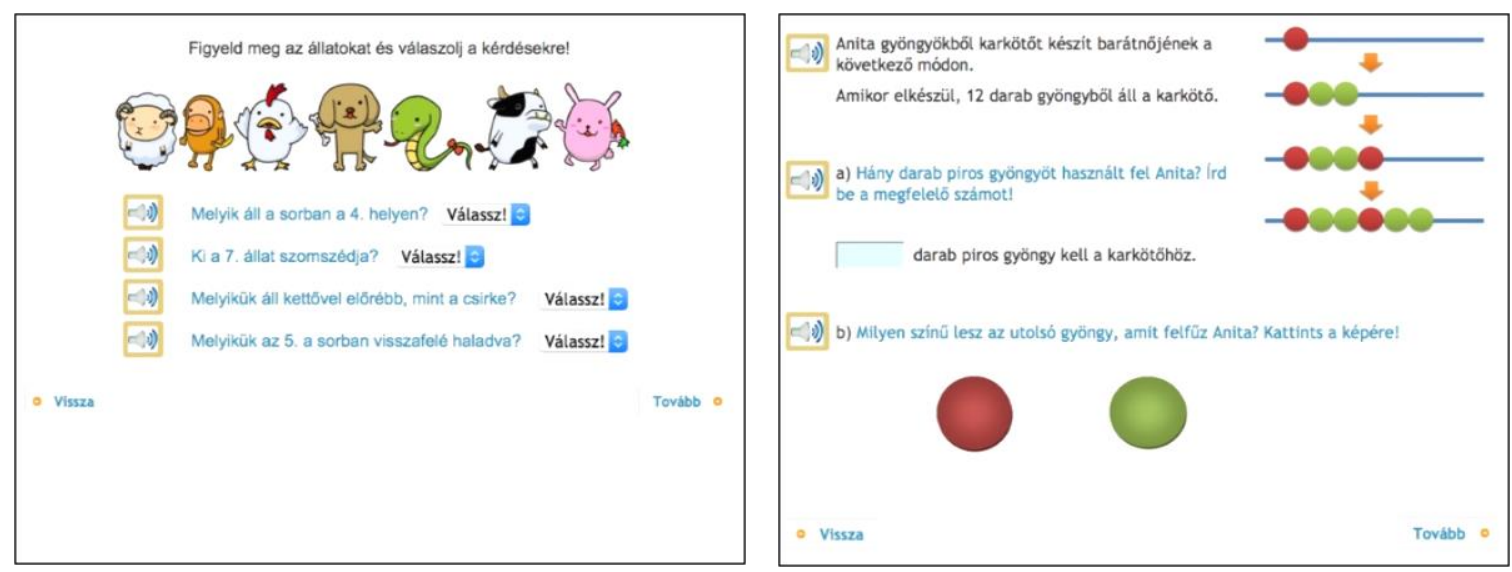

33. ábra

Az elsö évfolyam végi matematika teszt példafeladatai. 
A teszt arányosan tartalmazta a tartalmi keretekben meghatározott három tanulási dimenziót. A gondolkodási dimenzióban 3 feladat (12 item), az alkalmazási dimenzióban 5 feladat (19 item), a szaktudományi dimenzióban pedig szintén 5 feladat (19 item) szerepelt.

A feladatok kialakításakor továbbra is fontos szempont volt az esztétikus, gyermekközeli megjelenés (33. ábra), valamint a teszt instrukcióit, a többi kisgyermekkori méréshez hasonlóan, a tanulók fejhallgatón keresztül is meghallgathatták, emellett azok szövegesen is megjelentek a képernyőn. A válaszadás módja sokrétű volt, a tesztfeladatok megoldásához a kattintás és vonszolás (drag and drop) mellett már kértünk billentyüzeten begépelt számot, továbbá legördülő menüből kiválasztott választ is.

6. táblázat. A matematika a teszt dimenzióinak megbízhatósága

\begin{tabular}{lcc}
\hline \multicolumn{1}{c}{ A matematika teszt dimenziói } & Itemek száma & $\begin{array}{c}\text { Megbízhatóság } \\
(\text { Cronbach- } \alpha)\end{array}$ \\
\hline Gondolkodás & 12 & 0,83 \\
Alkalmazás & 19 & 0,87 \\
Tantárgyi & 19 & 0,88 \\
\hline Teljes matematika teszt & 50 & 0,94 \\
\hline
\end{tabular}

Longitudinális elemzéseink megkezdése előtt ellenőriztük a teszt megbízhatóságát. Reliabilitás-elemzésünk eredményeit a 6. táblázatban összesítettük. A teljes teszt és a hozzá tartozó három dimenzió (gondolkodás, alkalmazás, szaktárgyi) szerinti alskála is megbízható volt, a teljes teszt Cronbach- $\alpha$ értéke kiválónak, a részteszteké jónak tekinthető. Elemzéseink során az elkülönülés-mutatók értékei alapján, egy-két kivételtől eltekintve, nem találtunk kilógó itemeket (8. Melléklet). A részteszteknél végzett reliabilitás-vizsgálat eredményei szerint mindössze két item elkülönítésmutatói voltak 0,3 alatt, és mivel a skálák megbízhatóságának értékét érdemben nem változtatta volna, így egy feladatot sem vettünk ki.

\section{Számitógépes-egér használat és Tablet eszközhasználat}

Az elméleti fejezetek kisgyermekkori online mérés-értékeléssel kapcsolatos részeinél már kifejtett szempontok miatt minden óvodai és iskolai vizsgálatunknak részét képezte egy számítógépes-egér használatot, illetve tablet eszközhasználatot vizsgáló és egyben begyakorló teszt is (Molnár \& Pásztor, 2015a). A mérések lebonyolítása során fontosnak tartottuk, hogy a 
tesztekben is szereplő feladatmegoldási, válaszadási módok begyakorlására is lehetőséget biztosítsunk a mérésben résztvevő gyermekek számára, ezáltal is csökkentve a médiahatás szerepét. Az iskolai Számítógépes-egér használat teszt Molnár Gyöngyvér és Pásztor Attila (2015b) munkája, méréseinkben a szerzők által továbbfejlesztett tesztverziót alkalmaztunk, valamint annak részben módosított óvodai változatát, a Tablet eszközhasználat tesztet Pásztor Attila fejlesztette tovább.

A tesztek segítségével törekedtünk arra, hogy a tanulók teljesítményét ne befolyásolja a mérés során alkalmazott eszközökkel való tapasztalatuk, vagy annak hiánya. Így nem a számolási tesztben találkoztak elöször a válaszadás jellemző módjával. A feladatokat sikertelenség esetén, segítő instrukciók kíséretében, újra megtudták oldani, többszöri sikertelen próbálkozás után viszont tovább engedte őket a rendszer.
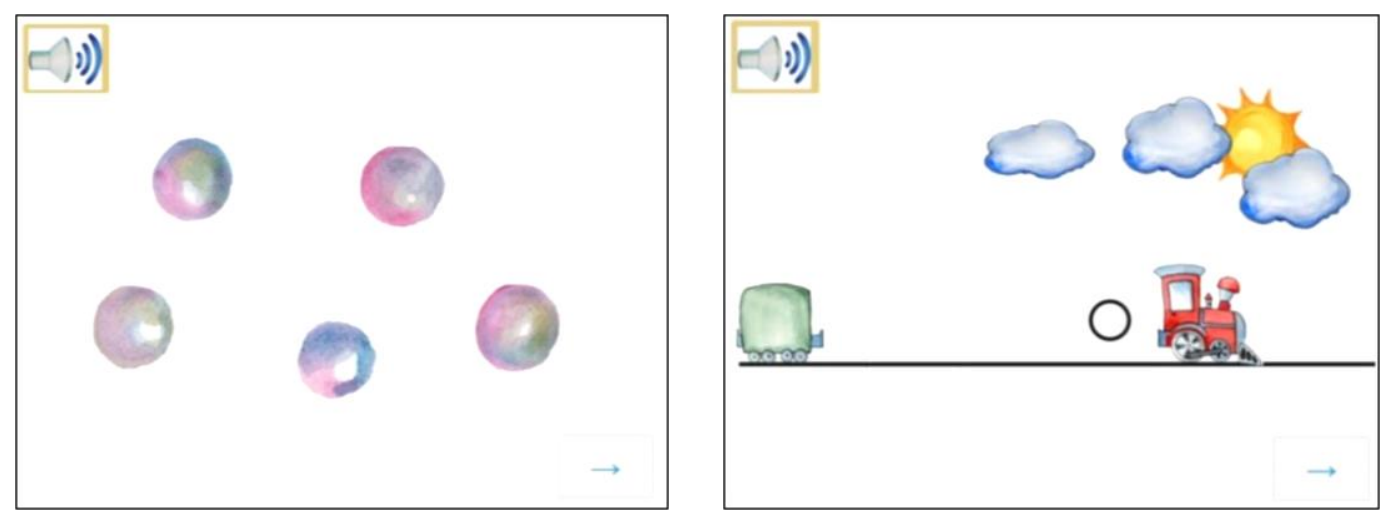

34. ábra

Példafeladatok a Számitógépes-egér használat és Tablet eszközhasználat tesztekböl (Forrás: Molnár \& Pásztor, 2015b; Pásztor, 2016, p. 208-209) [Instrukciók balról jobbra: Pukkaszd ki az összes buborékot! Kattints rájuk!; Csatlakoztasd a vagont a mozdonyhoz! Kattints a vagonra, majd húzd rá a fekete körre!]

Az asztali számítógépre készített iskolai feladatsor elsősorban a kattintás és vonszolás (drag and drop) alapvető egérhasználati műveleteinek mérésére és gyakorlására irányult (34. ábra). Az egérrel végrehajtandó feladatok nehézségét a kattintási célok mérete és száma, továbbá vonszolás esetén a célterület mérete és a mozgatandó elemek száma és mérete határozta meg. A tabletek érintőképernyőire optimalizált óvodai feladatsor esetében pedig pontos érintést (tapping) és vonszolást igénylő feladatokat kellett a gyermekeknek megoldani, az iskolai mérésekhez hasonló nehézségi szintek szerint. 

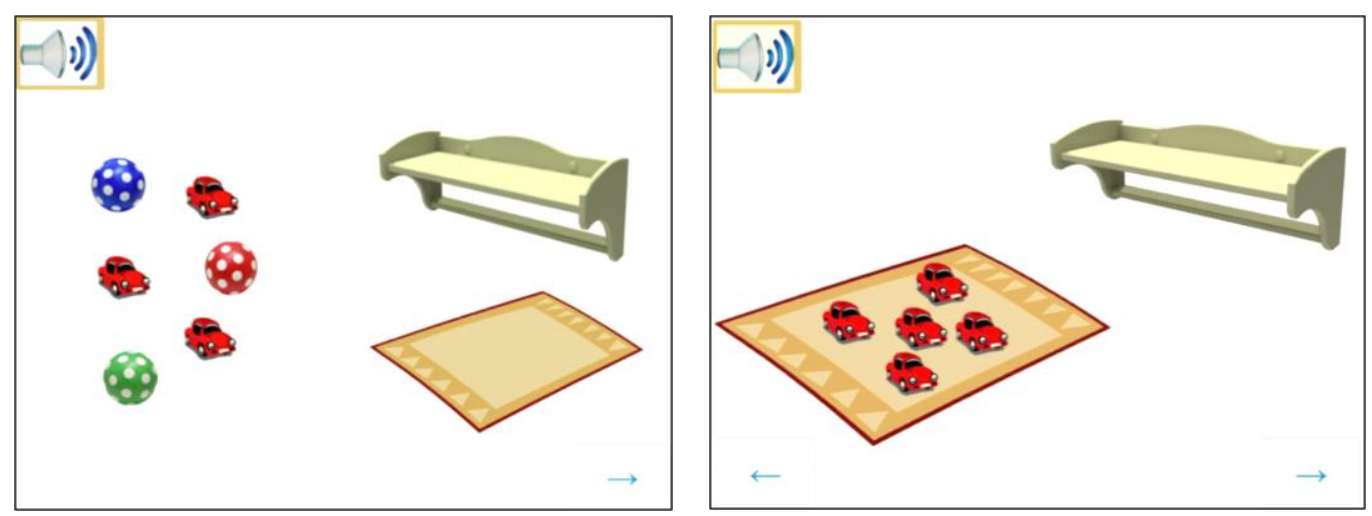

35. ábra

Példafeladatok a Tablet eszközhasználat tesztböl és a Korai numerikus készségek tesztböl (Rausch \& Pásztor, 2017, p. 92 alapján) [Instrukciók balról jobbra: Húzd a matchboxokat a polcra a labdákat pedig a szönyegre!; A szönyegen most öt kisautó van. Húzz annyit a polcra, hogy három maradjon a szönyegen!]

A feladatok úgy lettek kialakítva, hogy az asztali számítógép egerének és a tablet ilyen jellegü használatának begyakorlása mellett a gyermekek megismerkedjenek a későbbi mérések során megjelenő típusfeladatokkal is. Így nem csak az eszközök kezelésében szerezhettek jártasságot, hanem elöre hozzászokhattak a feladatok elrendezéséhez, az instrukciók jellegéhez is. Utóbbi szempont a második, illetve harmadik óvodai és iskolai méréseink során hangsúlyosabban jelent meg, például az 35. ábrán szereplő tablet eszközhasználat tesztből és a korai numerikus készségek tesztből kivágott példafeladatokon is látható a feladatok elrendezése és a feladatmegoldás módja közötti hasonlóság (Rausch \& Pásztor, 2017).

7. táblázat. Számitógépes-egér használat és Tablet eszközhasználat tesztváltozatok itemeinek száma, megbízhatósága és a tanulók átlagos teljesitménye

\begin{tabular}{lccccc}
\hline \multicolumn{1}{c}{ Mérés } & $\begin{array}{c}\text { Itemek } \\
\text { száma }\end{array}$ & $\begin{array}{c}\text { Megbízhatóság } \\
(\text { Cronbach- } \alpha)\end{array}$ & $\begin{array}{c}\text { Minta } \\
\text { elemszáma }\end{array}$ & $\begin{array}{c}\text { Átlag } \\
(\% \mathrm{p})\end{array}$ & $\begin{array}{c}\text { Szórás } \\
(\% \mathrm{p})\end{array}$ \\
\hline Óvoda 1. & 13 & 0,66 & 335 & 90,3 & 12,4 \\
Óvoda 2. & 28 & 0,72 & 251 & 95,1 & 7,5 \\
Óvodai validációs & 16 & 0,40 & 30 & 91,5 & 7,6 \\
Iskola 1. & 13 & 0,65 & 5436 & 91,1 & 13,4 \\
\hline
\end{tabular}

Akárcsak az előzőekben bemutatott többi eszközünknél, Számítógépes-egér használat és Tablet eszközhasználat tesztek megbízhatóságát is ellenőriztük, a tesztek itemeinek számát, az átlageredményeket és a reliabilitás-mutatókat a 6. táblázatban összesítettük. Az második óvodai és az első iskolai mérés esetében rendelkezünk az összes tanuló eredményével, akik egyben a korai numerikus készségek tesztet is kitöltötték. Az első és harmadik óvodai, valamint 
a második iskola mérés esetében voltak tanulók, akik nem értek végig a teljes tablet eszközhasználat, illetve számítógépes-egér teszteken, arányuk a teljes mintához viszonyítva alacsony, az óvodai méréseknél 7 és 1 fö. Továbbá a 2. iskolai mérésnél, amely a 2016 tavaszán a longitudinális mérésünk második pontja volt, már nem volt külön géphasználat feladatsor, a tesztek elején volt egy-egy kattintást és vonszolást gyakorló feladat. A tesztek megbízhatósága alacsony, amely feltehetően részben a magas átlagteljesítmények miatti plafon effektusnak, részben a feladatok végzése során jelentkező tanulási folyamatnak köszönhető. A feladatok megoldása közben folyamatosan gyakoroltak, mivel hibás feladatmegoldás esetén, újra próbálkozhattak, és a soron következő feladatokat már egyre sikeresebben oldották meg a korábban még gyengébben teljesítő tanulók is (Molnár \& Pásztor, 2015b, Rausch \& Pásztor, 2017)

\subsection{Eljárások}

Kisgyermekkori online tesztelés lehetőségeit és kihívásait külön elméleti alfejezetben tekintettük át. Napjainkban a nagymértékü technikai fejlődéssel együtt a technológia alapú mérés-értékelésben rejlő lehetőségeket is egyre jobban ki lehet használni kisgyermekek körében is, azonban fiatalabb életkori csoportok elektronikus mérésénél különösen körültekintően kell eljárnunk. Az általános iskolák eszközparkja megfelelő technológia alapú mérések lebonyolításához, akár az iskola kezdő szakaszában is. Az óvodák esetében viszont árnyaltabb a kép, minden digitális eszközökkel végzett óvodai vizsgálat alapos előkészítést, technikai felkészülést igényel (Molnár és Pásztor-Kovács, 2015; Fáyné Dombi, Hódi \& Kiss, 2016). Vizsgálataink során óvodás és kisiskolás csoportokat teszteltünk, a mérések eljárásait, technikai megvalósítását, és a méréseket követő adatfeldolgozás, adatelemzés jellemzőit ebben az alfejezetben mutatjuk be.

Mint azt már említettük, óvodai vizsgálataink közül az első és a második mérés az SZTE Oktatáselméleti Kutatócsoport és az MTA-SZTE Képességfejlődés Kutatócsoport onlineiskolakezdő mérőcsomag fejlesztéséhez kapcsolóan, a kutatócsoport által szervezett mérések keretei között valósultak meg. A validációs mérés saját szervezésben, a Pallasz Athéné Egyetem Pedagógusképző Kar gyakorló óvodáinak részvételével valósult meg. Iskolai méréseinket az MTA-SZTE Képességkutatócsoport szervezésében végeztük.

A gyermekek minden mérésnél teljesen önállóan oldották meg a feladatokat, a mérőbiztosok kizárólag technikai problémák elhárítása (pl. böngésző ablak véletlen bezárása) 
esetén, továbbá a tesztek elindításában (gyermekek leültetése, mérési azonosítók beírása, hangerő beállítása) segédkeztek. Továbbá online tesztjeink kitöltését minden esetben az eszközök között ismertetett számítógéphasználati, és feladatmegoldási feladatsor (Molnár és Pásztor, 2015) előzte meg, amely során a tanulók találkozhattak és begyakorolhatták a tesztek feladattípusait, válaszadás módjait is. Ezen felül minden teszt elején, a két instrukciós oldalt követően, még szerepeltek bemelegítő feladatok, amelyek a számítógéphasználat teszt feladatihoz hasonlóan müködtek, hibás megoldás esetén újra megkapták azt más, rávezető instrukcióval. A korai numerikus készségtesztnél ezek minden esetben egy vonszolással és egy kattintással megoldható feladatok voltak, amelyek megoldását követően indult el a teszt első, pontot érő feladata. A méréseknél alkalmazott teszek végén pedig a tanulók felé is visszajeleztük az eredményt, az utolsó oldalon, a százalékpontos eredmények mellett, megköszönve a feladatok megoldását, 1-10 db lufi jelent meg, a tanulók teljesítményétől függően.

\section{Az adatfelvétel ütemezése és szervezése}

Az első óvodai vizsgálatunk 2016. március és május között zajlott Szegeden. A méréseket az MTA-SZTE Képességkutatócsoport munkatársai és neveléstudomány mesterszakos hallgatók koordinálták, valamint az SZTE Juhász Gyula Pedagógusképző Kar óvodapedagógia BA szakos hallgatói segítették.

Az óvodai validációs mérést 2016 decemberében bonyolítottuk le Kecskeméten, a Pallasz Athéné Egyetem Pedagógusképző Kar két gyakorló óvodájában. A mérés során az online tesztek felvétele mellett a résztvevő gyermekek szemtől szembeni kikérdezésére is sor került. Az online és a szemtől szembeni mérések során is egyetemi hallgatók segédkeztek a vizsgálatok elvégzésében. Az alkalmazott DIFER résztesztek felvételét másodéves óvodapedagógus hallgatók bevonásával és kiképzésével tudtunk biztosítani. A DIFER Elemi számolási készség és Relációszókincs résztesztjeivel a hallgatók először Az óvodai matematikai nevelés módszertana címü kurzus keretében ismerkedtek meg, az adatfelvétel szemeszterében. A mérésben résztvevő hallgatók ezen felül részt vettek egy fél napos képzésen, amely során részletesen tanulmányozták a két részteszt felépítését, a tesztek felvételének menetét. A képzés során, ellenörzött körülmények között többször elgyakorolták a tesztfelvételt, valamint részletes mérési segédletet is kaptak, amelyet követniük kellett az adatfelvétel során.

DIFER tesztrészek felvétele és kiértékelése az eszköz útmutatója, valamint a DIFER Elemi számolási készség és a Relációszókincs 1. tesztváltozat tesztlapján szereplő 
instrukcióknak megfelelően történt (29-30. ábra). A gyermekek eredményeit azonban nem a Fejlődésmutató füzetekbe, hanem külön erre a célra készített tesztlapokra jegyeztük fel (6. Melléklet), amelyeket később elektronikusan rögzítettünk. Az óvodai vizsgálat során a DIFER tesztek mellett, az online tesztek felvételekor videómegfigyelést is alkalmaztunk. Mérésben résztvevő csoportokból véletlenszerüen kiválasztottunk három gyermeket, akiknél rögzítettük a figyelmüket befolyásoló tényezőket, és a feladatok megoldását, technikai kivitelezését. A videó feldolgozásakor a gyermekek tekintetét figyeltük, valamint a válaszadásnál látható nehézségeket gyüjtöttük ki.

A második óvodai mérésünk 2017. márciustól május végéig tartott, a vizsgálat ismét csak online adatfelvételt tartalmazott, és szervezése a második óvodai mérés jellemzőivel megegyezően zajlott, szegedi óvodákban, kutatócsoporti szervezésben és egyetemi hallgatók közremüködésével.

Az iskolai bemeneti mérésre, amely longitudinális vizsgáltunk első állomása volt, 2015. október közepe és december eleje között került sor. A longitudinális mérés második szakaszára, amely során a tanulók első évfolyam végi matematika teljesítményét vizsgálatuk 2016 május és június eleje között került sor.

\section{Az online mérések technikai megvalósítása}

Az óvodai mérésekre az óvodák egy csoportszobájában, vagy külön fejlesztőtermében került sor. A tableteket asztalon helyeztük el, amelyhez a gyermekeket egyesével, egymástól megfelelő távolságra ültettük le, ügyelve az érintőképernyő kezelhetőségére. A terem méretétől és az elérhető sávszélességtől függően egyszerre 3-6 gyermek tesztelésére volt lehetőségünk. A gyermekeket mindig asztalhoz ültettük, a termek adottságait kihasználva lehetőleg úgy, hogy ne zavarhassák egymást. Méréskor a teremben a mérőbiztosokon és a mérésben résztvevő gyermekeken kívül más nem tartózkodott, a tesztek kitöltése így csendben, zavartalanul folyhatott.

Az óvodai online vizsgálataink technikai lebonyolításához csoportonként 5-6 tabletet és fejhallgatót, egy vagy két mobilinternet elosztót helyeztünk el a mérésre kijelölt helyiségben (36. ábra). A mérésekhez 10" képernyőméretü ASUS K01B típusú, Android operációs rendszert futtató tableteket használtunk. Az instrukciókat a résztvevők a tabletekhez csatlakoztatott gyermek méretü fejhallgatón keresztül hallották, melynek hangerejét a méröbiztosok minden egyes adatfelvétel előtt, illetve közben is ellenőrizték. Továbbá a tesztek egyik első instrukciós oldalán is kértük a résztvevőket ennek ellenőrzésére. 
A tableteken a mérések adminisztrálásához Google Chrome és Mozilla Firefox böngésző applikációt használtunk. Az első két alkalommal egységesen Google Chrome böngészőt használtuk, mivel a tesztek legenerálást követően többször is ellenőrizve az bizonyult a legmegbízhatóbb programnak az eDia rendszeren keresztül futtatott tesztekhez. A feladatok megjelenése egységes, a feladatképek betöltése gyors volt. A harmadik méréshez áttértünk a Mozilla Firefox böngésző applikációra, mivel a Chrome éppen aktuális verziójában a feladatinstrukciók hangfáljai nem indultak el az előzetes beállításoknak megfelelően automatikusan a feladat megnyitásakor azonnal, vagy a beállított időzítés szerint. A Mozilla Firefox böngészővel minden az eredeti beállításainknak megfelelően futott. Mivel a mérésben résztvevő óvodákban nem állt rendelkezésre szélessávú vezetéknélküli internetkapcsolat (wifi), a tabletek internetelérését mobilinternet megosztásával biztosítottuk.

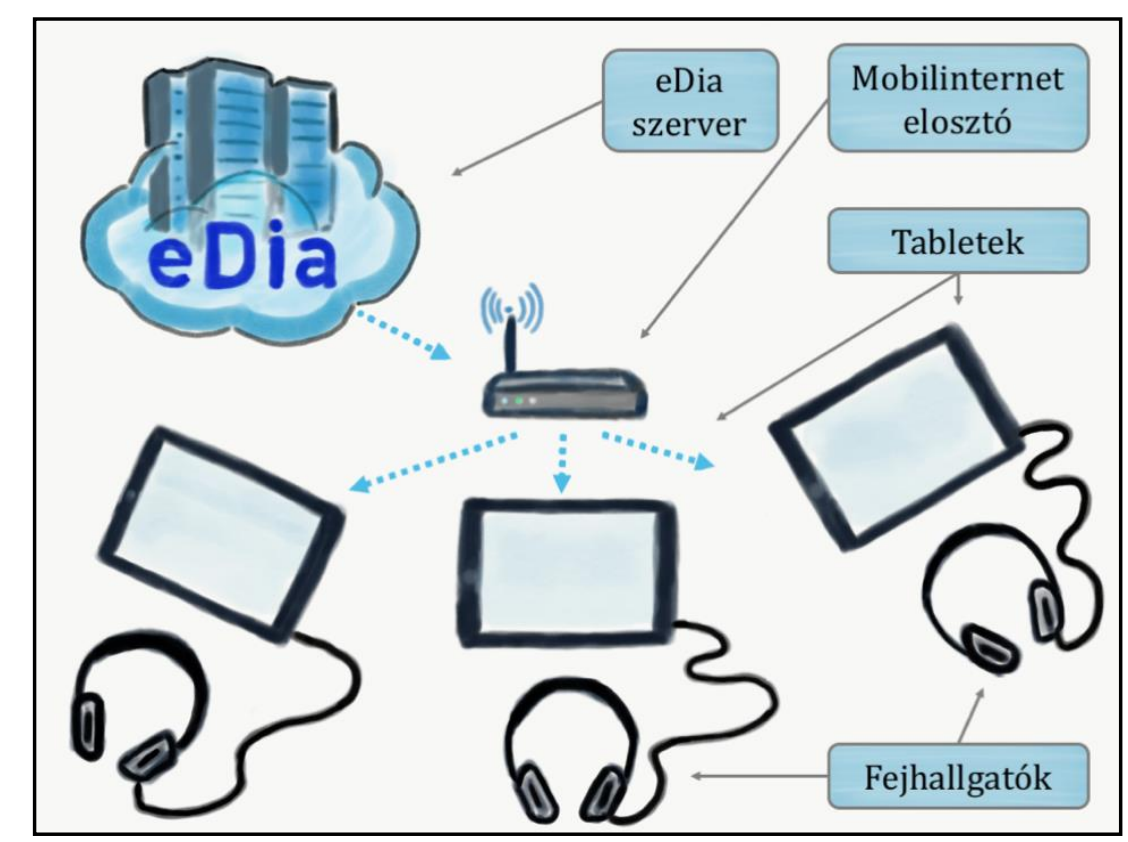

36. ábra

Az óvodai mérések eszközei és technikai megvalósitása (saját ábra).

Az iskolai méréseket a résztvevő iskolák számítógépes szaktantermeiben bonyolítottuk le, és azokat az iskolák pedagógusai felügyelték, akik számára, az adatfelvétel megfelelő körülményeinek biztosításához, részletes mérési útmutatót készítettünk (5. Melléklet).

Az iskolai számítógépes termekben a terem elrendezésétől, az iskola mérésszervezési lehetőségeitől függően 10-20 fő egyidejü adatfelvételére volt lehetőség. A résztvevő intézmények nem először vettek részt eDia platformmal végzett online mérésben, így a technikai szükségletek biztosítására fel voltak előzetesen készülve, amelyet a mérési útmutató instrukciói megerősítettek, esetenként pontosítottak. Az iskolai vizsgálatoknál a szükséges 
eszközök között szerepelt a megfelelő felbontású monitor (minimum 1024x768 képpont), egér, billentyüzet, fejhallgató és stabil internetkapcsolat (37. ábra). Amennyiben az iskola internetkapcsolatának sebességét, megbízhatóságát az iskola rendszergazdája nem ítélte elégségesnek, lehetőség volt a tesztek proxy szerveren keresztüli futtatására is. Proxy szerverrel támogatott adatfelvételkor a tesztek fájljai (pl. képek, hangok) egy iskolai számítógépre elöre letöltődnek, amelyröl a többi számítógép már a belső hálózaton keresztül éri el azokat. Így kiküszöbölve az internetelérés minőségéből fakadó problémákat. Az asztali gépeken a tesztfelvételhez Google Chrome vagy Mozilla Firefox böngészők mindig aktuálisan legfrissebb verziójának használatát kértük, mivel az eDia-rendszert ezekre a böngészőkre optimalizálták (Molnár, Papp, Makay, \& Ancsin, 2015). Asztali számítógépeken mindkét böngészővel megfelelően elindultak az automatikus és időzített instrukciók, a tesztképek és szövegek (az első évfolyam végi mérésnél) hibátlanul jelentek meg.

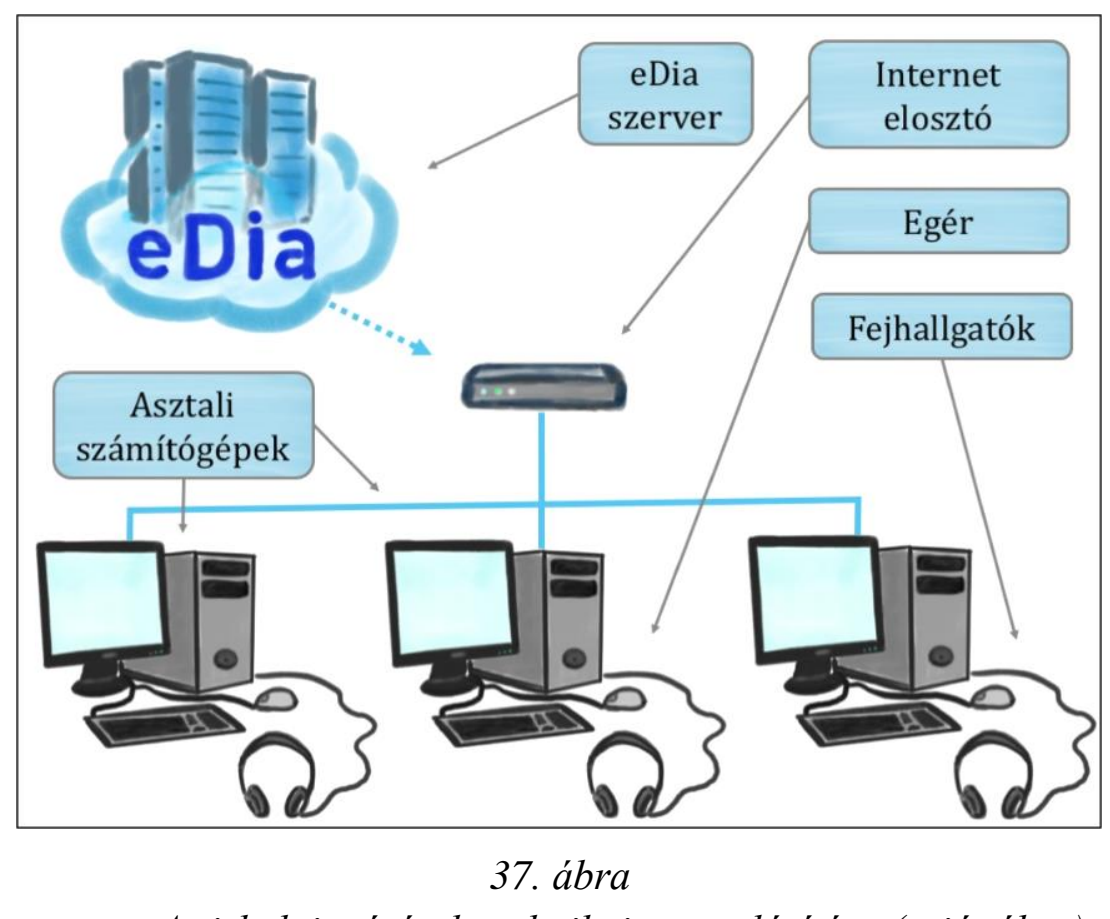

Az iskolai mérések technikai megvalósitása (saját ábra)

\section{Adatrögzítés}

Az online vizsgálatoknál, a mérések lezárását követően az eDia elektronikus mérés-értékelési rendszerből (Molnár, 2015) töltöttük le adatbázisainkat csv, illetve xls formátumban. A mérések teljes adatbázisai számos információt, metaadatot tartalmaznak, amelyek egy részét nem kívántuk bevonni a későbbi elemzésekbe, valamint belefoglalni azok adatbázisaiba. Adatbázisunkat a MS Excel programban rendeztük és tisztítottuk. A MS Excel adatbázisokat 
az SPSS programba átemelve címkéztük, továbbá az egyes alskálák százalékpontos eredményeit is itt összesítettük.

A validációs mérés szemtől-szembeni vizsgálati részénél a DIFER Elemi számolási készség teszt és a Relációszókincs teszt felvétele és kiértékelése a DIFER útmutatója, valamint tesztlapokon szereplő instrukcióknak megfelelően történt. A gyermekek eredményeit azonban nem a Fejlődésmutató füzetekbe, hanem egy adatfelvevő lapra rögzítettük (6. Melléklet), amelyet később MS Excel programban kódoltunk, majd töltöttük át az SPSS statisztikai adatelemző programba, ahol a gyermekek elért teljesítményét százalékpontban összesítettük. Az MS Excel fájlban az adatbázisban a gyermek nevét és azonosítóját is szerepeltettük, mivel ezt használtuk fel eredményeink visszajelentéséhez a mérésben résztvevő óvodai csoportok óvodapedagógusai felé. Az SPSS adatbázisban az eredményeket már név nélkül, kizárólag azonosítók alapján mentettük el. Az Excel fájt pedig a visszajelentést követően megsemmisítettük.

\section{Adatelemzések}

Statisztikai elemzéseink nagy része a klasszikus tesztelmélet eljárásaihoz kapcsolódik. Az SPSS programon belül számítottuk ki a leíró statisztikák eredményeit (átlag, szórás, standard hiba értékei). A tesztek, résztesztek átlageredményeinek további vizsgálataihoz eloszlásvizsgálatokat, különbözőségvizsgálatokat és összefüggésvizsgálatokat végeztünk. A teszteredmények eloszlását egymintás Kolmogorov-Smirnov próbával ellenőriztük. A nemek közötti különbségek összehasonlításához F-próbát követően két mintás t-próbát, illetve dpróbát végeztünk. Az óvodai és az iskolai méréseknél a fejlödés mértékének megmutatására a csoportok mintaelemszámát és a t/d-próbák eredményeit felhasználva hatásméretet is számítottunk (Cohen-d). Az egyes online teszteredmények, valamint a DIFER résztesztek eredményeivel való összefüggések vizsgálatához Pearson korrelációt alkalmaztunk. A teszt és a tesztfeladatok megbízhatóságának ellenőrzéséhez a társadalomtudományi kutatások során széles körben alkalmazott reliabilitás-mutatót, a Cronbach-alfát, valamint az egyes itemek elkülönülésmutatóit használtuk.

A tesztváltozatok konstruktum-validitásának ellenőrzéséhez megerősítő faktorelemzéseket (CFA - Confirmatory Factor Analysis) végeztünk (Muthén \& Muthén, 2010). Ezzel a módszerrel ellenőrizhetjük, hogy a tesztben szereplő egyes változók milyen súllyal kapcsolódnak az előre meghatározott látens faktorokhoz. Míg feltáró faktoranalízisnél (EFA - Exploratory Factor Analysis) előre csupán a faktorok számát adhatjuk meg, és ezt 
követően az elemzés során a program minden itemet minden látens faktorhoz hozzárendel, az így kapott eredmények közül általában faktorrotációt követően, az alacsony faktorsúlyokat kiszürve kapunk átlátható képet. A megerősítő faktorelemzés esetében a teszt szerkezetének megfelelő elméleti modellt előre felvázoljuk, és az elemzés során azt ellenőrizzük, hogy a mért adataink hogyan illeszkednek ehhez a CFA-modellhez. A CFA-modellek illeszkedésvizsgálatánál, a szakirodalmi ajánlásnak megfelelően (Muthén, 1993), az átlósan súlyozott négyzetes becslést alkalmaztuk (DWLS - Diagonally Weighted Least Squares Estimation), és a faktorsúlyoknál a standardizált értékeket néztük.

A CFA-elemzések elvégzésekor modelljeink illeszkedésének ellenőrzésére több, együttesen alkalmazott mutatót kell értelmeznünk (Muthén \& Muthén, 2010). Ezek közül az első a Khi-négyzet $\left(\chi^{2}\right)$ próba eredménye és annak szignifikanciaszintje, és az ehhez tartozó szabadságfok. Khi-négyzet $\left(\chi^{2}\right)$ próba azt mutatja meg, hogy jelentős-e különbség a mért és a várható kovariancia mátrixok között. A szakirodalmi ajánlások alapján nem szükséges elvetnünk a modellünket amennyiben az empirikus adataink szignifikánsan eltérnek a várható értékektől, ebben az esetben további mutatók állnak a rendelkezésünkre, amelyek segítségével vizsgálható a modell illeszkedése.

A társadalomtudományi kutatásokban gyakran közölt két fontos illeszkedésmutató a CFI (Comparative Fit Index) és a TLI (Tucker-Lewis Index), mindkettő esetében a 0,90 feletti értékek az elfogadhatóak, 0,95 felett pedig már kiválónak mondható az illeszkedés (Hu \& Bentler, 1999). E két mutató általában hasonló étéket vesz fel, így általában csak az egyiket szokás közölni, viszont az elemzéseknél minkettőt érdemes figyelni, mivel jelentős eltérés esetén valamilyen módszertani probléma állhat a háttérben. Egy további fontos, reziduálisalapú mutató az RMSEA (Root-Mean-Square Error of Approximation), a becslés hibájának négyzetes középértéke, a Khi-négyzethez hasonlóan mért és a várt értékek közötti különbség kifejezésére szolgál, így értelemszerüen minél alacsonyabb értéket kapunk, annál jobb az illeszkedésünk. Az RMSEA már 0,08 alatt elfogadható, amely adat mellett publikációkban elvárt az ahhoz tartozó konfidencia-intervallum megadása is (Jackson, Gillaspy, \& PurcStephenson, 2009).

Eredményeink bemutatásakor a társadalomtudományi, elsősorban pszichológiai és neveléstudományi publikációkban leggyakrabban közölt, illetve elvárt illeszkedésmutatókat használjuk, amely a Khi-négyzet $\left(\chi^{2}\right)$, a szabadságfok (df), a szignifikanciaszint (p), a CFI és az RMSEA (Jackson, Gillaspy, \& Purc-Stephenson, 2009). Eredményeink értelmezését e 
mutatók együttes áttekintésével és a korábban ismertetett határértékek figyelembevételével végezzük.

Bár több vizsgálatban is megjelenik (lásd: Asztalos \& Csapó, 2016), hogy a CFAelemzéseket a résztesztek a teszthez való illeszkedésének ellenőrzésére használják, amivel igen magas, 1-hez közeli CFI/TLI illeszkedésmutatókat érnek el, azonban összevont változók esetén, például résztesztek átlageredményeivel számolva, az itemek varianciája kikerül számításból, ami jobb illeszkedést eredményez, azonban így a teszt teljes szerkezetére és az egyes itemekre vonatkozóan információval nem szolgál. A skálák szintjén végzett faktoranalízist fontos, hogy megelőzze az itemek szintjén végzett elemzés. Összevont változok alkalmazása elsősorban Strukturális Egyenletek Modellezése (SEM - Structural Equation Modeling) elemzések esetében indokolt, amikor az elemzésnél a változórendszer összefüggéseit, egymásra irányuló hatásait vizsgáljuk. Longitudinális elemzéseink során így jártunk el, a bemeneti mérésen alkalmazott számolási készségteszt első évfolyam végi matematika teljesítményre gyakorolt hatásának elemzését az átlageredmények folytonos változóin végeztük. A CFA-hoz hasonlóan a SEM-elemzések esetén is egy elméleti modell illeszkedését vizsgáljuk, és ennek kiértékeléséhez ugyanazok, a már bemutatott illeszkedésmutatók állnak rendelkezésünkre. Ezen felül az elemzések során korrelációs- és regressziós-együtthatókat tudunk számítani (Muthén \& Muthén, 2010).

Megerősítő faktorelemzéseink során a tesztitemek dichotóm változóival végeztük az elemzéseinket, amellyel a teszt struktúrájának, és az egyes itemek jellemzőinek részletesebb feltárása volt a célunk, ezáltal a tesztek teljes szerkezetének empirikus ellenőrzésére sor került, amelyhez kapcsolódva elemzéseinket kiegészítettük a különböző CFA-modellek illeszkedéseinek statisztikai összehasonlításához használatos Khi-négyzet különbözőség próbával (Chi-square Difference Test). Így megtudhatjuk, hogy ugyanazon az adatsoron tesztelt több elméleti CFA-modell közül melyik modell (pl. 1, 2 vagy 6 dimenziós modellek) illeszkedése statisztikailag a legjobb (Bryant \& Satorra, 2012).

A klasszikus tesztelmélet statisztikai elemzései mellett a valószínűségi tesztelmélethez (IRT - Item Response Theory) tartozó Rasch-modellt is alkalmaztuk (Molnár, 2006). A Raschmodell pedagógiai kutatásokban jól alkalmazható eljárás, amely az itemek nehézségét és a személyek képességszintjét valószínűségelméleti módszerekkel írja le. A modell segítségével meghatározható az egyes itemek nehézsége és a mérésben résztvevő személyek képességszintje, amelyeket közös skálán (logit) is ki tudjuk fejezni. Mind a személyek, mind az itemek tekintetében le tudjuk írni, hogy egymáshoz képest hol helyezkednek el, egyes személyek mennyivel jobb vagy gyengébb képességűek, egyes itemek mennyivel nehezebbek 
a többinél (Molnár, 2013). Ezáltal elemzéseink során, a teszt fejlesztéséhez fontos információt kapunk.

A Rasch-modell esetében is van lehetőségünk a teszt megbízhatóságának ellenőrzésére az EAP/PV (Expected A-Priori / Plausible Values) mutató által, amit modell által megmagyarázott variancia és a teljes variancia hányadosa ad meg. A mutatót, amely 0 és 1 közötti értéket vehet fel, a klasszikus tesztelméletnél alkalmazott Cronbach- $\alpha$ határértékeihez hasonlóan tudjuk értelmezni (Neumann, Neumann, \& Nehm, 2011), vagyis 0,8 felett jónak, 0,9 vagy annál magasabb érték esetén kiválónak tekinthető. Ezen felül a valószínüségi tesztelméletre épülő Rasch-elemzésnél minden mérésnél ellenőriztük a személy szeparációs reliabilitás indexeket is.

Az IRT-elemzések elvégzéséhez a ConQuest statisztikai programot használtuk, amelyhez az SPSS programból kimásolt, csak az adott teszt feladatainak dichotóm változóit tartalmazó adatbázist hoztunk létre.

\section{Méréseink etikai aspektusai}

Kutatásunk tervezése, végrehajtása, eredményeink elemzése és közlése során mindvégig szem előtt tartottuk a társadalomtudományi kutatások alapvető etikai elvárásait, amely kiterjedt a mérésekben érintettek megfelelő szintű és folyamatos tájékoztatására, az anonimitás biztosítására, az adatok kezelésének és az elemzések elvégzésének alapvető követelményeire (Cohen, Manion, \& Morrison, 2013).

Az óvodai mérések előkészítése során ismertettük az óvodapedagógusokkal és a szülőkkel a mérések célját, menetét és tartalmi kereteit. A szülők minden mérésnél beleegyező nyilatkozattal járultak hozzá gyermekük mérésben való részvételéhez (4. Melléklet). Vizsgálataink során a résztvevők teljes anonimitásának biztosítására törekedtünk. A gyermekek számára mérési azonosítókat generáltunk, a mérési azonosítók és a hozzájuk tartozó nevek listája kizárólag az óvodában álltak rendezésre az adatfelvétel megszervezéséhez és a visszajelentések biztosításához.

Az iskolai méréseket az iskolák pedagógusai felügyelték, akik számára, az adatfelvétel megfelelő körülményeinek biztosításához, részletes mérési útmutatót készítettünk. A tanulók önállóan töltötték ki a tesztet, a mérőbiztosok kizárólag technikai problémák elhárítása (például a böngészőprogram véletlen bezárása) esetén, továbbá a tesztek elindításában (mérési azonosítók beírása, hangerő beállítása) segédkeztek. Az iskolai mérésbe bevont iskolák, a 
vizsgálatokat megelőzően a Köznevelési Információs Rendszerből (KIR) töltötték le a tanulók mérési azonosítóit, amelyet követően név nélkül rögzítették azokat az eDia mérés-értékelési rendszerben.

Az óvodai mérések eredményeit, a teszten és részteszteken elért eredményeket minden esetben visszajelentettük az óvodák, valamint a mérésekben érintett óvodai csoportok óvodapedagógusai felé. A gyermekek eredményeit később az óvodapedagógusok osztották meg a szülőkkel. Visszajelentéskor felhívtuk az érintettek figyelmét arra, hogy mérőeszközünk még fejlesztés alatt átt, ezért semmilyen diagnosztikai célra nem alkalmazható, és nem váltja ki a DIFER vagy más diagnosztikus teszt felvételét.

Az iskolai mérések esetében a mérések eredményeit az iskolák az eDia mérés-értékelési platformra belépve tudták megtekinteni és letölteni. Az iskolák felé nyújtott visszajelentéshez a rendszerből letöltött adatok mellé biztosítottuk a tesztekről készített összefoglaló dokumentumot, leírást, továbbá segédletet a mérések eredményeinek értékeléséhez. 


\section{EREDMÉNYEK}

\subsection{Az első tesztváltozat pszichometriai jellemzői óvodában}

\section{Megbizhatóság}

Eredményeink ismertetését mérőeszközünk első változatának pszichometriai jellemzőivel kezdjük. Ezek között először a teszt megbízhatóságának vizsgálatával kapcsolatos elemzések bemutatásra kerül sor. Az óvodai mérésen a korai numerikus készség teszt és résztesztjeinek megbízhatóságát a 8. táblázatban foglaltuk össze. A teszt reliabilitása magasnak tekinthető (Cronbach- $\alpha=0,94)$, a résztesztek megbízhatósága az alacsonyabb itemszámú résztesztek esetében is elfogadható volt, azok 0,70 és 0,88 Cronbach- $\alpha$ értékek között helyezkednek el, melyek közül a legalacsonyabb értéket az elemi számolás dichotóm feladatokból álló résztesztje érte el. Tesztünk megbízhatóságának és érvényességének ellenőrzése alapján a mérésen szereplő 52 itemből kettőt emeltünk ki, amelyhez az itemek elkülönítésmutatóit és a megerősítő faktorelemzés eredményeit együttesen használtuk fel, így alakultak ki a táblázatban látható mutatók és itemszámok.

8. táblázat. A korai numerikus készségek teszt és résztesztjeinek megbízhatósága az óvodában

\begin{tabular}{lcc}
\hline \multicolumn{1}{c}{ Résztesztek } & Itemek száma & $\begin{array}{c}\text { Megbízhatóság } \\
(\text { Cronbach- } \alpha)\end{array}$ \\
\hline Mennyiségek és számok & 6 & 0,87 \\
Elemi számolás & 8 & 0,70 \\
Relációk & 15 & 0,82 \\
Elemi müveletvégzés & 8 & 0,83 \\
Arab számok felismerése & 5 & 0,82 \\
Arab számok és mennyiségek & 8 & 0,88 \\
\hline Korai numerikus készségek teszt & 50 & 0,94 \\
\hline
\end{tabular}

A reliabilitás-vizsgálat során áttekintettük az itemek teszthez és résztesztekhez mért elkülönítésmutatóit, az egy tizedesjegyre kerekített elkülönítésmutatókat a 38 . ábrán szemléltetjük. Az ábrán is kivehető, hogy az elemi számolás egyik feladata (ED09_BNS) a többi itemtől leszakadva, alacsonyabb $(0,11)$ elkülönítésmutatóval rendelkezett, saját résztesztjén belül is csak 0,14 -es értéket ért el, így a további elemzéseinkből kivettük. Így elértük, hogy az elemi számolás részteszt reliabilitása 0,68-röl 0,70-re emelkedjen. Ezen felül, a később ismertetett megerősítő faktorelemzés (CFA) eredményeire alapozva, az arab számok 
felismerése részteszt egy itemét (VA05) is kiemeltük. Igaz, az item elkülönítésmutatója nem volt kirívóan alacsony $(0,27)$, így a részteszt megbízhatóságán sem változott. A két item kivételét követően a tesztben szereplö többi feladat közül még kettőnél (ED04, RM14) találtunk 0,3 alatti értékeket $(0,27$ és 0,27$)$, kivételük a reliabilitást jelentős mértékben nem javította volna. A reliabilitás vizsgálat teljes táblázatát a 8 . mellékletben helyeztük el, ezen szerepelnek a tesztitemek egész teszthez és a résztesztekhez viszonyított elkülönítésmutatói.

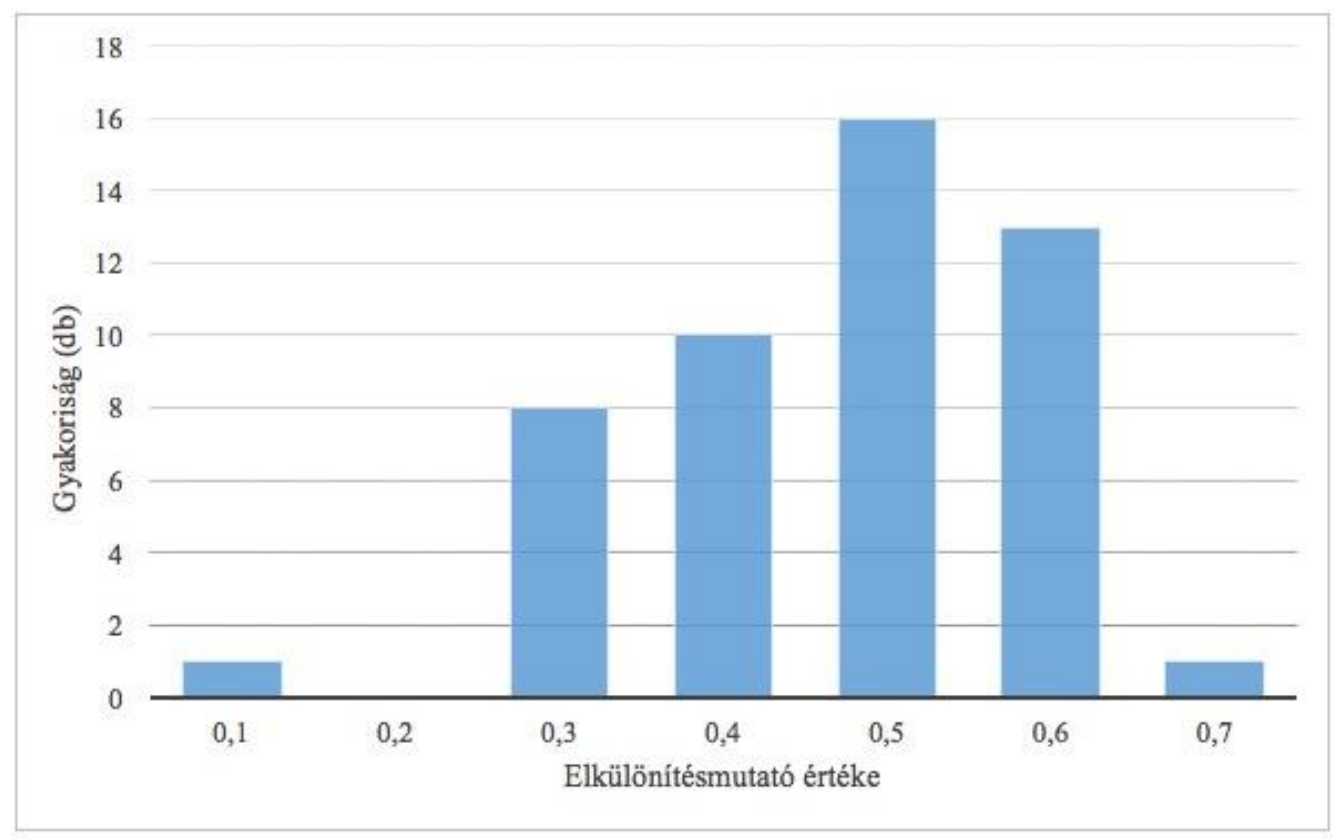

38. ábra

Az itemek elkülönités mutatóinak eloszlási gyakorisága óvodában (1. tesztváltozat)

Nehézségi szintek-Rasch-elemzés

A korai numerikus készségek teszt feladatainak müködését és nehézségi szintjét Raschelemzéssel vizsgáltuk meg. Ez alapján a teszt személy szeparációs reliabilitása 0,99 volt, eszerint a minta vizsgálatához megfelelően müködtek a tesztfeladatok. A teszt EAP/PV reliabilitás értéke 0,92 volt. A Rasch-elemzés személy-item térképét a 39. ábrán mutatjuk be. Ezen a tesztben szereplő sorrendjük szerint számozva szerepelnek a teszt itemei, bal oldalon a felmért óvodás gyermekek képességszintjeit láthatjuk, a bal szélen lévő skála a képesség- és nehézségszinteket mutatja. Az ábrán jól látható, hogy két nehézségi szint területén hiányoznak itemek. Egyfelől voltak olyan gyengébb képességi szinten elhelyezkedő gyermekek, akik számára a tesztfeladatok túl nehéznek bizonyultak, ugyanakkor a magasabb nehézségszinteken is található egy üres folt, vagyis az 1-es és 2-es képességiszint között nincsenek mérőfeladatok a tesztben. 


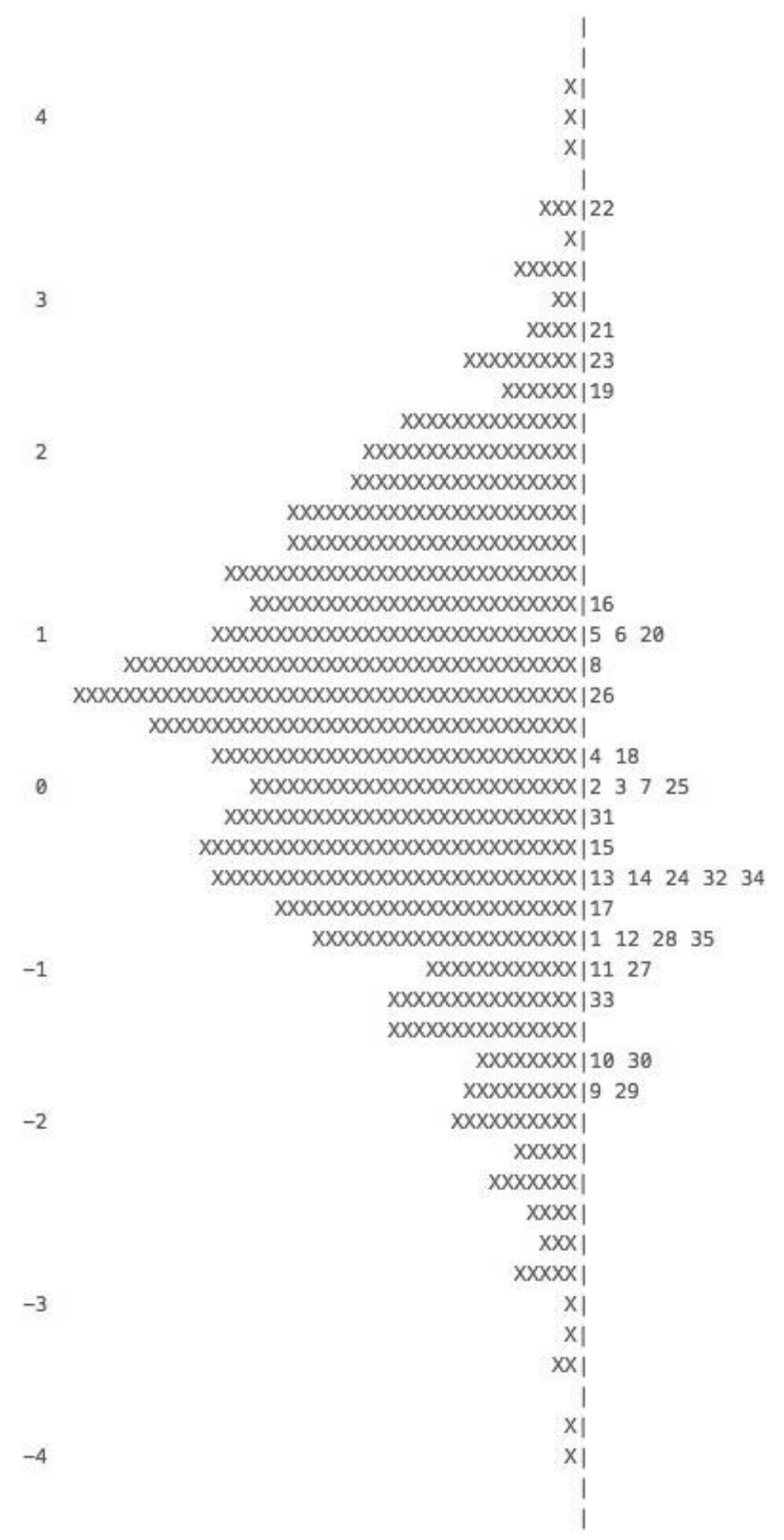

39. ábra

A korai numerikus készségek teszt személy-item térképe az óvodában

Bal oldalon a feladatok nehézsége és a tanulók képességszintje látható. Minden X 0,6 tanulót reprezentál. A jobb oldalon az itemek sorszáma található. 


\section{Konstruktum-validitás}

A korai numerikus készségek teszt struktúrájának ellenőrzéséhez megerősítő faktorelemzést végeztünk, továbbá megvizsgáltuk a teszt és résztesztjeinek összefüggéseit is. A 9. táblázatban összesítettük a résztesztek Pearson korrelációs együtthatóit. A teszt egészével mindegyik részteszt magasan korrelál $(\mathrm{r}=0,70-0,85)$, valamint mindegyik részteszt között szignifikáns összefüggés tapasztalható. Magasabb korrelációt a két arab számokat tartalmazó részteszt, valamint a relációk és az elemi műveletvégzés, valamint a mennyiségek és arab számok résztesztjei között találtunk. Bár az egyes résztesztek itemeinek száma ebben a tesztváltozatban nem teljesen arányosan oszlott meg, mivel azok mindegyike erősen kapcsolódik a teljes teszthez, így feltételezzük, hogy összességében egy közös konstruktumot alkotnak, az elemi számolási készségeket. Ennek ellenőrzésére, és teszt konstruktum-validitásának igazolásához végeztünk megerősítő faktorelemzést (CFA). A faktorelemzés során több modell illeszkedését is megvizsgáltuk, és statisztikailag is összehasonlítottuk.

9. táblázat. Az első tesztváltozat és résztesztjeinek korrelációs együtthatói az óvodában

\begin{tabular}{lcccccc}
\hline \multicolumn{1}{c}{ Résztesztek } & $1 \mathrm{a}$ & $1 \mathrm{~b}$ & $1 \mathrm{c}$ & $1 \mathrm{~d}$ & $1 \mathrm{e}$ & $1 \mathrm{f}$ \\
\hline $1 \mathrm{a}$ - Mennyiségek és számok & - & & & & & \\
1b - Elemi számlálás & 0,42 & - & & & & \\
1c - Relációk & 0,51 & 0,56 & - & & & \\
1 d - Elemi múveletvégzés & 0,60 & 0,52 & 0,67 & - & & \\
1e - Arab számok felismerése & 0,50 & 0,46 & 0,60 & 0,59 & - & \\
1f - Arab számok és mennyiségek & 0,49 & 0,45 & 0,60 & 0,64 & 0,71 & - \\
\hline 1 - Korai numerikus készségek teszt & 0,73 & 0,70 & 0,85 & 0,85 & 0,79 & 0,82 \\
\hline
\end{tabular}

Megjegyzés. A korrelációk p $<0,001$ szinten szignifikánsak.

Megerősítő faktorelemzéseink során több lehetséges CFA-modellt készítettünk, és vizsgáltuk meg illeszkedésüket. Az elemzéseinkbe végül 50 itemet vontunk be a lehetséges 52ből. A reliabilitás-vizsgálat során is azonosított két feladat kiemelése javította a modellek illeszkedését is, így a következő eredmények az eddig is ismertetett 50-böl álló tesztre vonatkoznak.

Az 1-dimenziós modell esetében a tesztben szereplő összes itemet egy közös faktorra helyeztük, amennyiben azt feltételezzük, hogy azok együttesen a korai numerikus készség egyetlen közös faktorát alkotják. A 2-dimenziós modellnél külön faktorba soroltuk az arab számokat megjelenítő, valamint a kizárólag verbális számokkal és mennyiségekkel operáló feladatokat. 
10. táblázat. A korai numerikus készségek elsö tesztváltozat megerősitő faktorelemzésének eredményei az óvodában

\begin{tabular}{rcccccc}
\hline Modell & $\chi^{2}$ & $\mathrm{df}$ & $\mathrm{p}<$ & CFI & TLI & RMSEA (95\% CI) \\
\hline 1-dimenzió & 2868,26 & 1175 & 0,001 & 0,891 & 0,886 & $0,065(0,062-0,068)$ \\
2-dimenzió & 2467,12 & 1174 & 0,001 & 0,917 & 0,913 & $0,057(0,054-0,060)$ \\
6-dimenzió & 1900,82 & 1169 & 0,001 & 0,953 & 0,951 & $0,043(0,039-0,046)$
\end{tabular}

Megjegyzés. $\mathrm{df}=$ degrees of freedom (szabadságfok); $\mathrm{CFI}=$ Comparative Fit Index; TLI = TuckerLewis Index; RMSEA = Root Mean Square Error of Approximation; CI = confidence interval.

Az utolsó, 6-dimenziós modellünket a tesztben szereplö 6 résztesztnek megfelelően alakítottuk ki. Az egyes modellek illeszkedésmutatóit a 10. táblázatban részletesen közöljük. A CFI és TLI illeszkedésmutatókat nézve, a 2 és 6-dimenziós modellek illeszkedései voltak az elfogadható 0,9-es határérték felett, viszont az 1-dimenziós is megközelítette azt $(\mathrm{CFI}=0,89)$, amelyet egyes itemek kivételével a küszöbérték fölé is emelhettünk volna. Azonban a korai numerikus készégek több összetevő által felépített hierarchikus modelljei az összes itemmel meghaladták az elfogadható értéket. A 2-dimenziós modell illeszkedése megfelelö, ennél az RMSEA 0,057-es értéke viszont valamivel magasabb, mint az ideális 0,05-ös küszöbérték. A 6-dimenziós CFA-modell ugyanakkor minden illeszkedésmutató szerint ideálisan írja le a tesztben megjelenő faktorokat, a CFI ás TLI 0,95 feletti mutatói kiválóak, valamint a 0,04-es RMSEA különösen alacsony, aminek konfidencia intervalluma sem nyúlik 0,05 fölé.

\section{1. táblázat. CFA-modellek Khi-négyzet különbözöségi próbáinak eredményei az óvodában}

\begin{tabular}{rccc}
\hline Modell & $\chi^{2}$ & df & $\mathrm{p}<$ \\
\hline 1-dimenzió és 2-dimenzió & 95,37 & 1 & 0,001 \\
1-dimenzió és 6-dimenzió & 297,25 & 6 & 0,001 \\
2-dimenzió és 6-dimenzió & 169,71 & 5 & 0,001 \\
\hline
\end{tabular}

Megjegyzés. $\chi^{2}=$ Khi-négyzet; $\mathrm{df}=$ degrees of freedom (szabadságfok).

Annak érdekében, hogy statisztikailag is alá tudjuk támasztani, mely CFA-modell illeszkedése volt a legjobb, Khi-négyzet különbözőségi próbákat végeztünk. Ezek eredményeit foglaltuk össze a 11. táblázatban. Khi-négyzet különbözőségi teszt eredményei alapján a részteszteknek megfelelően felépített 6-dimenziós modell illeszkedése az 1- és a 2-dimenziós modellnél is szignifikánsan magasabb volt. Összességében tehát kijelenthető, hogy eredményeink szerint a korai numerikus készségek teszt első változatának konstruktumvaliditása az óvodában megfelelő volt. 


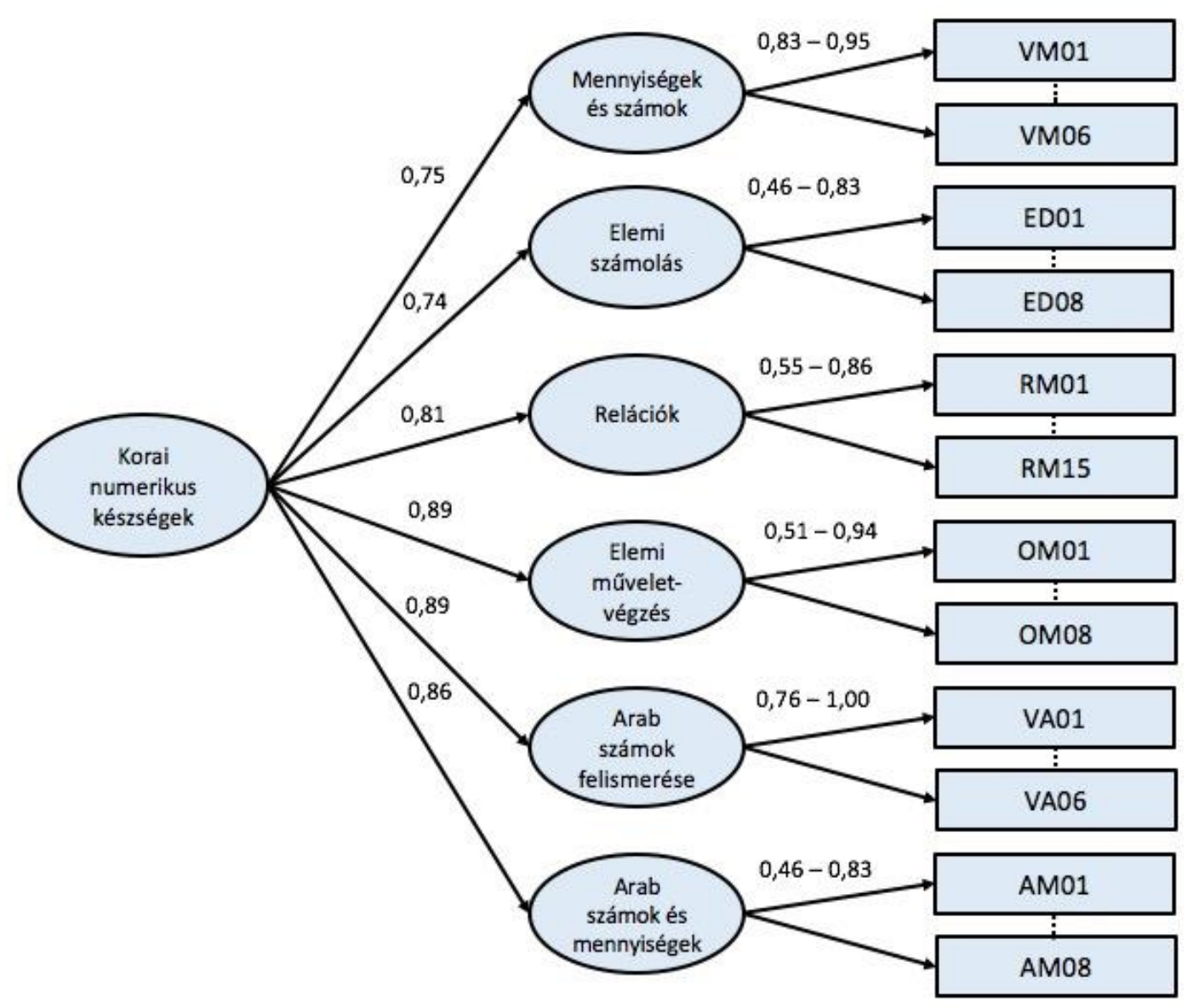

40. ábra

A korai numerikus készségek teszt első tesztváltozatának faktorstruktúrája óvodában

A résztesztek szerint felépített, hierarchikus 6-dimenziós CFA-modell faktorstruktúrája és standardizált együtthatóinak terjedelmei a 40. ábrán láthatóak. Az ábrán téglalappal a tesztben szereplő itemeket, oválissal a CFA-modellben létrehozott faktorokat jelöltük. A nyilak felett szereplő számok a faktorsúlyok standardizált (STDYX) értékei. A tesztben szereplő itemek legtöbb esetben szorosan kapcsolódnak a résztesztjüknek megfelelően létrehozott faktorokhoz, a legalacsonyabb értékek is 0,4 felett helyezkednek el. A legmagasabb együtthatókat a mennyiségek és számok, valamint az arab számok felismerése részteszteknél találjuk, viszont a többi tesztnél kivehető 0,5 körüli alsó értékek előfordulása alacsony. Az elemi számolás dichotóm itemeinél tapasztaltunk jelentősebb szórást a faktorsúlyok esetében, amelyek 0,46-tól 0,83-ig terjednek. A CFA modell következő szintjén a résztesztek alapján létrehozott faktorok a teljes teszt közös faktorához való kapcsolódását vizsgálhatjuk. Az összes részteszt szoros kapcsolatban áll a teljes korai numerikus készségek teszt egészével. Fontos megemlíteni, hogy ez nincs összefüggésben a résztesztek itemszámának arányaival. Az elemi müveletvégzés és az arab számok felismerése kapcsolódik a legnagyobb súllyal $(0,89)$, de a legalacsonyabb elemi számolásnál és a mennyiségek és számok részteszteknél tapasztalt $(0,74-0,75)$ értékek is 
magasak, így a faktorelemzés eredményeire alapozva nem találtunk a korai numerikus készségek tesztből kilógó további itemeket, vagy akár elkülönülő részteszteket.

Átlagteljesitmények és eloszlások

12. táblázat. Az óvodás korú gyermekek korai numerikus készségek teszten és a részteszteken elért eredményei (1. tesztváltozat)

\begin{tabular}{lcc}
\hline \multicolumn{1}{c}{ Résztesztek } & Átlag $(\% \mathrm{p})$ & Szórás $(\% \mathrm{p})$ \\
\hline Mennyiségek és számok & 63,5 & 36,8 \\
Elemi számolás & 49,4 & 26,1 \\
Relációk & 44,9 & 21,5 \\
Elemi múveletvégzés & 66,6 & 30,9 \\
Arab számok felismerése & 60,1 & 36,2 \\
Arab számok és mennyiségek & 70,4 & 33,0 \\
\hline Korai numerikus készségek teszt & 57,2 & 23,3 \\
\hline
\end{tabular}

A teszten elért átlagos teljesítmény az óvodában 57,2 \%p volt, az ehhez kapcsolódó szórás 23,3 \%p. Eredményeink szerint az óvodás gyermekek az arab számok és mennyiségek, valamint a mennyiségek és számok részteszteken értek el jobb teljesítményt, viszont az ezekhez kapcsolódó szórás is magas volt. Szinten magas volt a szórás az arab számok ismeretét vizsgáló feladatok esetében. Továbbá a 15 itemből álló relációk részteszten elért átlagos teljesítmény a várakozásainkhoz képest alacsony lett, akárcsak az elemi számolás résztesztjén elért eredmények.

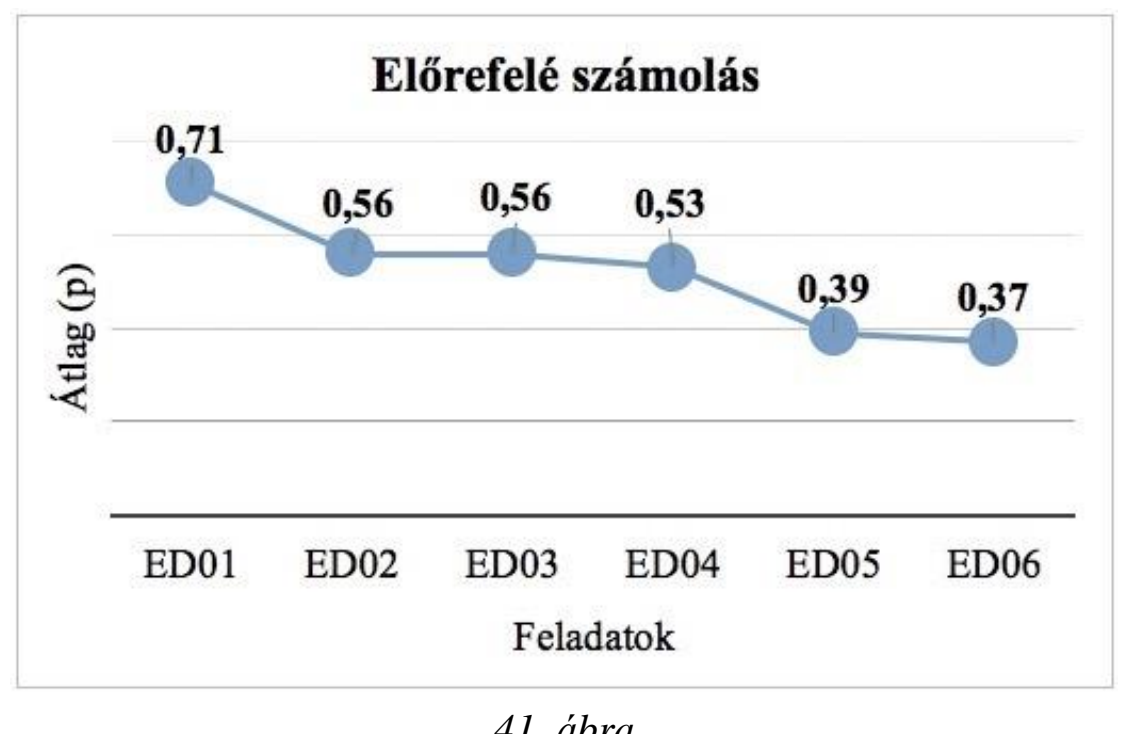

Az elemi számolás részteszt előrefelé számolást mérő feladatain elért átlagpontszám 
Az elemi számolás résztesztben feladatok eldöntendő kérdéseket tartalmaztak. Mivel ezeken a dichotóm feladatokon elért 49,4 \%p-os teljesítmény megegyezhet akár véletlenszerü kattintással elérhető teljesítménnyel, ezért természetesen alaposabban is megvizsgáltuk az egyes feladatokra adott válaszok alakulását. Mint a 41. ábrán látható, az előrefelé számolást mérő feladatokon a gyermekek helyes válaszainak arányai egészen magas szintről indulva fokozatosan csökkentek. A feladatok sorban emelkedő számok helyes sorrendjét, valamint egyre magasabb számkörök átlépésének helyes ismeretét mérték, a gyermekek helyes válaszai így a feladatok várt nehézségéhez igazodtak.

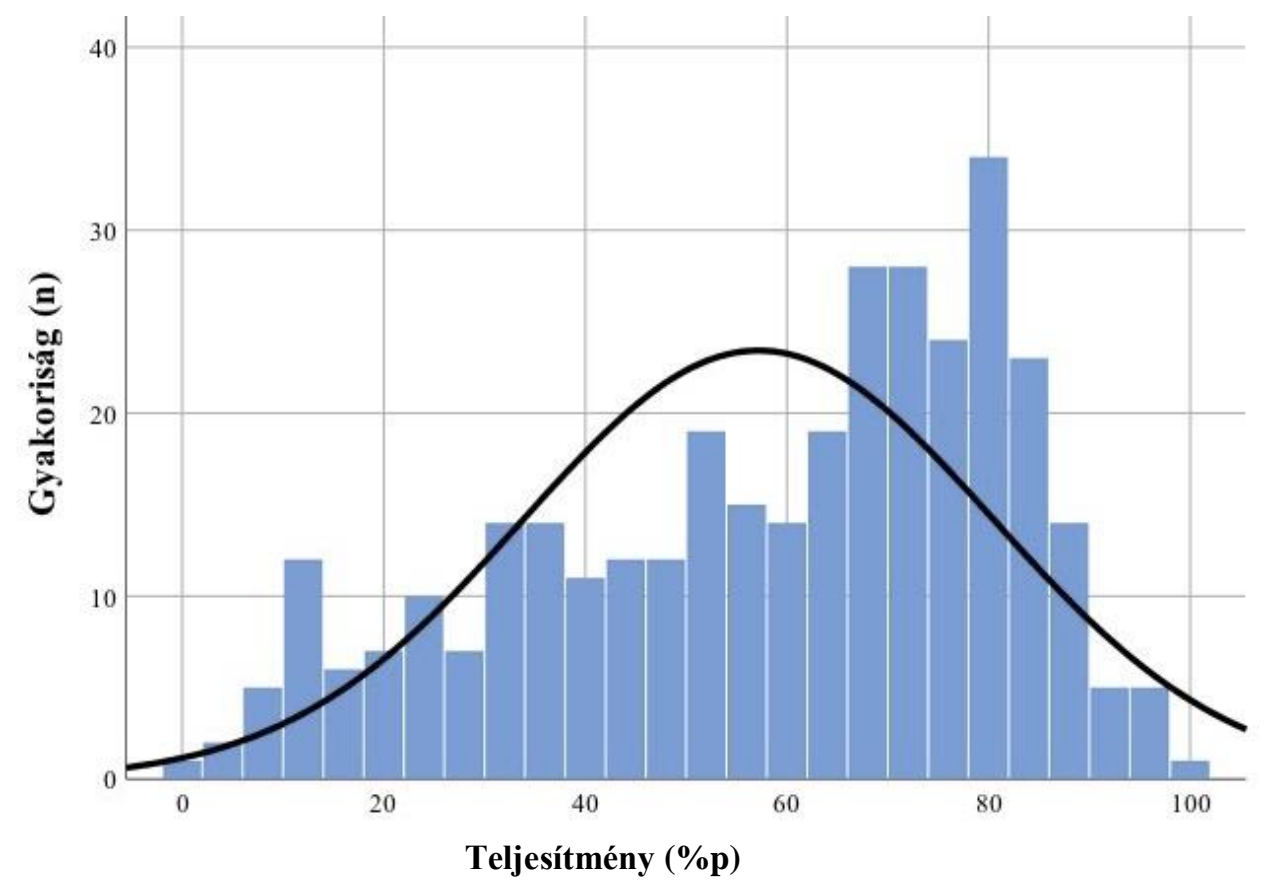

42. ábra

Az óvodás gyermekek átlagteljesitényének eloszlása a korai numerikus készségek teszt első tesztváltozatának résztesztjein

A következőkben a teszten és résztesztjein elért átlagteljesítmények eloszlásaival foglalkozunk. A korai numerikus készségek teszten elért átlageredmények eloszlása az 42. ábrán látható. Az eloszlás jobbra tolódik, valamint ez a jobbra tolódás nem szimmetrikus. A Kolmogorov-Smirnov teszt eredménye alapján szignifikánsan eltér a normál eloszlástól ( $\mathrm{p}<0,01)$. Ábránkon viszonyításképp elhelyeztük a normál eloszlás elméleti görbéjét. Az is kivehető, hogy a 15 és 35 és 55 százalékpontok közelében kisebb emelkedések vannak az átlagok gyakoriságában, ennek a többmóduszú eloszlásnak a részletesebb vizsgálatára mindenképpen célszerủ áttekinteni az egyes a résztesztek eloszlásait. 


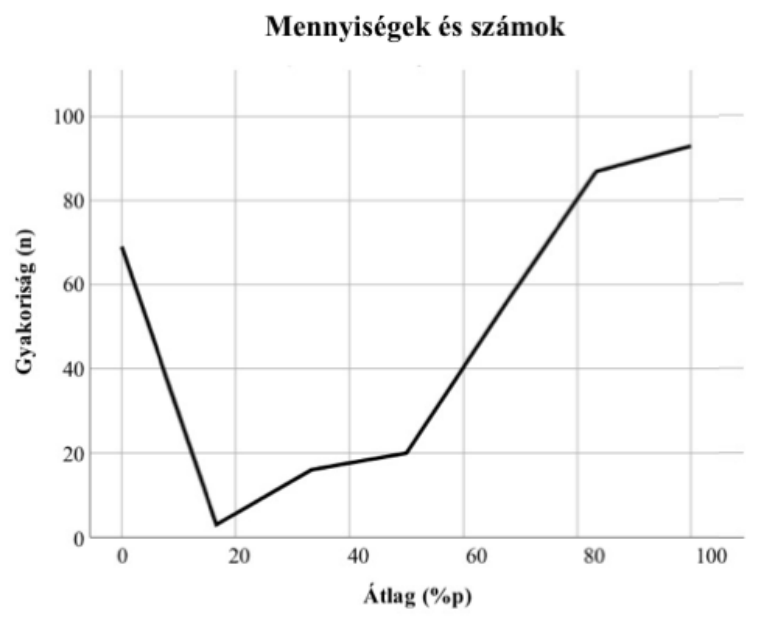

Relációk

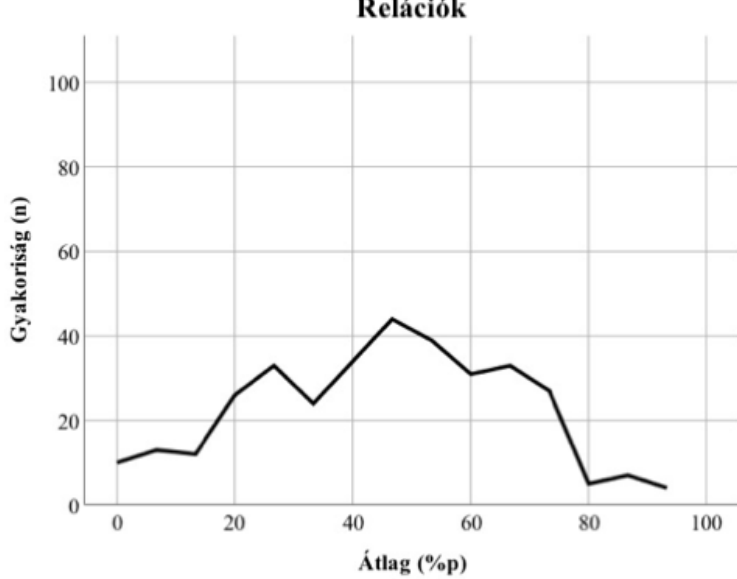

Arab számok felismerése

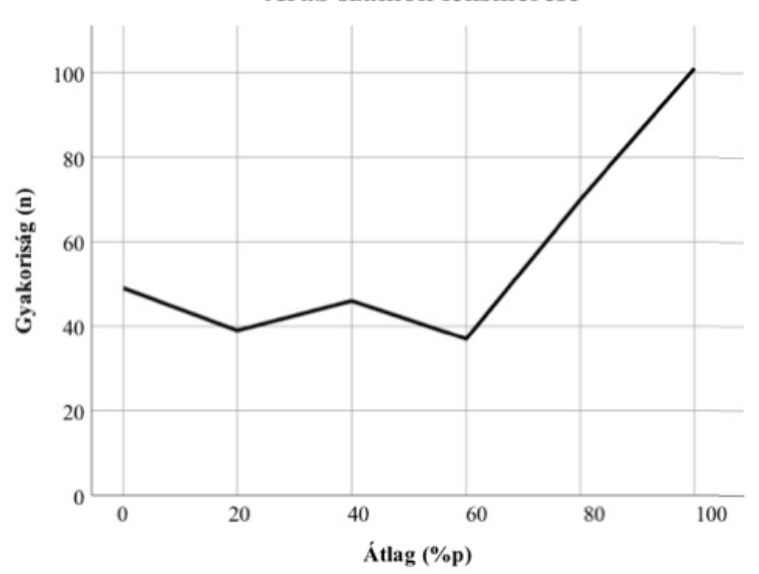

Elemi számlálás

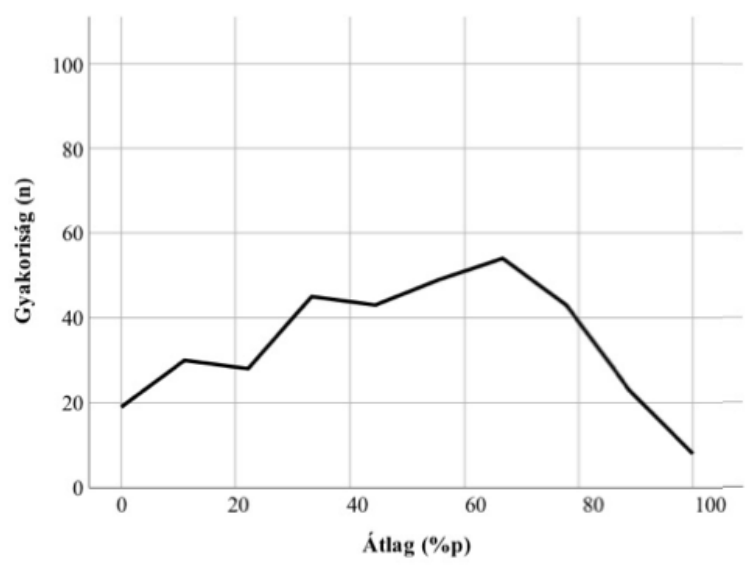

Elemi müveletvégzés

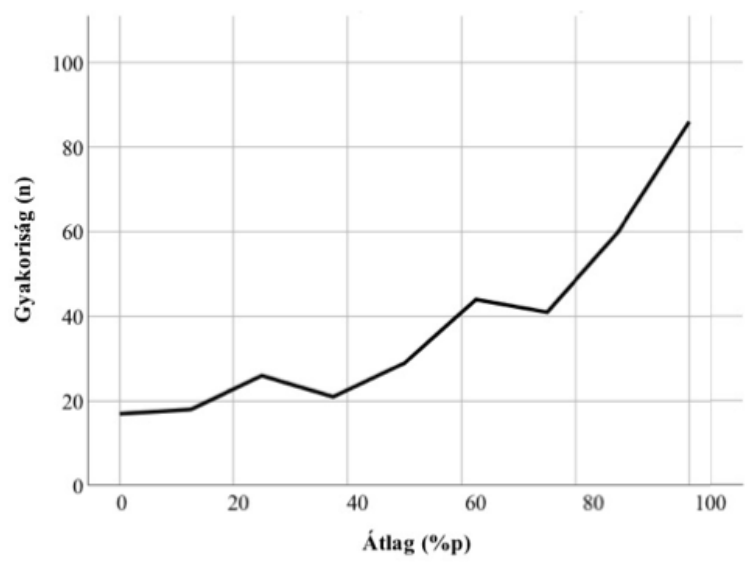

Mennyiségek és arab számok

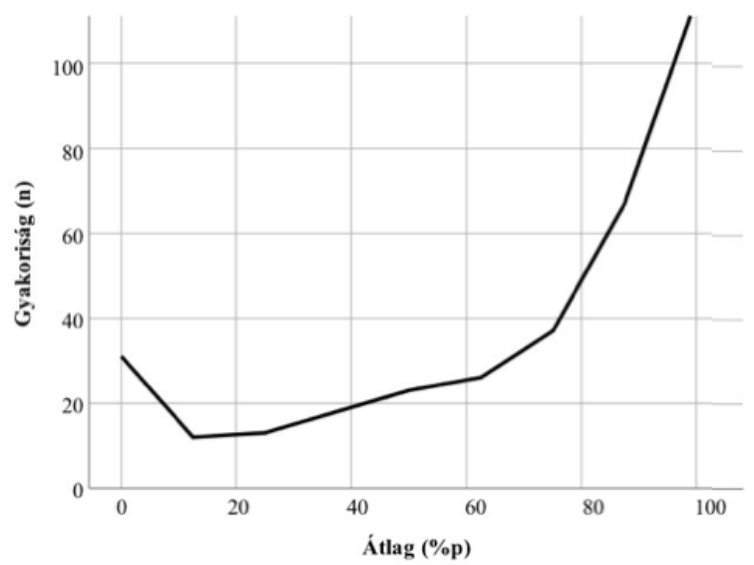

43. ábra

Az óvodás gyermekek átlagteljesitényének eloszlása a korai numerikus készségek teszt résztesztjein (1. tesztváltozat)

A korai numerikus készségek teszt résztesztjeinek eloszlását megvizsgálva azt tapasztaltuk, hogy egyedül az elemi számolás és relációk résztesztek eloszlási görbéi közelítenek a normál eloszláshoz, Kolmogorov-Smirnov teszt értéke is ezeknél a 
legalacsonyabb, de közben ezek lapultsága (Kurtosis) is eléggé alacsony. A másik négy részteszt távol áll a normál eloszlástól, mindegyiknél megfigyelhető jobbra tolódás. Emellett, a mennyiségek és számok, és a két arab számokat tartalmazó résztesztnél is kétmóduszúnak tekinthető az eloszlás, a gyermekek jelentős része leszakadt a többségtől, és az alacsony teljesítményt ért el (43. ábra).

13. táblázat. A teszt és résztesztjeinek eloszlásmutatói óvodás korosztályban (1. tesztváltozat)

\begin{tabular}{lcccc}
\hline \multicolumn{1}{c}{ Résztesztek } & Ferdeség & Lapultság & $\begin{array}{c}\text { Kolmogorov- } \\
\text { Smirnov teszt }\end{array}$ & $\mathrm{p}<$ \\
\hline Mennyiségek és számok & $-0,79$ & $-0,86$ & 0,23 & 0,01 \\
Elemi számolás & $-0,16$ & $-0,87$ & 0,12 & 0,01 \\
Relációk & $-0,11$ & $-0,62$ & 0,09 & 0,01 \\
Elemi müveletvégzés & $-0,67$ & $-0,71$ & 0,18 & 0,01 \\
Arab számok felismerés & $-0,40$ & $-1,27$ & 0,21 & 0,01 \\
Arab számok és mennyiségek & $-0,97$ & $-0,35$ & 0,23 & 0,01 \\
\hline Korai numerikus készségek teszt & $-0,56$ & $-0,68$ & 0,12 & 0,01 \\
\hline
\end{tabular}

Megjegyzés. Ferdeség (szimmetria) = Skewness; Lapultság = Kurtosis; $\mathrm{p}=$ szignifikanciaszint.

\section{Tesztelés ideje és eszközhasználat}

Az óvodai tesztelés időtartama a korai numerikus készségek felmérésénél átlagosan fél óra alatt volt. A mérésben résztvevő gyermekek tesztben eltöltött teljes ideje, amely a mérési azonosító begépelése után egészen a záró képernyőig tart, átlagosan 28,04 perc volt, ugyanakkor nagyon magas szórást (11,18 perc) tapasztaltunk. A tesztfeladatok megoldására fordított idő valamivel kevesebb, 24,86 perc viszont itt is magas volt a szórás (12,09 perc).

Az óvodás gyermekek tablet eszközhasználat teszten elért eredményeit módszereink között ismertettük. A gyermekek átlagos teljesítménye elérte a 90,3 \%p-ot, szórása pedig alacsony volt (12,4 \%p). Ugyanakkor kisebb variancia is elegendő volt ahhoz, hogy a két teszt korreláljon egymással. A mérésben résztvevők korai numerikus készségei és a tablet eszközhasználat teszten elért teljesítménye szignifikánsan összefüggött egymással ( $\mathrm{r}=0,36$; $\mathrm{p}<0,001)$.

A 44. ábrán láthatók a gyermekek eredményei a tablet eszközhasznált teszt és a korai numerikus készségek teszt függvényében. Kivehető, hogy az eszközhasználat teszten elért teljesítmény eloszlása erőteljesen jobbra tolódik, és kevés olyan óvodás gyermek volt, akiknek komolyabb problémát okozhatott a tabletek kezelése, a feladatok érintéssel és vonszolással 
történő megoldása, viszont közülük többen is átlagos, vagy átlag feletti teljesítményt értek el a korai numerikus készségek teszten.

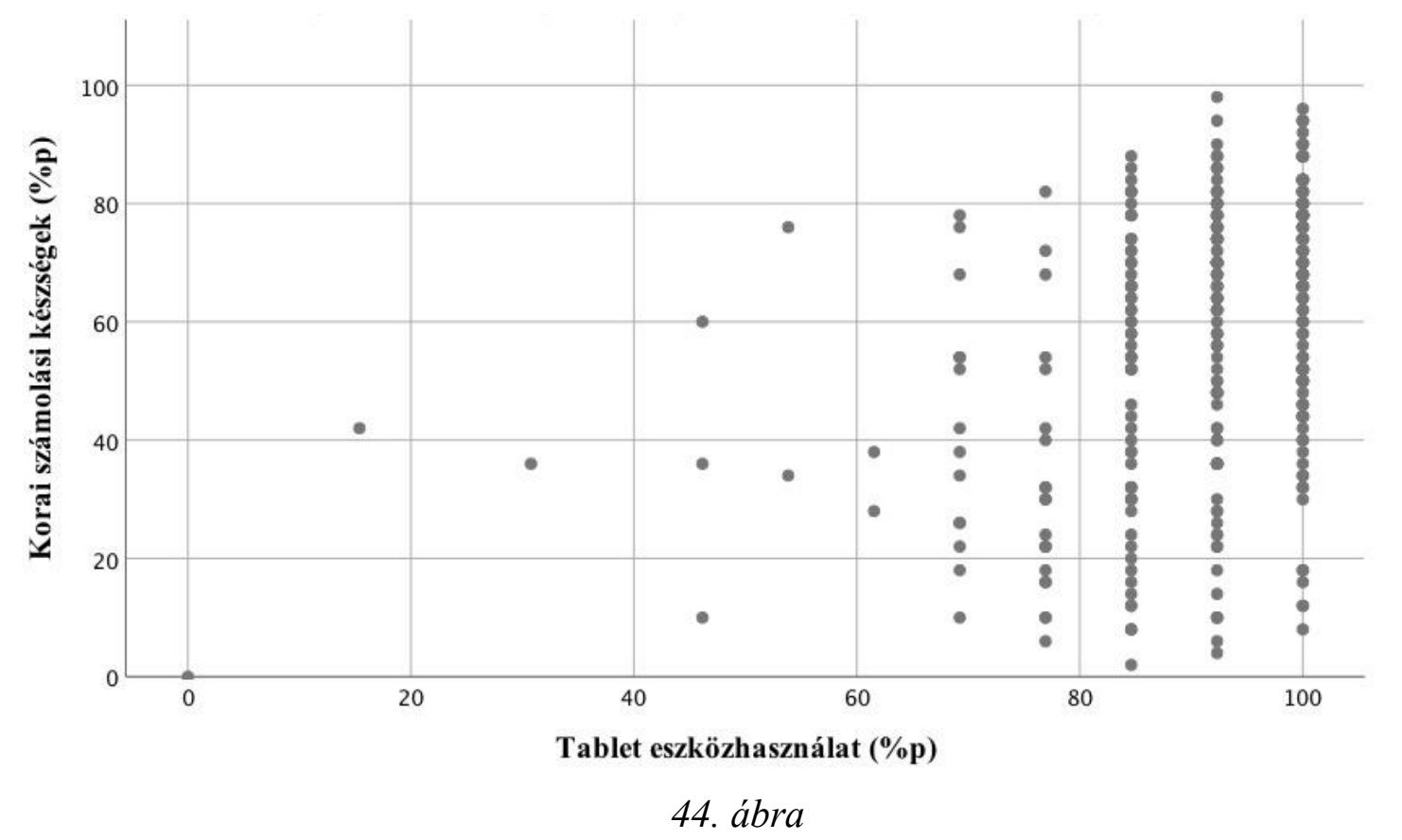

Az óvodás gyermekek a korai numerikus készségek és a tablet eszközhasználat teszteken elért teljesítményének összefüggései

\subsection{Az első tesztváltozat pszichometriai jellemzői első évfolyamon}

\section{Megbizhatóság}

A következőkben az első évfolyamos tanulók közében végzett iskolai bemeneti mérésünk eredményeit mutatjuk be, amely egyben longitudinális vizsgálataink első mérési pontja. Elemzéseinket az 5154 fős első évfolyamos mintán végeztük, adatbázisunk nem tartalmazott hiányzó adatot, a közölt értékek a tejes mintára vonatkoznak. A teljes teszt és a résztesztek reliabilitás-mutatóit és az itemek számát a 14. táblázatban ismertetjük. A teszt megbízhatósága az óvodai méréshez képest alacsonyabb, de továbbra is megfelelő volt (Cronbach- $\alpha=0,89$ ). A résztesztek többségének reliabilitása az alacsony itemszám ellenére, még az elfogadható 0,7-es Cronbach- $\alpha$ érték közelében volt. Ezek közül a legmagasabb a mennyiségek és számok részteszt reliabilitása (Cronbach- $\alpha=0,89$ ), további négy részteszt megbízhatósága hasonló szinten helyezkedik el (Cronbach- $\alpha=0,69-0,71)$. Az elemi számolás dichotóm feladataiból álló részteszt ebben a korcsoportban viszont nem volt eléggé megbízható, a teljes skála reliabilitása alacsony, ezért az elkülönítésmutatók alapján az itemek müködését részletesebben is ellenőriznünk kellett. 
14. táblázat. A teszt és résztesztjeinek megbizhatósága és a tanulók átlagteljesitménye

\begin{tabular}{lcc}
\hline \multicolumn{1}{c}{ Részteszt elnevezése } & Itemek száma & $\begin{array}{c}\text { Megbízhatóság } \\
(\text { Cronbach- } \alpha)\end{array}$ \\
\hline Mennyiségek és számok & 6 & 0,75 \\
Elemi számolás & 5 & 0,59 \\
Relációk & 8 & 0,69 \\
Elemi múveletvégzés & 8 & 0,70 \\
Arab számok felismerése & 5 & 0,69 \\
Arab számok és mennyiségek & 8 & 0,71 \\
\hline Korai numerikus készségek teszt & 40 & 0,89 \\
\hline
\end{tabular}

Az egyes skálák és a hozzájuk tartozó itemek vizsgálatakor, az elkülönítésmutatók alapján 4 itemet kivettünk a további elemzésekből, melyek nélkül lényegesen javult az alskálák reliabilitása. Ezeket a feladatokat nem vontuk be a további elemzésekbe. Ezek közül elsőként az elemi számlálás résztesztjét tekintettük át, amiböl összesen 3 itemet vettünk ki, amelyek mindegyike alacsony, 0,3 alatti elkülönülés-mutatóval rendelkezett. Két feladat magasabb számkörök átlépésére (ED02, ED05), egy pedig visszafelé számolásra vonatkozott (ED09). Ez utóbbit emeltük ki az óvodai mérés korábbi elemzéseinél is. A részteszt megbízhatósága a három feladat nélkül is még alacsonyabb maradt a többi részteszthez képest (Cronbach$\alpha=0,59$ ), viszont a később ismertetett megerősítő faktorelemzésnél magasabb illeszkedésmutatókat kaptunk ezáltal, így további tanulói teljesítményeket és azok eloszlását feltáró elemzéseink a rövidebb skála eredményei alapján készültek. Ezen felül az arab számok felismerése részteszt egy itemét kellett kiemelnünk, amely 3 számjegyü arab számok felismerésére vonatkozott. Ebben a résztesztben egyedül ez az item bírt 0,3 alatti elkülönülésmutatóval, emellett a feladat szórása is kiemelkedően magas volt $(\mathrm{SD}=0,49)$. Az óvodai mérésnél is ezt az itemet kellett kiemelnünk az arab számokat tartalmazó feladataink közül. Az elkülönítésmutatókat részletesen összefoglaltuk a 15. táblázatban, amelyen megtekinthetők az itemek teljes teszthez és a résztesztekhez viszonyított elkülönítésmutatói, továbbá feladatok átlagos pontszámai, a hozzájuk kacsolódó szórások is. A táblázatban mind a 47 tesztitem szerepel. 
15. táblázat. A korai numerikus készségek teszt itemeinek teljes teszthez és résztesztekhez kapcsolódó elkülönitésmutatói, és az itemek prediktív validitása

\begin{tabular}{|c|c|c|c|c|c|c|}
\hline Résztesztek & Itemek & $\begin{array}{l}\text { Átlag } \\
\text { (p) }\end{array}$ & $\begin{array}{l}\text { Szórás } \\
\text { (p) }\end{array}$ & $\begin{array}{c}\text { Elkülönítés- } \\
\text { mutató } \\
\text { Részteszt }\end{array}$ & $\begin{array}{l}\text { Elkülönítés- } \\
\text { mutató } \\
\text { Teljes teszt }\end{array}$ & $\begin{array}{l}\text { Prediktív } \\
\text { validitás (r) }\end{array}$ \\
\hline \multirow{6}{*}{$\begin{array}{l}\text { Mennyiségek } \\
\text { és számok }\end{array}$} & VM01 & 0,89 & 0,31 & 0,51 & 0,38 & 0,18 \\
\hline & VM02 & 0,93 & 0,26 & 0,59 & 0,40 & 0,13 \\
\hline & VM03 & 0,86 & 0,34 & 0,54 & 0,47 & 0,21 \\
\hline & VM04 & 0,88 & 0,32 & 0,57 & 0,44 & 0,20 \\
\hline & VM05 & 0,76 & 0,43 & 0,43 & 0,42 & 0,24 \\
\hline & VM06 & 0,78 & 0,42 & 0,42 & 0,38 & 0,23 \\
\hline \multirow{9}{*}{$\begin{array}{l}\text { Elemi } \\
\text { számolás }\end{array}$} & ED01 & 0,93 & 0,26 & 0,24 & 0,30 & 0,15 \\
\hline & ED02 & 0,72 & 0,45 & 0,29 & 0,31 & 0,23 \\
\hline & ED03 & 0,71 & 0,45 & 0,30 & 0,34 & 0,22 \\
\hline & ED04 & 0,75 & 0,44 & 0,32 & 0,31 & 0,19 \\
\hline & ED05 & 0,69 & 0,46 & 0,27 & 0,25 & 0,17 \\
\hline & ED06 & 0,62 & 0,49 & 0,28 & 0,32 & 0,23 \\
\hline & ED07 & 0,75 & 0,43 & 0,37 & 0,44 & 0,27 \\
\hline & ED09 & 0,44 & 0,50 & 0,08 & 0,09 & 0,07 \\
\hline & ED10 & 0,62 & 0,49 & 0,20 & 0,27 & 0,17 \\
\hline \multirow{10}{*}{ Relációk } & RM01 & 0,92 & 0,28 & 0,23 & 0,30 & 0,16 \\
\hline & RM02 & 0,96 & 0,19 & 0,16 & 0,19 & 0,08 \\
\hline & RM03 & 0,94 & 0,24 & 0,19 & 0,27 & 0,09 \\
\hline & RM04 & 0,87 & 0,34 & 0,19 & 0,24 & 0,12 \\
\hline & RM05 & 0,77 & 0,42 & 0,37 & 0,41 & 0,24 \\
\hline & RM06 & 0,46 & 0,50 & 0,35 & 0,34 & 0,25 \\
\hline & RM07 & 0,77 & 0,42 & 0,44 & 0,46 & 0,34 \\
\hline & RM08 & 0,42 & 0,49 & 0,50 & 0,48 & 0,38 \\
\hline & RM09 & 0,51 & 0,50 & 0,51 & 0,48 & 0,42 \\
\hline & RM10 & 0,25 & 0,43 & 0,44 & 0,40 & 0,35 \\
\hline \multirow{8}{*}{$\begin{array}{l}\text { Elemi } \\
\text { müveletvégzés }\end{array}$} & OM01 & 0,93 & 0,26 & 0,44 & 0,42 & 0,15 \\
\hline & OM02 & 0,89 & 0,32 & 0,43 & 0,43 & 0,20 \\
\hline & OM03 & 0,82 & 0,38 & 0,46 & 0,51 & 0,28 \\
\hline & OM04 & 0,93 & 0,25 & 0,32 & 0,30 & 0,10 \\
\hline & OM05 & 0,94 & 0,23 & 0,39 & 0,37 & 0,15 \\
\hline & OM06 & 0,90 & 0,29 & 0,34 & 0,27 & 0,14 \\
\hline & OM07 & 0,89 & 0,32 & 0,41 & 0,32 & 0,19 \\
\hline & OM08 & 0,76 & 0,43 & 0,39 & 0,38 & 0,26 \\
\hline \multirow{6}{*}{$\begin{array}{l}\text { Arab számok } \\
\text { felismerése }\end{array}$} & VA01 & 0,96 & 0,21 & 0,35 & 0,37 & 0,13 \\
\hline & VA02 & 0,91 & 0,29 & 0,45 & 0,45 & 0,24 \\
\hline & VA03 & 0,85 & 0,35 & 0,50 & 0,51 & 0,29 \\
\hline & VA04 & 0,79 & 0,41 & 0,48 & 0,47 & 0,27 \\
\hline & VA05 & 0,41 & 0,49 & 0,28 & 0,31 & 0,24 \\
\hline & VA06 & 0,71 & 0,45 & 0,44 & 0,46 & 0,31 \\
\hline \multirow{8}{*}{$\begin{array}{l}\text { Arab } \\
\text { számok és } \\
\text { mennyiségek }\end{array}$} & AM01 & 0,95 & 0,23 & 0,26 & 0,28 & 0,14 \\
\hline & AM02 & 0,95 & 0,22 & 0,38 & 0,33 & 0,17 \\
\hline & AM03 & 0,92 & 0,27 & 0,45 & 0,40 & 0,21 \\
\hline & AM04 & 0,81 & 0,39 & 0,46 & 0,45 & 0,27 \\
\hline & AM05 & 0,94 & 0,23 & 0,44 & 0,38 & 0,19 \\
\hline & AM06 & 0,93 & 0,26 & 0,42 & 0,34 & 0,16 \\
\hline & AM07 & 0,77 & 0,42 & 0,42 & 0,42 & 0,25 \\
\hline & AM08 & 0,86 & 0,35 & 0,44 & 0,38 & 0,23 \\
\hline
\end{tabular}

Megjegyzés. A prediktív validitás korrelációi p $<0,001$ szinten szignifikánsak. 


\section{Prediktív-validitás}

Az első évfolyam végi matematika teszt eredményei lehetőséget biztosítanak arra, hogy az itemeket a tanév végi matematika teljesítmény függvényében is megvizsgálhassuk. A 15. táblázat utolsó oszlopában az itemek és a matematika teszt átlageredménye közötti korrelációt tüntettük fel, az itemek prediktív validitásának értékeit. Ez a mérőszám megadja, hogy a korai numerikus készségeket vizsgáló iskolai bemeneti teszt melyik feladatai állnak szorosan kapcsolatban az iskolai matematika teljesítménnyel. A teljes teszt és a résztesztek szintjén történő kapcsolat vizsgálatára külön figyelmet szentelünk a 8.7. alfejezetben, most ezeket az eredményeket kizárólag a korai numerikus készségek itemeinek teszt pszichometriai jellemzéséhez használjuk fel.

A prediktív validitás oszlopában található korrelációs együtthatók értékei minden esetben szignifikánsak, terjedelmük egy itemnek köszönhetően (ED09), amelyet ki is emeltünk a további elemzéseinkből, egészen alacsony korrelációs együtthatóktól a magasabbig esik $(\mathrm{r}=0,07-0,42)$. Az elkülönítésmutatók alapján kiemelt itemeken felül jól látható, hogy a résztesztek elején szereplö, könnyebb feladatok azok, amelyeknek már alacsonyabb ( $\mathrm{r}=0,13$ $0,19)$ a prediktív validitása, a résztesztek végén található, nehezebb feladatok pedig magasabb együtthatókkal rendelkeznek $(r=0,19-0,42)$. Ennek megfelelően minden részteszt feladatainál vegyesek ezek az értékek. A magasabb, 0,3 feletti prediktív validitású feladatok többsége a relációk részteszt második felében, a mennyiségek sorba rendezését vizsgáló feladatoknál volt tapasztalható. Emellett az arab számokat tartalmazó feladatoknál is több magasabb érték látható, főként a két- vagy háromjegyü arab számok felismerésénél, illetve nagyobb mennyiségek arab számkártyákhoz való párosításánál. Az elemi számolási műveletekkel kapcsolatos feladatoknál nem észleltünk kimagasló értékeket, viszont ott a feladatsor elején helyet foglaló összeadási, kiegészítési feladatok (OM02, OM03), valamint a részteszt végén szereplő bontást mérő feladat (OM08) található 0,2-es együttható felett. Az alacsony reliabilitással rendelkező elemi számolás résztesztnél az itemek prediktív validitása is változó.

\section{Nehézségi szintek - Rasch-elemzés}

Az itemek működéséről kaptunk újabb információt a valószínűségi tesztelmélet módszeréhez nyúlva. A korai numerikus készségek teszt itemeinek nehézségi szintjét tovább vizsgáltuk Rasch-elemzés segítségével is. Az elemzés eredményei szerint a teszt személy szeparációs megbízhatóságának értéke 0,999, tehát a tesztfeladatok a minta vizsgálatára alkalmasak voltak. Online tesztünk EAP/PV reliabilitási mutatója 0,86 volt, amely elfogadhatónak tekinthető. 
45. ábra

A korai numerikus készségek teszt személy-item térképe az iskolában

Bal oldalon a feladatok nehézsége és a tanulók képességszintje látható. Minden X 8 tanulót reprezentál. A jobb oldalon az itemek sorszáma található

A tesztben, illetve a 15. táblázatban is szereplő sorrendjük szerint jelenítettük meg az itemeket a 45. ábrán, amely a Rasch-elemzés személy-item térképét ábrázolja. Az ábra bal oldalán az iskolai bemeneti mérésen résztvevő tanulók képességszintjeit találjuk, mellettük a képesség- és 
nehézségszintek skálája található. Az ábrán kivehető, hogy a feladatok többsége túl könnyünek bizonyult a vizsgált korcsoportban. Emellett látható, hogy a magasabb képességszintekről, egykét kivételtől eltekintve, teljesen hiányoznak az itemek. két nehézségi szint területén hiányoznak itemek. Tehát a teszt a vizsgált mintának csak az egyik felét tudta felmérni, a tanulók jelentős része nem kapott a képességinek megfelelő feladatokat. Az is kivehető, hogy a 0,5-ös képességszinten a többi szinthez képest aránytalanul sok feladat szerepelt.

\section{Konstruktum-validitás}

A korai numerikus készségek teszt szerkezetét az iskolai mérésnél is megvizsgáltunk, a konstruktum-validitás ellenőrzéséhez megerősítő faktorelemzést végeztünk. Ezt megelőzően, első lépésként áttekintettük a teszt és résztesztjeinek belső összefüggésrendszerét, amit az 16. táblázatban foglaltunk össze. A Pearson korrelációs elemzések alapján a teljes teszt és mindegyik résztesztje között szignifikáns összefüggés található, mindegyik részteszt magasan korrelál a teljes teszttel $(\mathrm{r}=0,65-0,79)$. Az elemi számolás résztesztjének korrelációs együtthatója marad el a többi résztesztétől. Emellett, magasabb korrelációt most a relációk és az elemi műveletvégzés résztesztjeinél tapasztaltunk, de a két arab számokat tartalmazó részteszt együtthatói is magasak. Mindezeken felül az elemi számolás résztesztje és a többi részteszt között gyengébb összefüggéseket találtunk. A két arab számokat tartalmazó feladatsor az iskolai mérésen is közepes erősségü összefüggést mutatott. A belső struktúra részletesebb leírásához az ellenőrzött CFA-modellek szolgálnak részletesebb információval.

16. táblázat. Az első tesztváltozat és résztesztjeinek korrelációs együtthatói első évfolyamon

\begin{tabular}{lcccccc}
\hline \multicolumn{1}{c}{ Résztesztek } & $1 \mathrm{a}$ & $1 \mathrm{~b}$ & $1 \mathrm{c}$ & $1 \mathrm{~d}$ & $1 \mathrm{e}$ & $1 \mathrm{f}$ \\
\hline 1a - Mennyiségek és számok & - & & & & & \\
1b - Elemi számlálás & 0,34 & - & & & & \\
1c - Relációk & 0,42 & 0,46 & - & & & \\
1d - Elemi múveletvégzés & 0,46 & 0,35 & 0,48 & - & & \\
1e - Arab számok felismerése & 0,40 & 0,38 & 0,48 & 0,46 & - & \\
1f - Arab számok és mennyiségek & 0,39 & 0,33 & 0,44 & 0,50 & 0,54 & - \\
\hline 1 - Korai numerikus készségek teszt & 0,69 & 0,65 & 0,79 & 0,75 & 0,73 & 0,73 \\
\hline
\end{tabular}

Megjegyzés. A korrelációk p $<0,001$ szinten szignifikánsak.

A megerősítő faktorelemzést során több modell illeszkedését teszteltük. Először egy közös faktorba soroltuk a teszt összes itemét, az így kapott 1-dimenziós modell így a korai numerikus készségek közös konstruktuma. A következő modellben két faktort különítettünk el, 
annak tekintetében, hogy azokban szerepelnek-e arab számok vagy sem, az így létrejövő 2dimenziós modellünket is ellenőriztük a mérés adatbázisán. A harmadik modellnél összesen 6 faktort hoztunk létre, az itemeket a részteszteknek megfelelően rendeltük a faktorokhoz, ez a 6-dimenziós CFA-modell szolgált a teszt szerkezetének validálására. A CFA-modellek illeszkedésvizsgálatánál, a szakirodalmi ajánlásnak megfelelően (Muthen, 1993), az átlósan súlyozott négyzetes becslést alkalmaztuk (DWLS - diagonally weighted least squares estimation), és a faktorsúlyoknál a standardizált értékeket közöljük. A három CFA-modell illeszkedésmutatóit az 17. táblázatban mutatjuk be részletesen.

17. táblázat. A CFA-modellek illeszkedésmutatói az iskolai mérésen

\begin{tabular}{rcccccc}
\hline Modell & $\chi^{2}$ & $\mathrm{df}$ & $\mathrm{p}<$ & CFI & TLI & RMSEA (95\% CI) \\
\hline 1-dimenzió & 10192,66 & 740 & 0,001 & 0,845 & 0,836 & $0,050(0,049-0,051)$ \\
2-dimenzió & 8867,73 & 739 & 0,001 & 0,862 & 0,854 & $0,046(0,045-0,047)$ \\
6-dimenzió & 5089,56 & 734 & 0,001 & 0,928 & 0,924 & $0,034(0,033-0,035)$ \\
\hline
\end{tabular}

Megjegyzés. $\mathrm{df}=$ degrees of freedom (szabadságfok); CFI = Comparative Fit Index; TLI = TuckerLewis Index; RMSEA = Root Mean Square Error of Approximation; $\mathrm{CI}=$ confidence interval.

Az első, 1-dimenziós CFA-modell CFI és TLI illeszkedésmutatói az ajánlott határértékeken kívül esnek, miközben az RMSEA értéke épp a megfelelőnek tekinthető 0,05 határértéken áll. Így tehát nem sikerült megerősíteni az egy, korai numerikus készség faktort a teszt feladatai alapján. A második, 2-dimenziós modell fő illeszkedésmutatói is 0,9 alatt helyezkednek el, ennek RMESA értéke már elfogadható, viszont az alacsony CFI értékek miatt ezt a modellünket is el kell vetnünk. Végül, a 6-dimenziós hierarchikus CFA-modellt ellenőriztük, amely leképezi tesztünk hat résztesztjét. Ez a modell már sokkal jobb illeszkedésmutatókkal rendelkezik, a CFI és TLI 0,92 feletti értékei is megfelelőek, közöttük minimális eltérés tapasztalható, továbbá az RMSEA 0,03-as értéke pedig kiválónak tekinthető, utóbbi mutató konfidencia intervalluma is megfelelően alacsony értéket vesz fel.

18. táblázat. CFA-modellek Khi-négyzet különbözöségi próbáinak eredményei az óvodában

\begin{tabular}{rccc}
\hline Modell & $\chi^{2}$ & df & $\mathrm{p}<$ \\
\hline 1-dimenzió és 6-dimenzió & 1994,62 & 15 & 0,001 \\
2-dimenzió és 6-dimenzió & 1585,24 & 14 & 0,001 \\
\hline
\end{tabular}

Megjegyzés. $\chi^{2}=$ Khi-négyzet; $\mathrm{df}=$ degrees of freedom (szabadságfok). 
A három CFA-modell illeszkedésének statisztikai összevetéséhez $\chi^{2}$ különbözőségi teszteket végeztük. Ezek alátámasztották, hogy a harmadik modellünk, amely a korai numerikus készségek teszt alapján készült, illeszkedése szignifikánsan jobb, mint a másik, 1dimenziós és 2-dimenziós modelleké. Ennek megfelelően a magas illeszkedésmutatókkal rendelkező 6-dimenziós modellünk struktúráját elemezzük részletesen, amelyet a 46. ábrán szemléltetünk. Mint az látható, a hat részteszt közül a relációk, elemi műveletvégzés, arab számok felismerése és az arab számok és mennyiségek skálák 0,84-0,88-as súllyal kapcsolódnak a korai numerikus készségek faktorához, míg a mennyiségek és számok, valamint az elemi számlálás részteszt egyaránt 0,74 -as súllyal csatlakozik ehhez a faktorhoz.

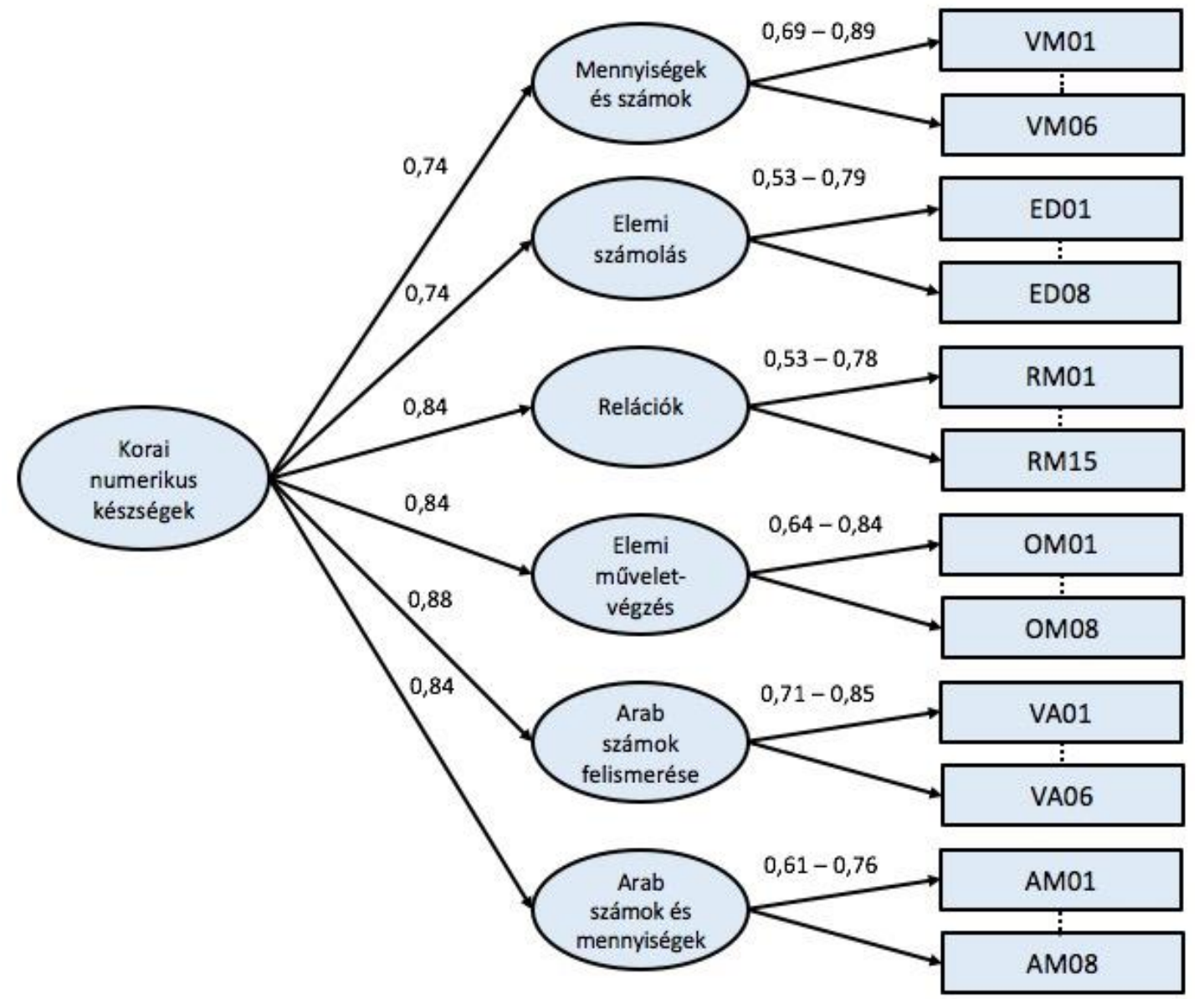

46. ábra

A korai numerikus készségek teszt 6-dimenziós CFA-modellje (1. tesztváltozat)

Tekintve, hogy megerősítő faktorelemzésünket az itemek szintjén végeztük, lehetőségünk van a teszt feladatainak részletesebb vizsgálatára is az egyes alskálákon belül. A mennyiségek és számok, valamint a két arab számokat tartalmazó részteszt itemei egyaránt 
magas súllyal kapcsolódnak az érintett faktorokhoz. Az ide tartozó itemek faktorsúlyai 0,6 és 0,9 közötti értékek mentén csoportosulnak. A többi részteszt esetében azonosítható pár kilógónak tekinthető item, amelyek alacsonyabb faktorsúllyal csatlakoznak a résztesztek faktoraihoz. Ilyen az elemi számlálás egyik visszafelé számolást mérő feladata, a relációk részteszt egyik feladata, továbbá az elemi müveletvégzésnél az egyik feladat, amelynél az elemeket két egyenlő halmazba kell rendezni. Bár ezek az együtthatók 0,5 feletti értéken állnak, ha a faktorelemzéseinkből kivennénk ezeket, akkor tovább javítható lenne mindhárom CFAmodellünk illeszkedése. Azonban a korábban ismertetett reliabilitás-vizsgálatkor már az elkülönítésmutatók alapján kiszelektált itemek mellett további feladatok eltávolítása, a résztesztek belüli változtatások a teljes teszt és az érintett résztesztek reliabilitás-mutatóinak lényeges csökkenését vonnák magukkal, így további feladatok kivételétől eltekintünk.

\section{Átlagteljesitmények és eloszlások}

A teszt és résztesztek eredményeit és szórását az 19. táblázatban ismertetjük. A tanulók teszten elért átlagteljesítménye 80,45 \% volt. A résztesztek közül az elemi müveletek és az arab számok és mennyiségek résztesztek 88,21-89,02 \%p-os átlagteljesítményei voltak legmagasabbak, melyekhez alacsonyabb (17,99-17,59 \%p) szórás kapcsolódott. Az elemi számolás $(72,65 \%$ p) és a relációk $(23,71 \%$ p) részteszteken alacsonyabbak voltak az átlagteljesítmények, lényegesen nagyobb szórás mellett (26,55 \%p és 23,71\%p).

19. táblázat. Az elsö évfolyamos tanulók korai numerikus készségek teszten és a részteszteken elért eredményei (1. tesztváltozat)

\begin{tabular}{lcc}
\hline \multicolumn{1}{c}{ Résztesztek } & Átlag $(\% \mathrm{p})$ & Szórás $(\% \mathrm{p})$ \\
\hline Mennyiségek és számok & 85,1 & 23,5 \\
Elemi számolás & 72,7 & 26,6 \\
Relációk & 63,0 & 23,7 \\
Elemi műveletvégzés & 88,2 & 18,0 \\
Arab számok felismerése & 84,5 & 23,4 \\
Arab számok és mennyiségek & 89,0 & 17,6 \\
\hline Korai numerikus készségek teszt & 80,5 & 15,7 \\
\hline
\end{tabular}


20. táblázat. A teszt és résztesztjeinek eloszlásmutatói első évfolyamon (1. tesztváltozat)

\begin{tabular}{lcccc}
\hline \multicolumn{1}{c}{ Résztesztek } & Ferdeség & Lapultság & $\begin{array}{c}\text { Kolmogorov- } \\
\text { Smirnov tesz }\end{array}$ & $\mathrm{p}<$ \\
\hline Mennyiségek és számok & $-2,26$ & 5,14 & 0,28 & 0,01 \\
Elemi számolás & $-0,74$ & $-0,44$ & 0,22 & 0,01 \\
Relációk & $-0,24$ & $-0,70$ & 0,12 & 0,01 \\
Elemi műveletvégzés & $-1,99$ & 4,16 & 0,29 & 0,01 \\
Arab számok felismerése & $-1,77$ & 2,86 & 0,32 & 0,01 \\
Arab számok és mennyiségek & $-2,33$ & 6,14 & 0,29 & 0,01 \\
\hline Korai numerikus készségek teszt & $-1,49$ & 2,46 & 0,15 & 0,01 \\
\hline
\end{tabular}

Megjegyzés. Ferdeség (szimmetria) = Skewness; Lapultság = Kurtosis; $\mathrm{p}=$ szignifikanciaszint.

Online tesztünk és résztesztjeinek eloszlását egymintás Kolmogorov-Smirnowpróbával ellenőriztük, továbbá az eloszlási görbék ferdeség és lapultság mutatóit is megnéztük. Az eloszlásvizsgálatok eredményeit a 20. táblázatban foglaltuk össze. Amint az a kiemelkedően magas átlageredmények alapján is várható volt, a teljes teszt, és a résztesztek is szignifikánsan eltérnek a normál eloszlástól. Kolmogorov-Smirnow-próbán legalacsonyabb értéket elérő relációk részteszt sem felelt meg a normál eloszlás követelményeinek.

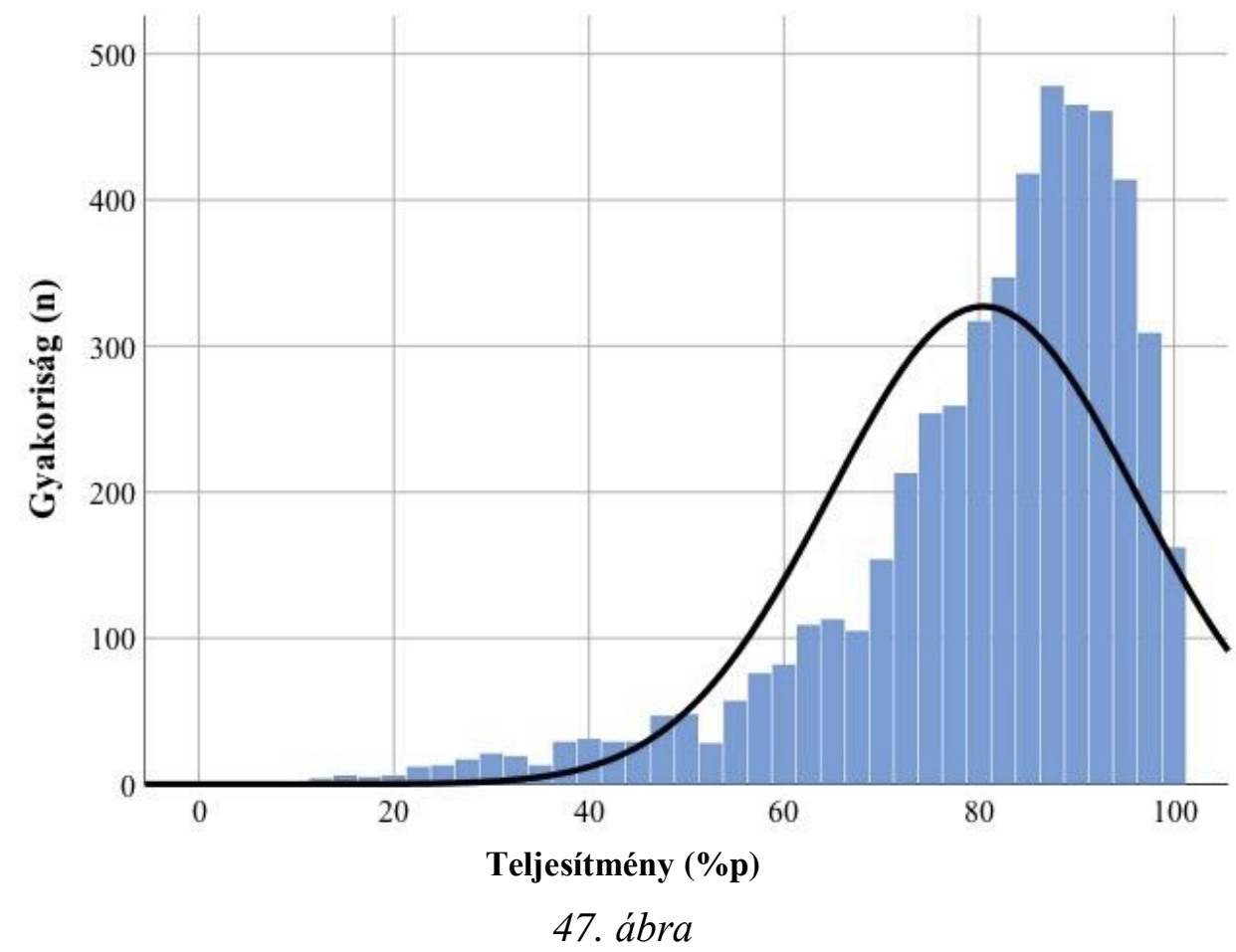

Az első évfolyamos tanulók teljesitényének eloszlása a korai numerikus készségek teszten

(1. tesztváltozat) 
Az iskolai bemeneti mérésen alkalmazott korai numerikus készségek teszten elért eredmények eloszlását a 47. ábrán mutatjuk, melyen viszonyítási alapként a normál eloszlás elméleti görbéjét is elhelyeztük. Az átlagteljesítmények erősen jobbra tolódnak, a Raschelemzés eredményeit megerősítve elmondható, hogy a jobb képességü gyermekeket már nem mérte a teszt. Emellett az is kivehető, hogy gyengébb tanulói eredmények alig születtek.
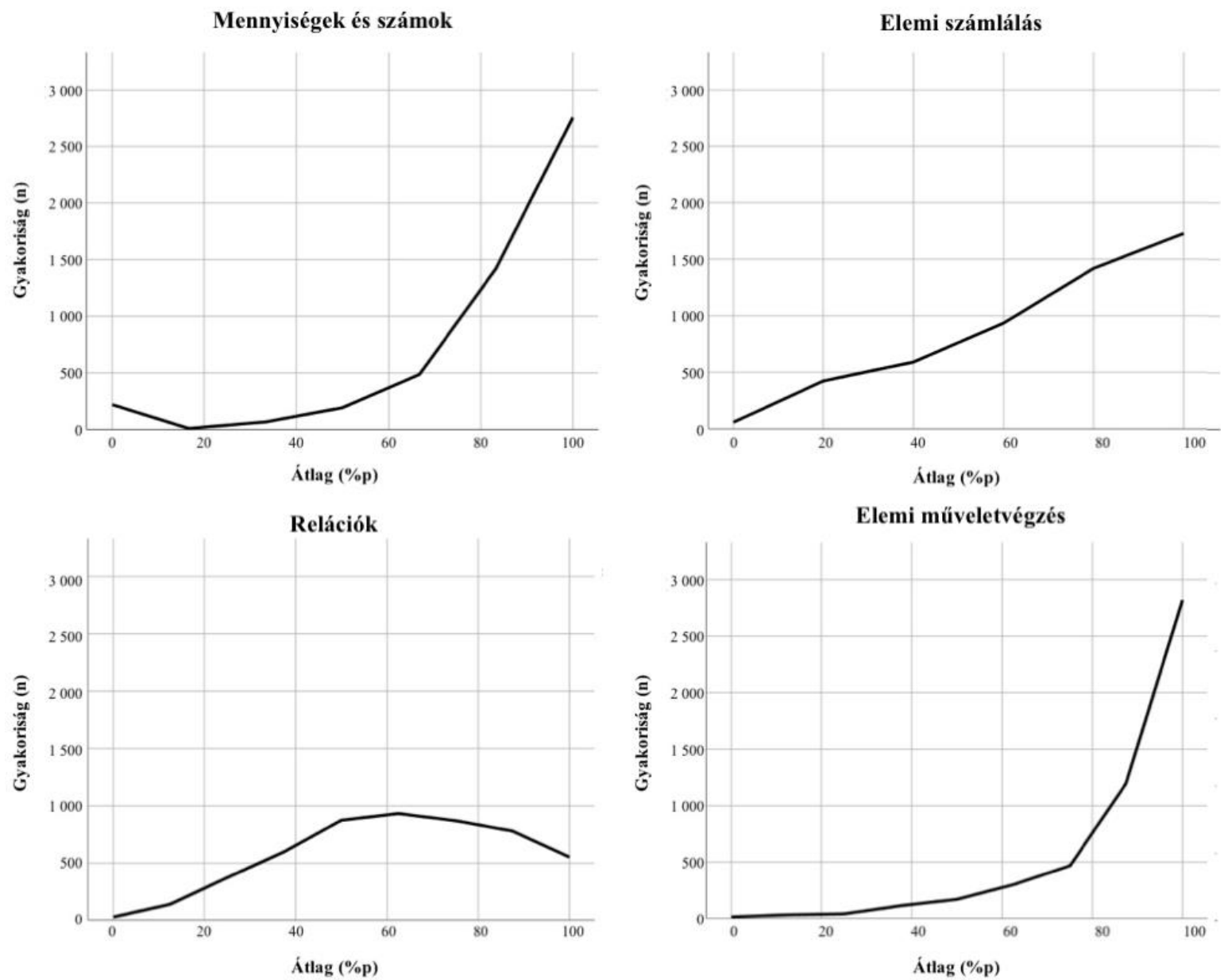

Elemi müveletvégzés

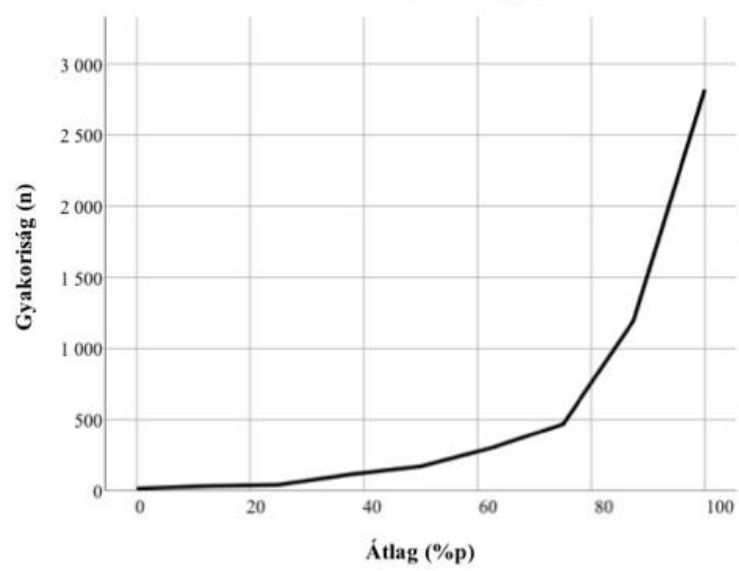

Arab számok felismerése
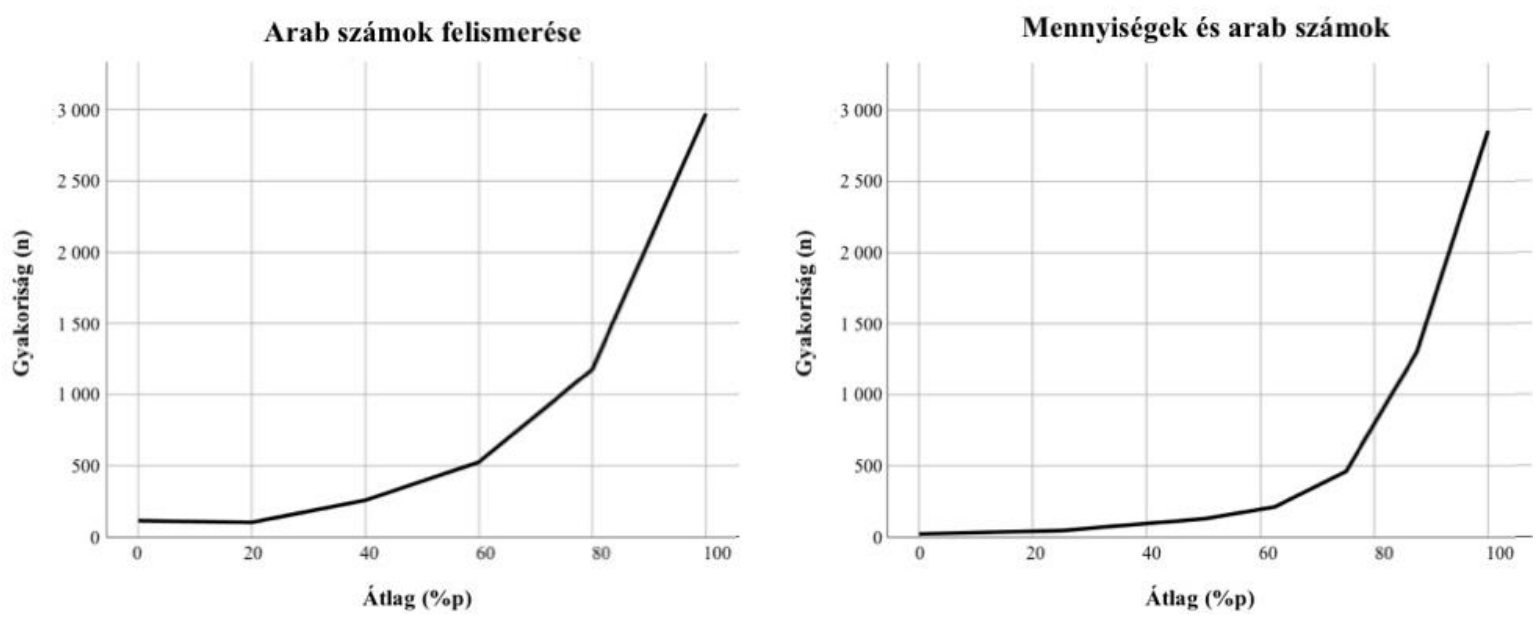

48. ábra

Az elsö évfolyamos tanulók átlagteljesitményének eloszlása

a korai numerikus készségek teszt résztesztjein (1. tesztváltozat) 
A résztesztek eloszlási görbéin (48. ábra) végig tekintve jól láthatóak az eröteljes jobbratolódások. A teszt elején helyet kapó mennyiségek és számok részteszten látunk egy kisebb csoportot, akik nagyon alacsonyan teljesítettek. Továbbá a relációk teszt eloszlási görbéje közelít egyedül a szimmetrikushoz, azonban ebben az esetben is jobbra tolódó tendenciát vehetünk észre. Az elemi számolás részteszt eloszlása érdekes tendenciát mutat, amely miatt az itemeken elért teljesítményt ismét egyesével is részletesen megvizsgáltuk. Az első feladatra a tanulók 93 \%-a válaszolt helyesen, ezt követően nagyobb visszaesés tapasztalható, a második és harmadik feladatra $72 \%$-os és $71 \%$-os arányban adtak helyes választ, majd a negyedik feladatnál már 75 \% volt a helyes válaszok aránya. Így nem figyelhető meg az a tendencia, ami az óvodai mérésen.

\section{Tesztelés ideje és eszközhasználat}

A korai numerikus készségek teszt kitöltésével eltöltött időt megnéztük az iskolai mérések esetében is. A tesztben szereplő 47 feladat áltagos kitöltési ideje összesen 18,8 perc, melynek szórása 6,8 perc volt. A teszt egészét nézve, az azonosító oldaltól a záró képernyőig átlagosan 22,2 perc telt el, ennek szórása magasabb, 9,46 perc.

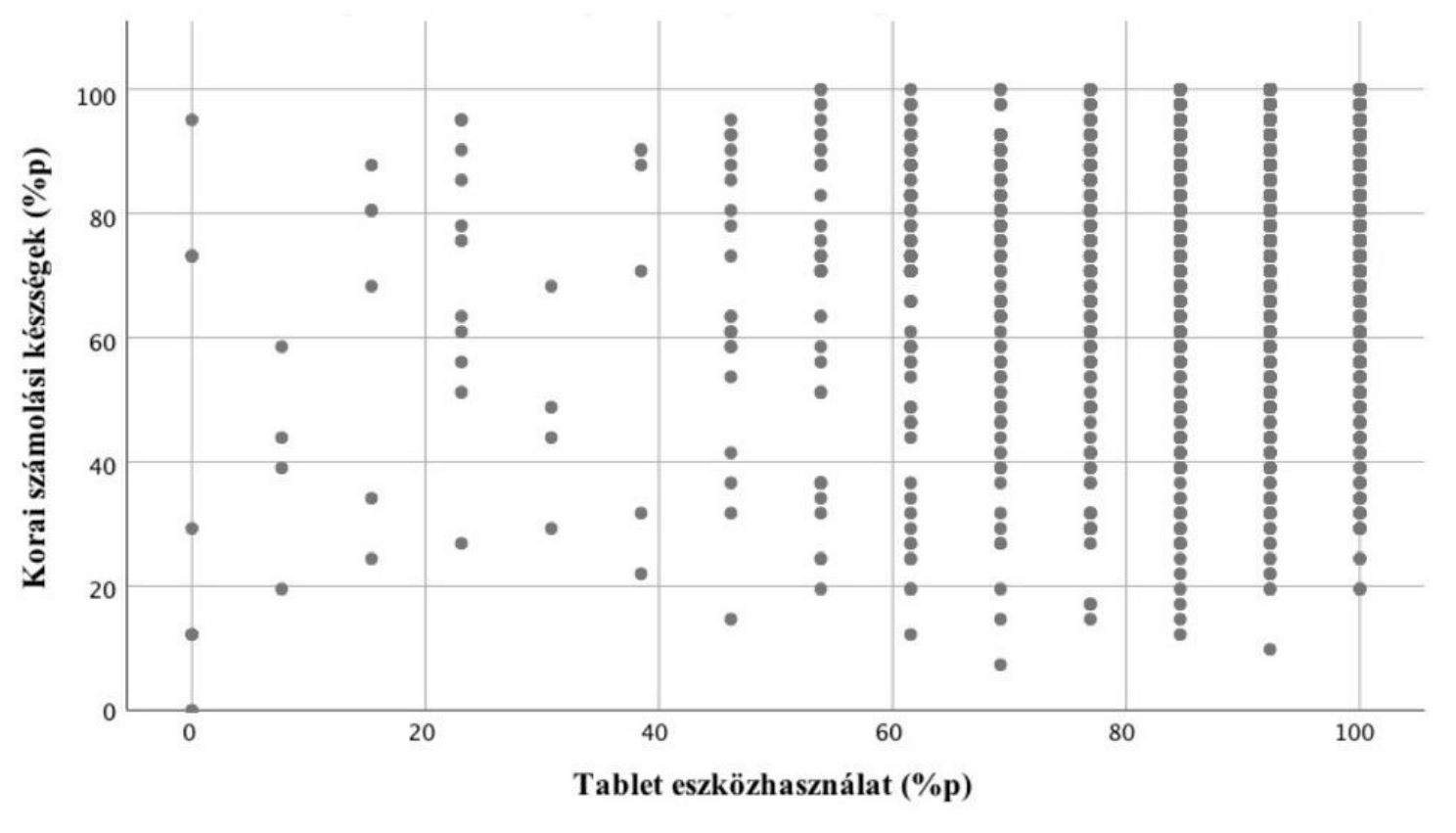

49. ábra

Az első évfolyamos tanulók a korai numerikus készségek és a számitógépes-egér használat teszteken elért teljesitménye

A korai numerikus készségek teszt felvétele elött ebben az esetben is részt vett az összes tanuló egy eszközhasználatot mérő, és egyben gyakorló, feladatsor kitöltésében. Az első 
évfolyamos számítógépes-egér teszten a tanulók 91,6 \%p-os átlagteljesítményt értek el, közepes mértékü szórás mellett $(12,5 \% \mathrm{p})$. Az eredmények arra utalnak, hogy az elsős gyermekeknek nem okozott gondot a feladatok asztali számítógépen történő megoldása. A számítógépes-egér teszt és a korai numerikus készségek teszt között mégis szignifikáns korreláció áll fenn $(\mathrm{r}=0,29 ; \mathrm{p}<0,01)$. Az összefüggés miatt leszürtük a mintánkat azokra a tanulókra, akik 50\% alatti teljesítményt értek el a számítógépes-egér használat teszten $(\mathrm{N}=82)$. Az összefüggést újra ellenőrizve, a két teszt közötti korreláció nem változott $(r=0,27 ; p=0,04)$, inkább enyhén csökkent. Ugyanennek a 82 tanulónak a tesztfelvétel idejét megnézve ugyanakkor látható, hogy számukra valamivel hosszabb időbe telt a korai numerikus készségek teszt feladatainak megoldása. A feladatok megoldási ideje esetükben átlagosan 20,9 perc volt, a teljes tesztben átlagosan 24,5 percet töltöttek.

\subsection{A második tesztváltozat pszichometriai jellemzői óvodában}

Megbizhatóság

A korai numerikus készségek online mérőeszköz második változatának a 2017-es óvodai mérésen kapott pszichometriai jellemzőivel folytatjuk eredményeink ismertetését, amelyet a teszt átalakításának következtében összesen 34 item és négy részteszt megbízhatóságának elemzésével kezdünk. A korai numerikus készségek teszt és résztesztjeinek megbízhatóságát a 21. táblázatban mutatjuk be. A teszt megbízhatósága az előző óvodai méréshez képest csökkent, de továbbra is elfogadható volt (Cronbach- $\alpha=0,83)$. A résztesztek tekintetében viszont változatos értékeket kaptunk, többségük reliabilitása elfogadható volt, viszont az arab számok felismerése részteszt Cronbach- $\alpha$ értéke 0,6 alá csökkent.

\section{A korai numerikus készségek teszt és résztesztjeinek megbizhatósága az óvodában} (2. tesztváltozat)

\begin{tabular}{lcc}
\hline \multicolumn{1}{c}{ Résztesztek } & Itemek száma & $\begin{array}{c}\text { Megbízhatóság } \\
(\text { Cronbach- } \alpha)\end{array}$ \\
\hline Elemi múveletvégzés & 11 & 0,75 \\
Elemi számolás & 11 & 0,73 \\
Arab számok felismerése & 6 & 0,59 \\
Arab számok és mennyiségek & 6 & 0,69 \\
\hline Mennyiségek és arab számok (összevont) & 12 & 0,73 \\
\hline Korai numerikus készségek teszt & 34 & 0,83 \\
\hline
\end{tabular}


Az átdolgozott új tesztváltozat megbízhatóságának ellenőrzésekor megvizsgáltuk az egyes itemek elkülönítésmutatóit. Az egy tizedesjegyre kerekített elkülönítésmutatókat megoszlását az 50. ábrán helyeztük el. Az első tesztváltozathoz képest csökkentek a mutatók értékei, lényegesen megnőtt a 0,1-es és 0,2-es mutatóval rendelkező itemek száma, azonban az itemek közel 80\%-a eléri a 0,3-as küszöbértéket. Az elemi müveletvégzés egyetlen elvételt mérő feladata (BAC06) érte el a legalacsonyabb mutatót $(0,12)$ a teljes teszthez viszonyítva, saját részteszténél ez valamivel magasabb $(0,19)$. A résztesztekre vonatkoztatott elkülönítésmutatók értékei az arab számok felismerése résztesztnél (VA01) található 0,2 alatt, a részteszteknél a többi item megközelíti 0,3-as értéket. Mivel a teljes teszt mindössze 34 itemből átt, a most kapott értékeket a teszt javításához felhasználjuk, viszont a további elemzésekhez az összes itemet és a teljes skálákat felhasználjuk. A reliabilitás-vizsgálat résztesztekre és teljes tesztre vonatkozó adatokat tartalmazó táblázatát a 7 . mellékletben helyeztük el.

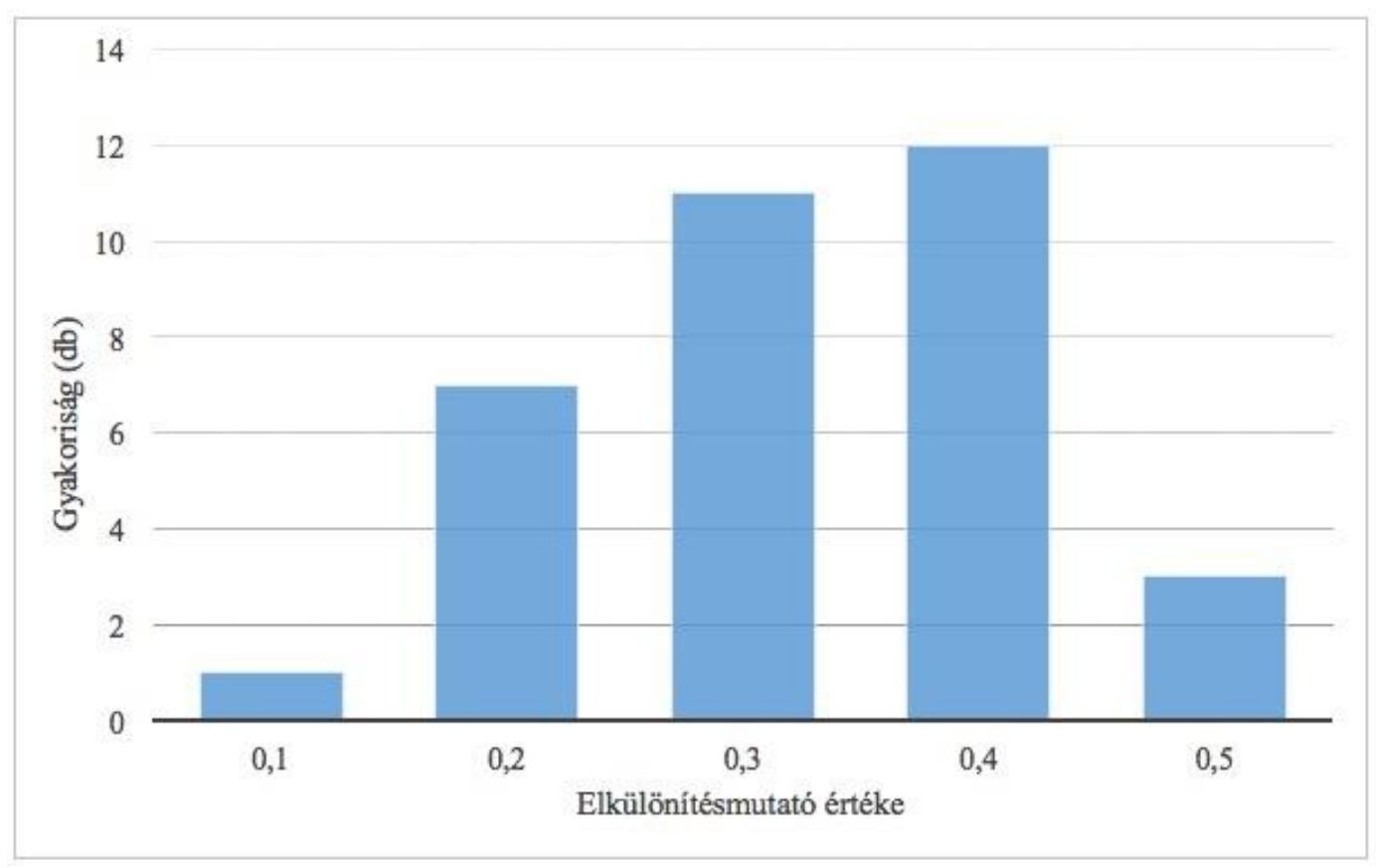

50. ábra

Az itemek elkülönités-mutatóinak eloszlási gyakorisága óvodában (2. tesztváltozat)

\section{Nehézségi szintek - Rasch-elemzés}

A tesztfeladatok nehézségi szintjének, müködésének feltáráshoz újból Rasch-elemzést végeztünk. A teljes korai numerikus készségek tesztre vonatkozóan lefuttatott elemzésen a teszt személy szeparációs reliabilitása 0,992 volt, így a feladatok viselkedése alkalmasnak tekinthető a minta vizsgálatára. A teszt EAP/PV reliabilitása 0,834 volt. 
$x x x x x x x x x x x x x x x x x x x x x x x x x x x x x x x x x x x x \mid$

$x x x x x x x x x x x x x x x x x x x x x x x x x x x x x x x x x x x x x \mid 12 \quad 13$

$1 \quad x x x x x x x x x x x x x x x x x x x x x x x x x x x x x x x x x x x x x x x x x x \mid$

$x x x x x x x x x x x x x x x x x x x x x x x x x x x x \mid$

$x x x x x x x x x x x x x x x x x x x x x x x x x x x x x x x x x x x x x x \mid 8 \quad 17$

$x x x x x x x x x x x x x x x x x x x x x x x x x x x x x x x x x \mid$

$x x x x x x x x x x x x x x x x x x x x x x x x x x x x x x x x x x x \mid$ $x x x x x x x x x x x x x x x x x x x x x x x x x x x x x x \mid$ $x x x x x x x x x x x x x x x x x x x x x x x x x x x x x x x \mid 28$ $x x x x x x x x x x x x x x x x x x x x x x x x x x x \mid$

0 $x x x x x x x x x x x x x x x x x x x x x x \mid$ $x x x x x x x x x x x x x x x x x x \mid$ $x x x x x x x x x x x x x x \mid 5 \quad 26 \quad 31$ $x x x x x x x x x x x x x x x x x x x \mid 34$ $x x x x x x x x x x x x \mid$ $\begin{array}{lll}x x x x x x \mid 4 & 25\end{array}$ $x x x x x x x \mid 1 \quad 3$

$-1$ $x x x x x x \mid 11$ $x x x x x \mid 2$ $x \times \mid 2432 \quad 33$ $x x x \mid 10$ $x x \mid 30$ $\mathrm{XI}$ $x \times 1$ $x \mid 67$

$$
\text { 51. ábra }
$$

A korai numerikus készségek teszt 2. változatának személy-item térképe az óvodában. Bal oldalon a feladatok nehézsége és a tanulók képességszintje látható. Minden X 0,4 tanulót reprezentál. A jobb oldalon az itemek sorszáma található. 
A Rasch-elemzésünk eredményei alapján készült személy-item térképen (51. ábra) láthatóak a teszt itemei a tesztben szereplő sorrendjük szerint számozva, azok nehézségi szintje, valamint a vizsgálatban résztvevő óvodás gyermekek képességszintjei. Ez alapján elmondható, hogy az itemek egy könnyebb, -1 körüli, és egy nehezebb, 2-höz közeli nehézségi szinten csoportosulnak, a két feladathalmaz között kevés item helyezkedik el. Emellett a mintában szereplö, jobb képességü gyermekeket nem kaptak a képességszintjüknek megfelelő feladatokat, miközben több feladat is könnyünek bizonyult az óvodás korcsoportban, ezek között föként az elemi műveletvégzés, valamint a mennyiségek és arab számok részteszt egyes feladatait találjuk.

\section{Konstruktum-validitás}

A korai numerikus készségek teszt második változatának belső felépítését is elemeztük. A négy résztesztből felépülő teszt strukturális validitásának ellenőrzéséhez megerősítő faktorelemzést végeztünk, amelyet megelőzően a teszt és résztesztjeinek összefüggéseit is megvizsgáltuk Pearson korrelációs elemzéssel. Az elemzések együtthatói a 22. táblázatban szerepelnek. A teszttel mindegyik részteszt szignifikáns korrelál, a korrelációs együtthatók magasak $(\mathrm{r}=0,60$ 0,78). Arab számok és mennyiségek résztesztnél tapasztaltunk 0,6-os értéket. És ugyanez a részteszt az elemi müveletvégzéssel is korrelált $(\mathrm{r}=0,17)$. A résztesztek közötti összefüggések korrelációs együtthatói a többi esetben közepes szintűek voltak $(r=0,3-0,5)$.

\section{2. táblázat. A második tesztváltozat és résztesztjeinek korrelációs együtthatói az óvodában}

\begin{tabular}{lccccc}
\hline \multicolumn{1}{c}{ Résztesztek } & $1 \mathrm{a}$ & $1 \mathrm{~b}$ & $1 \mathrm{c}$ & $1 \mathrm{~d}$ & 1 \\
\hline $1 \mathrm{a}$ - Elemi számlálás & - & & & & \\
$1 \mathrm{~b}$ - Elemi múveletvégzés & $0,30^{* *}$ & - & & & \\
$1 \mathrm{c}$ - Arab számok felismerése & $0,47^{* *}$ & $0,31^{* *}$ & - & & \\
$1 \mathrm{~d}$ - Arab számok és mennyiségek & $0,42^{* *}$ & $0,17^{*}$ & $0,42^{* *}$ & - & \\
\hline 1 - Korai numerikus készségek teszt & $0,78^{* *}$ & $0,73 * *$ & $0,70^{* *}$ & $0,60 * *$ & -
\end{tabular}

Megjegyzés. $*=\mathrm{p}<0,05 ; * *=\mathrm{p}<0,01$ szinten szignifikáns.

Megerősítő faktorelemzéssel ismételten három CFA-modell illeszkedését ellenőriztük, melyek közül a korábbiakhoz hasonlóan egy közös skálára helyezett összes item alkotta az elsőt, a második modellben az arab számokat tartalmazó két részteszt és a másik két részteszt itemeit helyeztük egy-egy faktorra, végül a harmadik modell a tesztben szereplő négy résztesztnek megfelelően épült fel. 
23. táblázat. A korai numerikus készségek teszt megerösitő faktorelemzésének eredményei

\begin{tabular}{rcccccc}
\hline Modell & $\chi^{2}$ & $\mathrm{df}$ & $\mathrm{p}<$ & CFI & TLI & RMSEA (95\% CI) \\
\hline 1-dimenzió & 1718,28 & 527 & 0,001 & 0,850 & 0,841 & $0,081(0,077-0,086)$ \\
2-dimenzió & 1557,30 & 526 & 0,001 & 0,870 & 0,862 & $0,076(0,071-0,080)$ \\
4-dimenzió & 1266,83 & 523 & 0,001 & 0,907 & 0,900 & $0,064(0,060-0,069)$ \\
\hline
\end{tabular}

Megjegyzés. $\mathrm{df}=$ degrees of freedom (szabadságfok); CFI = Comparative Fit Index; TLI = Tucker Lewis Index; RMSEA = Root Mean Square Error of Approximation.

A modellek illeszkedésmutatóit a 23. táblázatban közöljük. Eredményeink alapján az első két modellünket el kell vetnünk, mivel illeszkedésmutatóik kívül esnek az ajánlott küszöbértékeken, az utolsó, résztesztek szerinti, 4-dimenziós modell illeszkedése épp elfogadható, a CFI értéke a még elfogadható érték felett, az RMSEA kevéssel a jónak tekinthető 0,05 felett található. Ezt támasztják alá a $\chi^{2}$ különbözőségi tesztek eredményei is, amiket a 24 . táblázatban foglaltunk össze. A 4-dimenziós modell illeszkedése szignifikánsan erősebb volt. A korai numerikus készségek struktúráját leképező CFA-modellünk ábráján találhatók a faktorelemzés során kapott faktorsúlyok, itt látható, hogy a négy részteszt szorosan kapcsolódik a korai numerikus készségek közös, egy szinttel feljebb elhelyezkedő faktorához. A részteszteket alkotó itemek együtthatói az elemi számolás, az arab számok felismerése, valamint az arab számok és mennyiségek faktorainál egyformán magas értéken állnak, az elemi müveletvégzésnél találtunk egy kilógó feladatot, amelynek kivétele erősítene a faktor korai numerikus készségekhez való, jelenleg 0,73-as kapcsolatán, továbbá javítana a CFA-modell egészének illeszkedésén is (52. ábra), azonban a teszt eleve alacsony feladatszáma miatt végül benne maradt az elemzéseinknél.

24. táblázat. CFA-modellek Khi-négyzet különbözöségi próbáinak eredményei az óvodában

\begin{tabular}{rccc}
\hline Modell & $\chi^{2}$ & $\mathrm{df}$ & $\mathrm{p}<$ \\
\hline 1-dimenzió és 4-dimenzió & 240,71 & 4 & 0,001 \\
2-dimenzió és 4-dimenzió & 150,34 & 3 & 0,001 \\
1-dimenzió és 2-dimenzió & 76,89 & 1 & 0,001 \\
\hline
\end{tabular}

Megjegyzés. $\chi^{2}=$ Khi-négyzet; $\mathrm{df}=$ degrees of freedom (szabadságfok). 


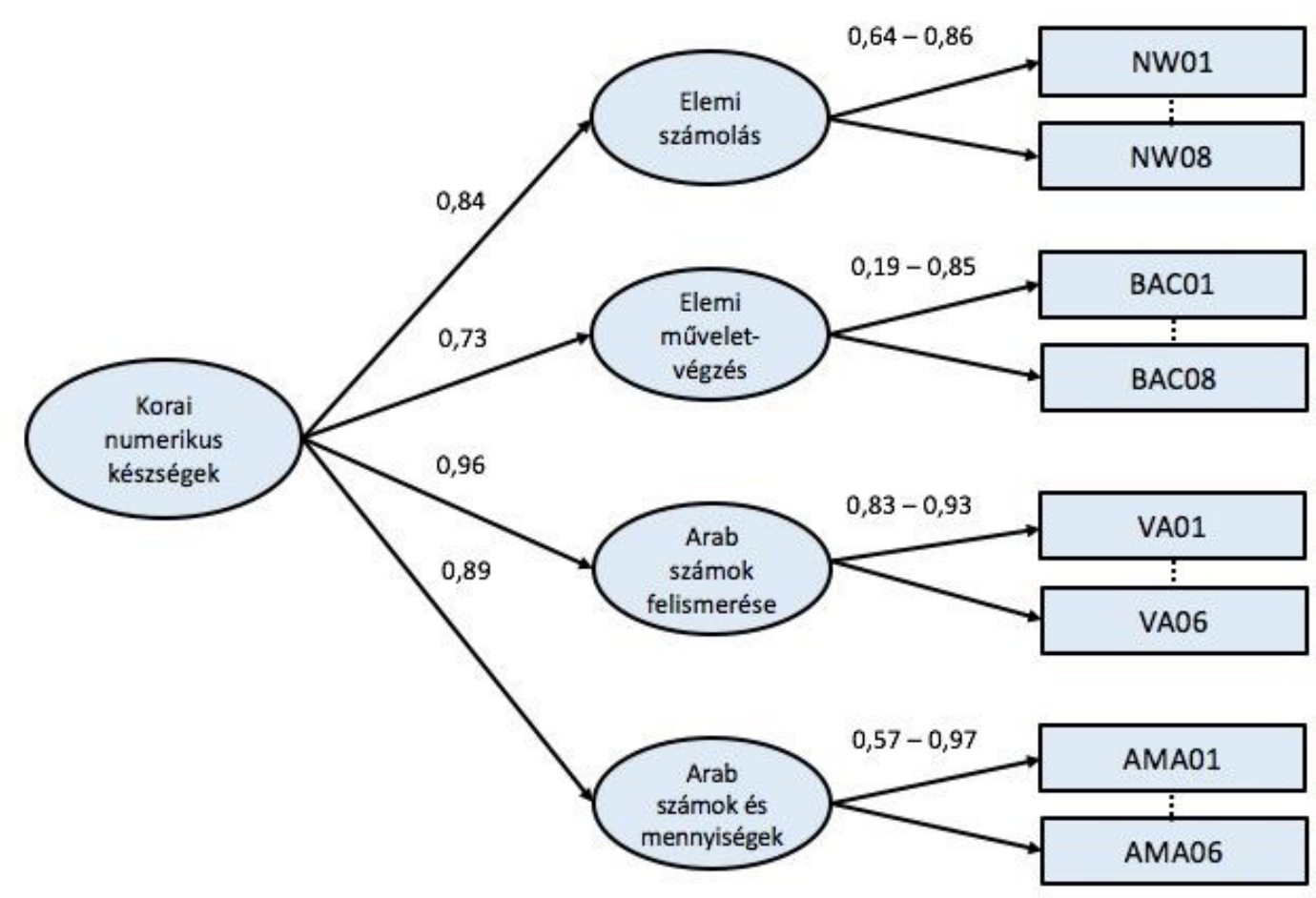

52. ábra

A korai numerikus készségek teszt második tesztváltozatának faktor struktúrája óvodában

\section{Átlagteljesitmények és eloszlások}

Az óvodás gyermekek teljes teszten és részteszteken nyújtott átlagteljesítményét és szórásait a 25. táblázatban ismertetjük. A mérésen $62,9 \%$ p volt az átlagteljesítmény, amely az elemi számolás átdolgozott formáján nyújtott 36,2 \%p-os alacsony teljesítmény eredményezett, amelynek szórása a többi részteszthez képest magasabb is volt. A további három részteszten a magas teljesítményt nyújtottak a gyermekek. Az elemi müveletvégzés szintén továbbfejlesztett tesztjén 75,4\%p, az arab számok felismerése részteszten 70,2\%p, az arab számok és mennyiségek részteszten $82,8 \%$ p volt az átlageredmény.

25. táblázat. Az óvodás korú gyermekek korai numerikus készségek teszten és a részteszteken elért eredményei (2. tesztváltozat)

\begin{tabular}{lcc}
\hline \multicolumn{1}{c}{ Résztesztek } & Átlag $(\% \mathrm{p})$ & Szórás $(\% \mathrm{p})$ \\
\hline Elemi műveletvégzés & 75,4 & 21,3 \\
Elemi számolás & 36,2 & 24,6 \\
Arab számok felismerés & 70,2 & 23,8 \\
Arab számok és mennyiségek & 82,8 & 23,2 \\
\hline Korai numerikus készségek teszt & 62,9 & 16,4 \\
\hline
\end{tabular}


A teljes teszt eloszlása, amit az 53. ábrán láthatunk ránézésre közel áll a normál eloszláshoz, azonban attól a Kolmogorov-Smirnow-próba eredményei alapján szignifikánsan eltér. Az eloszlás már az óvodában is láthatóan enyhén jobbra tolódik, kirívóan alacsony pontszámot egyetlen felmért óvodás sem ért el.

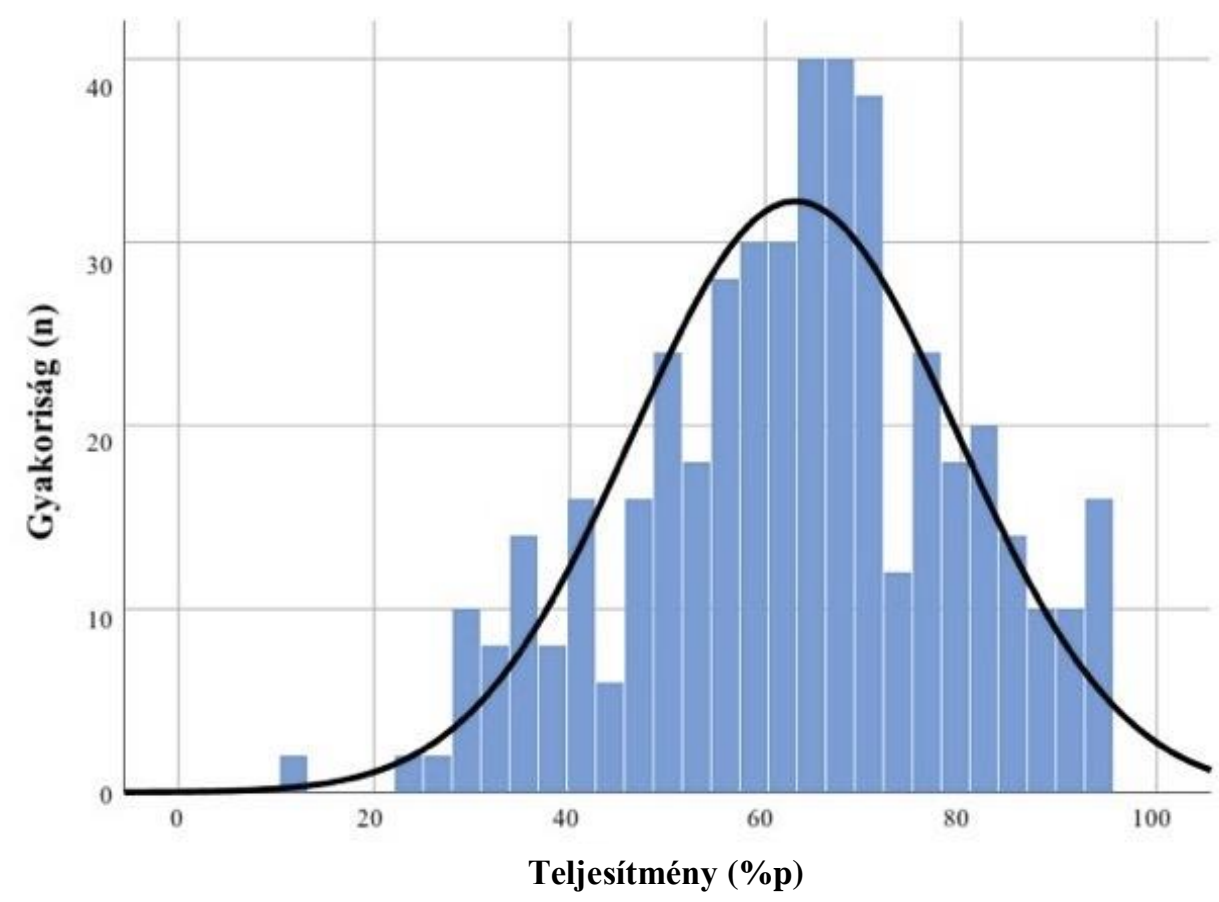

53. ábra

Az óvodás gyermekek teljesitényének eloszlása a korai numerikus készségek teszt második tesztváltozatának résztesztjein

Az egyes résztesztek eloszlásait (54. ábra) szintén összevetettük a normál eloszlással, és minden esetben szignifikánsan eltértek attól. Az elemi müveletvégzés esetében jobbra tolódás tapasztalható, miközben az elemi számolás résztesztjénél jól láthatóan balra tolódnak az átlageredmények, így ez a részteszt a korábbi, dichotóm verzióhoz képest nehezebbnek bizonyult az óvodásoknak. A két arab számokat tartalmazó részteszt eredményei erőteljesen jobbra tolódnak, a jobb képességü gyermekeket már nem mérte fel ez a kettő részteszt. Az eloszlásvizsgálatok részletes eredményeit résztesztekre bontva a 26. táblázatban foglaltuk össze. 

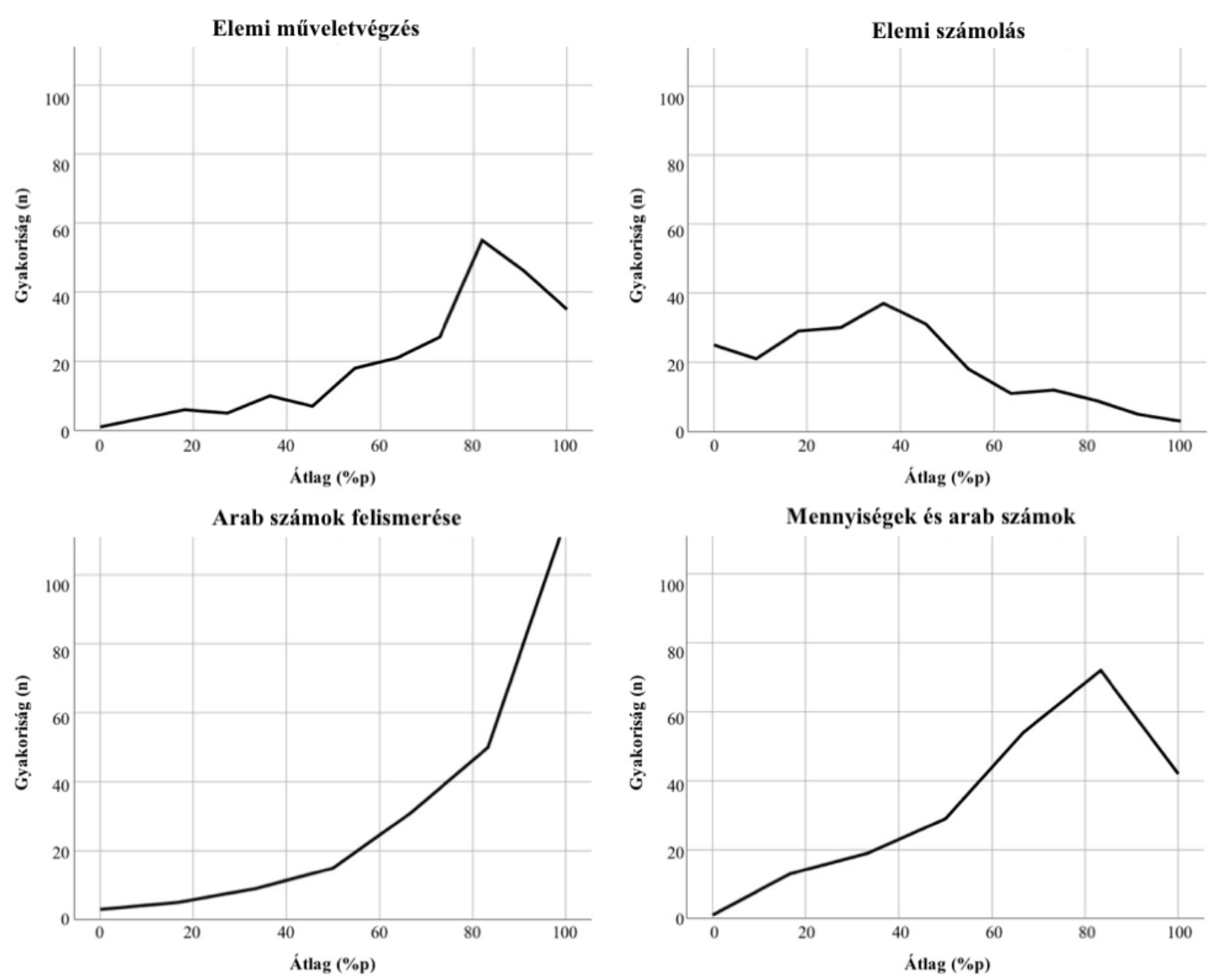

54. ábra

Átlagteljesitmények eloszlása a korai numerikus készségek teszt résztesztjein az óvodában (2. tesztváltozat)

Tesztelés ideje és eszközhasználat

A teszt kitöltésének időtartamát is ellenőriztük. Az óvodások átlagosan 19,2 perc alatt végeztek a korai numerikus készségek teszt feladataival, a tesztelés időtartamának szórása 7 perc volt. A rövidebb teszt magával hozta így a tesztelés átlagos időtartamának csökkenését is.

26. táblázat. A teszt és résztesztjeinek eloszlásmutatói óvodában (2. tesztváltozat)

\begin{tabular}{lcccc}
\hline \multicolumn{1}{c}{ Retested } & Ferdeség & Lapultság & $\begin{array}{c}\text { Kolmogorov- } \\
\text { Smirnov teszt }\end{array}$ & $\mathrm{p}<$ \\
\hline Elemi müveletvégzés & $-1,08$ & 0,69 & 0,21 & 0,001 \\
Elemi számolás & 0,48 & $-0,35$ & 0,11 & 0,001 \\
Arab számok felsimerése & $-0,72$ & $-0,16$ & 0,21 & 0,001 \\
Arab számok és mennyiségek & $-1,52$ & 1,92 & 0,28 & 0,001 \\
\hline Korai numerikus készségek teszt & $-0,27$ & $-0,25$ & 0,07 & 0,008 \\
\hline
\end{tabular}

Megjegyzés. Ferdeség (szimmetria) $=$ Skewness; Lapultság = Kurtosis; $\mathrm{p}=$ szignifikanciaszint. 
Az óvodás korú gyerekek 95,1 \%p-os teljesítményt nyújtottak a tablet eszközhasználat teszten, teljesítményük szórása 7,5\%p volt. Összeségében a vizsgált gyermekek számára nem jelentett problémát a tableten keresztül történő tesztelés, a különböző feladatmegoldási, válaszadási lehetőségekkel egyformán boldogultak. Ennél a feladatsornál is megfigyelhető a tanulási folyamat, amelyet az eszközhasználat teszt bövítése is eredményezett, mivel ezen az óvodai merésen már teljesen külön álló mérési alkalom és 28 feladat volt a tablet eszközhasználat felmérésnek és begyakorlásának szentelve. A plafoneffektus ellenére szignifikáns korrelációt találtunk az eszközhasználat és a korai numerikus készségek teszt eredménye között $(\mathrm{r}=0,32 ; \mathrm{p}<0,01)$. A gyermekek elhelyezkedését a két teszten elért teljesítmény függvényében az 55. ábrán mutatjuk.

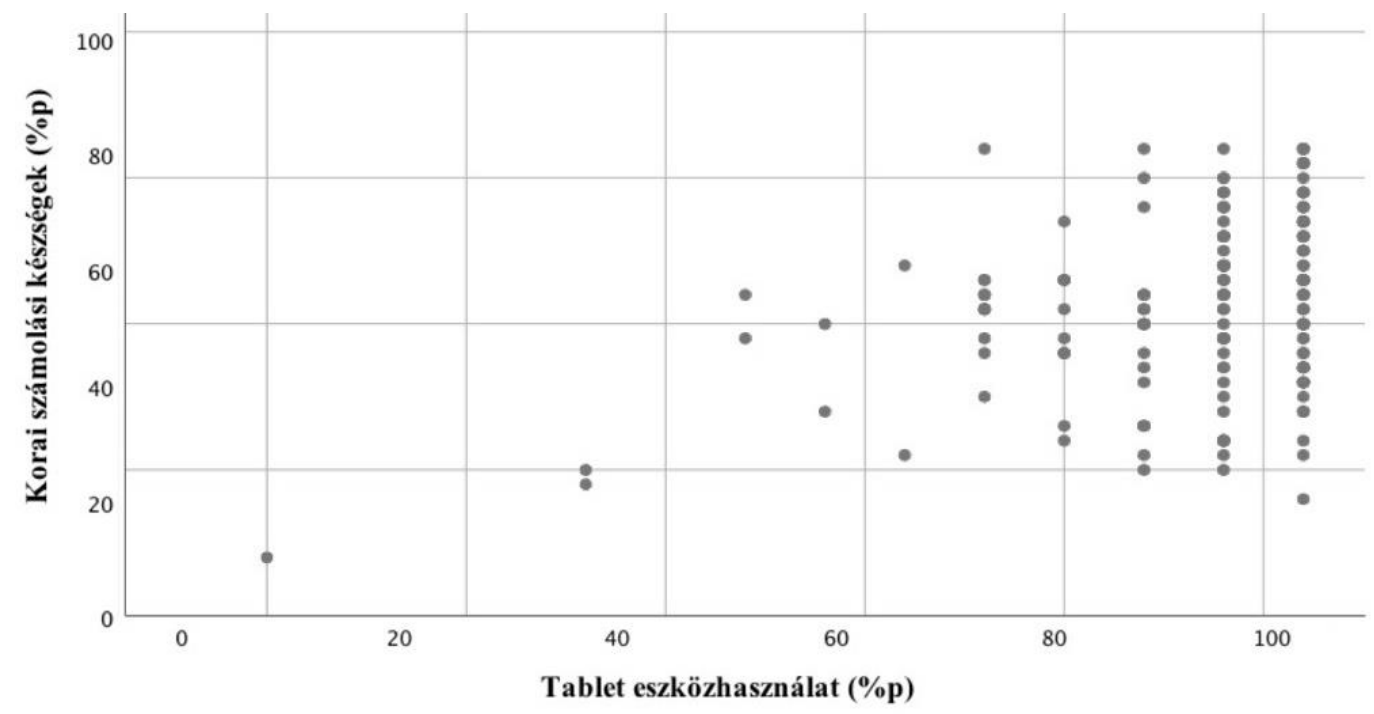

55. ábra

Az elsö évfolyamos tanulók a korai numerikus készségek és a számitógépes-egér használat teszteken elért teljesitménye

\subsection{Az óvodai validációs vizsgálat eredményei}

Az eddig bemutatott vizsgálatok eredményei alapján részletesen fel tudtuk tárni a korai numerikus készségeket vizsgált online teszt megbízhatóságát, konstruktum-validitását, itemeinek müködését, azonban továbbra is kevés információval rendelkezünk ahhoz, hogy kiderítsük mennyiben lehet képes kiváltani a szemtől szembeni vizsgálati eljárásokat, valamint egyes készségek online tesztelési megoldásai helyettesíthetik-e a gyermekek szóbeli válaszait, hangos számolását. Ennek érdekében egy kismintás óvodai vizsgálatot végeztünk, amelyben 
két online teszt, a korai numerikus készségek és a tablet eszközhasználat (Molnár \& Pásztor, 2015) mellett, a szemtől szembeni adatfelvételhez kötött DIFER elemi számolási készség és relációszókincs tesztjeit (Nagy et al., 2004b) is felvettük 30 óvodás gyermekkel. A vizsgálat mintáját, eszközeit és eljárásait részletesen ismertettük a módszereink között.

27. táblázat. Az óvodai validációs mérésen alkalmazott online mérőeszközök eredményei

\begin{tabular}{lcccc}
\hline \multicolumn{1}{c}{ Résztesztek } & $\begin{array}{r}\text { Itemek } \\
\text { száma }\end{array}$ & $\begin{array}{c}\text { Megbízhatóság } \\
(\text { Cronbach- } \alpha)\end{array}$ & Átlag (\%p) & Szórás (\%p) \\
\hline Elemi mủveletvégzés & 11 & 0,75 & 74,9 & 20,2 \\
Elemi számolás & 11 & 0,75 & 31,8 & 24.3 \\
Arab számok felsimerése & 6 & 0,66 & 60,0 & 27,2 \\
Arab számok és mennyiségek & 6 & 0,77 & 77,2 & 28,2 \\
\hline Korai numerikus készségek & 34 & 0,88 & 58,7 & 19,2 \\
\hline Tablet eszközhasználat & 16 & 0,40 & 91,5 & 7,6 \\
\hline
\end{tabular}

Óvodai vizsgálatunk eredményeinek ismertetését az online és a szemtől szembeni mérések megbízhatóságának és a gyermekek teszten elért átlagos teljesítményének ismertetésével kezdjük (27. és 28. táblázat). Mint azt módszereik között már ismertettük, ezen a mérésen a tablet eszközhasználat teszt reliabilitása különösen alacsony volt (Cronbach- $\alpha$ =0,40), melynek hátterében annak több speciális jellemzője állhat. Egyfelől a teszt közbeni tanulás lehetősége, valamint a plafoneffektus és az alacsony szórás. A gyermekek a feladatok sikertelen megoldása esetén újra próbálkozhattak, és a feladatsor közben egyre gyorsabban és pontosabban oldották meg tesztben szereplő vonszolási és érintéses feladatokat. A korai numerikus készségek teszt és résztesztjeinek reliabilitását a 26. táblázatban ismertetjük. A táblázatban nem szerepel a reláció részteszt, amelynek teljes, 6 feladatból álló résztesztjét kivettük az elemzésinkből. Az óvodai mérésen a részteszt reliabilitása az elfogadható érték alatt volt (Cronbach- $\alpha<0,3)$, itemeinek elkülönítésmutatói -0,13 és 0,41 között voltak. A teljes teszt reliabilitás mutatója így 0,873-ról 0,883-ra emelkedett. És ennek megfelelően a korai numerikus készségek teszt eredményét is 34 item alapján számítottuk ki. A másik négy részteszt megbízható volt, közülük az arab számok felismerése részteszté volt alacsonyabb. 
$x x x x x x x x x x x x x x x \mid$

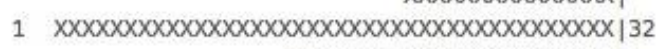
$x x x x x x x x x x x x x x x x x x x x x x x \mid$ $x x x x x x x x x x x x x x x x x x x x \mid 13$ $x x x x x x x x x x x x x x x x x x x x x x x x x x \mid$ $x \times x \times x \times x \times x \times \mid 5 \quad 17 \quad 34$ $x \times x x x x x x x x x x x \mid 27$

0 $x x x x x x x x x x x x x x x x x x x x \mid 31$ $X X X X X X X X \mid 40$ $x x x x x x x x x x \mid 37$ $x \times x x x x x x x x \mid$ $\begin{array}{llll}X X X X X X X X \mid 10 & 38 & 39\end{array}$ $x x x x x x x x x x x x x x x \mid 28$

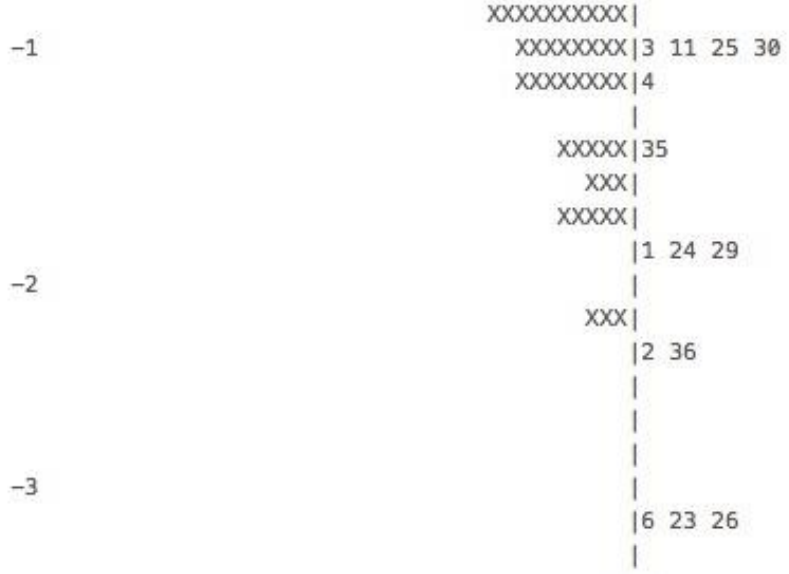
$x X X X X X X X \mid$ $x \times x X X X X X \mid 3 \quad 1125 \quad 30$ $x x x x x x x \mid 4$ $x \times x x x \mid 35$

56. ábra

A korai numerikus készségek teszt személy-item térképe az óvodai validációs mérésen. Bal oldalon a feladatok nehézsége és a tanulók képességszintje látható. Minden X 0,1 tanulót reprezentál. A jobb oldalon az itemek sorszáma szerepel.

A mérésben résztvevő óvodások korai numerikus készségek teszten elért átlagos teljesítménye $58,7 \%$ p volt. A résztesztek közül az új elemi számolási feladatok bizonyultak nehezebbnek, ezen a részteszten mindössze $31,8 \%$ p volt az áltagteljesítmény, a részteszt eloszlása is erőteljesen balra tolódik. Bár a Kolmogorov-Smirnov próba alapján a teljes teszt eloszlása megegyezett a normál eloszlással $\left(\chi^{2}=0,14 ; \mathrm{p}=0,13\right)$, a próba eredménye mind a négy résztesztnél szignifikáns eltérést mutatott a normál eloszlástól $\left(\chi^{2}=0,21-0,25 ; p<0,05\right)$. 
Egy paraméteres Rasch-elemzést végeztünk, hogy a korai numerikus készségek teszt itemeinek müködését is ellenőrizzük a kismintás óvoda mérésünknél. Az elemzés személy szeparációs reliabilitása a 30 fős mintánál is magas volt $(0,965)$. A teszt EAP/PV reliabilitása 0.893, ami szintén megfelelő értéknek tekinthető. Az 56. ábrán is látható, hogy a tesztfeladatok nagyjából egyenletesen fedik le a gyermekek képességszintjeit, ugyanakkor több item, amelyek a legalacsonyabb (-2 és -3) képességszinteken helyezkednek el, a vizsgált csoportban túl könnyüek voltak. Kivehető, hogy a 1-es képességszinten lévő feladatok köre viszont nem arányul az ezen a szinten elhelyezkedő gyermekek számához.

A 28. táblázatban foglaltuk össze a DIFER elemi számolási készség teszt és résztesztjeinek, valamint a relációszókincs teszt megbízhatóságát és az óvodás gyermekek átlagos teljesítményét. Az elemi számolási készség teszt (Cronbach- $\alpha=0,80$ ) és annak résztesztjei is megbízhatónak bizonyultak, egyedül a számlálás részteszt reliabilitása volt alacsonyabb (Cronbach- $\alpha=0,62$ ), de még elfogadható szinten belül. A megbízhatóság vizsgálat során ellenőriztük ennek a résztesztnek az előrefelé és a visszafelé számolás szerinti két skálára bontását is, azonban akkor még alacsonyabb, 0,5 alatti, reliabilitás mutatókat kaptunk volna. Ahogyan azt a módszerek között már ismertettük, a DIFER relációsszókincs teszt eredményét, 24 helyett, 22 item alapján számítottuk ki, két itemet azok alacsony elkülönítésmutatója miatt nem vontunk be az elemzéseinkbe.

28. táblázat. Az óvodai validációs mérésen alkalmazott szemtől szembeni méröeszközök eredményei

\begin{tabular}{lcccc}
\hline \multicolumn{1}{c}{ DIFER tesztek és résztesztek } & $\begin{array}{c}\text { Itemek } \\
\text { száma }\end{array}$ & $\begin{array}{c}\text { Megbízhatóság } \\
(\text { Cronbach- } \alpha)\end{array}$ & Átlag $(\% \mathrm{p})$ & Szórás (\%p) \\
\hline Számlálás & 14 & 0,63 & 68,9 & 22,1 \\
Manipulatív számolás & 11 & 0,80 & 64,5 & 21,4 \\
Számkép felismerés & 9 & 0,83 & 78,1 & 25,2 \\
Számolvasás & 4 & 0,71 & 47,2 & 30,2 \\
\hline Elemi számolási készség & 38 & 0,80 & 68,0 & 19,2 \\
\hline Relációszókincs & 22 & 0,62 & 80,5 & 12,3 \\
\hline
\end{tabular}

A DIFER elemi számolási készség teszten 68,0 \%p-os teljesítményt értek el a gyermekek, a legmagasabb teljesítmény a számkép felismerés résztesztjén volt tapasztalható (78,1\%p), míg a számolvasás részteszten mindössze 47,2 \%p-os átlagteljesítményt mértünk, amelynek szórása is magasabb volt többi részteszthez képest. A relációsszókincs teszten $80,5 \%$ p volt az átlagteljesítmény, és a teszt szórása is alacsony volt (12,3\%p). 
A mérésen alkalmazott online és szemtől szembeni eszközök korrelációit a 29 táblázatban foglaltuk össze. Elemzéseink alapján az online és a szemtől szembeni eszközök eredményei összefüggenek egymással, a vizsgált konstruktumok közül a két számolási készséget vizsgáló teszt között van a legerősebb kapcsolat. A korai numerikus készségek teszt és a DIFER elemi számolási készség teszt között szignifikáns összefüggés mutatható ki $(\mathrm{r}=0,84$; $\mathrm{p}<0,01)$. A két teszt résztesztjeinek összefüggéseit a következő bekezdésben még részletesen is bemutatjuk. A relációszókincs és a korai numerikus készégek teszt, valamint annak összes résztesztje között szignifikáns korrelációt találtunk. Továbbá a relációszókincs szignifikánsan összefügg a tablet eszközhasználat teszttel is $(r=0,48 ; p<0,01)$. A két szemtől szembeni DIFER teszt, az elemi számolási készség és a relációszókincs kapcsolatban állnak ( $\mathrm{r}=0,46 ; \mathrm{p}<0,01)$.

29. táblázat. Az online és a szemtöl szembeni méröeszközök összefüggései

\begin{tabular}{|c|c|c|c|c|c|c|c|}
\hline Mérőeszközök & 1 & 2 & $2 \mathrm{a}$ & $2 b$ & $2 \mathrm{c}$ & $2 d$ & 3 \\
\hline 1 - Tablet eszközhasználat & - & & & & & & \\
\hline 2 - Korai numerikus készségek & $0,47^{* *}$ & - & & & & & \\
\hline 2a - Elemi műveletvégzés & $0,48^{* *}$ & $0,82^{* *}$ & - & & & & \\
\hline 2b - Elemi számolás & 0,32 & $0,79^{* *}$ & $0,46^{*}$ & - & & & \\
\hline 2c - Arab számok felismerése & $0,51^{* *}$ & $0,80^{* *}$ & $0,65^{* *}$ & $0,45^{*}$ & - & & \\
\hline $2 \mathrm{~d}$ - Arab számok és mennyiségek & 0,18 & $0,75^{* *}$ & $0,49^{* *}$ & $0,45^{*}$ & $0,57^{* *}$ & - & \\
\hline 3 - D. Elemi számolási készség & 0,34 & $0,84^{* *}$ & $0,63^{* *}$ & $0,49^{* *}$ & $0,81^{* *}$ & $0,84^{* *}$ & - \\
\hline 4 - D. Relációszókincs & $0,48^{* *}$ & $0,60^{* *}$ & $0,45^{*}$ & $0,51^{* *}$ & $0,39^{*}$ & $0,51^{* *}$ & $0,46^{*}$ \\
\hline
\end{tabular}

Megjegyzés. $*=\mathrm{p}<0,05 ; * *=\mathrm{p}<0,01 ; \mathrm{D} .=$ DIFER

Az online korai numerikus készségek teszt és a szemtől szembeni DIFER elemi számolási készség teszt résztesztjei közötti összefüggéseket a 30. táblázatban foglaltuk össze. Az összefüggés-vizsgálatoknak köszönhetően ellenőrizhető, hogy az elméletileg ugyanarra a konstruktumra vonatkozó feladatsorok milyen szorosan függenek össze az önállóan, online formában és a mérőbiztos által, szóbeli kikérdezéssel felmérve. A résztesztek közötti kapcsolatot egyesével vizsgálva látható, hogy a legtöbb részteszt között szignifikáns kapcsolat áll fenn. 
30. táblázat. A DIFER elemi számolási készség teszt és korai numerikus készségek teszt résztesztjeinek összefüggései

\begin{tabular}{|c|c|c|c|c|c|c|c|}
\hline Mérőeszközök & $1 \mathrm{a}$ & $1 b$ & $1 \mathrm{c}$ & $1 d$ & $2 a$ & $2 b$ & $2 c$ \\
\hline 1a - D Számlálás & - & & & & & & \\
\hline 1b - D Manipulatív számolás & $0,49^{* *}$ & - & & & & & \\
\hline 1c - D Számkép felismerés & 0,35 & $0,56^{* *}$ & - & & & & \\
\hline 1d - D Számolvasás & $0,79^{* *}$ & $0,63^{* *}$ & $0,42^{*}$ & - & & & \\
\hline 2a - K Elemi müveletvégzés & $0,68^{* *}$ & 0,33 & 0,23 & $0,53^{* *}$ & - & & \\
\hline 2b - K Elemi számolás & $0,49^{* *}$ & $0,47^{* *}$ & 0,04 & $0,49^{* *}$ & $0,46^{*}$ & - & \\
\hline 2c - K Arab számok felismerése & $0,76^{* *}$ & $0,60^{* *}$ & $0,44^{*}$ & $0,76^{* *}$ & $0,65^{* *}$ & $0,45^{*}$ & - \\
\hline 2d - K Arab számok és mennyiségek & $0,78^{* *}$ & $0,64^{* *}$ & $0,48^{* *}$ & $0,67^{* *}$ & $0,49^{* *}$ & $0,45^{*}$ & $0,57^{* *}$ \\
\hline
\end{tabular}

Megjegyzés. $*=\mathrm{p}<0,05 ; * *=\mathrm{p}<0,01 ; \mathrm{D}=\mathrm{DIFER}$ elemi számolási készség teszt; $\mathrm{K}=$ Korai numerikus készségek teszt (online).

A DIFER számlálás résztesztje és az online elemi számolás résztesztek között közepes mértékü kapcsolatot találtunk $(r=0,49 ; \mathrm{p}<0,01)$, valamint a DIFER számolvasás és az online formában mért arab számok felismerése között is szignifikáns korrelációt találtunk $(r=0,76 ; p<0,01)$. Az egyedül a korai numerikus készségek tesztben szereplő arab számok és mennyiségek kapcsolatát mérő részteszt a DIFER mindegyik résztesztjével szignifikánsan összefüggött, ahogyan az arab számok felismerése és minden szemtől szembeni részteszt között is kapcsolatot találtunk. Ugyanakkor az online formában vizsgált elemi műveletvégzés részteszt, amelyben a megszámlálás, kiegészítés, bontás feladatai ugyanúgy megjelentek, nem korrelált a DIFER-es manipulatív számolás részteszthez, és a számkép felismeréshez sem, amelyben szintén jelennek meg összeadási műveletek.

A kisgyermekek tablet eszközhasználatának felmérése szerint a gyermekeknek nem volt gondjuk az online tesztek feladatainak megoldásával. Átlagosan 91,5\%p-ot értek el, alacsony szórás mellett $(7,2 \%$ p), a legalacsonyabb teljesítmény $75 \%$ p volt. Emellett, a korábbi méréseinkhez hasonlóan, itt is találtunk összefüggést az eszközhasználat és a másik terület teszteredményei között. A tablet eszközhasználat teszt és a korai numerikus készségek teszt résztesztjeinek összefüggését megvizsgálva az elemi számolás résztesztnél nem találtunk szignifikáns korrelációt ( $\mathrm{r}=0,32 ; \mathrm{p}=0,09)$, ahogyan a arab számok és mennyiségek résztesztnél sem $(\mathrm{r}=0,18 ; \mathrm{p}=0,35)$, miközben a többi, kevésbé összetett feladatmegoldást igénylő résztesztnél, az elemi műveletvégzés $(\mathrm{r}=0,48 ; \mathrm{p}<0,05)$, valamint az arab számok felismerése $(\mathrm{r}=0,51 ; \mathrm{p}<0,05)$ esetében is szignifikánsak voltak az összefüggések. Ugyanakkor az 
eszközhasználat teszt 0,48 -as erősségü, szignifikáns összefüggést mutatott a DIFER relációsszókincs tesztjével is.

A két online teszt felvételének ideje összesen átlagosan 30 percet vett igénybe, melyböl a tablet eszközhasználat teszten 9,1 percet, a korai numerikus készségek teszten pedig további 21,5 percet töltöttek átlagosan a mérésben résztvevő kisgyermekek.

A 3. óvodai vizsgálat online tesztjeinek felvételekor kvantitatív módszereinket részben kiegészítettük videómegfigyeléssel is. A mérésben résztvevő gyermekek 4-5 fős csoportjaiból véletlenszerüen egy-egy gyermeket választottunk ki, akiknél a tablet képernyőjét is rögzítve vettük fel a két online teszt kitöltését. Ilyen formában összesen 3 gyermek online tesztfelvételét sikerült rögzítenünk és elemzünk ki. A videók feldolgozásához szempontsort állítottunk össze, amely a gyermekek figyelmének és a feladatok megoldásának elemzésére szolgált. A három gyermekből kettő esetében figyeltük meg, hogy a tesztelés elkezdését követő 5-7 perc múlva elkezdtek a közelükben helyet foglaló társaik feladatai felől érdeklődni, és saját feladatukból időnként felnézve ellenőrizték társaik előrehaladását. Emellett mindhárom gyermek tesztelése során előfordult, hogy a következő feladatra lépve azok többször csak pár másodperces késéssel töltődtek be. Hosszabb, 5 másodperc feletti várakozás esetén a gyermekek ilyenkor rendszerint egyből a teremben lévő felnőtt tekintetét keresték. A harmadik gyermek végig a saját feladataira koncentrált, a nagyjából egy méterre ülő társának képernyőjére nem tekintett rá.

Megfigyeléseink alapján a vonszolással megoldható feladatok könnyebbek voltak a gyermekek számára, ugyanakkor a tablet eszközhasználat teszt elején még előfordult két gyermeknél is, hogy egy-egy feladat megoldása, a rajz a kért célterületre húzása, csak sokadszorra sikerült. A tesztben eltöltött első perceket egyértelmüen gyakorlással töltötték. Emellett kisebb fennakadást jelentett, hogy a feladatokat a válaszadást követően a képernyő jobb alsó sarkában lévő nyílra kattintva lehetett tovább léptetni. Bár ez a teszt eleji instrukcióban nyomatékosan szerepelt, és ott tovább is tudtak lépni, a helyes megoldást követően előfordult, hogy még másodpercekig várakoztak, amíg tovább nem léptek a következő feladatra. Az egyik gyermek esetében a mérőbiztosnak az első feladatoknál újra meg kellett mutatni, hogyan lehetséges tovább lépni a tesztben. Emellett a számítógépes feladatsorban kattintással, tableteken érintéssel kivitelezhető válaszadás, mindhárom megfigyelt gyermek esetében csak többszöri próbálkozásra sikerült. A tablet eszközhasználat feladatain gyakorolták be a megfelelő érintési technikát, azonban véletlenszerüen a későbbi számolási feladatokban is előfordult, hogy nem sikerült elsőre a helyes válaszra kattintani. A videókból kiderült, hogy a gyermek pontosságával nem volt probléma, az ujjával lendületesen a megfelelő pontra mutatott, az érintőképernyő viszont mégsem érzékelte azt, mivel vagy túl hosszan, vagy túl rövid 
időtartamig ért hozzá. A videón megfigyelhető volt, ahogyan a feladatokban előre haladva, egyre kevésbé kell újra próbálkoznia. Az első tablet eszközhasználatos feladatoknál azt is tapasztaltuk, hogy az érintéskor elhelyezett piros pöttyre, ha az értintéshez képest késve tünt fel, ismételten rámutatva azt véletlenül törölték is, azonban ezt minden esetben észlelték és javították.

\subsection{A korai numerikus készségek fejlődése}

Az óvodai és az iskolai mérés eredményeinek összehasonlitása

Bár korábban már szerepeltek mindkét mérés pszichometriai jellemzői, ezek közül ismét közöljük a reliabilitás-mutatókat kizárólag azokra az itemekre kiszámítva, amelyek az óvodás és az iskolás mérésben egyaránt szerepeltek. A korábban bemutatott értékekhez képest az óvodai mérésnél a relációk részteszt, az iskolai mérésnél pedig az elemi számolás részteszt reliabilitása csökkent. A relációk esetében 5 itemmel kevesebb szerepelt az iskolai mérésen, az elemi számolás esetében pedig jobb összehasonlíthatóság érdekében visszaemeltünk korábban az elkülönítésmutatók alapján kivett itemeket. Az elemi számolás részteszt ezen itemei megfelelően működtek az óvodában, és míg az iskolai mérés reliabilitását mindössze két századdal rontották, kivételük öt századdal csökkentette volna az óvodai mérés elemi számolás résztesztjének megbízhatóságát, valamint érintette volna a teljes teszt reliabilitását is. Raschelemzéssel is ellenőrizve a teszt első változatának müködését az összes kitöltő együttes eredményei alapján, a korai numerikus készségek teszt EAP/PV reliabilitása 0,88.

31. táblázat. A korai numerikus készségek teszt és résztesztjeinek megbizhatósága az óvodában és az iskolában (1. tesztváltozat)

\begin{tabular}{lccc}
\hline \multicolumn{1}{c}{ Résztesztek } & Itemek száma & $\begin{array}{c}\text { Óvoda } \\
\text { Megbízhatóság } \\
\text { (Cronbach- } \alpha)\end{array}$ & $\begin{array}{c}\text { Iskola } \\
\text { Megbízhatóság } \\
(\text { Cronbach- } \alpha)\end{array}$ \\
\hline Mennyiségek és számok & 6 & 0,87 & 0,75 \\
Elemi számolás & 8 & 0,70 & 0,57 \\
Relációk & 10 & 0,72 & 0,69 \\
Elemi műveletvégzés & 8 & 0,83 & 0,70 \\
Arab számok felismerése & 5 & 0,82 & 0,69 \\
Arab számok és mennyiségek & 8 & 0,88 & 0,71 \\
\hline Korai numerikus készségek teszt & 45 & 0,94 & 0,89 \\
\hline
\end{tabular}


A vizsgált óvodás korcsoport 5,8 éves, az első évfolyamos csoport átlagosan 7,1 éves volt a méréseink idején. A korai numerikus készségek teszten elért teljesítmény 21 százalékponttal volt magasabb az iskolások körében. Az összes részteszten elért teljesítmény 20-21\%p körül fejlődött. A mennyiségek és számok részteszten és az elemi számolás részteszten egyaránt 21,5 \%p-os növekedés tapasztalható, ahogyan az elemi müveletvégzésen 21,6 százalékponttal mértünk magasabb teljesítményt iskolában. Az iskola kezdőszakaszában előtérben lévő arab számokat tartalmazó feladatoknál vegyes kép rajzolódik ki, az 10-es számkörön belüli arab számok mennyiségekhez való kapcsolását mérő arab számok és mennyiségek részteszten a többi részteszthez képest alacsonyabb volt az emelkedés (18,7\%p), viszont a 100-as és 500-as számkörben arab számok tartalmazó, arab számok felismerése részteszten volt a legmagasabb növekedés, átlagosan 24,4\%p. Az átlagteljesítmények szórásai a két csoportban az összes résztesztnél eltértek, így különbözőség-vizsgálatok közül a Welch-próba eredményeit közöljük, amely minden esetben szignifikáns volt. A fejlődés mértékének standardizált mutatóval való kifejezéséhez hatásméretet számoltunk (Cohen-d), amelynek értéke az összes részteszt és a teljes teszt esetében is magas.

32. táblázat. A korai numerikus készségek teszten és résztesztjein elért eredmények az óvodában és elsö évfolyamon

\begin{tabular}{|c|c|c|c|c|c|c|c|}
\hline \multirow[b]{2}{*}{ Retested } & \multicolumn{2}{|c|}{ Óvoda } & \multicolumn{2}{|c|}{ Iskola } & \multirow[b]{2}{*}{ Cohen-d } & \multirow[b]{2}{*}{ d } & \multirow[b]{2}{*}{$\mathrm{p}<$} \\
\hline & $\begin{array}{l}\text { Átlag } \\
(\% \mathrm{p})\end{array}$ & $\begin{array}{c}\text { Szórás } \\
(\% \mathrm{p})\end{array}$ & $\begin{array}{l}\text { Átlag } \\
(\% \mathrm{p})\end{array}$ & $\begin{array}{c}\text { Szórás } \\
(\% \mathrm{p})\end{array}$ & & & \\
\hline Mennyiségek és számok & 63,5 & 36,8 & 85,1 & 23,5 & 0,70 & 10,7 & 0,001 \\
\hline Elemi számolás & 50,8 & 27,9 & 72,3 & 22,1 & 0,85 & 13,9 & 0,001 \\
\hline Relációk & 48,5 & 22,4 & 68,6 & 20,3 & 0,94 & 16,2 & 0,001 \\
\hline Elemi mủveletvégzés & 66,6 & 30,9 & 88,2 & 18,0 & 0,85 & 12,8 & 0,001 \\
\hline Arab számok felismerése & 60,1 & 36,2 & 84,5 & 23,4 & 0,80 & 12,3 & 0,001 \\
\hline Mennyiségek és arab számok & 70,4 & 33,0 & 89,1 & 17,5 & 0,71 & 10,3 & 0,001 \\
\hline $\begin{array}{l}\text { Korai numerikus készségek } \\
\text { teszt }\end{array}$ & 59,3 & 24,0 & 80,3 & 15,2 & 1,05 & 16,0 & 0,001 \\
\hline
\end{tabular}

Megjegyzés. Cohen- $\mathrm{d}=$ hatásméret; $\mathrm{d}=$ Welch-féle d-próba eredménye; $\mathrm{p}=$ szignifikanciaszint.

Az előző alfejezetekben külön-külön ismertettük az eloszlásokat az óvodai és az iskolai méréseken. $\mathrm{Az}$ 57. ábrán együtt látható a korai numerikus teszt első változatán elért teljesítmények relatív gyakorisági eloszlása az óvodában és az elős évfolyamon. A két eloszlás 
szignifikánsan eltér egymástól a teljes teszt $(Z=7,3 ; p<0,001)$, és az egyes résztesztek esetében is $(\mathrm{Z}=4,9-6,3 ; \mathrm{p}<0,001)$.

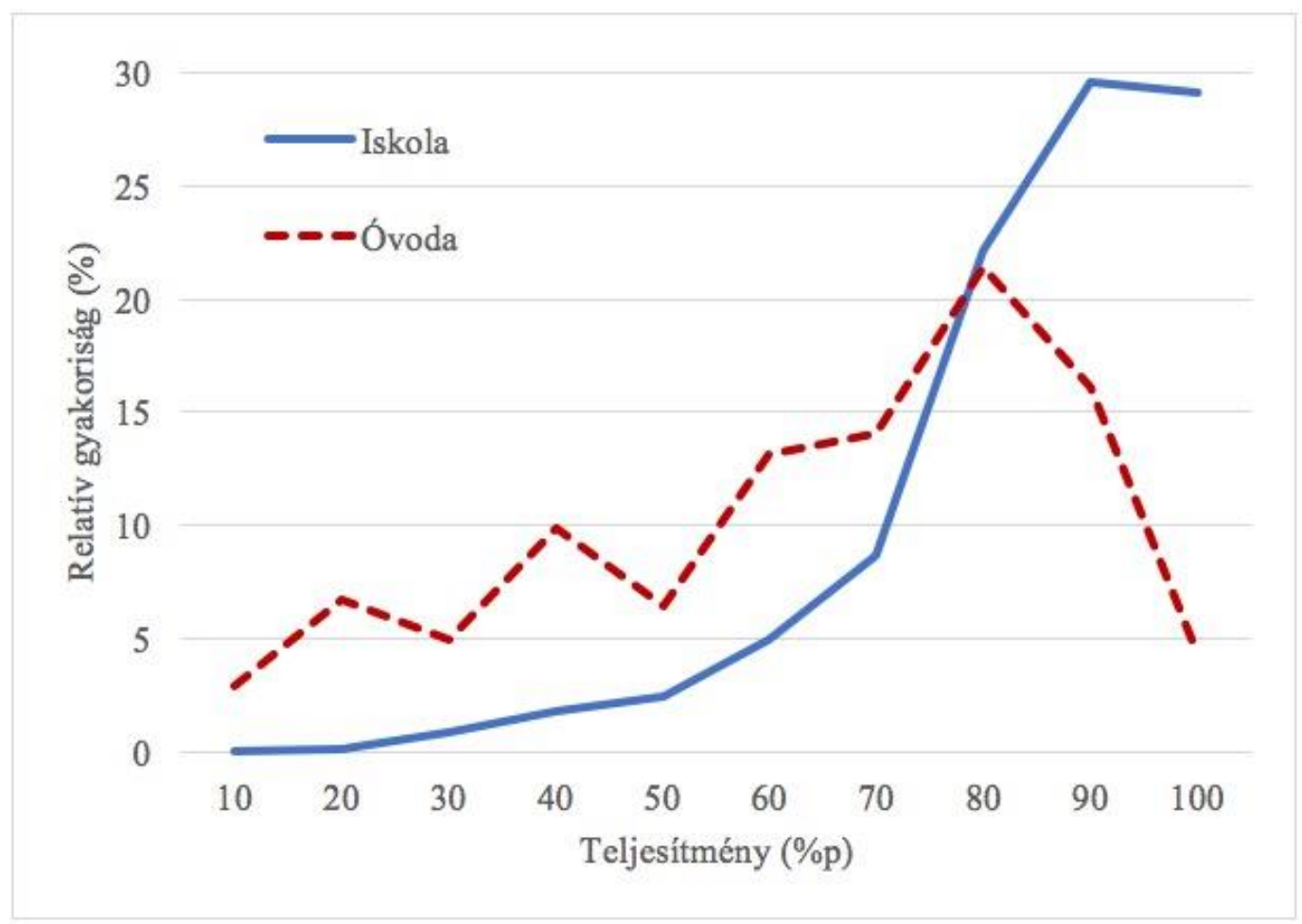

57. ábra

A korai numerikus készségek teszten elért teljesítmények eloszlása az óvodai és iskolai méréseken

\section{Nemek közötti különbségek az óvodában}

A három korai numerikus készségek teszttel végzett mérésnél megvizsgáltuk a nemek közötti különbségeket a teszten és részteszteken elért átlagteljesítmény tekintetében. Először a két óvodai mérésen feltárt eltéréseket közöljük, melyek közül az első az online tesztünk első 52 itemes tesztváltozatával készült, az elemzéseken a teszt pszichometriai jellemzésekor már ismertetett megbízhatóságot és érvényességet is növelő indokok miatt, 50 item eredményeit használtuk fel. A második tesztváltozat 40 itemet tartalmazott, amelyek mindegyike szerepel a jelenlegi elemzéseink során. 
33. táblázat. Nemek közötti különbségek a korai numerikus készségek teszten és résztesztjein az óvodában (1. tesztváltozat)

\begin{tabular}{|c|c|c|c|c|c|c|}
\hline \multirow[b]{2}{*}{ Résztesztek } & \multicolumn{2}{|c|}{ Fiúk } & \multicolumn{2}{|c|}{ Lányok } & \multirow[b]{2}{*}{$\mathrm{t} / \mathrm{d}$} & \multirow[b]{2}{*}{$\mathrm{p}$} \\
\hline & $\begin{array}{l}\text { Átlag } \\
(\% \mathrm{p})\end{array}$ & $\begin{array}{l}\text { Szórás } \\
(\% \mathrm{p})\end{array}$ & $\begin{array}{l}\text { Átlag } \\
(\% \mathrm{p})\end{array}$ & $\begin{array}{c}\text { Szórás } \\
(\% \text { p })\end{array}$ & & \\
\hline Mennyiségek és számok & 60,7 & 37,9 & 66,6 & 35,5 & 1,48 & 0,14 \\
\hline Elemi számolás & 49,2 & 27,3 & 49,5 & 24,9 & 0,08 & 0,94 \\
\hline Relációk & 44,2 & 21,8 & 45,7 & 21,2 & 0,66 & 0,51 \\
\hline Elemi műveletvégzés & 61,2 & 32,4 & 72,4 & 28,2 & 3,40 & 0,01 \\
\hline Arab számok felismerése & 59,7 & 37,9 & 60,4 & 34,5 & 0,21 & 0,83 \\
\hline Mennyiségek és arab számok & 70,0 & 34,0 & 70,7 & 32,1 & 0,19 & 0,85 \\
\hline $\begin{array}{l}\text { Korai numerikus készségek } \\
\text { teszt }\end{array}$ & 55,6 & 24,1 & 58,8 & 22,4 & 1,24 & 0,21 \\
\hline
\end{tabular}

Megjegyzés. $\mathrm{t}$ = t-próba eredménye; $\mathrm{d}=$ Welch-féle d-próba eredménye; $\mathrm{p}=$ szignifikanciaszint.

A mennyiségek és számok, az elemi müveletvégzés, valamint az arab számok felismerése részteszteken nem egyeztek meg vizsgált csoportok szórásai $(F=3,9-8,1 ; \mathrm{p}<0,05)$, így ott a különbözőségvizsgálathoz Welch-próbát végeztünk. Az elemi müveletvégzés részteszten a lányok szignifikánsan magasabb teljesítményt (72,4 \%p) értek el, mint a fiúk (61,2 \%p). Emellett a mennyiségek és számok résztesztnél vehető észre $6 \%$ p-os különbség a lányok javára, azonban az eltérés nem szignifikáns. A többi részteszt és a teljes teszt esetében sem találtunk további jelentős eltérést a nemek szerinti csoportok között.

34. táblázat. Nemek közötti különbségek a korai numerikus készségek teszten és résztesztjein az óvodában (2. tesztváltozat)

\begin{tabular}{|c|c|c|c|c|c|c|}
\hline \multirow[b]{2}{*}{ Résztesztek } & \multicolumn{2}{|c|}{ Fiúk } & \multicolumn{2}{|c|}{ Lányok } & \multirow[b]{2}{*}{$t / d$} & \multirow[b]{2}{*}{$\mathrm{p}$} \\
\hline & $\begin{array}{l}\text { Átlag } \\
(\% \mathrm{p})\end{array}$ & $\begin{array}{c}\text { Szórás } \\
(\% p)\end{array}$ & $\begin{array}{l}\text { Átlag } \\
(\% \text { p) }\end{array}$ & $\begin{array}{c}\text { Szórás } \\
(\% p)\end{array}$ & & \\
\hline Elemi műveletvégzés & 77,9 & 20,0 & 72,9 & 22,8 & 1,64 & 0,10 \\
\hline Elemi számolás & 35,5 & 22,4 & 37,1 & 26,9 & 0,47 & 0,64 \\
\hline Arab számok felismerése & 67,7 & 23,5 & 72,6 & 24,7 & 1,44 & 0,15 \\
\hline Mennyiségek és arab számok & 81,3 & 24,2 & 84,4 & 24,3 & 0,88 & 0,38 \\
\hline Korai numerikus készségek teszt & 63,2 & 16,2 & 63,3 & 17,9 & 0,05 & 0,96 \\
\hline
\end{tabular}

Megjegyzés. $\mathrm{t}$ = t-próba eredménye; $\mathrm{d}$ = Welch-féle d-próba eredménye; $\mathrm{p}=$ szignifikanciaszint.

A két nem teszteredményeinek további összehasonlításához összevetettük a két csoport teljesítményének eloszlásait is az összes résztesztre. Kolmogorov-Smirnov Z próbával 
részletesen ellenőrizve az eltéréseket, kizárólag az elemi müveletvégzésnél találtunk szignifikáns eltérést az óvodás fiúk és lányok átlageredményeinek eloszlása között $(Z=1,8$; $\mathrm{p}<0,01)$.

A második tesztváltozattal óvodában végzett mérésen a szórások az elemi számolás részteszt esetében nem egyeztek meg $(\mathrm{F}=4,2 ; \mathrm{p}<0,05)$, így a részteszt eredményeinek nemek közötti összehasonlításánál Welch-próbát alkalmaztunk. Bár láthatóak eltérések fiúk is lányok között az egyes részteszteken ezek egyike sem tekinthető szignifikánsnak, ahogyan nem találtunk különbséget a teljes teszten elért eredmények tekintetében sem.

Az átlagok szignifikáns eltérésének hiánya ellenére fontosnak tartottuk ellenőrizni, hogy a teszteredmények eloszlását összehasonlítva észlelhetö-e a két csoport között különbség. A Kolmogorov-Smirnov $\mathrm{Z}$ próba eredményei alapján elmondható, hogy egyetlen részteszt és a teljes teszt eloszlása esetében sem volt szignifikáns eltérés.

Nemek közötti különbségek az iskolában

35. táblázat. Nemek közötti különbségek a korai numerikus készségek teszten és résztesztjein az iskolában (1. tesztváltozat)

\begin{tabular}{lccccccc}
\hline \multirow{2}{*}{\multicolumn{1}{c}{ Résztesztek }} & \multicolumn{3}{c}{ Fiúk } & \multicolumn{2}{c}{ Lányok } & \multirow{2}{*}{ t/d } & $\mathrm{p}$ \\
\cline { 2 - 5 } & $\begin{array}{c}\text { Átlag } \\
(\% \mathrm{p})\end{array}$ & $\begin{array}{c}\text { Szórás } \\
(\% \mathrm{p})\end{array}$ & $\begin{array}{c}\text { Átlag } \\
(\% \mathrm{p})\end{array}$ & $\begin{array}{c}\text { Szórás } \\
(\% \mathrm{p})\end{array}$ & & \\
\hline Mennyiségek és számok & 84,3 & 24,1 & 86,4 & 22,4 & 3,22 & 0,001 \\
Elemi számolás & 73,9 & 26,4 & 71,8 & 26,4 & 2,90 & 0,004 \\
Relációk & 62,9 & 24,4 & 63,5 & 22,7 & 0,99 & 0,322 \\
Elemi müveletvégzés & 87,1 & 18,8 & 89,6 & 16,8 & 3,40 & 0,001 \\
Arab számok felismerés & 85,5 & 23,0 & 84,0 & 23,1 & 2,43 & 0,015 \\
Mennyiségek és arab számok & 89,3 & 17,3 & 89,1 & 17,5 & 0,41 & 0,678 \\
\hline Korai numerikus készségek & 80,4 & 16,0 & 80,9 & 15,0 & 1,03 & 0,302 \\
teszt & & & & &
\end{tabular}

Megjegyzés. $\mathrm{t}$ = t-próba eredménye; $\mathrm{d}=$ Welch-féle d-próba eredménye; $\mathrm{p}=$ szignifikanciaszint.

Az iskolai mérésen a szórások az elemi műveletvégzés $(\mathrm{F}=26,1 ; \mathrm{p}<0,01)$, a relációk $(\mathrm{F}=11,2 ; \mathrm{p}<0,01)$ résztesztek és teljes teszt esetében $(\mathrm{F}=13,9 ; \mathrm{p}<0,01)$ sem egyeztek meg a szórások, így az eredmények nemek közötti összehasonlításánál a Welch-próba értékét használtuk fel. Az iskolai mérésnél a teljes teszt tekintetében nem, annak egyes résztesztjeink viszont találtunk kimutatható különbséget a fiúk és a lányok átlagteljesítménye között. A első 
osztályos lányok teljesítettek jobban a mennyiségek és számok, elemi müveletvégzés résztesztjein, a fiúk pedig az elemi számolás, arab számok felismerése feladatsorain nyújtottak jobb teljesítményt. A különbség mindegyik esetben szignifikáns, de csak 1,5-2 \%p körüli. Az első tesztváltozaton óvodában a lányok épp ezeken a részteszteken értek el magasabb teljesítményt.

A két csoport átlagteljesítményeinek eloszlásának vizsgálatához Kolmogorov-Smirnov $Z$ próbát végeztünk, amely alapján az látható, hogy a mennyiségek és számok $(Z=1,6 ; p=0,02)$, elemi számolás $(Z=1,5 ; p=0,02)$, elemi müveletvégzés $(Z=21,2 ; p<0,01)$ és arab számok felismerése $(Z=1,8 ; p<0,01)$ részteszteken is eltért a fiúk és a lányok teljesítményének eloszlása, ugyanakkor a teljes teszten elért teljesítmény esetében nem találtunk szignifikáns különbséget $(Z=1,1 ; \quad p=0,18)$. Összességében, az eloszlásvizsgálat eredményei leképezték a különbözőségvizsgálatnál is azonosított eltéréseket.

\subsection{A korai numerikus készségek és az első évfolyam végi matematika teljesítmény}

A következőkben az első évfolyamos tanulók körében végzett longitudinális vizsgálatunk eredményeit ismertetjük, amelynél az első évfolyamos tanulók iskolai bemeneti méréseket követően a tanév végén is részt vettek egy vizsgálatban. Longitudinális elemzéseinket a korai numerikus készségek teszt első változatával végeztük, amelynek fő eredményeit röviden újra közöljük (37. táblázat) a következő longitudinális elemzések mintájára leszükítve (N=4277). A korai numerikus készségek teszt további pszichometriai jellemzőit, megbízhatóságát, konstruktum-validitását a 8.2. alfejezetben mutattuk be. Az első évfolyam végén felvett matematika teljesítmény teszt tartalmi kereteit módszereink leírásakor részletesen ismertettük. A tanulók matematika teszten és résztesztjein elért átlagos teljesítményét a 36 . táblázatban foglaltuk össze.

36. táblázat. A matematika teszt és résztesztjeinek megbizhatósága és a tanulók átlagteljesitménye

\begin{tabular}{lcccc}
\hline \multicolumn{1}{c}{ A matematika teszt dimenziói } & Itemek száma & $\begin{array}{c}\text { Megbízhatóság } \\
(\text { Cronbach- } \alpha)\end{array}$ & $\begin{array}{c}\text { Átlag } \\
(\% \mathrm{p})\end{array}$ & $\begin{array}{c}\text { Szórás } \\
(\% \mathrm{p})\end{array}$ \\
\hline Gondolkodás & 12 & 0,83 & 43,0 & 25,3 \\
Alkalmazás & 19 & 0,87 & 54,3 & 25,3 \\
Tantárgyi & 19 & 0,88 & 54,2 & 27,8 \\
\hline Teljes matematika teszt & 50 & 0,94 & 50,0 & 22,8 \\
\hline
\end{tabular}


37. táblázat. A korai numerikus készségek teszt és résztesztjeinek megbizhatósága és a tanulók átlagteljesítménye

\begin{tabular}{lcccc}
\hline \multicolumn{1}{c}{ Részteszt elnevezése } & Itemek száma & $\begin{array}{c}\text { Megbízhatóság } \\
(\text { Cronbach- } \alpha)\end{array}$ & $\begin{array}{c}\text { Átlag } \\
(\% \mathrm{p})\end{array}$ & $\begin{array}{c}\text { Szórás } \\
(\% \mathrm{p})\end{array}$ \\
\hline Mennyiségek és számok & 6 & 0,74 & 85,5 & 22,9 \\
Elemi számolás & 5 & 0,59 & 72,6 & 22,3 \\
Relációk & 8 & 0,68 & 86,4 & 25,1 \\
Elemi múveletvégzés & 8 & 0,69 & 88,7 & 17,5 \\
Arab számok felismerése & 5 & 0,69 & 84,8 & 23,4 \\
Arab számok és mennyiségek & 8 & 0,70 & 89,4 & 17,2 \\
\hline Korai numerikus készségek teszt & 40 & 0,89 & 82,6 & 15,5 \\
\hline
\end{tabular}

Az első évfolyam végi matematika a tanulók teszten elért átlagos teljesítménye kereken $50 \%$ p volt, a részesztek eredményei is hasonlóan alakultak a gondolkodás részteszt bizonyult nehezebbnek, itt $43 \%$ p-os átlagot értek el az elsősök. A másik két részteszten egyformán 54$54 \%$ p volt az áltagteljesítmény. A teljes teszten és a részteszteken elért teljesítmény eloszlása nem egyezett meg a normál eloszlással a Kolmogorov-Smirnov próba eredménye szerint.

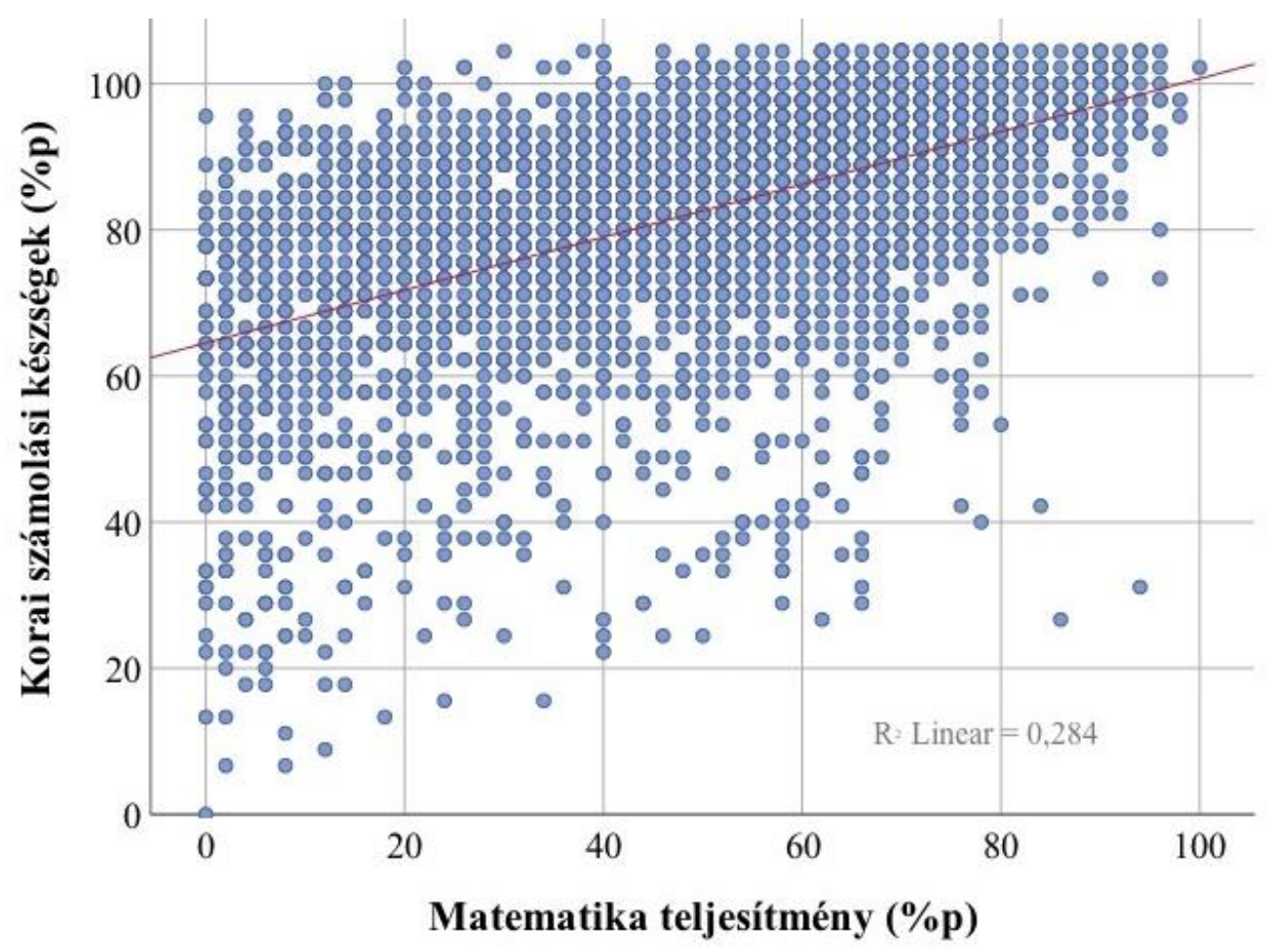

58. ábra

Tanulói átlagteljesitmények összefüggése

a korai numerikus készségek teszten és a matematika teszten 
Részletesen elemeztük a korai matematikai készségek és az első év végi matematika teljesítmény összefüggését. A két teszteredmény között közepes erősségü, szignifikáns korrelációt találtunk $(\mathrm{r}=0,53 ; \mathrm{p}<0,001)$. Továbbá a korai matematikai készségek a lineáris regressziós elemzés eredménye szerint 28,4\%-ban magyarázzák az első év végi matematika teljesítményt (58. ábra).

A 38. táblázatban összefoglaltuk a korai numerikus készségek teszt résztesztjeinek és a matematika teszt három dimenziójának korrelációs együtthatóit, a táblázatban feltüntetett összefüggések mindegyike szignifikáns $(\mathrm{p}<0,001)$. A résztesztek korrelációit végig nézve az látjuk, hogy a matematika teszt három részénél a korai numerikus készségek teszt relációk, az elemi számolás és az arab számok felismerése résztesztjei magasabb korrelációs együtthatókkal rendelkeznek. Ezek közül a relációk részteszt értékei bizonyultak erősebbnek, amely a matematika tantárgyi dimenzióval van szorosabb kapcsolatban. Ugyanez figyelhető meg az elemi számolás résztesztjénél, és az arab számok felismerésénél is a matematika tantárgyai területtel volt magasabb a korreláció.

38. táblázat. A DIFER elemi számolási készség teszt és korai numerikus készségek teszt résztesztjeinek összefüggései

\begin{tabular}{lcccccccc}
\hline \multicolumn{1}{c}{ Mérőeszközök } & $1 \mathrm{a}$ & $1 \mathrm{~b}$ & $1 \mathrm{c}$ & $2 \mathrm{a}$ & $2 \mathrm{~b}$ & $2 \mathrm{c}$ & $2 \mathrm{~d}$ & 2e \\
\hline 1a - M Gondolkodás & - & & & & & & & \\
1b - M Alkalmazás & 0,62 & - & & & & & & \\
1c - M Tantárgyi & 0,64 & 0,71 & - & & & & & \\
2a - K Mennyiségek és számok & 0,26 & 0,27 & 0,27 & - & & & & \\
2b - K Elemi számolás & 0,33 & 0,33 & 0,38 & 0,38 & - & & & \\
2c - K Relációk & 0,41 & 0,44 & 0,49 & 0,44 & 0,51 & - & & \\
2d - K Elemi múveletvégzés & 0,28 & 0,30 & 0,31 & 0,45 & 0,37 & 0,48 & - & \\
2e - K Arab számok felismerése & 0,31 & 0,33 & 0,35 & 0,42 & 0,46 & 0,50 & 0,45 & - \\
2f - K Arab szám és mennyiség & 0,29 & 0,33 & 0,33 & 0,40 & 0,40 & 0,46 & 0,49 & 0,56 \\
\hline
\end{tabular}

Megjegyzés. $\mathrm{M}=$ Matematika teszt; $\mathrm{K}=$ Korai numerikus készségek teszt; Minden összefüggés $\mathrm{p}<0,001$ szinten szignifikáns.

A korai numerikus készségek és a matematika teszt kapcsolatának részletesebb vizsgálatához strukturális egyenletek modellezését (SEM) alkalmaztuk, amelyben elméleti modelljeink a mérés adataihoz való illeszkedését tudjuk ellenőrizni. Az elemzésekhez a korai numerikus készségek teszt és a matematika teszt teljes adatbázisát átemeltünk az MPlus programba. Az 
összes item nominális változóiból a programon belül számoltuk ki az egyes résztesztek értékeit, amelyeket azután a modellek változó szintjein használtunk fel. Összesen három hipotetikus modell illeszkedését elemeztük ki. A SEM-elemzés alapján kapott illeszkedésmutatókat a 39. táblázatban összesítettük. A SEM-modelleket bemutató ábrákon téglalappal az elemzésben a mért változókat, oválissal az elméleti változókat jelöltük, a nyilak pedig fordítva jelölik a regressziós hatások irányát.

39. táblázat. A SEM-modellek illeszkedésmutatói

\begin{tabular}{lcccccc}
\hline \multicolumn{1}{c}{ Modell } & $\chi^{2}$ & $\mathrm{df}$ & $\mathrm{p}$ & $\mathrm{CFI}$ & $\mathrm{TLI}$ & RMSEA (95\% CI) \\
\hline 1. modell & 363,41 & 26 & 0,001 & 0,972 & 0,961 & $0,055(0,050-0,060)$ \\
2. modell & 355,73 & 24 & 0,001 & 0,973 & 0,959 & $0,057(0,052-0,062)$ \\
3. modell & 37,48 & 12 & 0,001 & 0,996 & 0,994 & $0,022(0,014-0,031)$
\end{tabular}

Megjegyzés. $\mathrm{df}=$ degrees of freedom (szabadságfok); $\mathrm{CFI}=$ Comparative Fit Index; TLI = TuckerLewis Index; RMSEA = Root Mean Square Error of Approximation; $\mathrm{CI}=$ confidence interval.

Első SEM-modellünket úgy alkottuk meg, hogy az egyes résztesztek eredményei alapján képeztünk egy korai numerikus készségek és egy matematika faktort, ezt a két fő konstruktumot helyeztük az elemzés középpontjába. Az elemzéssel a közöttük lévő kapcsolat erősségét kívántuk ezzel ellenőrizni.

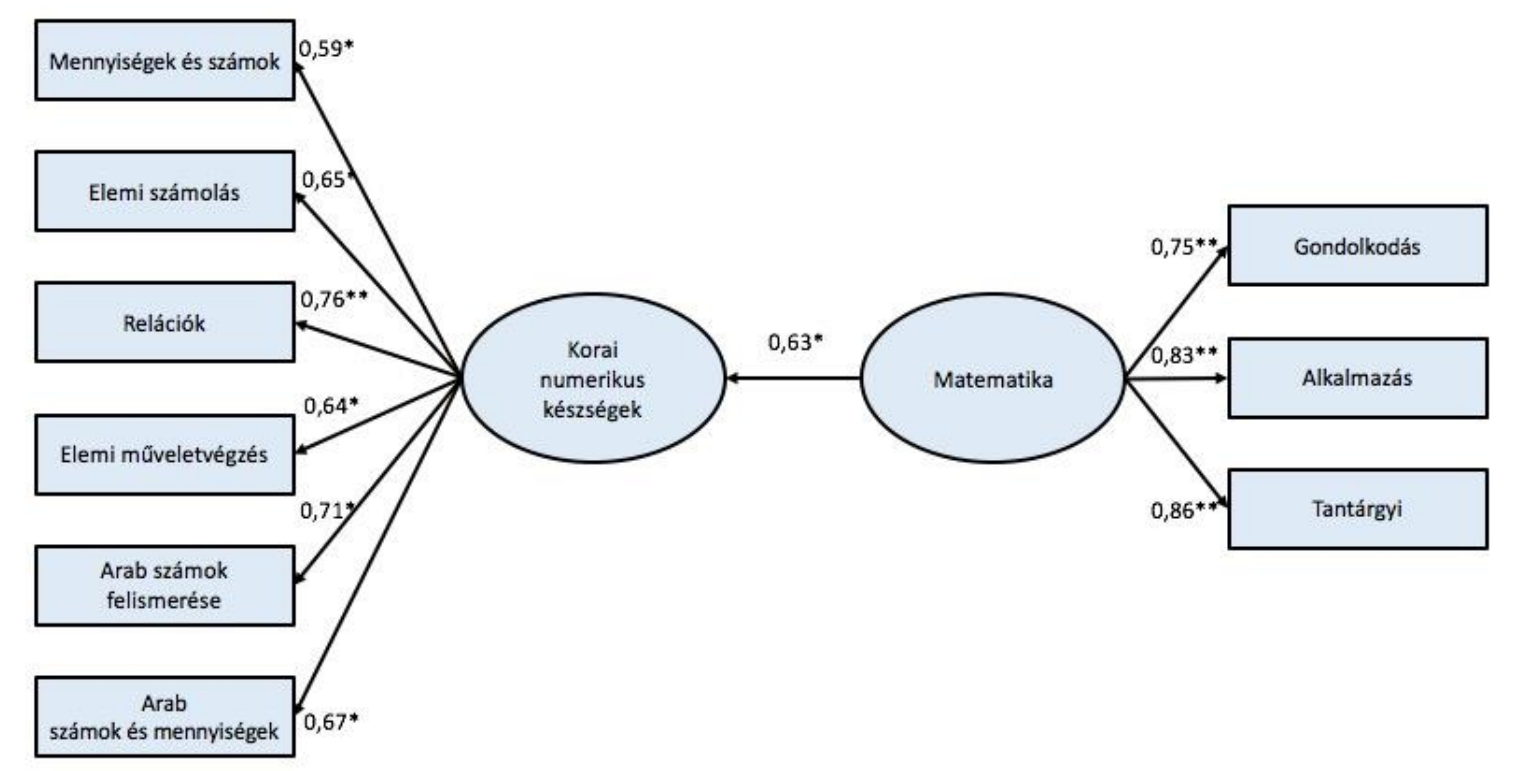

59. ábra

1. modell: A korai numerikus készségek és a matematika teljesitmény közvetlen kapcsolata

$$
(*=p<0,05 ; * *=p<0,01)
$$


Az első hipotetikus modell illeszkedése a mért adatainkhoz jó volt $(\mathrm{CFI}=0,972)$, viszont a RMSEA mutató értéke az ajánlott határértéken található, amelynek konfidencia intervalluma már kissé túl is nyúlik azon. Összeségében a modell illeszkedését elfogadhatónak tartjuk, így az egyes regressziós együtthatókat is áttekinthetjük. Ezek mindegyike szignifikáns, a szignifikanciaszint mértékét az 59. ábrán csillaggal jelöltük. Az ábrán látható, hogy a két fó komponens, a korai numerikus készségek és a matematika között közepes erősségü, szignifikáns hatás van, a standardizált regressziós együttható értéke meghaladja a 0,6-ot. Az egyes résztesztek magas értékkel csatlakoznak a modellben létrehozott két fö területhez, az együtthatók 0,59 és 0,86 közé esnek.

A következő, második modellünkben azt vizsgáltuk, hogy a modellben a résztesztek alapján létrehozott korai numerikus készségek közös faktora milyen hatást gyakorol az első tanév végén mért három matematikai területre, a gondolkodásra, alkalmazásra és a tantárgyi dimenzióra. A modell illeszkedése az előmodelléhez hasonlóan alakult, az illeszkedés jónak tekinthető ( $\mathrm{CFI}=0,973$; TLI=0,959), azonban az RMSEA értéke emelkedett. Utóbbi érték konfidenciaintervallumának felső határa így már meghaladta a 0,06-ot is. Valamint a két fö illeszkedésmutató a CFI és TLI között kisebb eltérés fedezhető fel, de ennek értéke nem haladja meg a másfél századot.

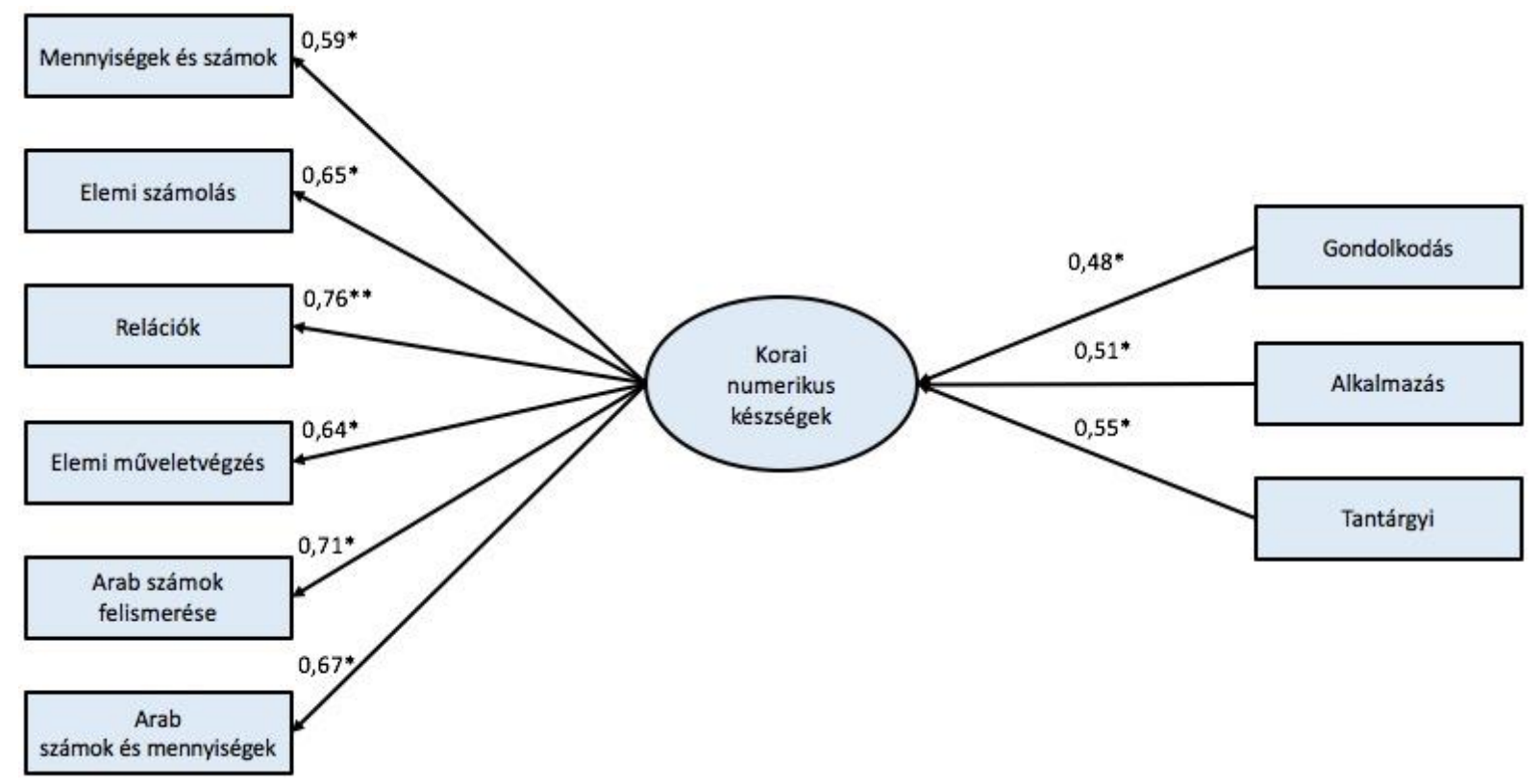

60. ábra

2. modell: A korai numerikus készségek és a matematika három dimenziójának kapcsolata

$$
(*=p<0,05 ; * *=p<0,01)
$$


A második SEM-modell (60. ábra) eredményei szerint, a résztesztekből magas együtthatókból összeálló, korai numerikus készségek közös konstruktuma szignifikáns hatással van mindhárom matematika dimenzióra. A legerösebb regressziós hatást a tantárgyi dimenziónál fedezhetjük fel $(0,55)$, ehhez képes valamivel alacsonyabb a két másik területre gyakorolt hatása $(0,48-0,51)$.

A SEM-elemzéseink során megalkotott utolsó, harmadik modellünkben (61. ábra) nem szerepeltettünk közös korai numerikus készségek faktort, a numerikus készségek egyes online formában felmért összetevőinek hatását külön-külön kívántuk megnézni az első évfolyam végi matematika teljesítményre, amely a már ismertetett gondolkodás, alkalmazási és tantárgyi dimenziókból jött létre. A harmadik SEM-modell illeszkedését is ellenőriztük, a CFI és TLI mutatói kiemelkedően magasak, mindkét mutató értéke 0,99 felett áll. Továbbá az RMSEA értéke is jóval az ajánlott határérték alatt helyezkedik el, így az utolsó modell illeszkedése kiválónak tekinthető.

A harmadik modell eredményei alapján azt tudjuk megállapítani, hogy a korai numerikus készségek egyes összetevői közül, amelyeket online formában tanév elején mértünk, melyek vannak jelentős hatással a matematika teljesítményre. A SEM-elemzés eredményeiből jól látszik, hogy bár mindegyik részteszt hatása szignifikáns, viszont a regressziós együtthatók értéke többségében alacsony, 0,1-es együttható felett csak az elemi számolás, arab számok felismerése, és a relációk részteszt hatása azonosítható. Utóbbi részteszt regressziós együtthatója a legmagasabb, 0,37-es.

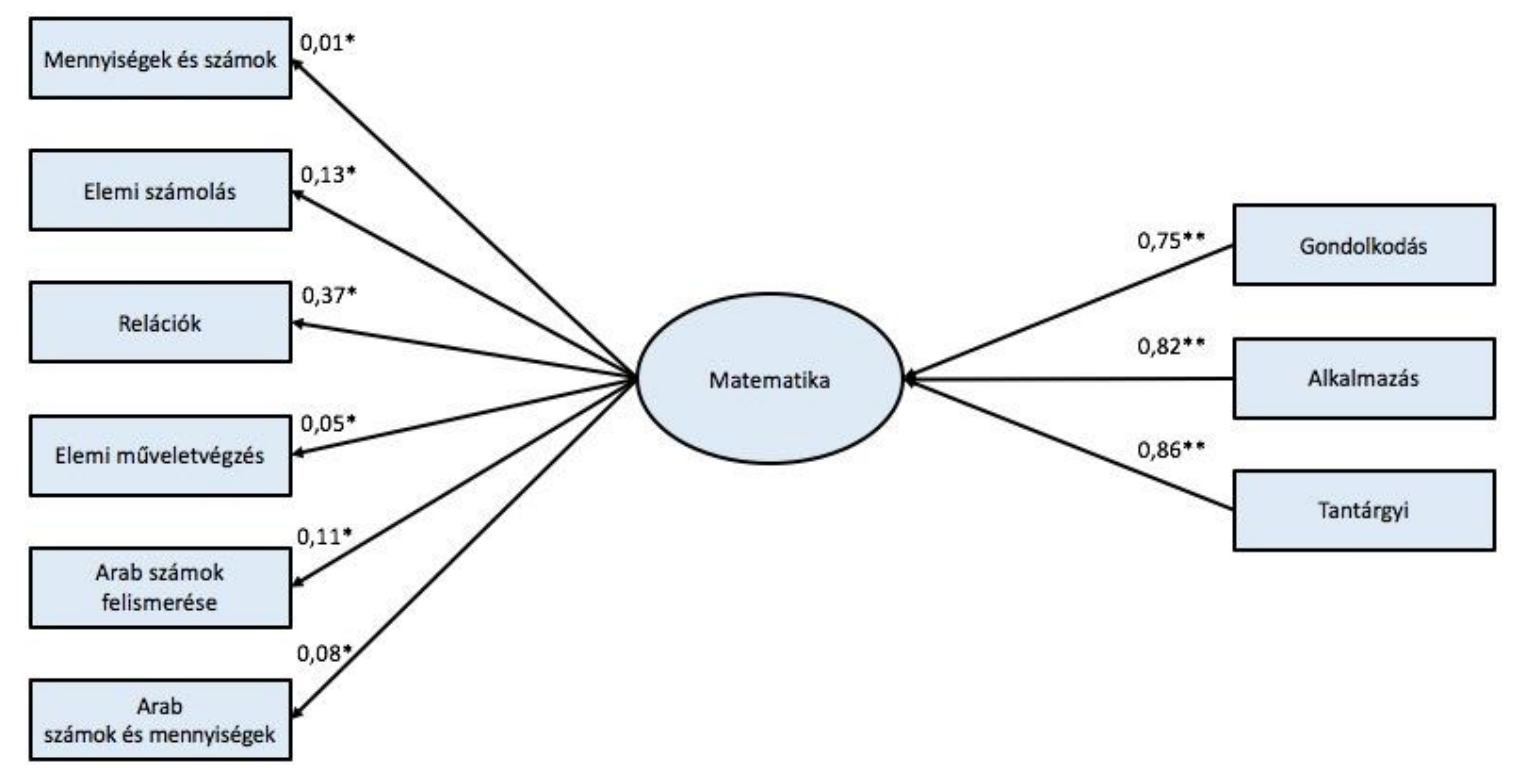

61. ábra

3. modell: A korai numerikus készségek összetevőinek és az iskolai matematika teljesitmény kapcsolata $(*=p<0,05 ; * *=p<0,01)$ 


\section{DISZKUSSZIÓ}

\subsection{A korai numerikus készségek teszt pszichometriai jellemzőinek megvitatása}

Jelen alfejezetünkben a korai numerikus készségek mindkét tesztváltozatának pszichometriai jellemzőit értelmezzük, amelyhez szervesen kapcsolódik a tesztfejlesztés folyamatának bemutatása és a második tesztváltozat kialakításának szempontjai. Továbbá kitérünk a jelenlegi tesztváltozat további fejlesztési lehetőségit is. Az eredményeink között egymást követően soroltuk fel a különféle módszereken alapuló pszichometriai jellemzőket, amelyek között kitárgyaltuk a tesztek a megbízhatóságát, az itemek elkülönítésmutatóit, részletesen foglalkoztunk a tesztek szerkezetével, konstruktum-validitásával, bemutattuk a teljes teszten és résztesztjein elért áltagos teljesítmények eloszlását, a feladatok nehézségének szintjeit, valamint kitértünk olyan további jellemzőkre, mint tesztidő és az eszközhasználat készségének kérdései.

Először az első tesztváltozat óvodai és iskolai méréseken feltárt jellemzőit tekintjük át. $\mathrm{Az}$ első óvodai mérés, több mint 300 óvodás részvételével zajlott, a tesztfelvétel mobilinterneten keresztül, tableteken történt, annak minden előnyével és hátrányával, amelyeket a technológia alapú mérés-értékelést kitárgyaló elméleti fejezetben már ismertettünk. Az első tesztváltozatnál a megbízhatóság és az érvényesség jellemzőinek feltárásánál is az elemi számolás részterülete volt problémás. Az első évfolyamon első tesztváltozatból az elemi számolás résztesztjéből több itemet is ki kellett vennünk, hogy a további elemzéseink megbízható eredményeken alapuljanak. Véleményünk szerint előfordulhat, hogy az alacsony elkülönítésmutatókat a feladatok nehézségi szintje okozta. Egyszerüen már nem mértek megfelelően a 7 éves átlagkorú gyerekek csoportjában, ahol a részteszt feladatai nem differenciáltak a tanulók között. Azt is figyelembe kell azonban vennünk, hogy az első évfolyam végi matematika tesztnek köszönhetően láthatóak az itemek prediktív validitásának értékei is, ahol szignifikáns kapcsolatokat láthatunk mindegyik elemi számolási feladatnál, tehát az a minimális differenciálás, pontosabban a maximum pontól való gyengébb teljesítmény előre mutathatja a későbbi iskolai teljesítményt. Ennél a résztesztnél egy feladat jelentősebb mértékben elkülönült a skála egészétől, ez az item, amely már a visszafelé számolást vizsgálta, a számkörök elörefelé történő átlépését mérő feladatok után következett, és már az óvodában sem müködött megfelelően. A váltás az előrefelé és visszafelé számlálás között feltehetően megzavarta a tanulókat. Ezért teszt átdolgozásakor ezen a ponton plusz, figyelemfelhívó instrukcióra is szükség lehet. Elsősorban az első évfolyamon végzett mérések 
pszichometriai jellemzői indokolták, hogy ezeket a dichotóm feladatokat teljesen lecseréljük a teszt átalakításakor.

Bár a relációk részteszt megbízhatósága az óvodában különösen magas volt, itt ebben összesen 15 feladatot alkalmaztunk, és különösebb problémát a 10 itemes rövidebb relációk résztesztnél sem találtunk az iskolában, mégis átdolgoztuk ezt a feladatsort is. Óvodában és iskolában egyaránt nagyon sok időt vettek el ezek a feladatok, ezért a teszt átdolgozásakor megpróbálkozunk az elkülönítésmutatók, és CFA eredményeire alapozva kiválasztani a 6 legjobban müködő itemet, amelyeket az óvodai validációs mérésen vetettünk be először. Sajnos kevés sikerrel, a rövidített feladatsor reliabilitása 0,3 alá esett, aminél a kevés feladatnak köszönhetően az egyes itemek ki- és beemelésének lehetőségét is elvesztettük. Az sikerült ugyanakkor elérni, hogy 3 perc alá szorítsuk le a gyermekek részteszten eltöltött idejét. Az arab számok felismerése résztesztünknél az első tesztváltozatban az óvodai és iskolai mérésen is ugyanazzal az egy itemmel volt probléma. Ez a feladat 3 számjegyü arab számok felismerésére vonatkozott, amely alacsony elkülönülés-mutatókkal rendelkezett az óvodai és iskolai tesztelésnél is, emellett a feladat szórása is kiemelkedően magas volt. A feladatra adott válaszoknál azonosítani tudtunk, hogy a tanulók nagy része a „170”-re kattintott, miközben a helyes válasz a „140” volt, feltételeztük, hogy a kérdéses disztraktor cseréjével javítani tudunk a feladaton. Ezt sikerült is elérnünk, a második tesztváltozatban már nem volt probléma ezzel az itemmel, cserébe kaptunk egy másik, korábban jól müködő feladatot. Az első, 10-es számkörön belüli arab szám felismerést mérö feladat megbízhatóságával voltak problémák, 0,2 alá csökkent az elkülönítésmutatója. A mennyiségek és számok részteszt és az elemi műveletvégzés kiváló pszichometriai mutatókkal rendelkezett. A teszt rövidítésének érdekében azonban össze kellett vonnunk azokat. Tekintve, hogy mennyiségek és számok feladatai a megszámlálást vizsgálják, így indokolt volt a többi manipulatív számolási müvelet közé helyezni azokat. Ennek eredményeképpen azonban kis mértékkel, de csökkent az összevont skála reliabilitása. A jövőben itt kisebb finomhangolásra lesz még szükség. Az átalakítás követően, bár az egyes résztesztek reliabilitás-mutatói mutatói kismértékben javultak, a teszt egészének megbízhatósága az óvodában lecsökkent a kiváló szint alá, de még a jónak tekinthető érteken maradt.

$\mathrm{Az}$ első hipotézisünk a teszt és résztesztjeinek megbízhatóságára vonatkozott. Összességében elmondható, hogy mindkét tesztváltozatnál, valamennyi mérésen megfelelő határérték felett voltak a reliabilitás-mutatók, így ezt a hipotézisünket sikerült igazolnunk.

Az első tesztváltozat konstruktum-validitása az óvodában és az iskolában is megfelelő volt, az egyes résztesztekre magas szinten kapcsolódtak a tesztitemek, és a résztesztek faktorai 
magas faktorsúlyokkal képezték a korai numerikus készségek közös faktorát. A megerősítő faktorelemzés eredményei alapján az új, négy dimenziós struktúra illeszkedésre még elfogadható volt. Így kijelenthető, hogy a második, konstruktum-validitásra vonatkozó hipotézisünket is igazoltuk.

A harmadik hipotézisünket egyelöre nem sikerült igazolnunk. A tesztfeladatok óvodában és iskolában nem lefedik teljes mértékben az alacsonyabb és magasabb képességszinteket, óvodai mérésen a közepes nehézségi szintű feladatokból kevesebb van a tesztben, az iskolai mérés pedig megmutatta, hogy az iskolás korcsoportban már nincsenek tesztfeladatok a magasabb képességszinteken. Az elvégzett Rasch-elemzések eredményei alapján az óvodában a képességszintek két végén sikerült megfelelő nehézségü feladatokat készíteni, az óvodában egy közepes nehézségi szintű feladatcsoport hiányzott. Az elemzések megmutatták, hogy az iskolai bemeneti mérésen már nem fedtük le a tanulók jobban teljesítő felét, számukra már nem jelentett kihívást a korai numerikus készségek teszt kitöltése. Az Rasch-elemzésben feltárt EAP/PV reliabilitás az első tesztváltozat óvodai és iskolai mérésein is elfogadható volt, az átalakítást követően viszont akárcsak a teszt Cronbach- $\alpha$ értéke ez is csökkent. Bár sikerült jobban lefedni a képességszinteket, a feladatok képességszintek szerinti eloszlása továbbra sem egyenletes.

Amint azt már más elemzéseknél részleteztük, a iskolai teszteredmények a relációk részteszt kivételével minden esetben erősen jobbra tolódtak az iskolai mérésen, így a jobb képességü gyermekeket a teszt már nem tudta megfelelően differenciálni. Ez hozzájárulhatott az egyes résztesztek alacsonyabb reliabilitás-mutatóihoz is. Ezzel tesztünk iskolai próbamérésén, amely szeptemberben zajlott, még nem szembesültünk ilyen mértékben, a résztesztek többségén elért teljesítmények közeledtek a normáleloszláshoz. A nagymintás mérésben résztvevő első évfolyamos tanulók számára már könnyủek voltak feladatok. Ennek egyik lehetséges magyarázata lehet, hogy bár a dolgozatban és a mérések kommunikációjában is folyamatosan iskolai bemeneti mérésről beszélünk, az első osztályos tanulók több mint 70\%a október második felében, több mint 50\%-a az őszi szünet után, már csak novemberben vett részt a méréseken. Nem hagyhatjuk figyelmen kívül azt, hogy az iskolai matematikatanításnak minden bizonnyal hatása volt ezekre az eredményekre. Amely jól megmutatkozik például az arab számokat tartalmazó résztesztek eloszlásainál. A jövőben ezért fontosnak tartanánk, hogy az iskolai bemeneti mérésekre szeptember és október folyamán kerüljön sor, hogy annak eredményeiben valóban az iskolára való felkészültség tükröződjön. Elemzéseink arra is rávilágítottak, hogy bár az eloszlások és a Rasch-elemzés eredményei alapján a jobb képességü tanulókat igazából már nem differenciáltuk, amennyiben a lemaradásban lévők feltérképezése 
a célunk, ez nem feltétlenül okoz komolyabb gondot, ugyanakkor a teszt pszichometria jellemzőit erőteljesen befolyásolja.

A negyedik hipotézist el kell vetnünk, mivel a teszt és a résztesztek eloszlása egyik változat esetében sem egyezett meg a normál eloszlással az óvodás korcsoportban sem, ugyanakkor azt a feltételezésünket igazoltuk, amely szerint az eloszlások jobbra tolódnak az első évfolyamos tanulók esetében.

Az ötödik hipotézisünket sikerült alátámasztanunk, mivel a korai numerikus készségek teszt, résztesztjei, itemei és az első évfolyam végi matematika teljesítmény között szignifikáns korrelációt találtunk, így az online teszt itemeinek prediktív validitásáról is információhoz jutottunk. Az első tesztváltozat összes iteme korrelált az első évfolyam végi matematika teszt eredményével, az is látható, hogy a nehezebb feladatok prediktív validitása volt magasabb.

A hatodik hipotézisünket is alátámasztottuk, az óvodai korcsoportban alacsonyabb átlagteljesítményt mértünk, amelyhez magasabb szórás társult, az első évfolyamos tanulók teljesítménye pedig magasabb volt és egyben alacsonyabb szórást tapasztaltunk. Ehhez is kapcsolódva igazoltuk a hetedik hipotézist, miszerint az óvodás és az iskolás korcsoportok között szignifikáns fejlődés mutatható ki a korai numerikus készségeik terén. Jelentős, magas hatásméretű fejlődést lehetett kimutatni a keresztmetszeti elemzések alapján.

Az első tesztváltozattal végzett mérésnél sajnos kevés terünk maradt az óvodás korcsoportban és az iskolások körében összehasonlítani a korai numerikus készségek teszten és a részteszteken elért teljesítményt, mivel már óvodában is jobbra tolódtak az eloszlások, amelyek az első évfolyamon még inkább eltolódtak. Ennek a plafoneffektusnak következtében a tanulók jelentős részének fejlődését már nem mértük az első évfolyamon. Az 5,7 és 7,1 átlagéletkorok között 21 százalékpontos fejlődést tapasztaltunk, amely emelkedés megmutatkozott a résztesztek szintjén is.

Méréseinknél, mivel a gyermekek neme, mint háttérváltozó rendelkezésünkre állt, minden esetben megvizsgáltuk a teljesítményben és eloszlásban tapasztalható eltéréseket. A fiúk és lányok közötti különbségek mértékében az óvodai és iskolai méréseken nem volt lényeges eltérés, a különbözőség-vizsgálatok eredményének szignifikancia szintjét az eltérő mintaelemszámok befolyásolhatták. Az óvodában százalékpontban nagyobb eltérés nem volt jelentős a párszáz fős gyerekcsoportnál, ugyanakkor egy-két százalékpontos eltérés már szignifikáns volt az első évfolyamos nagymintás mérésen. Az összetevőket nézve a lányok a a mennyiségek és számok, elemi müveletvégzés résztesztjein, a fiúk pedig az elemi számolás, arab számok felismerése feladatsorain teljesítettek jobban. Ennek érdekességét a feladatmegoldás módjában látjuk, mivel a lányok ezáltal a vonszolással megoldható 
feladatokban jeleskedtek, miközben a fiúk a kattintással megoldható feladatoknál értek el jobb teljesítményt. A feladatok tartalmát nézve a megszámlálás, kiegészítés, elvétel és bontás feladatain volt kevéssel jobb eredménye a lányoknak, a fiúknak pedig elsősorban az arab számok ismerete volt valamelyest fejlettebb.

A nyolcadik hipotézist nem tudtunk igazolni, gyermekek számítógéphasználati és tablet-használati jártassága bár minden mérésnél kiemelkedően magas volt, a teszteredmények minden esetben szignifikánsan összefüggöttek a korai numerikus készségek teszttel.

Ezek után továbbra is kérdésként merülhet fel, hogy az online tesztelési forma mennyiben feleltethető meg, vagy milyen mértékben helyettesítheti a szemtől szembeni tesztelést, ha a korai numerikus készségek összetevőinek teljes körét nem tudjuk lefedni. Ennek megválaszolására külön óvodai vizsgálatot szerveztünk, amelyben a korai numerikus készségek teszt és a DIFER elemi számolási készség tesztjének összehasonlítására került sor. A vizsgálat eredményei azt mutatják, hogy szignifikáns összefüggés van a két teszt között $(r=0,84 ; p<0,01)$.

$\mathrm{Az}$ online és szemtől szembeni teszteknél az egyes résztesztek szintjén is pozitív összefüggéseket találtunk, és a teljesen más formában vizsgált elemi számolás és számlálás területe is szignifikánsan korrelált. A validációs vizsgálat eredményei plusz információval szolgáltak a gyermekek tablet eszközhasználatának kérdéskörében is, mivel mérés során felvettük a DIFER relációszókincs tesztet is, amely szignifikánsan összefüggött az eszközhasználat a teszttel is. Ez a két teljesen eltérö konstruktum és tesztelési forma közötti összefüggés arra enged következtetni, hogy a tablet eszközhasználat teszt valami egészen mást is mér. Illetve, annak eredményét feltételezhetően befolyásolja a gyermekek beszédértése és szókincse. Itt kell azt is kiemelnünk, hogy a hagyományos interjús formát kiváltva, már az óvodások is pár fős kiscsoportokban, egyedül töltik ki az online teszteket. Tehát teljesen önálló feladatvégzést várunk el az egészen kis gyermekektől is. A beszédértés és a megfelelő alapszókincs fejlettsége befolyásolhatja az eredményeiket. A kérdés az, hogy ettől függetlenül a teszten elért gyengébb teljesítmény mutathatja-e, hogy a gyermek külön figyelmet igényel. Véleményünk szerint igen, és a gyermekek szürésére jelen formájában is használhatók ezek az online mérőeszközök. A tesztekkel azonosított gyermekekkel a pontos diagnózist szemtől szembeni méréssel lehet kiegészíteni, így lényegesen sok időt megtakarítva.

Tehát az eredményeink között ismertetett pszichometriai jellemzőkre alapozva, jelentős átdolgozást követően hoztuk létre a korai numerikus készségek teszt második változatát. Ebben lényegesen kevesebb feladat szerepelt, összevontunk két skálát, átdolgoztuk az elemi számolás teljes feladatsorát, valamint először lerövidítettük majd teljesen kivettük a relációk résztesztet. Az új tesztváltozattal végzett mérések egyelöre a pszichometriai jellemzők romlásával jártak, 
de úgy gondoljuk, hogy kisebb-nagyobb javításokkal megbízható és valid tesztet tudunk létrehozni, amely hatékony eszköz lehet a pedagógusok kezében.

Az elméleti fejezetekben ismertetett mérőeszközök jóságmutatóival összevetve az általunk kapott értékeket, elmondható, hogy a számszerüsíthető adatok tekintetében nem tapasztalható eltérés sem a teszt és résztesztek a megbízhatóságál, sem azok érvényességénél. Az általunk is mért 0,8-0,9-es Cronbach- $\alpha$ értékekkel találkozhatunk a leközölt nemzetközi vizsgálatokban is (Aunio et al, 2006; Józsa, 2004). A MARKO-D teszt Rasch-elemzésének eredményei szerint hasonló a reliabilitás-mutatók értéke, ugyanakkor a német teszt egyenletesebben fedi le a különböző képességszinteket (Langhorst et al., 2016).

\section{A korai numerikus készségek technológia alapú mérésének kihívásai}

A digitális technológia oktatásban való elterjesztésével foglalkozó nemzetközi társaság (ISTE) által kidolgozott keretrendszerhez viszonyítva (Smaldino, Lowther, Russell, \& Mims, 2008), és az SAMR modellt alapul véve (Romrell, Kidder, \& Wood, 2014) a kisgyermekek technológia alapú mérés-értékelésének különböző szintjeit határozhatjuk meg, amelyeknek megvalósításával már a mindennapi pedagógiai gyakorlatban is találkozhatunk.

Technológiai eszközt lehet használni a hagyományos papír alapú, valamint óvodás korban elsősorban szemtől szembeni felmérések rögzítéséhez. A tesztfelvétel rögzítése egy tabletbe, vagy laptopba segítheti az adminisztrációt, a pontszámok automatikusan összeadódhatnak egy egyszerü Excel tábla segítségével is. Ezen a szinten a technológia mindössze egy megszokott adminisztrációs feladat megkönnyítését segíti elö.

Ennél egy magasabb fokot jelenthet, ha a gyermek a manipulatív feladatokat a tableten oldja meg, a hangosan számolás eredményét viszont a pedagógus rögzíti az előző szintnél leírt módon, így kikerülve a technológiai korlátokat az elemi számolás vizsgálatánál. Ez a szint már nagyobb mértékben alkalmazza a technológiát, a gyermek már közvetlen kapcsolatba kerül magával a digitális eszközzel is. A pedagógusok leterheltségén lényegesen azonban nem enyhít, hiszen továbbra is egyesével kell elvégezniük a méréseket.

A következő szintnél a gyermekek már teljesen önállóan oldják meg a teszteket, az egyéni mérésnél hangrögzítés és automatikus kódolás lehetősége már biztosított, így a teszt korábbi felvevőjéből mérőbiztos válik, aki felügyeli a gyermek önálló munkáját, és ha szükséges be tud avatkozni. Mindez az objektivitást növeli, de a pedagógusok számára jelentős idő megspórolását nem jelenti, hiszen a hangos számolást nem tudjuk csoportosan, egyszerre 5-6 gyermeknél vizsgálni. A probléma áthidalását jelentheti, ha a mérések, amelyek különböző 
iskolakészültségi vizsgálati területeket is magukba foglalnak, tartalmaznak több csoportos, és egy önálló mérési alkalmat. Így a legtöbb feladatrész gyorsan lebonyolítható, a hangosan számolás pedig, akár más, nyelvi fejlettséget is mérő feladatrésszel együtt, egy különálló 20 perc körüli időtartamú egyéni elektronikus tesztelést jelentene. Ezeken a szinteken végig haladva juthatunk el oda, hogy technológiai alapon az iskolakészültséghez szükséges összetevők mérését minél szélesebb körben tudjuk felmérni és automatikusan kiértékelni.

Ami biztos, hogy a technológia alkalmazására megfelelően fel kell készíteni a pedagógusokat. Mint minden ilyen eszköznél, akár papír alapú, akár szemtől szembeni mérés is legyen, általában kézikönyv, részletes mérési útmutató, segédletek állnak a pedagógusok rendelkezésére, sok esetben külön képzéseket szerveznek a mérőeszközök használatának magabiztos használatához. Nem gondolhatjuk azt, hogy a technológia alkalmazásával ezt a kört megspórolhatjuk, hogy azonnal és automatikusan hatékony eszközök lesznek a pedagógusok kezében, ami értelemszerűen magával vonja az oktatás minőségének javulását is. Az elmúlt tíz évben már bebizonyosodott, hogy a technológia önmagában nem jelent megoldást az oktatás problémáinak megoldásaira, a nyomtatott tankönyvekhez hasonlóan lehet remek eszköz, de problémák forrása is, így a legtöbb annak alkalmazóin, a pedagógusokon múlik. Mi kutatók abban segíthetünk, hogy az eszközöket tudományosan megalapozott, empirikusan igazolt hatékonyságú tartalommal, tesztekkel, tananyagokkal, fejlesztőprogramokkal töltjük fel.

A kisgyermekkori tesztelésnél, óvodában különösen fontos, hogy alkalmazkodjunk a pedagógus mellett egy további szereplő, a gyermek igényeihez. Ezért is alkalmaztunk a méréseinket megelőzően egy számítógépes-egér, illetve tablet eszközhasználat tesztet, ami egyben gyakorló feladatsorként is funkcionált. Elsősorban a validációs mérésünk előzetes eredményei mutatják, hogy amikor kisgyermekeket önállóan akarunk tesztelni, akkor számos különböző tényezővel is számolnunk kell. Javasolt lehet a mérésektől függetlenül már korábban alkalmazni ilyen (gyakorló) feladatsorokat, amelyek beszédértés, szókincs területét is hangsúlyosabban megjelenítik. Ezek fejlettsége alapfeltétele minden további önálló, online formában tervezett mérésnek.

Igaz, az iskolakészültség fogalmának bemutatásakor az életkor, mint meghatározó iskolaérettségi mutató ellen szólaltunk fel, egyelöre azonban mégis annyi javaslatot fogalmazhatunk meg, hogy az átlagosan fejlődő gyermekeknél 5 éves életkor előtt nem javasoljuk önálló, online tesztek felvételét, mivel motorikus készségeik, beszédértésük és szókincsük még nem teszi lehetővé a tesztelésnek ezen formáját. 5 éves kortól fokozatosan lehetne a gyermekeket hozzászoktatni az ilyen vizsgálatokhoz, és első lépésként a már említett tablet eszközhasználat, beszédértés és szókincs tesztekkel kezdeni a felméréseket. Amennyiben 
ezeken egy előre meghatározott teljesítményszintet elérnek a kisgyermekek, akkor utána érdemes a többi alapkészség, esetünkben a korai numerikus készségek vizsgálatát elkezdeni, amely teszten így lehet biztosítani, hogy megbízható és érvényes, pedagógiai gyakorlatban felhasználható eredményt kapjunk.

\section{A longitudinális vizsgálat eredményeinek megvitatása}

Az első tesztváltozattal végzett iskolai bemeneti mérés és a minta nyomkövetése lehetővé tette, hogy kielemezzük a teszt előrejelző erejét, a korai numerikus készségek iskolai matematikatanulásra gyakorolt hatását. A korai numerikus készségek teszt iskolai bemeneti mérésként eléggé könnyünek bizonyult a vizsgált tanulók körében, továbbá nem is müködött olyan jól, mint az óvodai mérésen. Az eloszlások erőteljes jobbra tolódása, a plafoneffektus ellenére mégis szignifikánsan összefügg az első évfolyam végén felvett matematika teszttel. Az is megmutatkozott, hogy a teszt összes iteme korrelál az iskolai matematikateszttel. Az iskolai bemeneti mérés számolás tesztje nagymértékben magyarázta az évvégi matematika teljesítményt. Erre vonatkozó eredményünk összhangban van korábbi hasonló vizsgálatok adataival (Aunio \& Niemivirta, 2010; Jordan et al., 2009).

Az iskola kezdő szakaszában felmért korai numerikus készségek és az első év végi matematika teljesítmény kapcsolatának feltárásához strukturális egyenletek modellezését alkalmaztuk, amelynek mindhárom letesztelt elméleti modellje elfogadható illeszkedésmutatókkal rendelkezett. Ezek közül az első és a harmadik modell illeszkedése volt magasabb, így azok eredményét érdemes a jövőbeli elemzések során felhasználni. Az első modellben a korai numerikus készségek teszt résztesztjeiből álló számolási készségek közös faktorának hatását vizsgáltuk a szintén résztesztekből összeálló első évfolyam végi matematika teljesítményre. A modell eredményei alapján a korai numerikus készségek szignifikáns hatást gyakorolnak a tanulók matematika teljesítményére. A harmadik modellben pedig ugyanezt a korai numerikus készségek összetevőire lebontva is ki mutattuk, láthatóvá vált, hogy mindegyik összetevő szignifikáns hatással van a matematika teljesítményre, ezek közül a relációk részteszten elért eredmény volt a legerőteljesebb.

Bár a második modell illeszkedése nem volt tökéletes, ebből is fontos információkra tettünk szert, mivel láthatóvá vált, hogy a korai numerikus készségek leginkább a matematika tantárgyi területeinek teljesítményét befolyásolják. Az elméleti fejezetekben ismertettük az első két évfolyam matematika tantárgyi tartalmát, amelyekre vonatkozóan bemutattuk a számolási készségek jelentőségét. A számolási készségek főként a számok és algebra területét készítik 
elő, amely a kerettanterv alapján különösen hangsúlyosan van jelen az általános iskola első évében. Vizsgálatunk eredményei tehát alátámasztották ezeknek a korai numerikus összetevőknek az iskolakezdésben meghatározó szerepét, és egyben az utolsó, kilencedik hipotézisünket is sikerült igazolni.

\subsection{Vizsgálataink korlátai}

Az óvodás és iskolás korcsoportokban végzett korai numerikus készségeket feltáró vizsgálataink egyik elsődleges korlátja, hogy online tesztelési formában nem tudtuk teljesen lefedni az elméleti fejezetekben részletesen ismertetett számolási készségek teljes spektrumát. Bár több összetevő, például a manipulatív számolási műveleteket, mennyiséget és számok egymáshoz rendelését, arab számok felismerését, majd azok mennyiségekhez történő kapcsolását megbízhatóan és érvényesen tudtuk vizsgálni, az egyik legfontosabb összetevőt, a számok nevének ismeretét és azok helyes sorrendjét, vagyis az elemi számlálást csak közvetett formában voltunk képesek felmérni. Ennek megfelelően, a teljes korai numerikus készségek fejlettségéről csak becslést tudtunk adni.

A számok nevének és helyes sorrendjének ismeretét elsődlegesen a gyermekek beszéltetésével tudjuk felmérni. A teszt első változatában ezt dichotóm feladatokkal mértük, amelyeknél az instrukcióban hallott számsorokról kellett a gyermekeknek eldönteni, hogy azok helyesek-e. Elsősorban az iskolás tanulók átlageredményeinek eloszlásából látszik, hogy számukra ez meglehetősen egyszerü volt. Ugyanakkor a feladatokban túl nagy szerepet kaphat a tanulók munka memóriája, hiszem egymás után hat számnév sorrendjét kellett megfigyelniük, az adott pillanatban észlelni az esetleges hibát, majd ezt észben tartva rákattintaniuk a válaszuknak megfelelő jelre. Az ilyen eldöntendő, igen-nem kérdéseknél felmerülhet a véletlen találat valószínűségé is. A részteszten elért teljesítmény szinte pontosan $50 \%$ p, ez felkelti a gyanút, hogy a gyerekek jelentős része akár a feladatok tartalmától függetlenül kattintott, azonban megnéztük a helyes válaszok aranyát az egymást követő, egyre magasabb számköröket mérő feladatokban. Ezek alapján pedig kirajzolódik egy csökkenő tendencia, ahogyan egyre magasabb számkörök átlépését vizsgáljuk. Végül az első évfolyamos mérés eredményeire alapozva úgy döntöttünk, hogy átdolgozzuk ezt a résztesztet. Ezért a második tesztváltozatban már teljesen új formában jelent meg. A „Peti számol” elrendezésű feladatok összetettebbek voltak, mivel az instrukcióban a tanulók hallottak egy három számból álló számsort, amelyet követően három lehetséges folytatás közül kellett kiválasztaniuk a helyeset. A második tesztváltozattal végzett mérések eredményei egyelőre nem túl bíztatóak. Míg az első 
tesztváltozatban szereplő dichotóm feladatok túl könnyüek voltak, az új feladattípus sem érte el a célját. Kisgyermekek számára túlságosan nehéz lett, az összetett feladatban az ilyen egyszerü ismeretek mérését olyan mértékben befolyásolhatja a gyermekek munkamemóriája, beszédértése, feladatvállalása, hogy nem lehetséges pontosan a megcélzott összetevők fejlettségének feltérképezése. A teszt további fejlesztésénél ezt a résztesztet biztosan át kell újra dolgoznunk.

A dolgozatban ismertetett mérések további meghatározó kritikája lehet, hogy egészen kis gyermekeket is önállóan megoldandó feladatsorokkal vizsgáltunk. Az önálló feladatvégzésnek a vizsgált óvodás, főként 4-5 éves korcsoportokban még jelentős korlátai lehetnek. Ennél fogva önmagukban a teszt és instrukcióinak érthetősége, a feladatok minél egyszerübb megoldási módjai, és az esztétikus, gyermekekhez közeli illusztrációk, még nem jelentik azt, hogy valóban alkalmazkodtunk a kisgyermekek szükségleteihez. Még ha egy átlagosan fejlődő gyermekről is van szó, egy további nagyon fontos tényező lehet a vizsgálat időtartama is.

Az elméleti áttekintésünkben bemutatott szemtől szembeni adatfelvételhez kötött mérőeszközök jellemzőinél látható volt, hogy 25-30 perc is lehet egy 4-8 éveseknek szánt teszt felvétele. A MARKO-D tesztben ezt felismerve az illusztrációk minőségének és mennyiségének emelésével és kerettörténet, mesés tartalmi elemek integrálásával kívánták ellensúlyozni a tesztelés hosszabb időtartamát. Viszont hangsúlyozni szeretnénk, hogy az online tesztek felvételénél az önálló feladatvégzés mellett egy további tényező, hogy csoportosan több gyermeket is tesztelünk egyszerre. Ezért felmerül, hogy a gyermekek eszközhasználata mellett a feladattartásának is megfelelö szinten kell-e lennie ahhoz, hogy megbízható és érvényes eredményeket kapjunk. A második tesztváltozatnál már komolyan törekedtünk a teszt teljes időtartamának lerövidítésére. Ez egyelőre egyes pszichometriai jellemzők csökkenését hozta magával. Igazi megoldást az adaptivitás irányába való elmozdulás jelentheti. Továbbá a csoportos méréseknél mindig felmerülhet a társak befolyásoló hatása, hiszen egymást könnyen megzavarhatják a tesztek kitöltése közben, az instrukciók meghallgatásakor lemaradhatnak néhány fontos információról, vagy megnézhetik a mellettük lévő társuk feladatmegoldását. Emiatt a szociális készségek hatással lehetnek még a kognitív fejlődés elektronikus vizsgálatánál is. A tesztfejlesztés során ezeket az információkat pusztán kvantitatív elemzésekkel nem vagyunk képesek feltárni, és éppen ezért nem is tudnánk beépíteni a teszt további fejlesztésébe.

Mivel óvodai vizsgálataink mintáinak kiválasztását elsődlegesen az elérhetőség, és az intézmények együttmüködése határozta meg, így a numerikus készségek fejlődésére vonatkozó 
kérdések vizsgálatánál nem tudunk a gyermekek széles körére vonatkozó állításokat megfogalmazni. Az óvodai validációs mérés, igaz szigorúan ellenörzött körülmények között és alaposan megtervezve zajlott, a szemtől-szembeni vizsgálatok miatt egészen alacsony mintaelemszámmal zajlott, így annak eredményeit sem tudjuk általánosítani.

Bár az iskolai méréseink mintájának nagy elemszáma lehetőséget biztosítana számos további elemzés elvégzésére, a háttérváltozók hiánya szembetűnő. Korábbi vizsgálatokból tudjuk, hogy a családi háttér, szülők iskolázottsága és több más tényező is hatással van a számolási készségek fejlődésére a vizsgált időszakban (Józsa, 2014). A korai numerikus készségek teszt fejlesztésénél elsősorban a teszt, résztesztek és itemek pszichometriai jellemzőire hagyatkozunk, a gyermekek háttéradatai fontos plusz információval szolgálhatnak a mélyebb elemzések elvégzéséhez, továbbá a családi háttér meghatározó jelentősége miatt az iskolai matematika tanulásira gyakorolt hatás pontos kimutatásának is feltétele.

\subsection{További kutatási irányok}

Az utóbbi egy évtizedig nem történt jelentős áttörés a digitális eszközök iskolák és a tanítás-tanulás világában betöltött szerepét tekintve. Az iskola nehezen tud lépést tartani ezzel a gyors technológiai fejlődéssel és reagálni a körülötte megjelenő változásokra. Különböző digitális eszközök oktatási alkalmazása az óvodapedagógusok és tanítók munkáját is megkönnyíthetik ezek közül mi elsősorban a technológia alapú mérés értékelés eszközeire koncentráltunk. Céljaink között szerepel ennek a mérés-értékelési eljárásnak a tökéletesítése és elterjesztése az óvodák iskolaelőkészítő évében, és az általános iskola első évfolyamain.

Annak érdekében, hogy minél pontosabb képet adjunk a gyerekek számolásának fejlődéséről különösen fontosnak tartjuk az elemi számlálás mérési területének átgondolását, és új mérő feladatok kidolgozását erre a meghatározó területre. Ehhez fel kívánjuk használni az első és a második teszt változattal szerzett tapasztalatainkat, hiszen óvodában az első változat dichotóm feladatai még jól müködtek, ugyanakkor azok iskolai alkalmazása már nem célszerű. Továbbá, az átdolgozáskor törekedni fogunk arra, hogy e terület mérését minél kevésbé befolyásolja a gyermekek munkamemóriája.

Az óvodáskorú gyermekek longitudinális nyomkövetése is jövőbeli terveink között szerepel. A korai numerikus készségek fejlődése az óvodás évek alatt megy végbe, ennek a fejlődési folyamatnak a vizsgálatához, és komolyabb statisztikai elemzések elvégzéséhez, például látens növekedési modellezéshez is szükségszerü a nyomkövetés. Jelenleg csak keresztmetszeti vizsgálatot tudtunk végezni az óvodás és iskolás gyermekek egymástól 
független mintáinak összehasonlításával. A számolási készségek fejlődéséről egy longitudinális vizsgálat az óvodától az iskola első évfolyamáig sokkal pontosabb információkkal szolgálna.

Az óvodás és az iskolai méréseknél is nagyobb figyelmet szentelünk a gyermekek hátterének megismerésére a jövőben. Tervezzük további, elsősorban szülő iskolai végzettségére, otthoni tevékenységek körére vonatkozó háttérváltozók felvételét. Emellett, jövőbeli céljaink között egyik első helyen szerepel óvodában és iskolában is újabb, kvalitatív módszerekkel, elsősorban videó megfigyeléssel, továbbá szemmozgás-követéssel kiegészített vizsgálatok elvégzése, hogy még több információt kapjunk a tesztfeladatok kitöltéséről.

A fejlődésbeli lemaradások feltérképezését követően nem szabad megfeledkeznünk a felzárkóztatásról sem. A szürővizsgálatok legfontosabb célja felhívni a figyelmet azokra a tanulókra, akiknek gondjaik vannak a számolással. A mérőeszköz fejlesztésével párhuzamosan már elkezdtünk dolgozni korai matematikai felzárkóztató programok kidolgozásának is. Ennek egyik első lépésenként elvégeztük egy német matematikai fejlesztő program hazai adaptációját (Rausch \& Turainé Toldi, 2016). Az elvégzett fejlesztő kísérlet eredményei azt mutatják, hogy nagy szükség van ilyen, tudományos megalapozottsággal kidolgozott, mesés és játékos elemek felhasználó segédeszközökre a hazai óvoda matematikai nevelésben. A Mina és a vakond fejlesztőeszköz kifejezetten azoknak a gyerekeknek lehet segítség, akik különféle problémák és kudarcok eredményeképpen kezdik nem kedvelni a matematikát és a számolást. Az eszköz játékos elemekkel, mesés történetekkel, változatos tartalmú feladathelyzetekkel hozza újra közel hozzájuk a különféle a matematikai tartalmakat, fogalmakat.

A 21. században a számolási készségek fejlesztése, akár digitális eszközökkel megtámogatva is történhet, amelyre már több nemzetközi példát is látunk (Praet \& Desoete, 2014). Inkább iskolás korcsoportban, egyéni fejlesztés esetén, felzárkóztatási célból az adaptív tesztelési eljárásokhoz hasonlóan tudunk fejlesztő feladatokat készíteni, azokat játékos keretbe ágyazni (Pásztor, 2016). Az óvodai foglalkozásokat pedig megtámogathatjuk digitális eszközökkel, ahol lehetőség van szimulációk, színes illusztrációk felhasználására feladathelyzetek, problémahelyzetek szemléltetéséhez. Az érintőképernyőn pedig manipulatív számolási feladatok is könnyedén kivitelezhetők. A jövőben egy ilyen komplex számolási készségeket fejlesztő digitális eszközökkel megtámogatott programcsomag létrehozása egy további tervünk, amelyhez a most bemutatott és továbbfejlesztett online korai numerikus készségek teszt kiváló társ lehet. 


\section{0. ÖSSZEFOGLALÁS}

Munkánkban egy korai numerikus készségeket vizsgáló online teszt fejlesztésének folyamatát mutattuk be, amelyhez kapcsolódóan részletesen ismertettük az ehhez kapcsolódó óvodások és első évfolyamos tanulók körében végzett vizsgálataink eredményeit. A dolgozatot egy szakirodalmi áttekintéssel kezdtük, amelynek első részében a korai numerikus készségek fogalmát és fejlődését jártuk körül. Több empirikusan igazolt fejlődési modellt is ismertettünk, továbbá részletesen áttekintettünk és összehasonlítottunk már gyakorlatban alkalmazott, szemtől szembeni tesztelésre épülő, korai számolást mérő eszközöket. Fontosnak tartottuk, hogy a számolás fejlődésénél megmutassuk az óvodai és iskolai kereteket is, az óvodai matematikai nevelés tartalmát és az iskola első évfolyamainak matematikai tantárgyi kereteit. Az utolsó elméleti fejezetben a technológia alapú mérés-értékelés fogalmát és jellemzőit tárgyaltuk ki, ennek elején a digitális technológiai fejlődés oktatásra gyakorolt hatását bemutatva tértünk rá, a számtalan lehetőségre, ami a technológiai fejlődésnek köszönhetően rendelkezésünkre áll a pedagógiai mérés-értékelés viszonylatában. Azonban kitértünk azokra a kihívásokra, korlátokra, amelyek különösen kisgyermekek tesztelésénél merülhetnek fel. A korai numerikus készségek online tesztelése is számos lehetőséget hordoz magában, azonban a kihívások köre, amit le kell küzdenünk, legalább ilyen mértékü.

A korai numerikus készségek, amelyek kialakulása már az óvoda előtt megkezdődik, és fejlődésük nagyrészt az óvodai évek alatt történik, az iskolai matematikatanulás fontos alapját képezik, emiatt e terület a gyermekek iskolakészültségének vizsgálatánál is egyre hangsúlyosabban jelenik meg. Fontos, hogy a pedagógusok tisztában legyenek a rájuk bízott tanulók számolási készségeinek fejlettségével, hogy a gyengébben teljesítő tanulókra több figyelmet fordíthassanak. A jelenleg rendelkezésre álló mérőeszközök, bár pontos és részletes képet adnak a gyermekek készségeinek fejlettségéről, sok időt vesznek el a pedagógusoktól, sok esetben már csak akkor használják azokat, ha feltételezik, hogy valami probléma van a háttérben. Az online mérések során egy pedagógus egyszerre felmérhet több tanulót is, és a tesztek kiértékelése is automatikusan zajlik, így a teszt kitöltését követően azonnal látható a teszten elért teljesítmény. E célból kezdtük el saját mérőeszközünk fejlesztését, amely során törekedtünk technikai lehetőségek optimális kihasználására az életkori sajátosságok figyelembevételével együtt.

$\mathrm{Az}$ értekezésben bemutatott kutatásaink egy saját online mérőeszköz kifejlesztésére irányultak, amely segítségével gyorsan és megbízhatóan feltérképezhető az 5-7 éves gyermekek korai numerikus készségeinek fejlettsége az iskolakezdés időszakában. Bemutattuk a 
vizsgálatokhoz kidolgozott tesztváltozataink felépítését, és elemeztük az elvégzett mérések eredményeit. Elemzéseink során részletesen áttekintettük a teszt pszichometriai jellemzőit, amelyeket a diszkusszióban értékeltünk ki. Itt kitértünk kutatásunk korlátjaira és újabb kihívásaira is. Emellett megvizsgáltuk óvodás és első évfolyamos tanulók korai numerikus készségeinek fejlettségét, valamint longitudinális kutatásunknak köszönhetően kielemeztük a korai numerikus készségek első évfolyamos matematika teljesítményre gyakorolt hatását. Vizsgálataink eredményei alátámasztják több korábbi kutatás eredményét is, miszerint az iskolakezdés számolási készségeinek fejlettsége meghatározó a későbbi iskolai teljesítmény szempontjából (Aunio \& Niemivirta, 2010).

A dolgozatban részletesen leírt mérések a teszt jelenlegi állapotát tükrözik, amely egy sokéves tesztfejlesztési folyamat első fázisának tekinthető. Mint azt leírtunk, szükséges az eszköz további fejlesztése, amelynek eredményeként egy olyan mérőeszköz jöhet létre, amelyet széles körben, könnyen tudnak majd alkalmazni óvodapedagógusok és tanítók a rájuk bízott gyermekek számolási készségeinek felmérésére és a lemaradásban lévő gyermekek kiszürésére, illetve annak érdekében, hogy a mérések eredményire alapozva tervezhessék meg matematikai nevelö-oktató munkájukat. 


\section{IRODALOM}

Apró, M. (2013). A hazai iskolaérettségi vizsgálatok gyakorlata napjainkban. Iskolakultúra, 23(1), 52 71.

Arnold, D. H., Fisher, P. H., Doctoroff, G. L., \& Dobbs, J. (2002). Accelerating math development in Head Start classrooms. Journal of Educational Psychology, 94(4), 762.

Asztalos, K. (2017). Online, diagnosztikus, gyermekkori zenei észlelést mérő teszt alkalmazása iskolába lépö gyermekek körében. In D. Molnár É., Vígh T. (Eds.), PÉK 2017 [CEA 2017] XV. Pedagógiai Értékelési Konferencia [15th Conference on Educational Assessment]: program és absztraktkötet [program book and abstracts]. (p. 55) Szeged: SZTE BTK Neveléstudományi Doktori Iskola.

Asztalos, K. \& Rausch, A. (2014, November). A zenei percepciós képességek és az elemi alapkészségek összefüggés-vizsgálata 5-6 éves gyermekek körében. In XIV. Neveléstudományi Konferencia. Debrecen, 2014. november 6-7-8.

Aunio, P., \& Niemivirta, M. (2010). Predicting children's mathematical performance in grade one by early numeracy. Learning and individual differences, 20(5), 427-435.

Aunio, P., \& Räsänen, P. (2016). Core numerical skills for learning mathematics in children aged five to eight years-A working model for educators. European Early Childhood Education Research Journal, 24(5), 684-704.

Aunio, P., Aubrey, C., Godfrey, R., Pan, Y., \& Liu, Y. (2008). Children's early numeracy in England, Finland and People's Republic of China. International Journal of Early Years Education, 16(3), 203221.

Aunio, P., Hautamäki, J., \& Van Luit, J. E. (2005). Mathematical thinking intervention programmes for preschool children with normal and low number sense. European Journal of Special Needs Education, 20(2), 131-146.

Aunio, P., Hautamäki, J., Heiskari, P. \& Van Luit, J. E. H. (2006). The Early Numeracy Test in Finnish: Children's norms. Scandinavian Journalof Psychology, 47, $369-378$.

Aunola, K., Leskinen, E., Lerkkanen, M. K., \& Nurmi, J. E. (2004). Developmental dynamics of math performance from preschool to Grade 2. Journal of educational psychology, 96(4), 699.

Balázsi, I., Balkányi, P., Ostorics, L., Palincsár, I., Rábainé Szabó, A., Szepesi, I., Szipőcsné Krolopp, J., \& Vadász, Cs. (2014). Az Országos kompetenciamérés tartalmi keretei. Budapest: Oktatási Hivatal.

Balázsi, I., Lak, Á. R., Ostorics, L., Szabó, L. D., \& Vadász, Cs. (2016). Országos kompetenciamérés 2015. Országos jelentés. Oktatási Hivatal, Retrieved from https://www.oktatas.hu/ pub_bin/dload/kozoktatas/meresek/orszmer2015/Orszagos_jelentes_2015_2kor.pdf.

Barbu, O. C., Yaden Jr, D. B., Levine-Donnerstein, D., \& Marx, R. W. (2015). Assessing Approaches to Learning in School Readiness: Comparing the Devereux Early Childhood Assessment to an Early Learning Standards-Based Measure. AERA Open, 1(3) 1-15.

Báthory, Z. (2000). Tanulók, iskolák - különbségek. Egy differenciális tanitáselmélet vázlata. Budapest: Okker Oktatási Kiadó.

Bingimlas, K. A. (2009). Barriers to the successful integration of ICT in teaching and learning environments: A review of the literature. Eurasia Journal of Mathematics, Science \& Technology Education, 5(3). 
Blackwell, C. K., Lauricella, A. R., Wartella, E., Robb, M., \& Schomburg, R. (2013). Adoption and use of technology in early education: The interplay of extrinsic barriers and teacher attitudes. Computers \& Education, 69, 310-319.

Bryant, F. B., \& Satorra, A. (2012). Principles and practice of scaled difference chi-square testing. Structural Equation Modeling: A Multidisciplinary Journal, 19(3), 372-398.

Buckingham, D. (2007). Beyond technology: Children's learning in the age of digital culture. Cambridge, UK: Polity Press.

Chomsky, N. (2006). Language and mind. Cambridge University Press.

Cohen, L., Manion, L., \& Morrison, K. (2013). Research methods in education. Routledge.

Collins, A., \& Halverson, R. (2009). Rethinking education in the age of technology: The digital revolution and schooling in America. Teachers College Press.

C. Neményi, E. (2002). Az alsó tagozatos matematika tantárgy helyzete és fejlesztési feladatai. Új pedagógiai Szemle, 49(12).

Csapó, B, \& Molnár Gy. (2017). Assessment-based, personalised learning in primary eduction. In J. C., Spender, T. Gavrilova, \& G. Schiuma, (Eds.), Knowledge management in the 21st century: resilience, creativity and co-creation. Proceedings IFKAD2017. (pp. 443-249). St. Petersburg: Petersburg University.

Csapó, B. (1998). Az iskolai tudás. Budapest: Osiris.

Csapó, B. (2014). A szegedi iskolai longitudinális program. In J. Pál \& Z. Vajda (Eds.), Szegedi Egyetemi Tudástár 7. Bölcsészet- és társadalomtudományok (pp. 117-166). Szeged: Szegedi Egyetemi Kiadó.

Csapó, B., \& Pásztor, A. (2015). A kombinatív képesség fejlődésének mérése online tesztekkel. In B. Csapó, \& A. Zsolnai (Eds.), Online diagnosztikus mérések az iskola kezdő szakaszában (pp. 367386). Budapest: Oktatáskutató és Fejlesztő Intézet.

Csapó, B., Fejes, J. B., Kinyó, L., \& Tóth, E. (2014). Az iskolai teljesítmények alakulása Magyarországon nemzetközi összehasonlításban. In T. Kolosi \& I. G. Tóth (Eds.), Társadalmi Riport 2014 (pp. 110-136). Budapest: TÁRKI.

Csapó, B., Hódi, Á., Kiss, R., Pásztor, A., Rausch, A., \& Molnár Gy. (2017, Sept). Developing Online Diagnostic Instruments for Assessing Pupils' Skills at the Beginning of Schooling. 17th biennial conference of the European Association for Research on Learning and Instruction (EARLI). pp. 508509. Tampere, Finland, August 29-September 2, 2017.

Csapó, B., Lörincz, A., \& Molnár, G. (2012). Innovative assessment technologies in educational games designed for young students. In Assessment in Game-Based Learning (pp. 235-254). Springer, New York, NY.

Csapó, B., Molnár, G., \& Nagy, J. (2014). Computer-based assessment of school readiness and early reasoning. Journal of Educational Psychology, 106(3), 639-650.

Csapó, B., Molnár, G., \& Nagy, J. (2015). A DIFER tesztek online változatával végzett mérések tapasztalatai. In B. Csapó, \& A. Zsolnai (Eds.), Online diagnosztikus mérések az iskola kezdö szakaszában (pp. 199-223). Budapest: Oktatáskutató és Fejlesztő Intézet.

Csapó, B., Molnár, G., \& R. Tóth, K. (2008). A papír alapú tesztektől a számítógépes adaptív tesztelésig: a pedagógiai mérés-értékelés technikájának fejlődési tendenciái. Iskolakultúra, (3-4), 3-16.

Csapó, B., Molnár, G., Pap-Szigeti, R., \& R. Tóth, K. (2009). A mérés-értékelés új tendenciái: a papír és számítógép alapú tesztelés összehasonlító vizsgálatai általános iskolás, illetve főiskolás diákok 
körében. In I. Perjés, \& T. Kozma (Eds.), Új kutatások a neveléstudományokban. Hatékony tudomány, pedagógiai kultúra, sikeres iskola (pp. 99-108.) Budapest: Magyar Tudományos Akadémia.

Csíkos C., \& Verschaffel, L. (2011). A matematikai müveltség és a matematikatudás alkalmazása. In B. Csapó \& M. Szendrei (Eds.), Tartalmi keretek a matematika diagnosztikus értékeléséhez. (pp. 5997). Budapest: Nemzeti Tankönyvkiadó.

Csíkos, C., \& Csapó, B. (2011). A diagnosztikus matematika mérések részletes tartalmi kereteinek kidolgozása: elméleti háttér és gyakorlati kérdések. In B. Csapó \& M. Szendrei, (Eds.), Tartalmi keretek a matematika diagnosztikus értékeléséhez. (pp. 141-168). Budapest: Nemzeti Tankönyvkiadó.

Csíkos, C., \& Vidákovich, T. (2012). A matematikatudás alakulása az empirikus vizsgálatok tükrében. In Csapó B. (Ed.), Mérlegen a magyar iskola. (pp. 83-130) Budapest: Nemzeti Tankönyvkiadó.

Csíkos, C., Molnár, G., \& Csapó, B. (2015). A matematika online diagnosztikus mérések tartalmi kereteinek elméleti alapjai. In B. Csapó, Cs. Csíkos, \& Gy. Molnár (Eds.), A matematikai tudás online diagnosztikus értékelésének tartalmi keretei (pp. 15-28). Budapest: Oktatáskutató és Fejlesztő Intézet.

Dehaene, S. (2003). A számérzék. Budapest: Osiris.

Desoete, A., Stock, P., Schepens, A., Baeyens, D., \& Roeyers, H. (2009). Classification, Seriation, and Counting in Grades 1, 2, and 3 as two-Year Longitudinal Predictors for low Achieving in Numerical Facility and Arithmetical Achievement. Journal of Psychoeducational Assessment, 27(3), 252-264.

Dienes, Z. (1999). Épitsük fel a matematikát. Budapest: SHL.

Duncan, G.J., Dowsett, C.J., Claessens, A., Manuson, K., Huston, A.C., Klebanov, P., Pagani, L.S., Feinstein, L., Engel, M., Brooks-Gunn, J., Sexton, H. \& Duckworth, K. (2007). School readiness and later achievement. Developmental Psychology, 43, 1428-1446.

Ellemor-Collins, D. \& Wright, R.J. (2009). Structuring numbers 1 to 20: Developing facile addition and subtraction. Mathematics Education Research Journal, 21(2), 50-75.

EMMI (2012). 51/2012. (XII. 21.) számú EMMI rendelet - a kerettantervek kiadásának és jóváhagyásának rendjéröl. Budapest: Emberi Erőforrások Minisztériuma.

Fáyné Dombi, A., Hódi, Á., \& Kiss, R. (2016). IKT az óvodában: kihívások és lehetőségek. Magyar Pedagógia, 116(1), 91-117.

Friso-van den Bos, I., Kroesbergen, E. H., \& van Luit, J. E. (2014). Number sense in kindergarten children: Factor structure and working memory predictors. Learning and Individual Differences, 33, 23-29.

Fritz, A. \& Ricken, G. (2008). Rechenschwäche. München: Reinhardt.

Fritz, A., Ehlert, A. \& Balzer, L. (2013) Development of mathematical concepts as basis for an elaborated mathematical understanding. South African Journal of Childhood Education, 3(1), 38-67.

Fuson, K. (1992). Relationships between counting and cardinality from age 2 to age 8. In J. Bideaud, C. Meljac, \& J.-P. Fischer (Eds.), Pathways to number, (pp. 127-149.) Hillsdale, NJ: Erlbaum.

Gerlach, M. \& Fritz, A. (2011). Mina und der Maulwurf. Frühförderbox Mathematik. Cornelsen, Berlin.

Grabe, M., \& Grabe, C. (2007). Integrating technology for meaningful learning (5th ed.). New York: Houghton Mifflin Company.

Gredler, G. R. (1992). School readiness: Assessment and educational issues. Brandon, VT: Clinical Psychology Publishing. 
Griffin, P., \& Care, E. (Eds.). (2014). Assessment and teaching of 21st century skills: Methods and approach. Springer.

Hair, E., Halle, T., Terry-Humen, E., Lavelle, B., \& Calkins, J. (2006). Children's school readiness in the ECLS-K: Predictions to academic, health, and social outcomes in first grade. Early Childhood Research Quarterly, 21(4), 431-454.

Hargreaves, J. (2011). Vocational Training and Social Inclusion. At a Glance. National Centre for Vocational Education Research Ltd., Australia.

Higgins, J., Russell, M., \& Hoffmann, T. (2005). Examining the Effect of Computer-Based Passage Presentation on Reading Test Performance. Journal of Technology, Learning, and Assessment, 3(4).

Hu, L., \& Bentler, P. M. (1999). Cutoff criteria for fit indexes in covariance structure analysis: Conventional criteria versus new alternatives". Structural Equation Modeling: A Multidisciplinary Journal. 6(1), 1-55.

Hülber, L., \& Molnár, Gy. (2013). Papír és számítógép alapú tesztelés nagymintás összehasonlító vizsgálata matematika területén, 1-6. évfolyamon. Magyar Pedagógia, 113(4), 243-263.

Hwang, G. J., \& Chang, H. F. (2011). A formative assessment-based mobile learning approach to improving the learning attitudes and achievements of students. Computers \& Education, 56(4), 10231031.

Igács, J., Janacsek, K., \& Krajcsi, A. (2008). A Numerikus Feldolgozás és Számolás Teszt (NFSZT) magyar változata. Magyar Pszichológiai Szemle, 63(4), 633-650.

Jackson, D. L., Gillaspy Jr, J. A., \& Purc-Stephenson, R. (2009). Reporting practices in confirmatory factor analysis: an overview and some recommendations. Psychological methods, 14(1), 6.

Janurik M. \& Józsa K. (2012). A zenei képességek fejlődése és összefüggése néhány alapkészséggel egy három hónapos zenei fejlesztő kísérlet eredményei. In Kozma T. \& Perjés I. (Eds.), Új kutatások a neveléstudományokban 2011. (pp. 63-80) Budapest: MTA Pedagógiai Tudományos Bizottsága, ELTE Eötvös Kiadó.

Jordan, N. C., Glutting, J., \& Ramineni, C. (2010). The importance of number sense to mathematics achievement in first and third grades. Learning and individual differences, 20(2), 82-88.

Jordan, N. C., Kaplan, D., Locuniak, M. N., \& Ramineni, C. (2007). Predicting first-grade math achievement from developmental number sense trajectories. Learning Disabilities Research \& Practice, 22(1), 36-46.

Jordan, N. C., Kaplan, D., Nabors Oláh, L., \& Locuniak, M. N. (2006). Number sense growth in kindergarten: A longitudinal investigation of children at risk for mathematics difficulties. Child development, 77(1), 153-175.

Jordan, N. C., Kaplan, D., Ramineni, C., \& Locuniak, M. N. (2009). Early Math Matters: Kindergarten Number Competence and Later Mathematics Outcomes. Developmental psychology, 45(3), 850-867.

Józsa K. (2004). Az első osztályos tanulók elemi alapkészségeinek fejlettsége - Egy longitudinális kutatás első mérési pontja. Iskolakultúra, 14 (11) 3-16.

Józsa K. (2007). A számlálási készség kritériumorientált fejlesztése. In Nagy J. (Ed.), Kompetencia alapú kritériumorientált pedagógia (pp. 291-298). Szeged: Mozaik Kiadó.

Józsa K. (2014). A számolás fejlesztése 4-8 éves életkorban. Szeged: Mozaik Kiadó.

Józsa K. \& Zentai G. (2007). Hátrányos helyzetü óvodások játékos fejlesztése a DIFER Programcsomag alapján. Új Pedagógiai Szemle, 57(5) 3-17. 
Jurecka, A. \& Hartig, J. (2007). Computer- und netzwerkbasiertes Assessment. In J. Hartig \& E. Klieme (Eds.), Möglichkeiten und Voraussetzungen technologiebasiertr Kompetenzdiagnostik. Bundesministerium für Bildung und Forschung (BMBF) (pp. 37-48). Berlin: Bonn.

Kagan, S.L., Moore, E., \& Bradekamp, S. (1995). Reconsidering children's early development and learning: Toward common views and vocabulary. Washington, DC: National Education Goals Panel.

Kákonyi, L. (2014). Érettségi vizsgák a 21. század elején. Új pedagógiai szemle, 64(7-8), 104-113.

Kirschner, P. A., \& De Bruyckere, P. (2017). The myths of the digital native and the multitasker. Teaching and Teacher Education, 67, 135-142.

Kiss, R., Hódi, A., Tóth, E., \& B. Németh, M. (2016). Egy magyar nyelvủ online fonológiai tudatosság teszt reliabilitásának és validitásának vizsgálata. In Zsolnai A. \& Kasik L. (Eds.), A tanulás és nevelés interdiszciplináris megközelítése: XVI. Országos Neveléstudományi Konferencia: Program és absztraktkötet (p. 255) Szeged: SZTE BTK Neveléstudományi Intézet, MTA Pedagógiai Bizottság.

Klauer, K. J. (1997). A tanulás és a kognitív képességek fejlesztése. Iskolakultúra, 7(12), 85-92.

Kleemans, T., Peeters, M., Segers, E., \& Verhoeven, L. (2012). Child and home predictors of early numeracy skills in kindergarten. Early Childhood Research Quarterly, 27(3), 471-477.

Körmöci, K. (2014). Hová bújt a matematika? (I. kötet) Módszertani kézikönyv a gyermekek matematikai tapasztalatszerzésének óvodai lehetöségeihez, gyakorlati megközelitésben. Budapest: Sprint Kiadó.

Kőrösné Mikis, M. (2002). Az informatika tantárgy helyzete és fejlesztési feladatai. Új pedagógiai Szemle, 2002(6), 35-49.

Köznevelési törvény (2011). 2011. évi CXC. törvény a nemzeti köznevelésröl. Budapest: Országgyülés.

Krajcsi, A. (2010). A numerikus képességek zavarai és diagnózisuk. Gyógypedagógiai Szemle, 38(2), 93-113.

Krajcsi, A. (2014). Nyelvi reprezentáció a numerikus feladatokban. In Cs. Pléh \& Á. Lukács (Eds.), Pszicholingvisztika (Vol. 2, pp. 939-970). Budapest: Akadémiai kiadó.

Kyttälä, M., Aunio, P., Lehto, J. E., Van Luit, J., \& Hautamäki, J. (2003). Visuospatial working memory and early numeracy. Educational and Child Psychology, 20(3), 65-76.

Langhorst, P., Ehlert, A., \& Fritz, A. (2016). Realising pre-school mathematical education - a development-oriented math programme with special consideration of phonological language processing aspects. South African Journal of Childhood Education, 3(1), 68-99.

Lipton, J. S., \& Spelke, E. S. (2005). Preschool children's mapping of number words to nonsymbolic numerosities. Child Development, 76(5), 978-988.

Lőrincz, A., Molnár, G., Jeni, L., Tőzsér, Z., Rausch, A., Cohn, J. F., Csapó, B. (2013). Towards entertaining and efficient educational games. In NIPS 2013, Data Driven Education, Nevada, USA, 2013. december 05-10.

Magyar, A. (2012). Számítógépes adaptív tesztelés. Iskolakultúra, 22(6), 52-60.

Magyar, A. (2014). Adaptív tesztek készítésének folyamata. Iskolakultúra, 24(4), 26-33.

Magyar, A., Pásztor, A., Pásztor-Kovács, A., Pluhár, Zs., \& Molnár, Gy. (2015). A 21. században elvárt képességek számítógép alapú mérésének lehetőségei. In Z. Tóth (Ed.). Új Kutatások a Neveléstudományokban. Oktatás és nevelés - gyakorlat és tudomány (pp. 230-243). Debreceni Egyetem: MTA Pedagógiai Tudományos Bizottság. 
McCloskey, M. (1992). Cognitive mechanisms in numerical processing: evidence from acquired dyscalculia. Cognition, 44(1-2), 107-157.

Molnár, G. (2006). A Rasch-modell alkalmazása a társadalomtudományi kutatásokban. Iskolakultúra, 16(12), 99-113.

Molnár, G. (2010). Technológia-alapú mérés-értékelés hazai és nemzetközi implementációi. Iskolakultúra, 20(7-8), 22-34.

Molnár, G. (2011). Az információs-kommunikációs technológiák hatása a tanulásra és oktatásra. Magyar Tudomány, 172(9), 1038-1047.

Molnár, G. (2013). A Rasch modell alkalmazási lehetőségei az empirikus kutatások gyakorlatában. Budapest: Gondolat Kiadó.

Molnár, G. (2015). A képességmérés dilemmái: A diagnosztikus mérések (eDia) szerepe és helye a magyar közoktatásban. Géniusz Mühely: A magyar tehetségsegitö szervezetek szövetsége (MATEHETSZ) kiadványsorozata, 15(2), 16-29.

Molnár, G., \& Magyar, A. (2015). A számítógép alapú tesztelés elfogadottsága pedagógusok és diákok körében. Magyar Pedagógia, 115(1), 49-66.

Molnár, G., \& Pásztor-Kovács, A. (2015). A számítógépes vizsgáztatás infrastrukturális kérdései: az iskolák eszközparkjának helyzete és a változás tendenciái. Iskolakultúra, 25(4), 49-61.

Molnár, G., \& Pásztor, A. (2015a, November). A számítógép alapú tesztelés megvalósíthatósága kisiskolás korban: egér - és billentyüzethasználati képességek fejlettségi szintje. Paper presented at the XV. Országos Neveléstudományi Konferencia, Budapest. Abstract retrieved from http://onk2015.conf.uni-obuda.hu/wp-content/uploads/2015/01/

ONK_2015_tartalmi_osszefoglalok.pdf

Molnár, G., \& Pásztor, A. (2015b). A számítógép alapú mérések megvalósíthatósága kisiskolás diákok körében: első évfolyamos diákok egér- és billentyüzet-használati képességének fejlettségi szintje. Magyar Pedagógia, 115(3), 239-254.

Molnár, G., Magyar, A., Pásztor-Kovács, A., \& Hülber, L. (2015). A mérési-értékelési rendszer elektronikus alapokra helyezésével kapcsolatos helyzetelemzés. Budapest: Oktatási Hivatal.

Molnár, G., Papp, Z., Makay, G., \& Ancsin, G. (2015). eDia 2.3 Online mérési platform-feladatfelviteli kézikönyv. Szeged: SZTE Oktatáselméleti Kutatócsoport.

Muthén, B. O. (1993). Goodness of fit with categorical and other nonnormal variables. SAGE Focus Editions, 154, 205-205.

Muthén, L. K., \& Muthén, B. O. (2010). Mplus user's guide. Los Angeles, CA: Author.

Nagy J., Józsa K., Vidákovics T., \& Fazekasné Fenyvesi M. (2004a). Az elemi alapkészségek fejlődése 4-8 éves életkorban. Szeged: Mozaik Kiadó.

Nagy J., Józsa K., Vidákovics T., \& Fazekasné Fenyvesi M. (2004b). DIFER Programcsomag: Diagnosztikus fejlödésvizsgáló és kritériumorientált fejlesztö rendszer 4-8 évesek számára. Szeged: Mozaik Kiadó.

Nagy, J. (1980). 5-6 éves gyermekeink iskolakészültsége. Budapest: Akadémiai Kiadó.

Nagy, J. (1987). Prefer: Preventiv fejlettségvizsgáló rendszer 4-7 éves gyermekek számára. Budapest: Akadémiai Kiadó.

NAT (2012). 110/2012. (VI. 4.) Korm. rendelet a Nemzeti alaptanterv kiadásáról, bevezetéséröl és alkalmazásáról. Budapest: Magyarország Kormánya. 
Navarro, J. I., Aguilar, M., Alcalde, C., Marchena, E., Ruiz, G., Menacho, I., \& Sedeño, M. G. (2009). Estimación del aprendizaje matemático mediante la versión española del Test de Evaluación Matemática Temprana de Utrecht. European Journal of Education and Psychology, 2(2).

Neumann, I., Neumann, K., \& Nehm, R. (2011). Evaluating instrument quality in science education: Rasch-based analyses of a nature of science test. International Journal of Science Education, 33(10), 1373-1405.

Ng, W. (2015). New Digital Technology in Education: Conceptualizing Professional Learning for Educators. Springer International.

Nunes, T. \& Csapó, B. (2011). Developing and assessing mathematical reasoning. In B. Csapó \& M. Szendrei (Eds.), Framework for diagnostic assessment of mathematics. (pp. 17-56) Budapest: Nemzeti Tankönyvkiadó.

OECD (2016). PISA 2015 Assessment and Analytical Framework: Science, Reading, Mathematic and Financial Literacy. Paris: OECD Publishing.

Opfer, J. E., \& Siegler, R. S. (2012). Development of quantitative thinking. In K. Holyoak \& R. Morrison (Eds.), Oxford handbook of thinking and reasoning. Cambridge, UK: Oxford University Press.

Ostorics, L., Szalay, B., Szepesi, I., \& Vadász, Cs. (2016). PISA 2015. Összefoglaló jelentés. Budapest: Oktatási Hivatal.

Pásztor-Kovács, A. (2016). A kollaboratív problémamegoldó képesség mérésének elméleti és módszertani megfontolásai: egy pilot kutatás eredményei. Magyar Pedagógia, 116(1), 51-72.

Pásztor-Kovács, A., Magyar, A., Hülber, L., Pásztor, A., \& Tongori, Á. (2013). Áttérés online tesztelésre - a mérés-értékelés új dimenziói. Iskolakultúra, 23(11), 86-100.

Pásztor, A. (2017). Tanulói szintű visszacsatolás és fejlesztés: technológia alapú mérések alkalmazási lehetőségei a mindennapi pedagógia gyakorlatban. In Gy. Hunyady, B. Csapó, G. Pusztai, \& J. Szivák (Eds.), Az oktatás korproblémái (pp. 202-212). Budapest: ELTE Eötvös Kiadó.

Pásztor, A. \& Molnár, G. (2016). Online assessment of inductive reasoning at primary school entrance. In Molnár Gy. \& Bús E. (Eds.), PÉK 2016. XIV. Pedagógiai Értékelési Konferencia - 14. Conference on Educational Assessment. Program; Elöadás-összefoglalók - Program; Abstracts. (pp. 75) Szeged: SZTE BTK Neveléstudományi Doktori Iskola.

Perlai, R. (1997). A matematika nevelés módszertana. Budapest: Nemzeti Tankönyvkiadó.

Peters, M. A. (2017). Technological unemployment: Educating for the fourth industrial revolution. ournal of Self-Governance and Management Economics, 5(1), 25-34.

Peucker, S., \& Weißhaupt, S. (2013). Development of numerical concepts. South African Journal of Childhood Education, 3(1), 21-37.

Praet. M., \& Desoete, A. (2014) Enhancing young children's arithmetic skills through non-intensive computerised kindergarten interventions: A randomised controlled study. Teaching and Teacher Education, 39, 56-65.

R. Tóth, K. és Molnár, Gy. (2010, April). Kisiskolás diákok gondolkodási képességének vizsgálata online környezetben. Paper presented at VIII. Pedagógiai Értékelési Konferencia. Szeged, 2010. április 16-17. 56.

Rausch, A. (2016a June). Online Assessment of Early Numerical Skills in Kindergarten - Results of a Pilot Study. Paper presented at the 21st Conference of the JUnior REsearchers of EARLI, Helsinki 
Rausch, A. (2016b). Online Assessment of Early Numeracy at School Entry. In Csíkos, C., Rausch, A. Szityányi, J. (Eds.), Proceedings of 40th Conference of the International Group for the Psychology of Mathematics Education. Volume 1 (pp. 226). Szeged: PME.

Rausch, A. (2016c). Lehetőségek és kihívások a számolási készségek online mérésében In: Misley, H. (Ed.), Digitális pedagógus és nemzedék konferencia - Konferenciakötet. (pp. 61-62.) Budapest: ELTE PPK Neveléstudományi Intézet.

Rausch, A. (2017). Korai számolási készségek online mérése első évfolyamos tanulók körében In Zsolnai A., Kasik L. (Eds.), Új kutatások a neveléstudományokban 2016: A tanulás és nevelés interdiszciplináris megközelitése (pp. 193-208). Szeged: SZTE BTK Neveléstudományi Intézet, MTA Pedagógiai Bizottság.

Rausch, A., \& Pásztor, A. (2017). Exploring the Possibilities of Online Assessment of Early Numeracy in Kindergarten. In B. Kaur, W.K. Ho, T.L. Toh, \& B.H. Choy (Eds.), Proceedings of the 41 st Conference of the International Group for the Psychology of Mathematics Education, Vol. 4. (pp. 89-96) Singapore: PME.

Rausch, A., Debreczeni, D.G., \& Szabó, D.F. (2014). Training Early Mathematical Skills: Hungarian Adaptation of the Mina and the Mole. In. E. Korom \& A. Pásztor (Eds.), CEA $2014-12$ th Conference on Educational Assessment. Program - Abstracts. Szeged: University of Szeged

Resnick, L. B., \& Klopfer, L. E. (1989). Toward the Thinking Curriculum: Current Cognitive Research. $A S C D$ Yearbook. Alexandria, VA: Association for Supervision and Curriculum Development.

Ricken, G., Fritz, A. \& Balzer, L. (2013a). MARKO-D. Mathematik und Rechnen - Test zur Erfassung von Konzepten im Vorschulalter [MARKO-D. Mathematics and arithmetics - test for assessing concepts in pre-school age]. Göttingen: Hogrefe.

Ricken, G., Fritz, A., \& Balzer, L. (2013b). Mathematik- und Rechnen - Test zur Erfassung von Konzepten im Vorschulalter (MARKO-D) - ein Beispiel für einen niveauorientierten Ansatz. Empirische Sonderpädagogik, 3(3), 256-271.

Romrell, D., Kidder, L. C., \& Wood, E. (2014). The SAMR model as a framework for evaluating mLearning. Journal of Asynchronous Learning Networks, 18(2).

Sarnecka, B. W., \& Carey, S. (2008). How counting represents number: What children must learn and when they learn it. Cognition, 108(3), 662-674.

Schrum, L., \& Levin, B. B. (2016). Educational technologies and twenty-first century leadership for learning. International Journal of Leadership in Education, 19(1), 17-39.

Scott-Little, C., Kagan, S. L., \& Frelow, V. S. (2006). Conceptualization of readiness and the content of early learning standards: The intersection of policy and research?. Early Childhood Research Quarterly, 21(2), 153-173.

Seufert, S., \& Scheffler, N. (2016). Developing Digital Competences of Vocational Teachers. International Journal of Digital Literacy and Digital Competence (ILDLDC), 7(1).

Skemp, R. R. (1975). A matematikatanulás pszichológiája. Budapest: Gondolat Kiadó.

Smaldino, S. E., Lowther, D. L., Russell, J. D., \& Mims, C. (2008). Instructional technology and media for learning.

Snow, C. E., \& Van Hemel, S. B. (Eds.). (2008). Early childhood assess- ment: Why, what, and how. Washington, DC: National Academies Press.

Snow, K. L. (2006). Measuring school readiness: Conceptual and practical considerations. Early education and development, 17(1), 7-41. 
Spector, J. M., Ifenthaler, D., Sampson, D., Yang, L. J., Mukama, E., Warusavitarana, A., ... \& Bridges, S. (2016). Technology enhanced formative assessment for 21 st century learning. Journal of Educational Technology \& Society, 19(3), 58.

Starkey, P. \& Cooper, R.G. (1995). The development of subitizing in young children. British Journal of Developmental Psychology, 13, 399-420.

Steklács, J. (2014). Szemmozgás, olvasás, információfeldolgozás. Anyanyelv-pedagógia, 7(3)

Szendrei, J., \& Szendrei, M., (2011). A matematika tanításának és felmérésének tudományos és tantervi szempontjai In B. Csapó, B. \& M. Szendrei, (Eds.), Tartalmi keretek a matematika diagnosztikus értékeléséhez. (pp. 99-140). Budapest: Nemzeti Tankönyvkiadó.

Torda, A. (2016, June). Az iskolakészültség állapotfelmérő próba projekt bemutatása. Presentation at Educatio szakmai rendezvénye: Vizsgálóeljárás az iskolába lépéshez szükséges fejlettség felméréséhez. Budapest, 2015. június 25.

Tóth-Mózer, Sz. \& Kárpáti, A. (2016). A digitális kompetencia kognitív dimenziója és összefüggésrendszere egy empirikus kutatás tükrében. Magyar Pedagógia, 116(2), 121-150.

Tóth, E., Molnár, Gy., \& Csapó, B. (2011). Az iskolák IKT-felszereltsége - helyzetkép országos reprezentatív minta alapján. Iskolakultúra, 10-11, 124-137.

Török, B. (2007). Az óvodai csoportszobai számítógépek. Iskolakultúra, 17(4), 115-126.

Török, T., Hódi, Á., \& Kiss Renáta (2016). A fonológiai tudatosság online mérési lehetőségei az általános iskola első négy évfolyamán. Alkalmazott Pszichológia, 16(1), 83-99.

Van de Rijt, B. A. M., Van Luit, J. E. H., \& Pennings, A. H. (1999). The construction of the Utrecht early mathematical competence scales. Educational and Psychological Measurement, 59(2), 289309.

Van Luit, J. E. H., Van de Rijt, B. A. M., \& Hasemann, K. (2001). OTZ Osnabrücker Test zur Zahlbegriffsentwicklung [German version of the Utrecht Test of Number Sense]. Göttingen, Germany: Hogrefe-Verlag.

Van Luit, J. E. H., Van de Rijt, B. A. M., \& Pennings, A. H. (1994). Utrechtse getalbegrip toets [early numeracy test]. Doetinchem, The Netherlands: Graviant.

Van Luit, J. E., \& Schopman, E. A. (2000). Improving early numeracy of young children with special educational needs. Remedial and special education, 21(1), 27-40.

Villányi, Gy. (1993). Játék a matematika? Matematika játékok gyüjteménye óvodapedagógusoknak. Budapest: Tárogató Kiadó.

Voogt, J., Fisser, P., Pareja Roblin, N., Tondeur, J., \& van Braak, J. (2013). Technological pedagogical content knowledge-a review of the literature. Journal of computer assisted learning, 29(2), 109-121.

Wright, R. J. (2013). Assessing early numeracy: Significance, trends, nomenclature, context, key topics, learning framework and assessment tasks. South African Journal of Childhood Education, 3(2), 21 40.

Wright, R., Stanger, G., Stafford, A., \& Martland, J. (2006). Teaching number in the classroom with 4to 8-year-olds. London: Sage.

Wright, R.J., Martland, J., \& Stafford, A. (2006). Early numeracy: Assessment for teaching and intervention (2nd Edition). London: Sage.

Wynn, K. (1992). Addition and subtraction by human infants. Nature, 358, 749-750. 


\section{KÖSZÖNETNYILVÁNÍTÁS}

Mindenekelőtt köszönöm témavezetőmnek, Csapó Benőnek a folyamatos iránymutatást, kiemelkedő támogatást és mindazt a számtalan lehetőséget, amelyek elindítottak és elöre vittek a neveléstudományi kutatói pályán.

Hálásan köszönöm kollégámnak és barátomnak, Pásztor Attilának a folyamatos szakmai és emberi támogatást, amellyel az elmúlt években segített átvészelni a kutatói munka legsötétebb óráit is, amin felül házi opponensként még a dolgozat alapos bírálatával is segítette az értekezés elkészülését.

Köszönöm tanáromnak, kollégámnak és házi opponensemnek, Csíkos Csabának a dolgozat formálásában nyújtott segítségét, értékes észrevételeit és tanácsait, valamint a tanulmányaim során átadott kutatásmódszertani alapokat, amelyekre bátran építhetek azóta is.

Hálás vagyok a Szegedi Mủhely minden egyes munkatársának, akiktől már az egyetemi évek alatt rengeteget tanultam, később kollégaként segítették munkámat a doktorképzés időszaka alatt. Közülük is kiemelten köszönöm B. Németh Máriának, a tesztfejlesztés során nyújtott szakértő támogatását, Betyár Gábornak és Halof Ferencnek az informatikai támogatást, Fejes József Balázsnak, aki a mesterszak alatt témavezetöként segítette a tudományos diákköri munkámat, majd szakdolgozatom megszületését is, Józsa Krisztiánnak a kutatásmódszertan és statisztika terén tanultakat, Kállai Istvánnak a feladatszerkesztési segítségét, Kinyó Lászlónak, számtalan tanácsát és támogatását, Kiss Renátának az óvodai mérések megszervezésénél nyújtott munkáját, Kléner Juditnak, Pappné Vreczkó Stellának, Nagy Krisztinának és Virág Petrának ügyes-bajos adminisztrációs teendőim megkönnyítését, Korom Erzsébetnek a doktorképzés és a doktori eljárás során nyújtott kiemelkedő segítségét, Markku Niemivirtának, akinek az (akadémiai) életben való maradáshoz kapcsolódó tanácsai legalább olyan hasznosak voltak, mint a haladó statisztika-kurzusai, Molnár Edit Katalinnak, akinek meglátásai és javaslatai mindig előre vitték a munkáimat, Molnár Gyöngyvérnek a folyamatos támogatást és az eDia mérés-értékelési rendszer biztosítását kutatásaimhoz, Molnár Katalinnak, akivel mindig öröm közösen konferenciát szervezni, és aki gondosan ügyelt minden kutatási munka hátterére, Szabó Dóra Fanninak értékes meglátásait és kutatások során nyújtott segítségét, Vidákovich Tibornak a sok szakmai tanácsot, amellyel kutatásaimat a szemináriumok alatt és azokon kívül is segítette, Vígh Tibornak, akitől a pedagógiai értékelés és a neveléstudományi statisztikai módszerek alapjait elsajátítottam, és köszönöm mindenkinek, aki Szegeden segített az elmúlt évek alatt.

Hálás vagyok Demetrovics Zsoltnak, akinek az elmúlt két év kiváló munkakörülményeit köszönhetem, valamint kollégáimnak Czető Krisztinának, Fehérvári Anikónak, Lénárd Sándornak, Paksi Borbálának, Széll Krisztiánnak és Zsolnai Anikónak az ELTE Neveléstudományi Intézetében folyamatos támogatásukért, és értékes meglátásaikért, amelyek új szemléletet is közvetítettek számomra. Köszönöm a DOSz Pszichológia és Neveléstudományi Osztály alapító csapatának, Maráz Anikónak, Király Orsolyának és Uatkán Ajnának a workshopjainkon és konferenciáinkon nyújtott visszajelzéseiket, ötleteiket.

Nagy köszönet a doktori védöhálómnak, a PhD-s kispajtások csapatának, különösképp Asztalos Katának, Dancs Katinkának, Dombi Edinának, Győri-Dani Dórának, Pásztor-Kovács Anitának és Török Tímeának, akik megóvtak a korai kiégéstől. Köszönöm legjobb barátomnak, Turi Gergőnek munkáim nyelvi lektorálásában nyújtott segítségét.

Végül, de nem utolsó sorban hálásan köszönöm Édesanyámnak és Öcsémnek a folyamatos támogatást, amely nélkül nem jutottam volna eddig. 


\section{ÁBRÁK JEGYZÉKE}

1. ábra. Numerikus megismerésben szerepet játszó rendszerek és reprezentációk ...................9

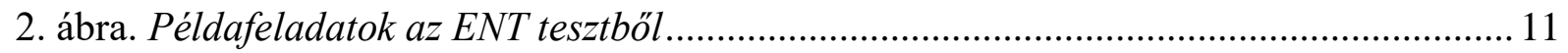

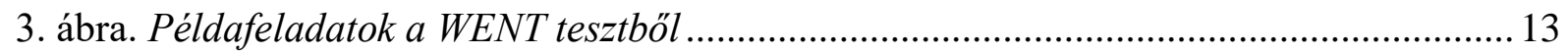

4. ábra. Példafeladatok a MARKO-D tesztböl fejlödési szintenként ....................................... 15

5. ábra. Számképfelismerés részteszt feladatai a DIFER Elemi számolási készség tesztböl ....18

6. ábra. Alapvető számolási készségek a matematika tanulásához 5-8 éves gyermekeknél ....24

7. ábra. A korai numerikus készségek egyes összetevőinek fejlödése 5-6 éves korban.............26

8. ábra. Az iskolai matematikateljesitmény szintjét és változását előrejelzö tényezők ..............26

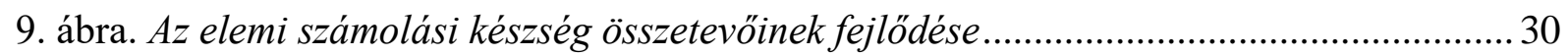

10. ábra. A magyar tanulók teljesítménye 2003 és 2015 között az OECD PISA matematika területén......

11. ábra. A technológia alapú, a számitógép alapú, a hálózat és internetalapú mérés-értékelés hierarchikus viszonya.... .46

12. ábra. Példafeladat a mennyiségek és számok résztesztböl 65

13. ábra. Példafeladat a mennyiségek és számok résztesztböl 65

14. ábra. Példafeladat az elemi számolás résztesztböl 66

15. ábra. Példafeladat az elemi számolás résztesztböl 66

16. ábra. Példafeladat a relációk résztesztböl. 67

17. ábra. Példafeladat a relációk résztesztböl 67

18. ábra. Példafeladat az elemi müveletvégzés résztesztböl. 67

19. ábra. Példafeladat az elemi müveletvégzés résztesztböl . 67

20. ábra. Példafeladat az arab számok felismerése résztesztböl . .68

21. ábra. Példafeladat az arab számok felismerése résztesztböl .... 68

22. ábra. Példafeladat az arab számok és mennyiségek résztesztböl 68

23. ábra. Példafeladat az arab számok és mennyiségek résztesztböl 68

24. ábra. Példafeladat az elemi müveletvégzés résztesztböl ..... 70

25. ábra. Példafeladat az elemi müveletvégzés résztesztböl . 70

26. ábra. Példafeladat az elemi számolás résztesztböl. .71

27. ábra. Példafeladat az arab számok felismerése résztesztből . .71

28. ábra. Példafeladat a mennyiségek és számok résztesztböl .71

29. ábra. Példafeladat a mennyiségek és számok résztesztböl .71

30. ábra. DIFER Elemi számolási készség teszt 72

31. ábra. DIFER Relációszókincs 1. Tesztváltozat..... 74

32. ábra. A mérések tartalmának több szempontú elrendezése. .75 
33. ábra. Az első évfolyam végi matematika teszt példafeladatai

34. ábra. Példafeladatok a Számítógépes-egér használat és Tablet eszközhasználat tesztekböl

35. ábra. Példafeladatok a Tablet eszközhasználat tesztböl és a Korai numerikus készségek tesztböl..

36. ábra. Az óvodai mérések eszközei és technikai megvalósitása

37. ábra. Az iskolai mérések technikai megvalósitása.....

38. ábra. Az itemek elkülönités mutatóinak eloszlási gyakorisága óvodában (1. tesztváltozat)

39. ábra. A korai numerikus készségek teszt személy-item térképe az óvodában

40. ábra. A korai numerikus készségek teszt első tesztváltozatának faktorstruktúrája óvodában

41. ábra. Az elemi számolás részteszt elörefelé számolást mérő feladatain elért átlagpontszám

42. ábra. Az óvodás gyermekek átlagteljesitényének eloszlása a korai numerikus készségek

teszt elsö tesztváltozatának résztesztjein

43. ábra. Az óvodás gyermekek átlagteljesitényének eloszlása a korai numerikus készségek teszt résztesztjein (1. tesztváltozat).

44. ábra. Az óvodás gyermekek a korai numerikus készségek és a tablet eszközhasználat teszteken elért teljesitményének összefüggései

45. ábra. A korai numerikus készségek teszt személy-item térképe az iskolában

46. ábra. A korai numerikus készségek teszt 6-dimenziós CFA-modellje (1. tesztváltozat) ... 106

47. ábra. Az első évfolyamos tanulók teljesitényének eloszlása a korai numerikus készségek teszten.....

48. ábra. Az elsö évfolyamos tanulók átlagteljesítményének eloszlása

a korai numerikus készségek teszt résztesztjein (1. tesztváltozat).

49. ábra. Az első évfolyamos tanulók a korai numerikus készségek és a számitógépes-egér használat teszteken elért teljesítménye....

50. ábra. Az itemek elkülönitésmutatóinak eloszlási gyakorisága óvodában (2. tesztváltozat)

51. ábra. A korai numerikus készségek teszt 2. változatának személy-item térképe az óvodában

52. ábra. A korai numerikus készségek teszt második tesztváltozatának faktor struktúrája óvodába

53. ábra. Az óvodás gyermekek teljesitényének eloszlása a korai numerikus készségek teszt második tesztváltozatának résztesztjein

54. ábra. Átlagteljesitmények eloszlása a korai numerikus készségek teszt résztesztjein az óvodában (2. tesztváltozat).

55. ábra. Az elsö évfolyamos tanulók a korai numerikus készségek és a számitógépes-egér használat teszteken elért teljesitménye. 
56. ábra. A korai numerikus készségek teszt személy-item térképe az óvodai validációs mérésen.

57. ábra. A korai numerikus készségek teszten elért teljesitmények eloszlása az óvodai és iskolai méréseken

58. ábra. Tanulói átlagteljesítmények összefüggése a korai numerikus készségek teszten és a matematika teszten

59. ábra. 1. modell: A korai numerikus készségek és a matematika teljesitmény közvetlen kapcsolata.

60. ábra. 2. modell: A korai numerikus készségek és a matematika három dimenziójának kapcsolata.

61. ábra. 3. modell: A korai numerikus készségek összetevőinek és az iskolai matematika teljesitmény kapcsolata 


\section{TÁBLÁZATOK JEGYZÉKE}

1. táblázat. A vizsgált számolási készségeket mérő tesztek fő jellemzői ...............................21

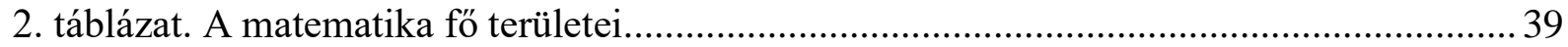

3. táblázat. A korai numerikus készségek teszt kidolgozásával és méréseivel kapcsolatos

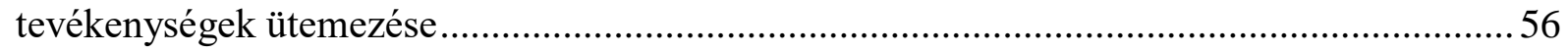

4. táblázat. Vizsgálataink mintái - nemek szerinti megoszlások, átlagélekor ..........................59

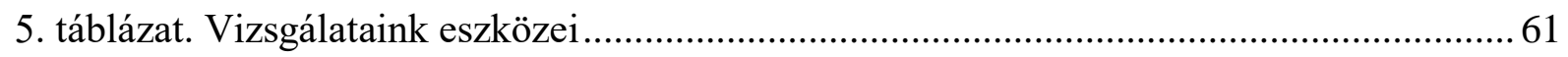

6. táblázat. A matematika a teszt dimenzióinak megbízhatósága .......................................... 76

7. táblázat. Számítógépes-egér használat és Tablet eszközhasználat tesztváltozatok itemeinek száma, megbízhatósága és a tanulók átlagos teljesítménye .............................................. 78

8. táblázat. A korai numerikus készségek teszt és résztesztjeinek megbízhatósága az óvodában

9. táblázat. Az első tesztváltozat és résztesztjeinek korrelációs együtthatói az óvodában........92

10. táblázat. A korai numerikus készségek első tesztváltozat megerősítő faktorelemzésének

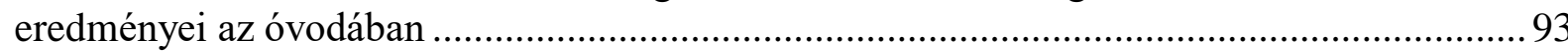

11. táblázat. CFA-modellek Khi-négyzet különbözőségi próbáinak eredményei az óvodában

12. táblázat. Az óvodás korú gyermekek korai numerikus készségek teszten és a részteszteken

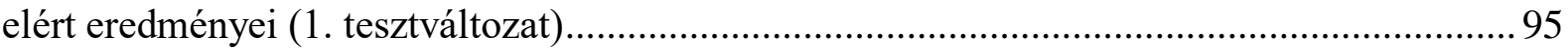

13. táblázat. A teszt és résztesztjeinek eloszlásmutatói óvodás korosztályban (1. tesztváltozat) .98

14. táblázat. A teszt és résztesztjeinek megbízhatósága és a tanulók átlagteljesítménye ...... 100

15. táblázat. A korai numerikus készségek teszt itemeinek teljes teszthez és résztesztekhez kapcsolódó elkülönítésmutatói, és az itemek prediktív validitása 101

16. táblázat. Az első tesztváltozat és résztesztjeinek korrelációs együtthatói első évfolyamon

17. táblázat. A CFA-modellek illeszkedésmutatói az iskolai mérésen 105

18. táblázat. CFA-modellek Khi-négyzet különbözőségi próbáinak eredményei az óvodában

19. táblázat. Az első évfolyamos tanulók korai numerikus készségek teszten és a részteszteken elért eredményei (1. tesztváltozat).

20. táblázat. A teszt és résztesztjeinek eloszlásmutatói első évfolyamon (1. tesztváltozat) .. 108 21. A korai numerikus készségek teszt és résztesztjeinek megbízhatósága az óvodában ( 2 . tesztváltozat).

22. táblázat. A második tesztváltozat és résztesztjeinek korrelációs együtthatói az óvodában

23. táblázat. A korai numerikus készségek teszt megerősítő faktorelemzésének eredményei 
24. táblázat. CFA-modellek Khi-négyzet különbözőségi próbáinak eredményei az óvodában

25. táblázat. Az óvodás korú gyermekek korai numerikus készségek teszten és a részteszteken

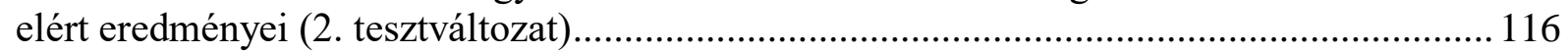

26. táblázat. A teszt és résztesztjeinek eloszlásmutatói óvodában (2. tesztváltozat) ............. 118

27. táblázat. Az óvodai validációs mérésen alkalmazott online mérőeszközök eredményei . 120

28. táblázat. Az óvodai validációs mérésen alkalmazott szemtől szembeni mérőeszközök

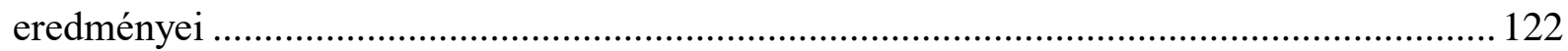

29. táblázat. Az online és a szemtől szembeni mérőeszközök összefüggései

30. táblázat. A DIFER elemi számolási készség teszt és korai numerikus készségek teszt résztesztjeinek összefüggései

31. táblázat. A korai numerikus készségek teszt és résztesztjeinek megbízhatósága az óvodában és az iskolában (1. tesztváltozat).

32. táblázat. A korai numerikus készségek teszten és résztesztjein elért eredmények az óvodában és első évfolyamon.

33. táblázat. Nemek közötti különbségek a korai numerikus készségek teszten és résztesztjein az óvodában (1. tesztváltozat)

34. táblázat. Nemek közötti különbségek a korai numerikus készségek teszten és résztesztjein az óvodában (2. tesztváltozat)

35. táblázat. Nemek közötti különbségek a korai numerikus készségek teszten és résztesztjein az iskolában (1. tesztváltozat)

36. táblázat. A matematika teszt és résztesztjeinek megbízhatósága és a tanulók

átlagteljesítménye

37. táblázat. A korai numerikus készségek teszt és résztesztjeinek megbízhatósága és a tanulók átlagteljesítménye.

38. táblázat. A DIFER elemi számolási készség teszt és korai numerikus készségek teszt résztesztjeinek összefüggései

39. táblázat. A SEM-modellek illeszkedésmutatói

\section{MELLÉKLETEK JEGYZÉKE}

1. Melléklet. Korai numerikus készségek teszt - 1. tesztváltozat ....................................... 166

2. Melléklet. Korai numerikus készségek teszt - 2. tesztváltozat ......................................... 185

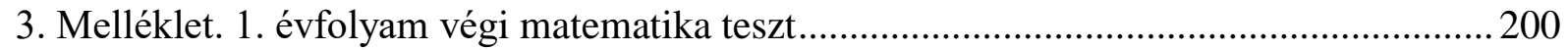

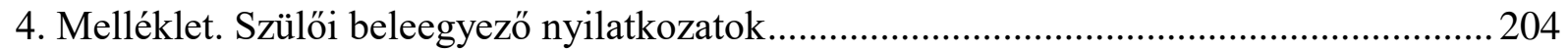

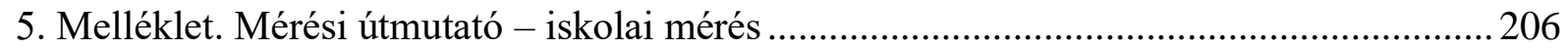

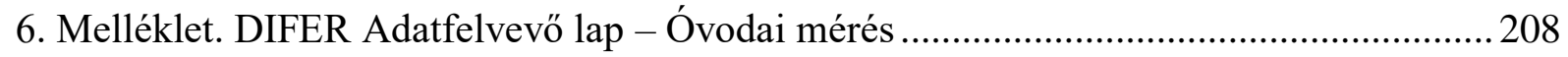

7. Melléklet. Reliabilitás-vizsgálatok eredményei - elkülönítésmutatók ...............................209 


\section{MELLÉKLETEK}

1. Melléklet. Korai numerikus készségek teszt - 1. tesztváltozat

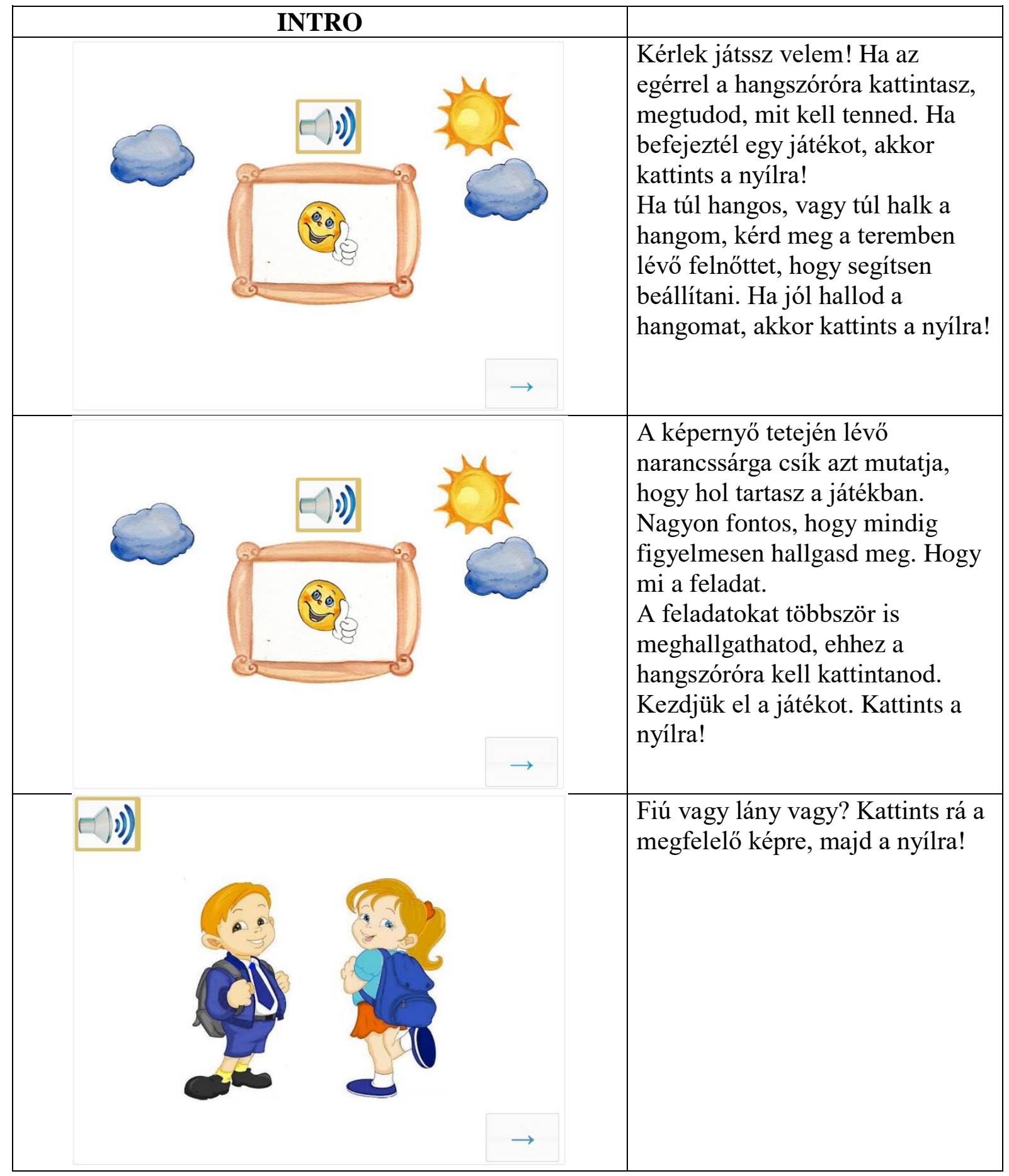




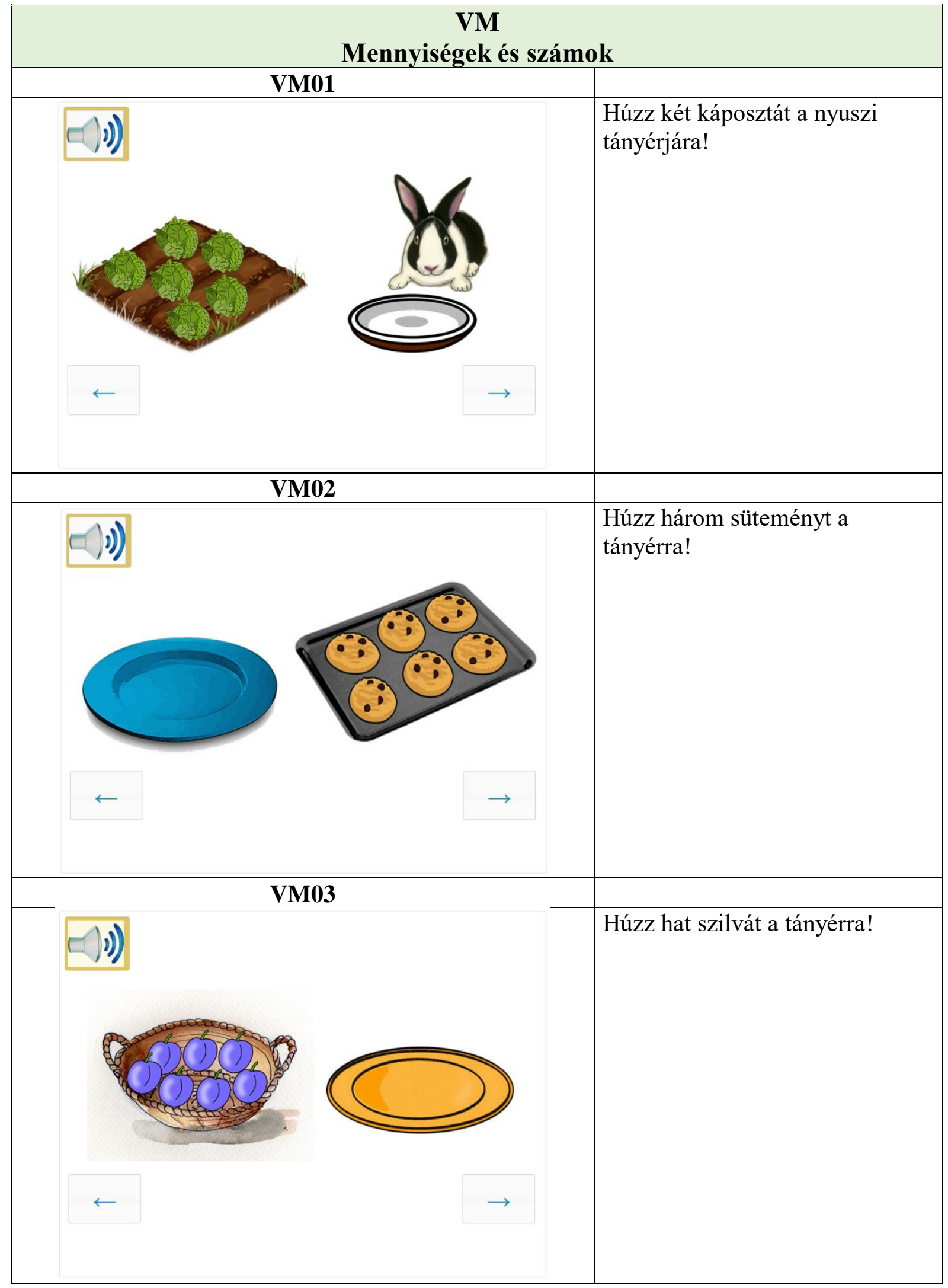




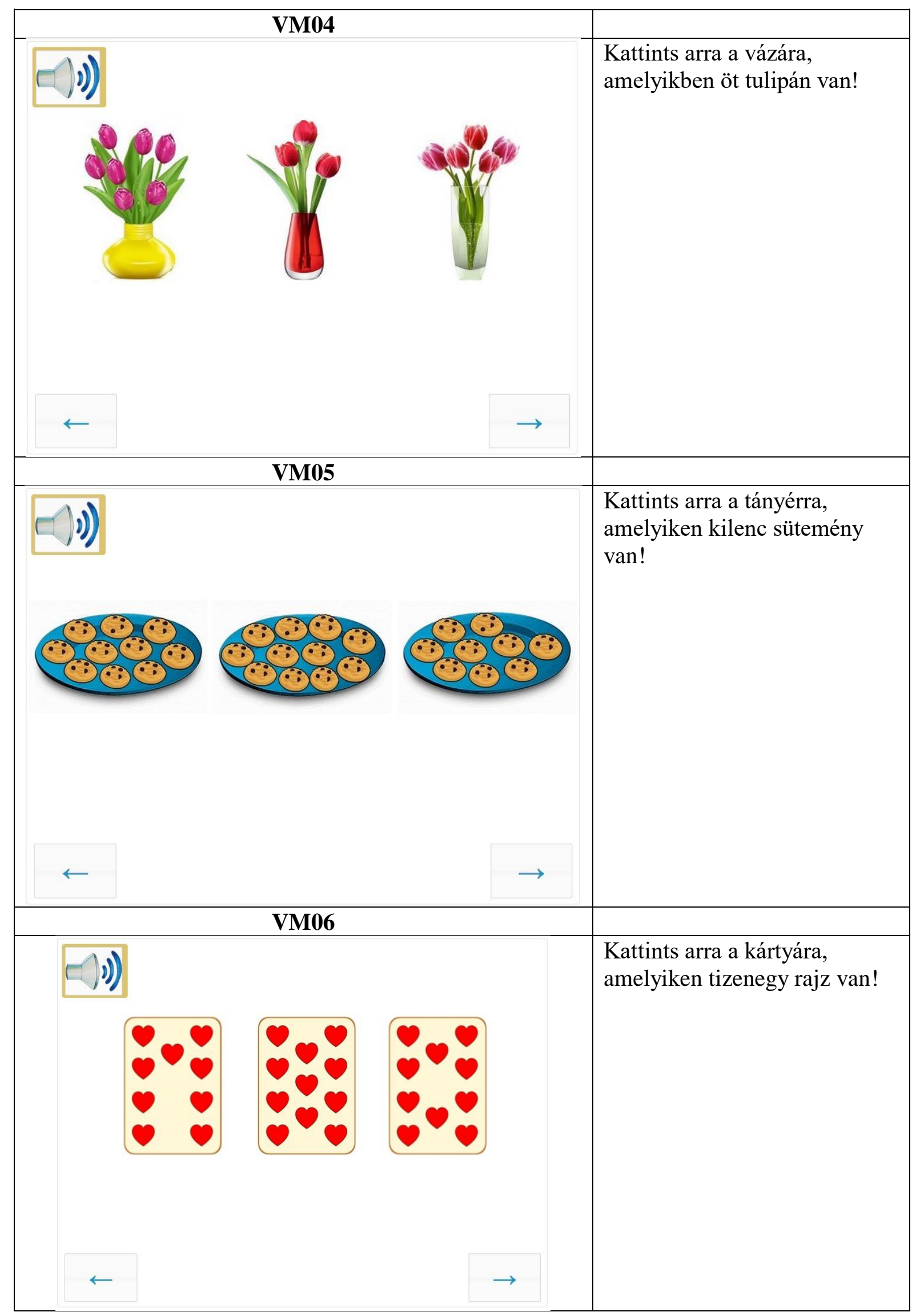




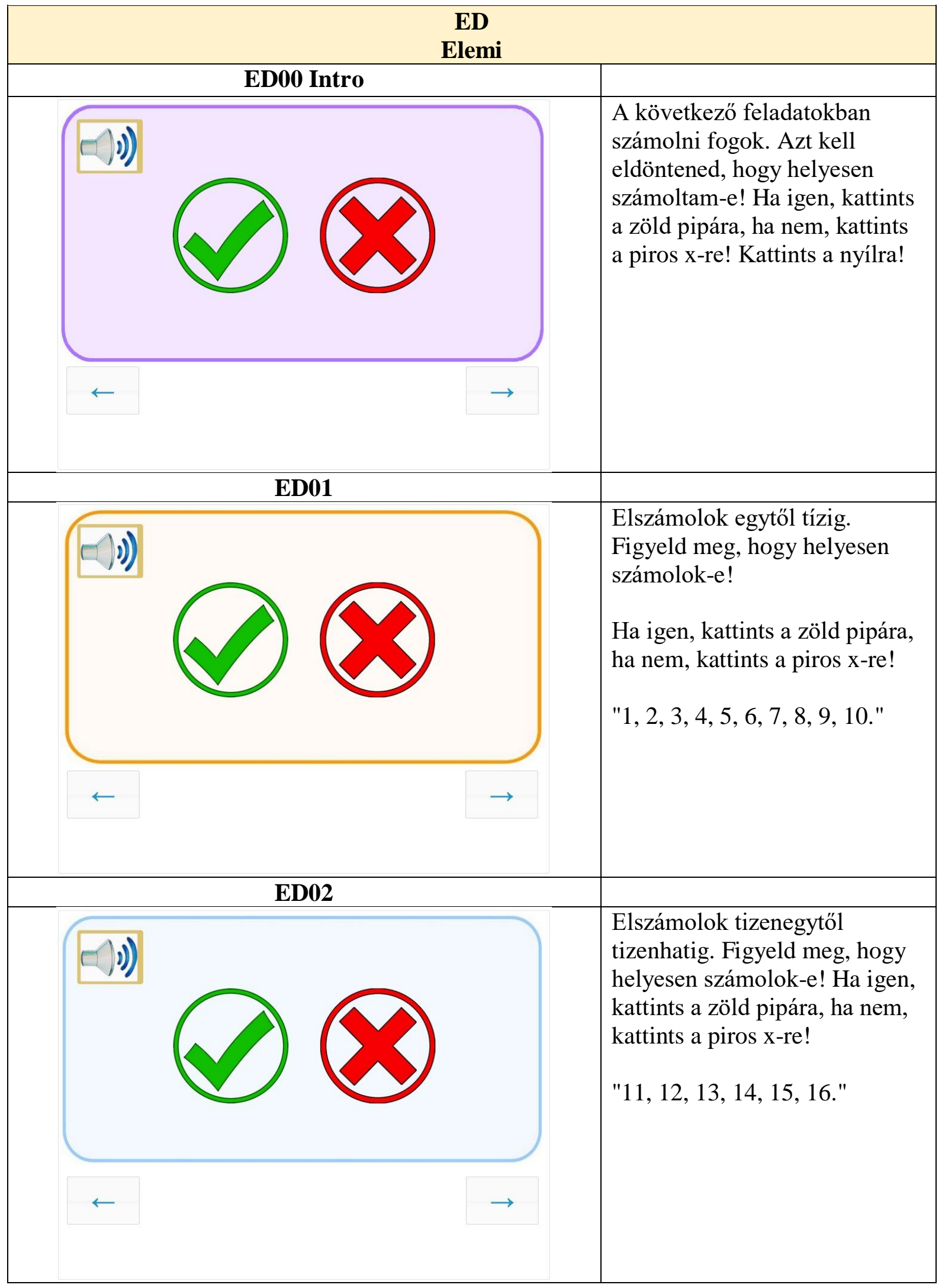




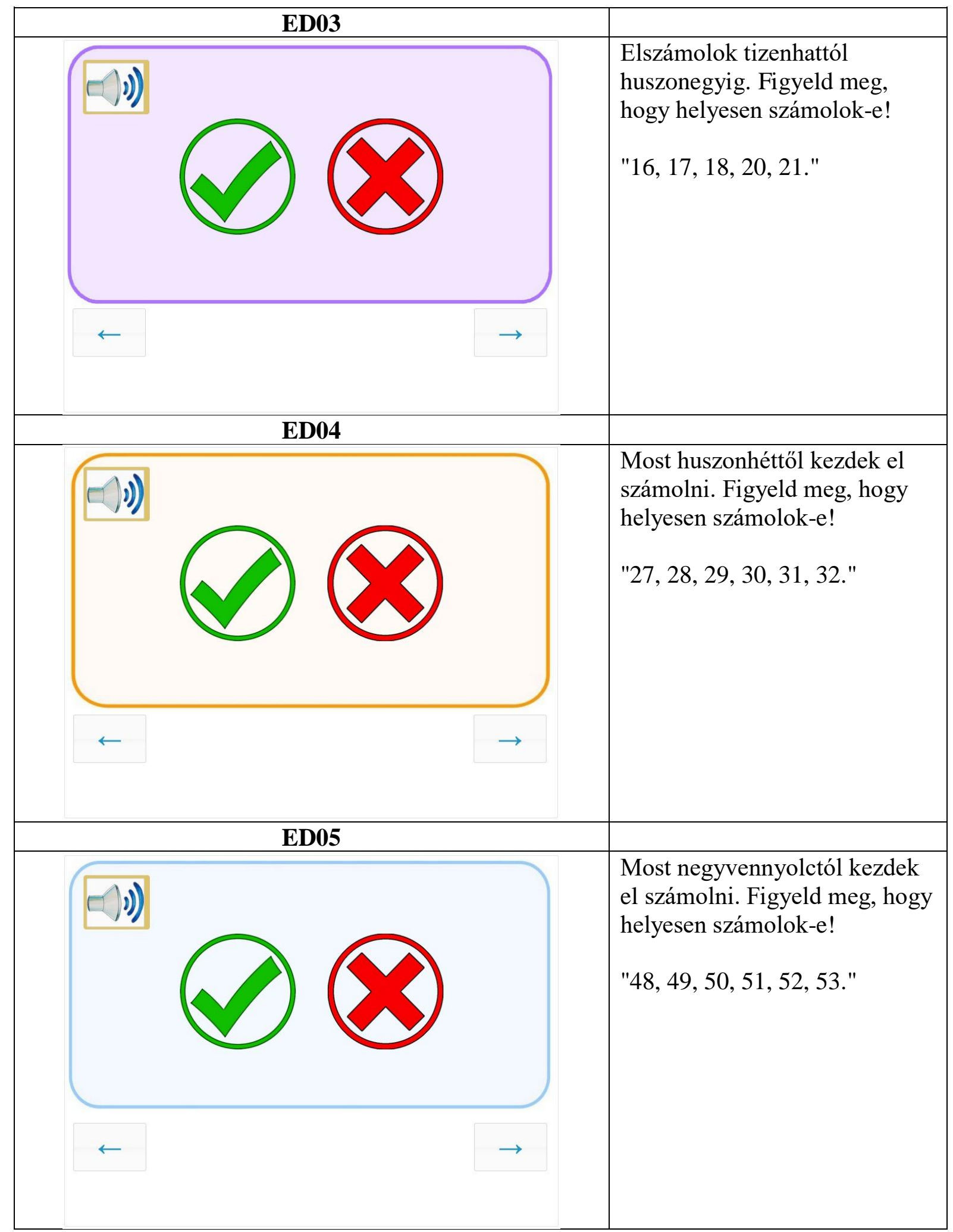




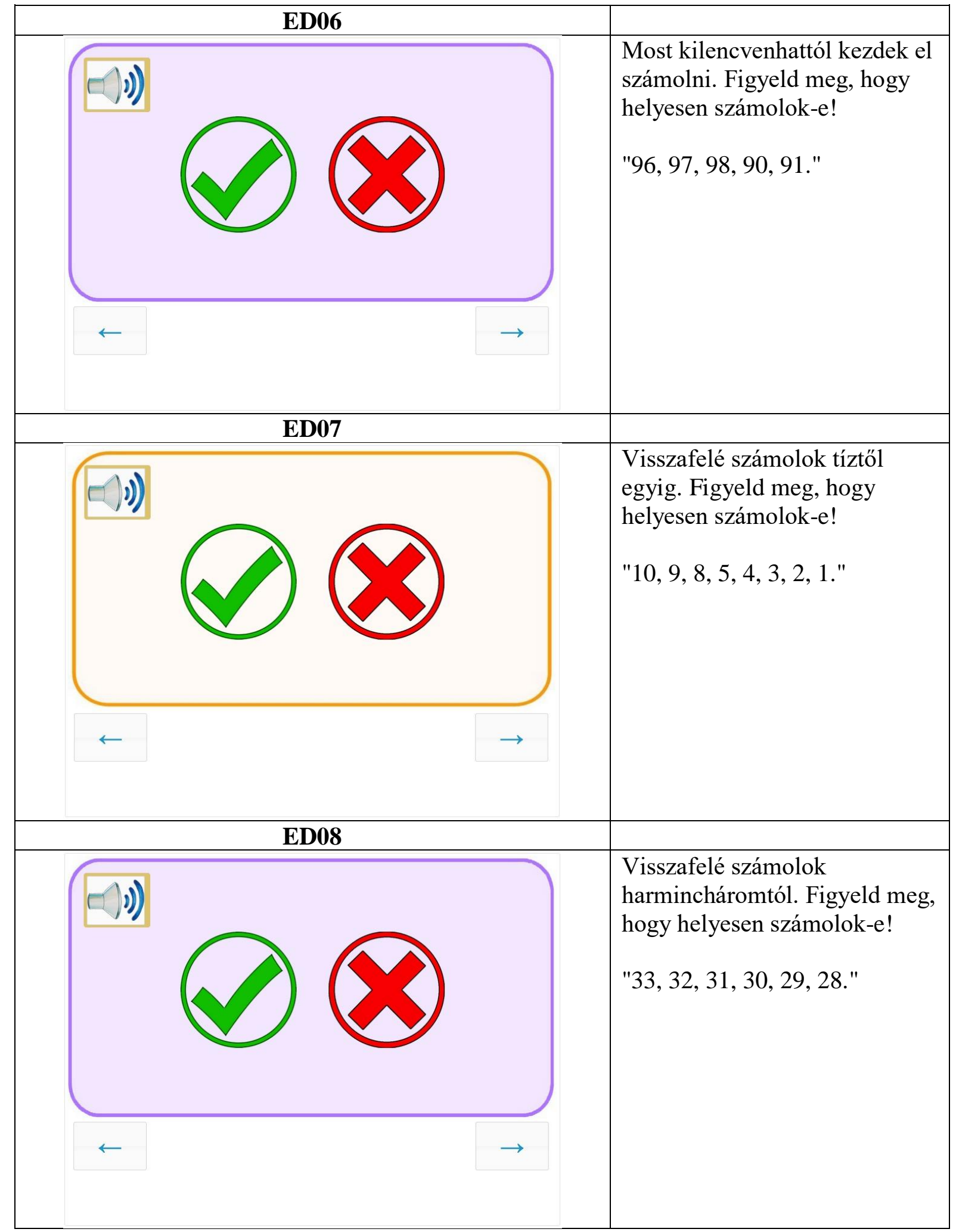




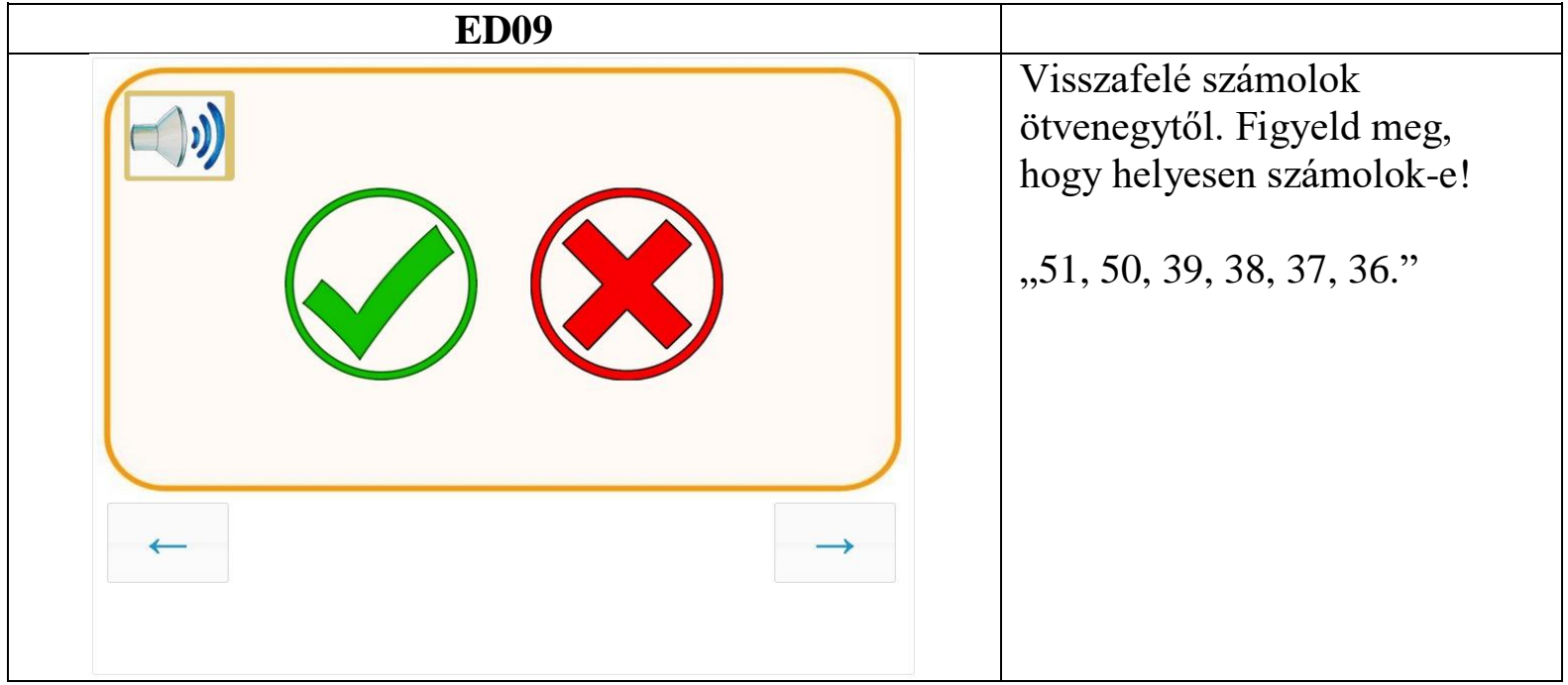

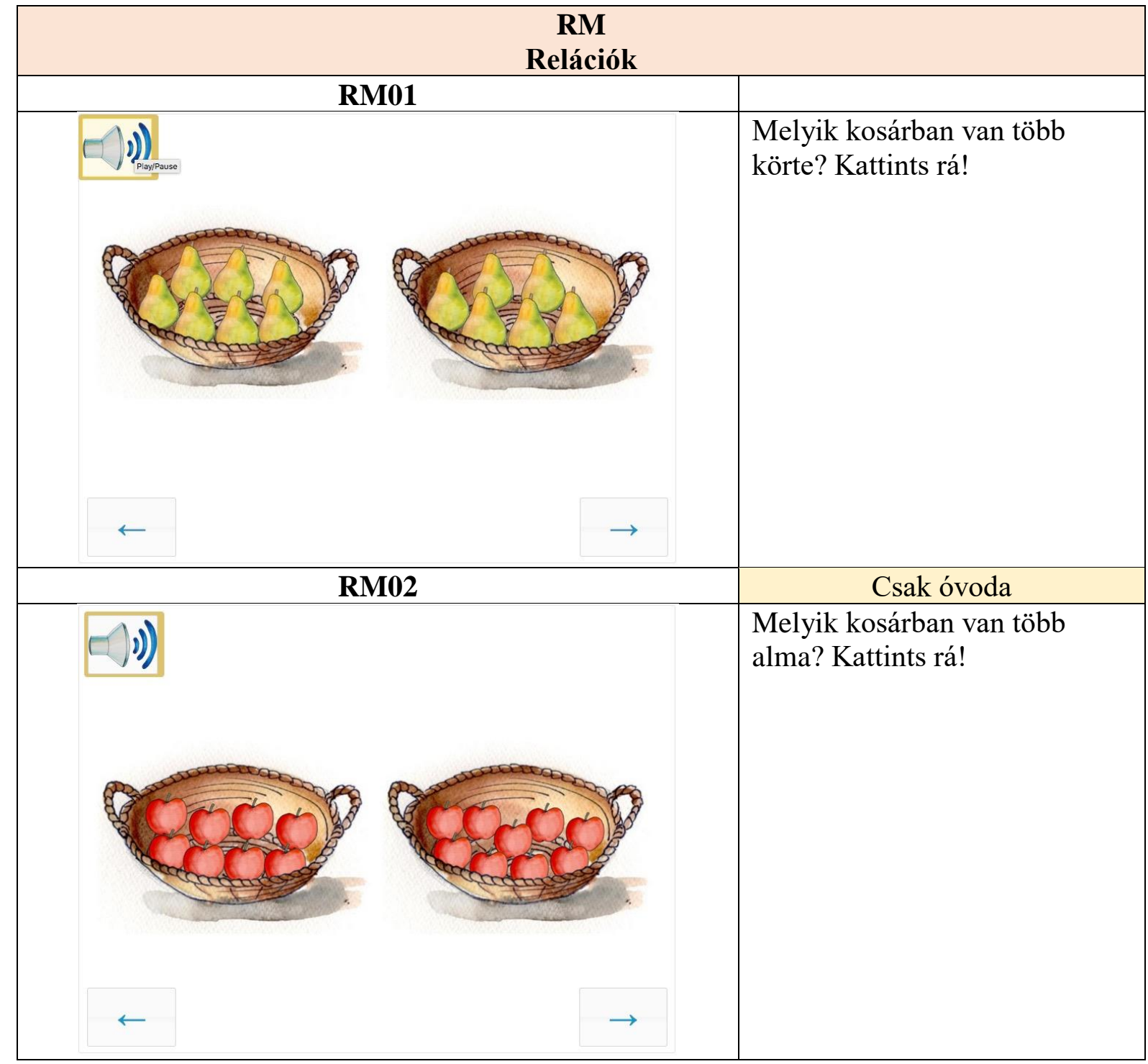




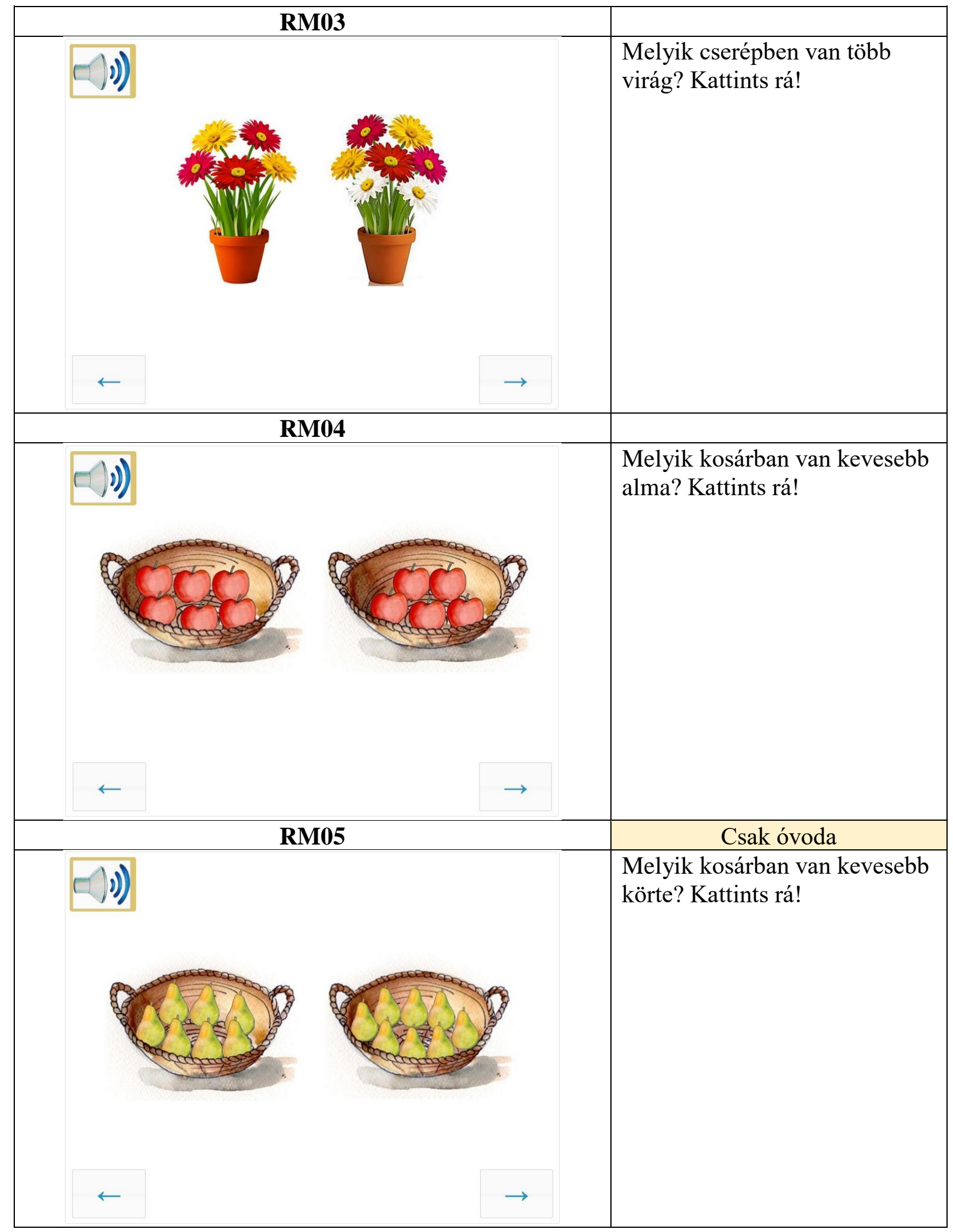




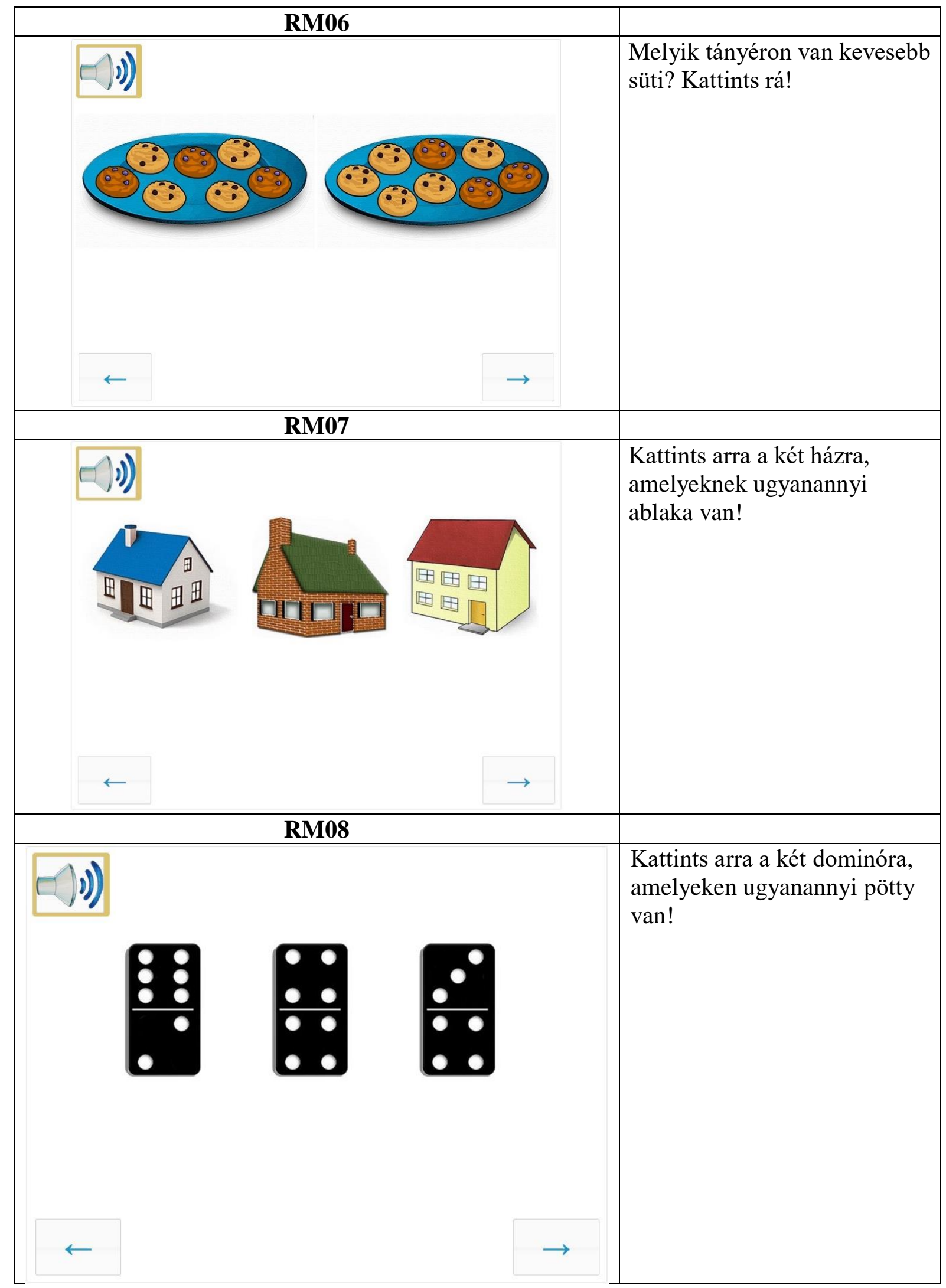




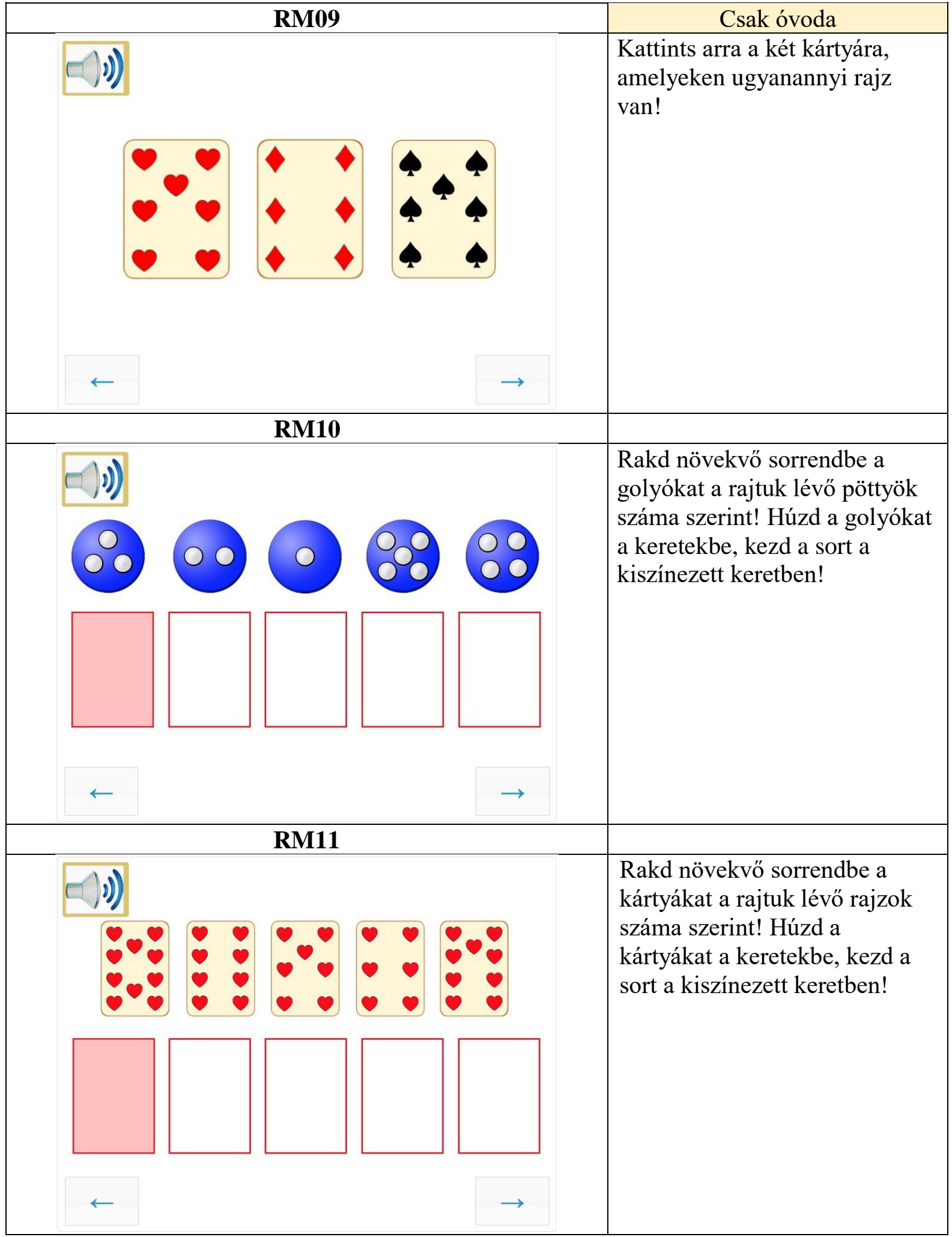




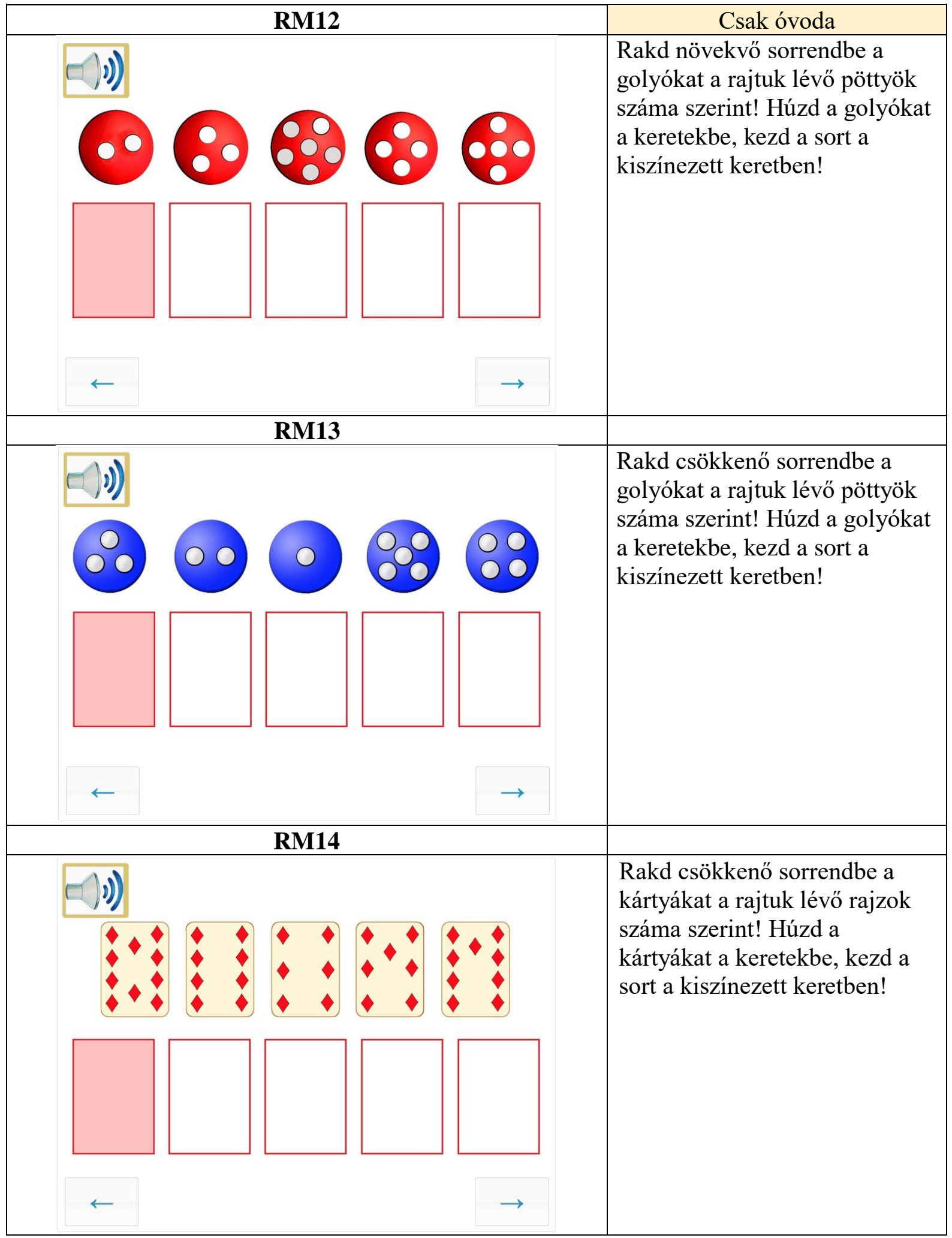




\begin{tabular}{|c|c|c|}
\hline \multicolumn{2}{|c|}{ RM15 } & \multirow[b]{2}{*}{\begin{tabular}{l}
\multicolumn{1}{c}{ Csak óvoda } \\
Rakd csökkenő sorrendbe a \\
golyókat a rajtuk lévő pöttyök \\
száma szerint! Húzd a golyókat \\
a keretekbe, kezd a sort a \\
kiszínezett keretben!
\end{tabular}} \\
\hline (D)) & & \\
\hline$\leftarrow$ & $\rightarrow$ & \\
\hline
\end{tabular}

\begin{tabular}{|l|l|}
\hline \multicolumn{3}{c|}{ OM Elemi múveletvégzés } \\
\hline \multicolumn{3}{|c|}{ OM01 } & $\begin{array}{l}\text { A kosárban most egy alma van, } \\
\text { húzz még annyi almát a } \\
\text { kosárba, hogy összesen három } \\
\text { legyen benne! }\end{array}$ \\
\hline
\end{tabular}




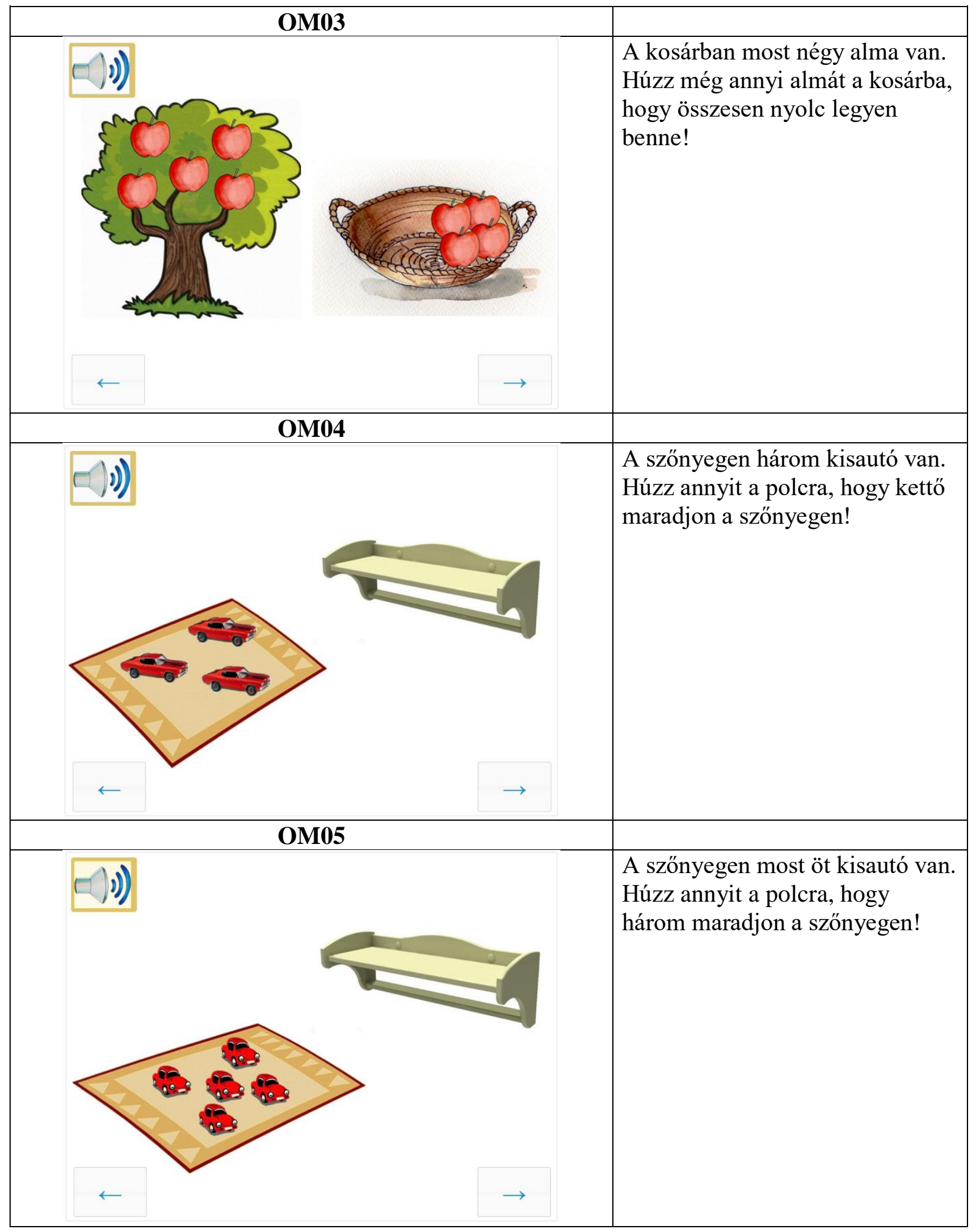




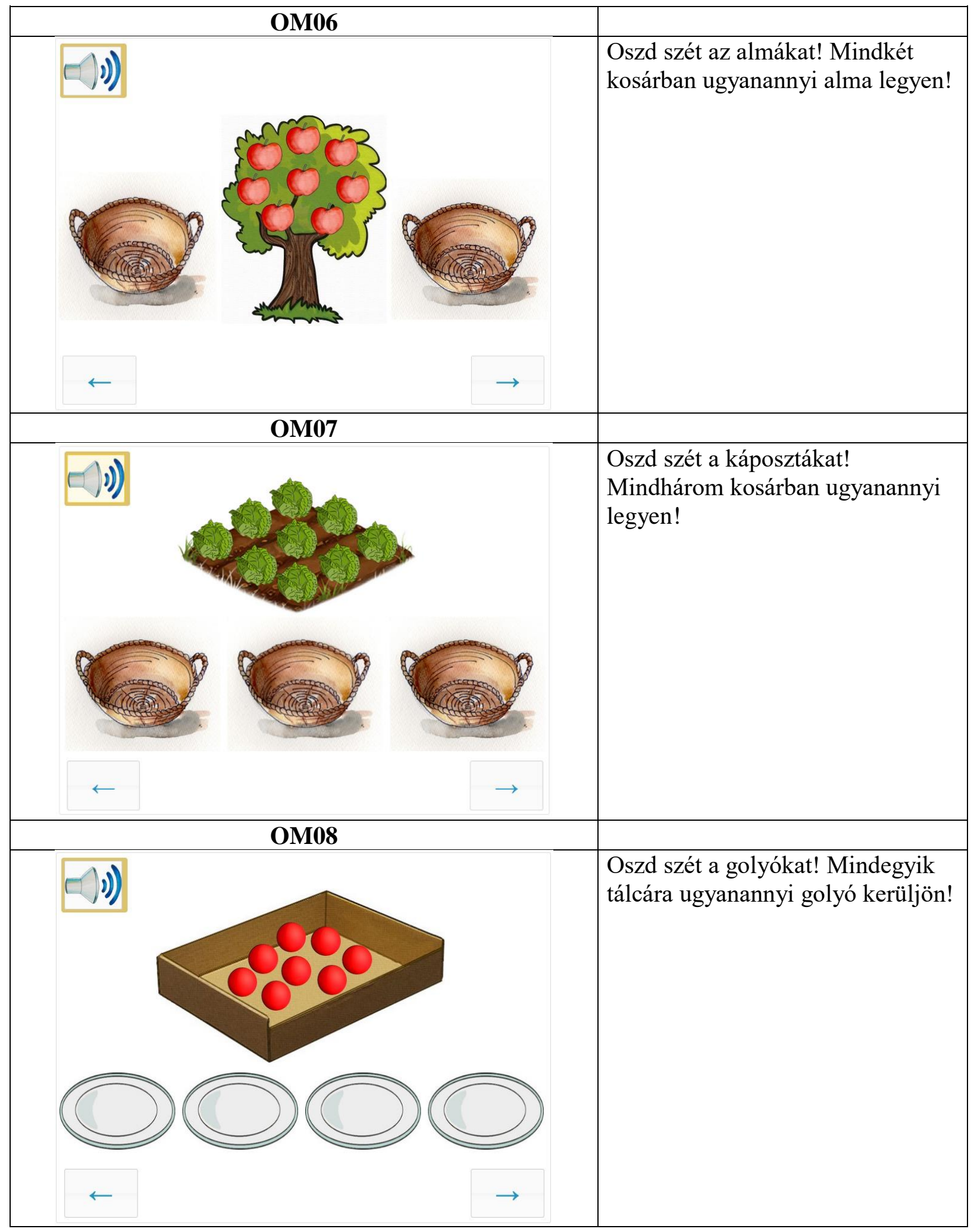




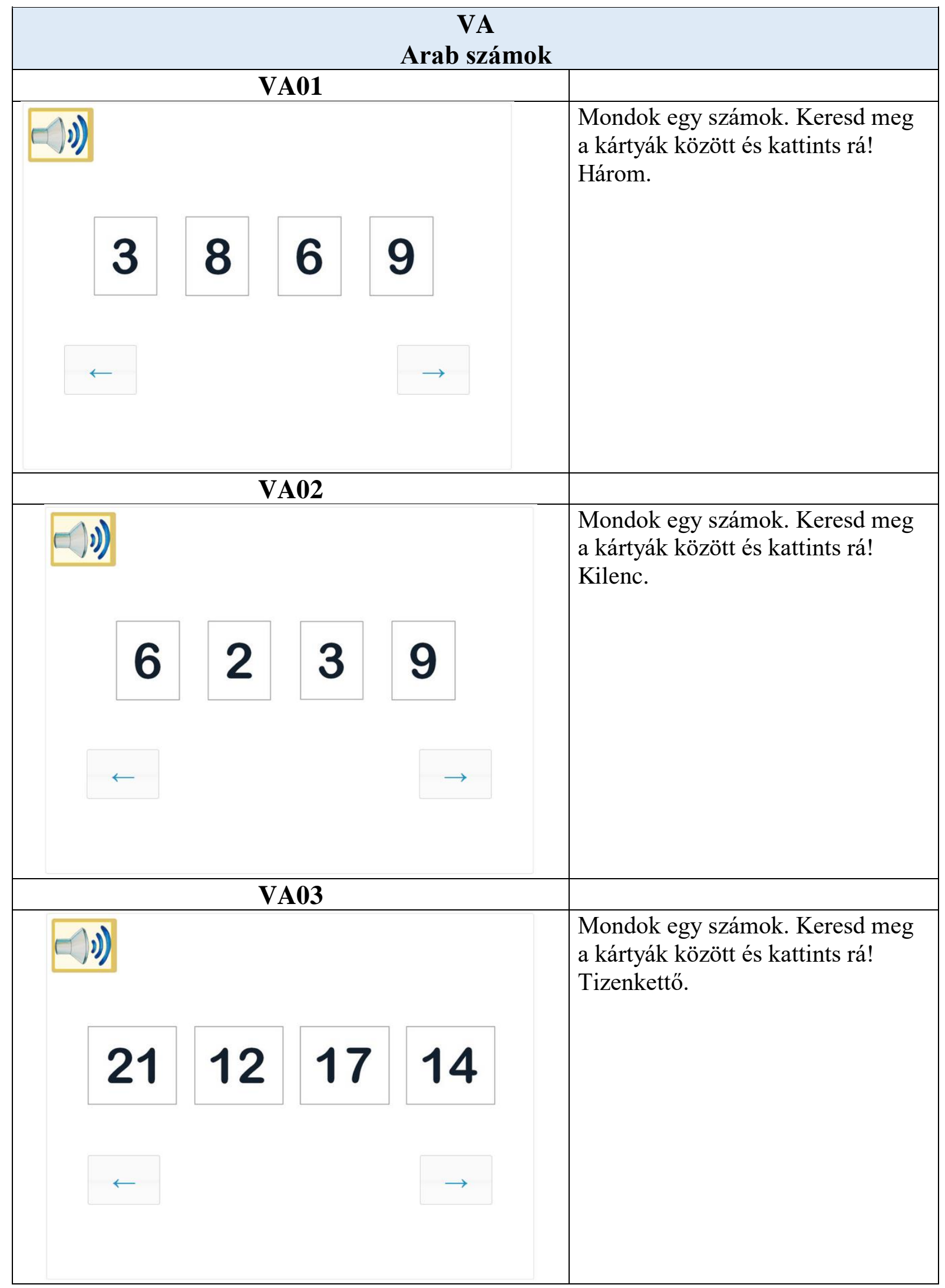




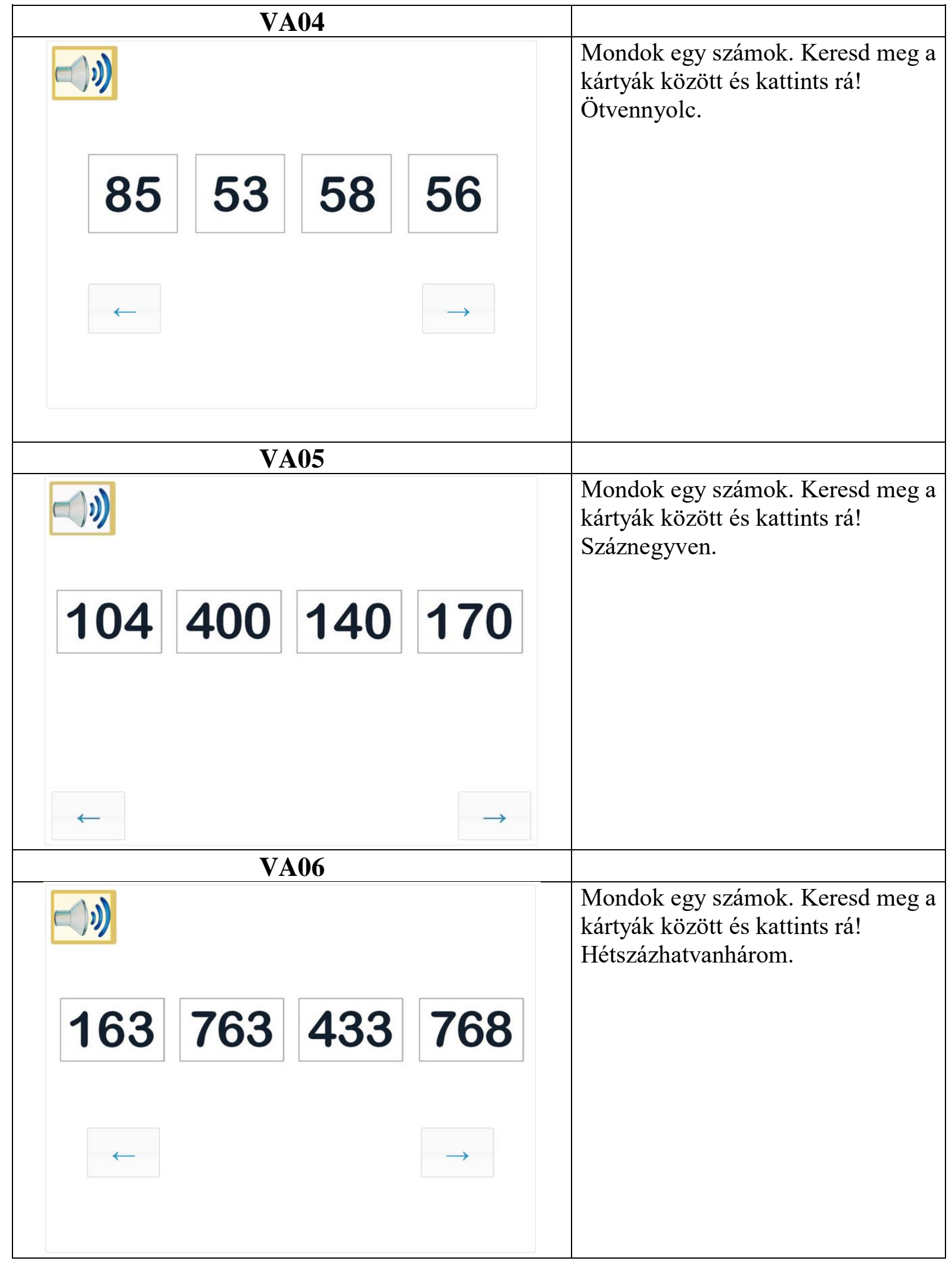




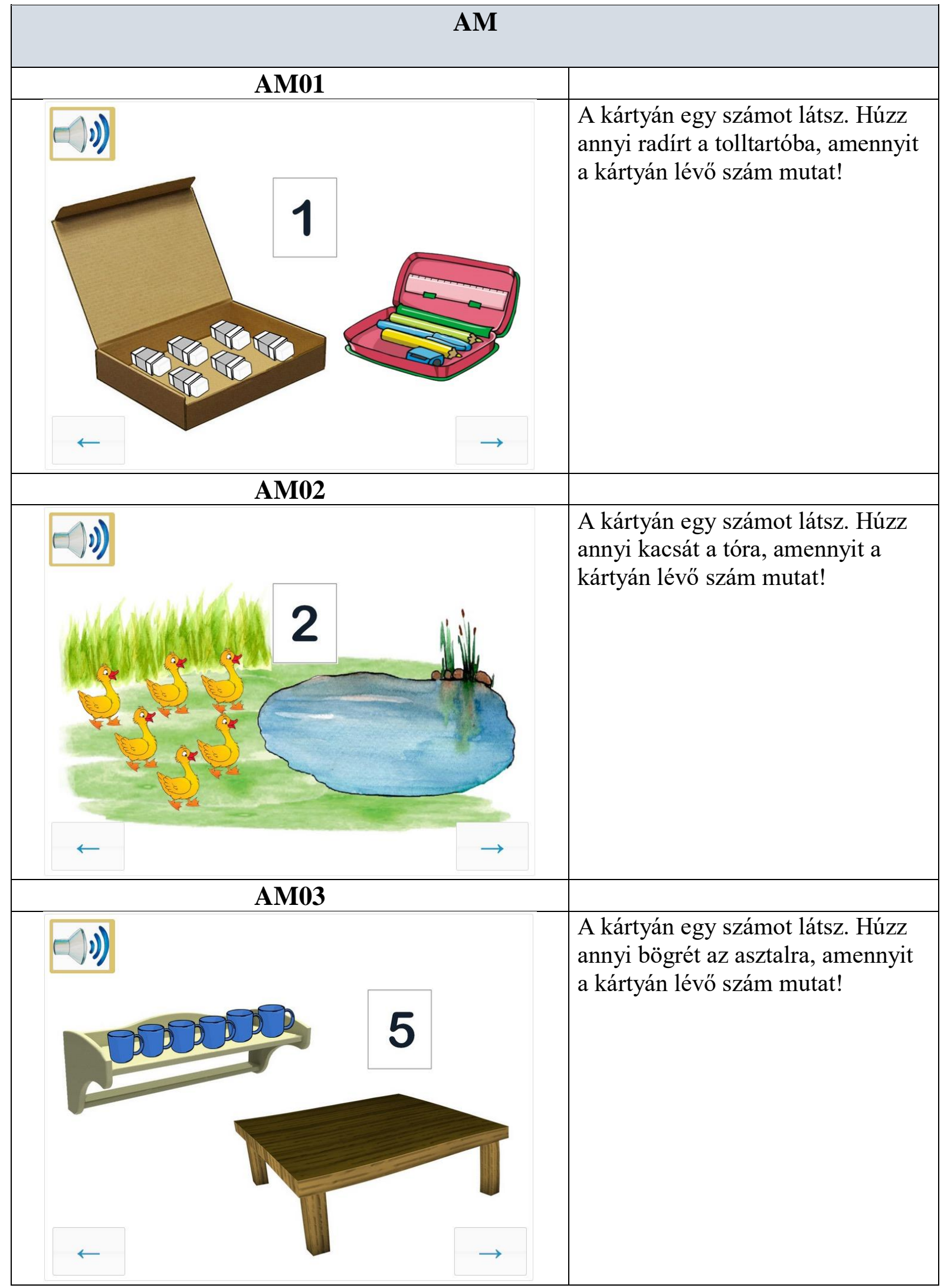




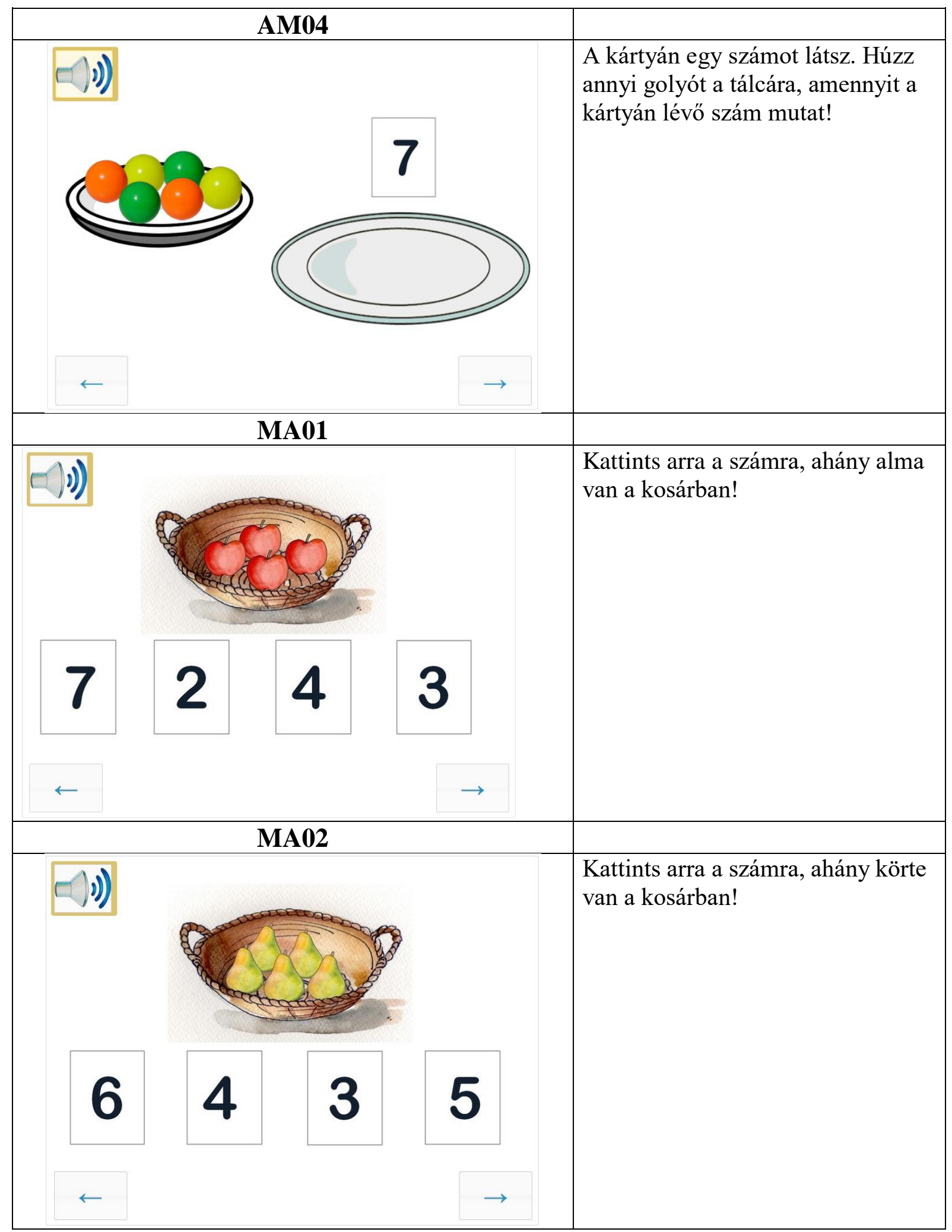




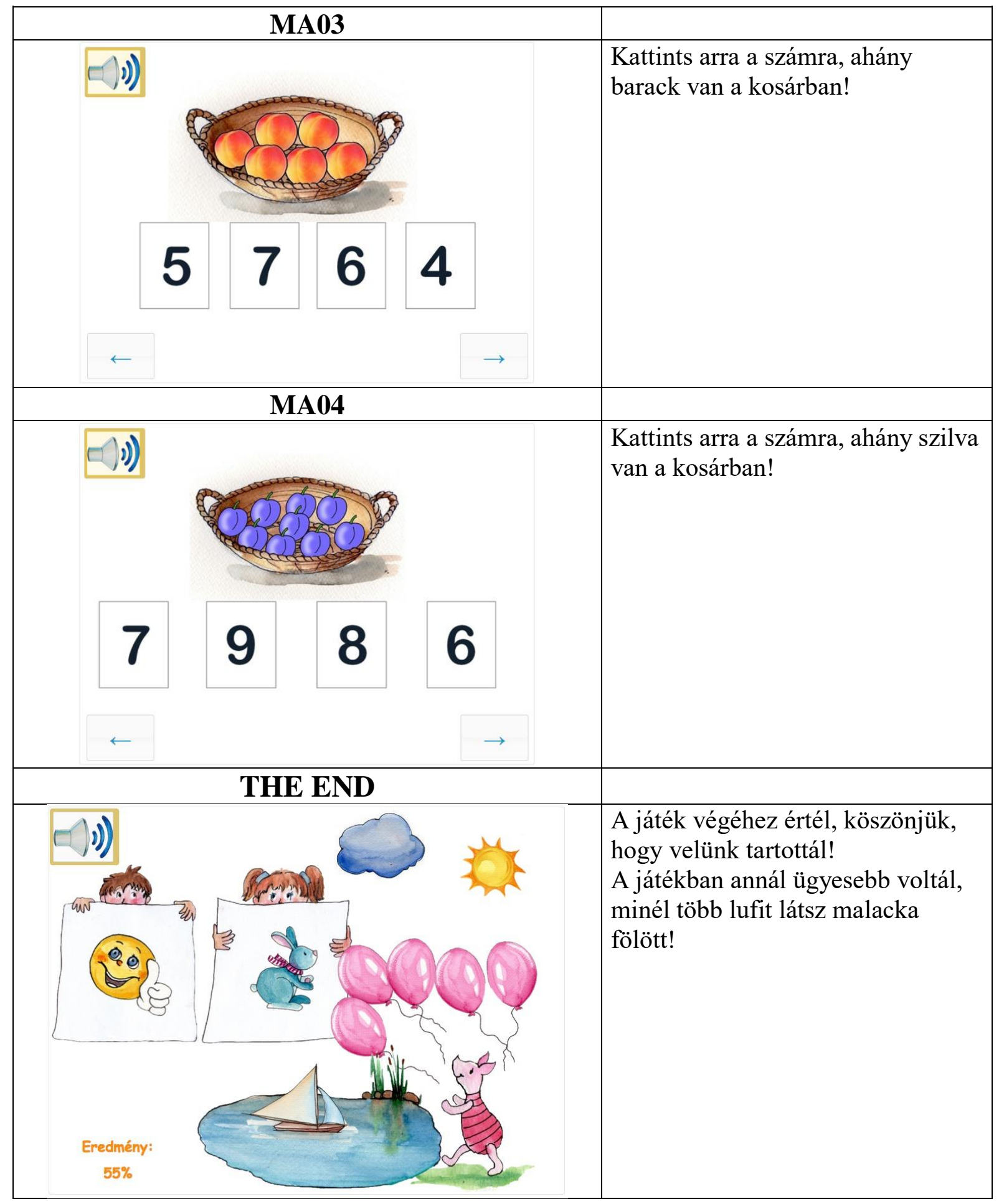




\section{Melléklet. Korai numerikus készségek teszt - 2. tesztváltozat}

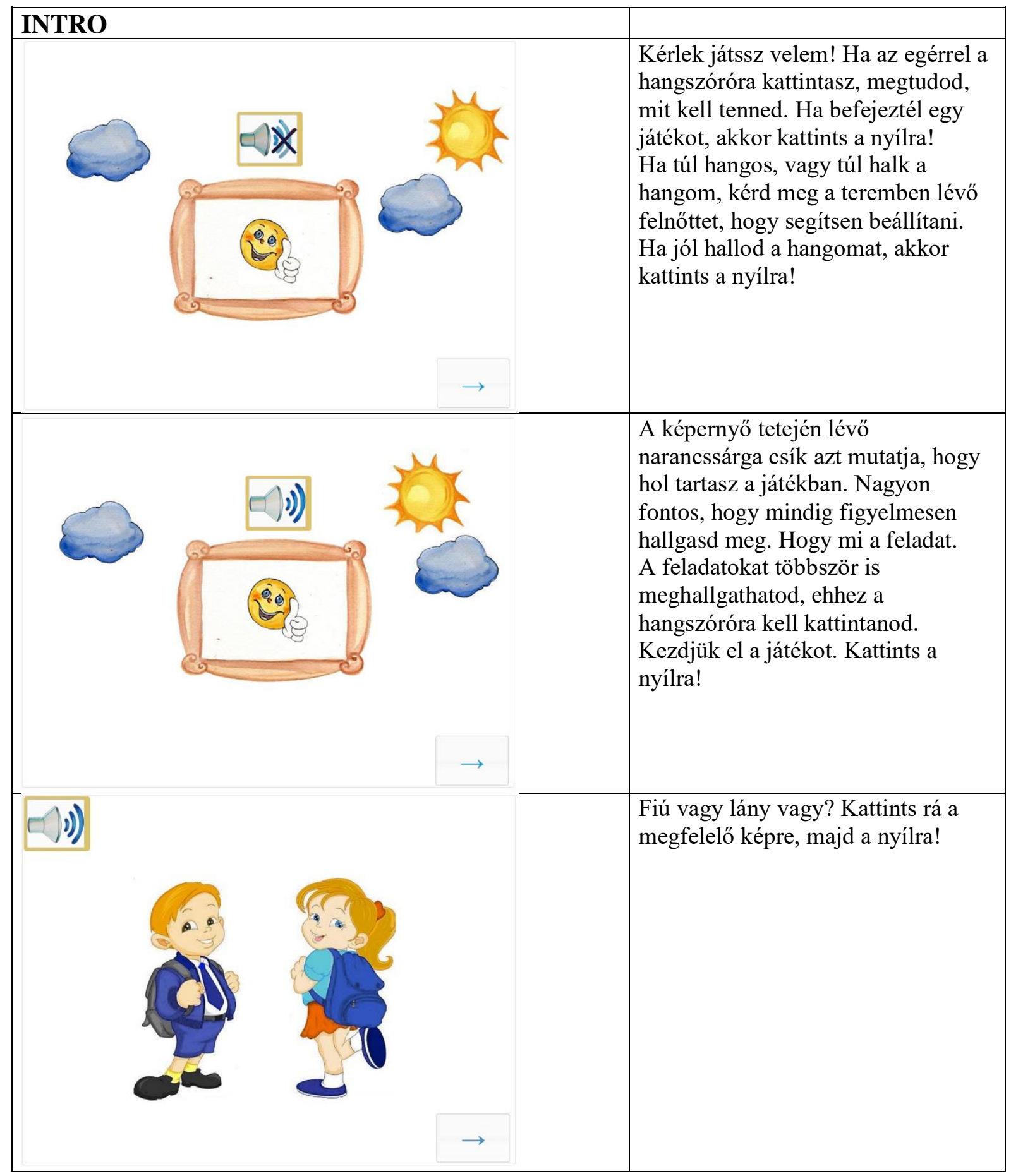




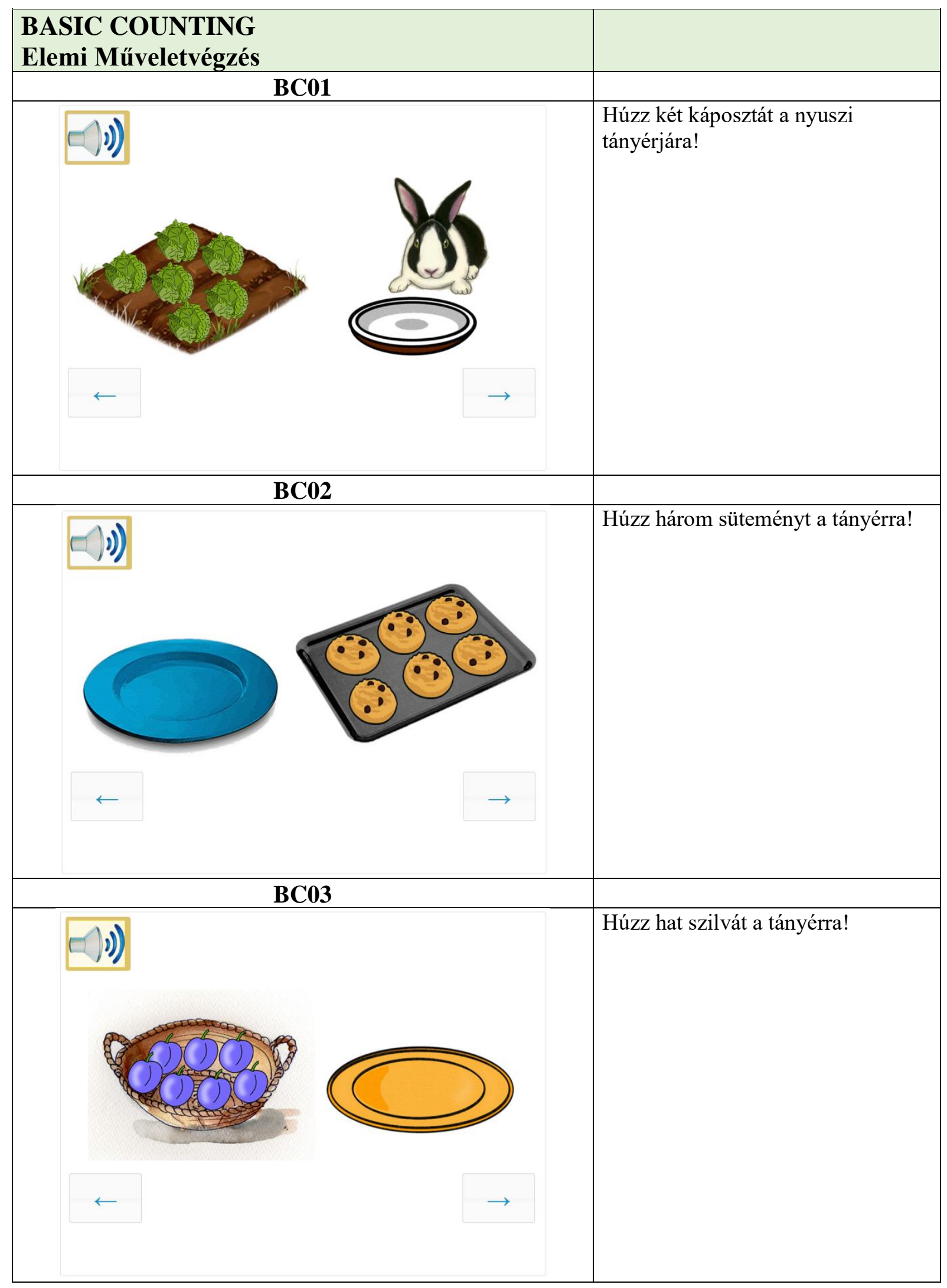




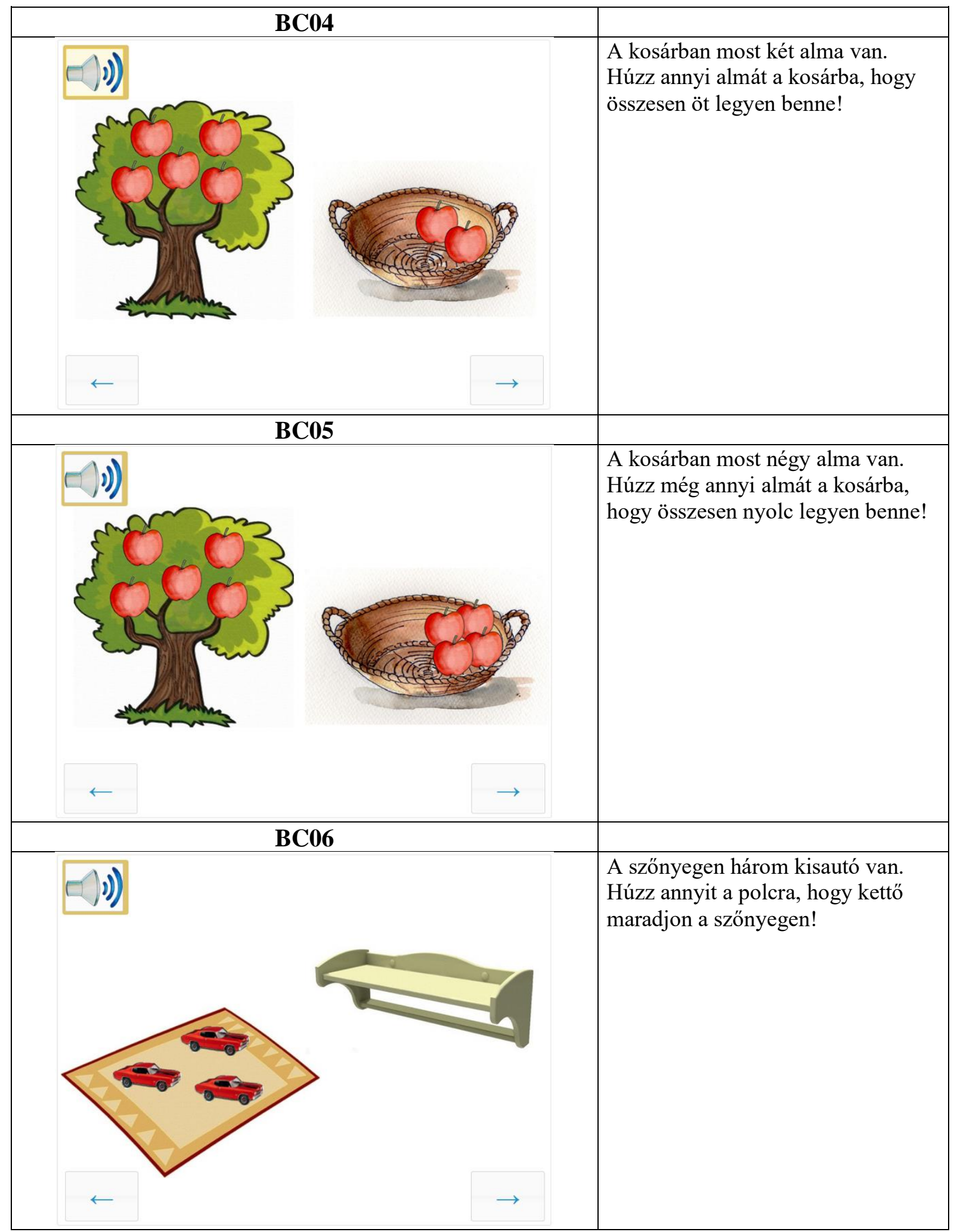




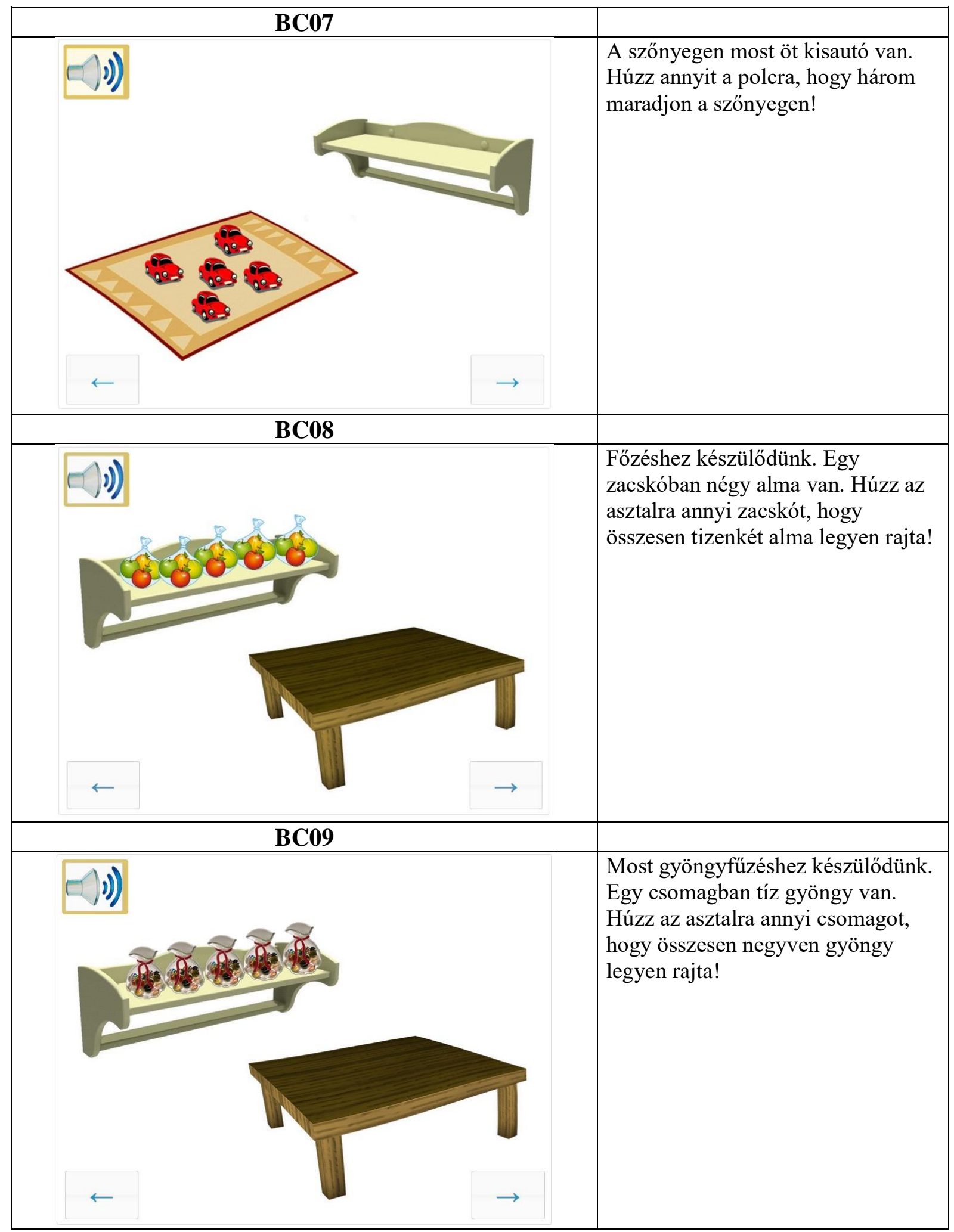




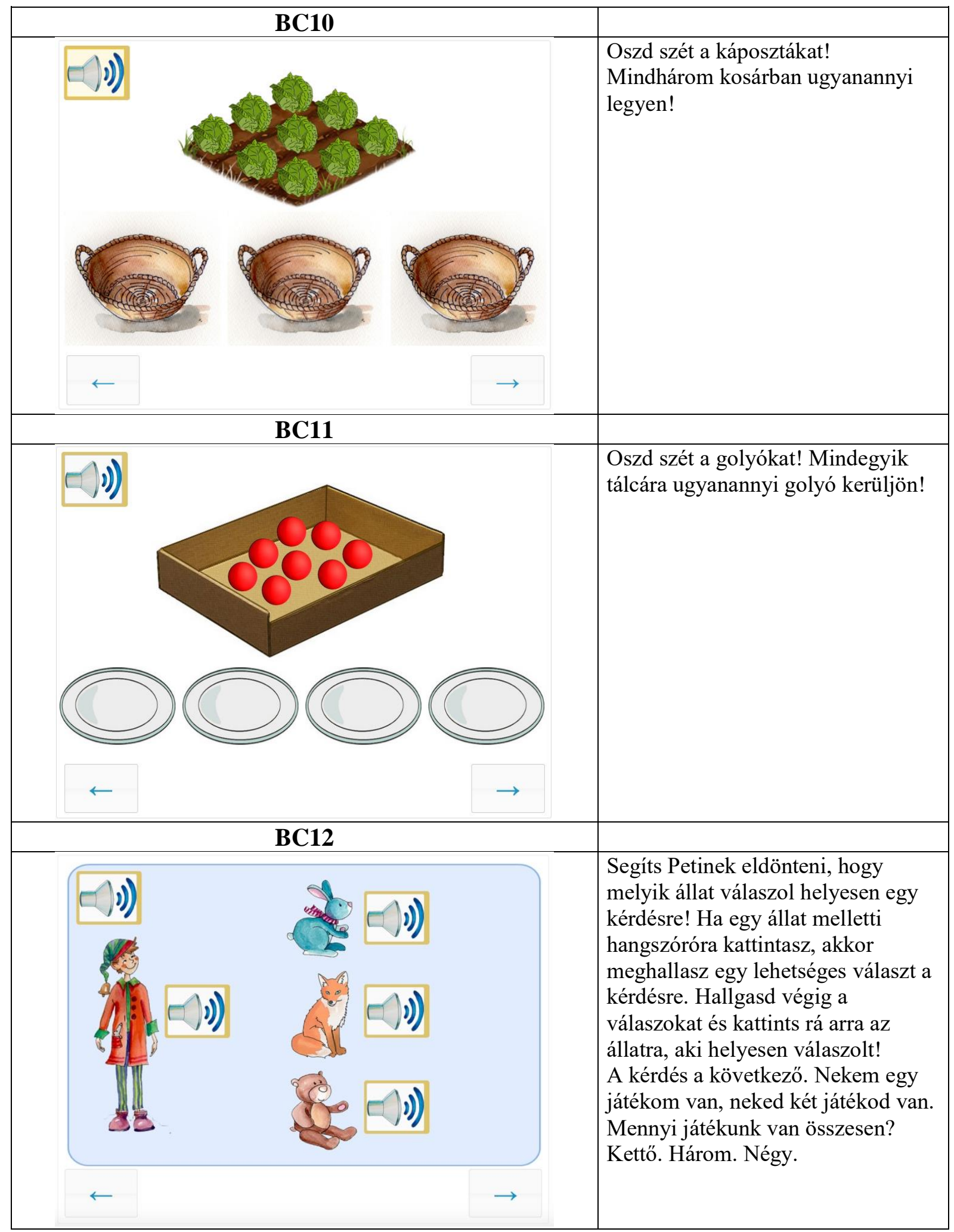




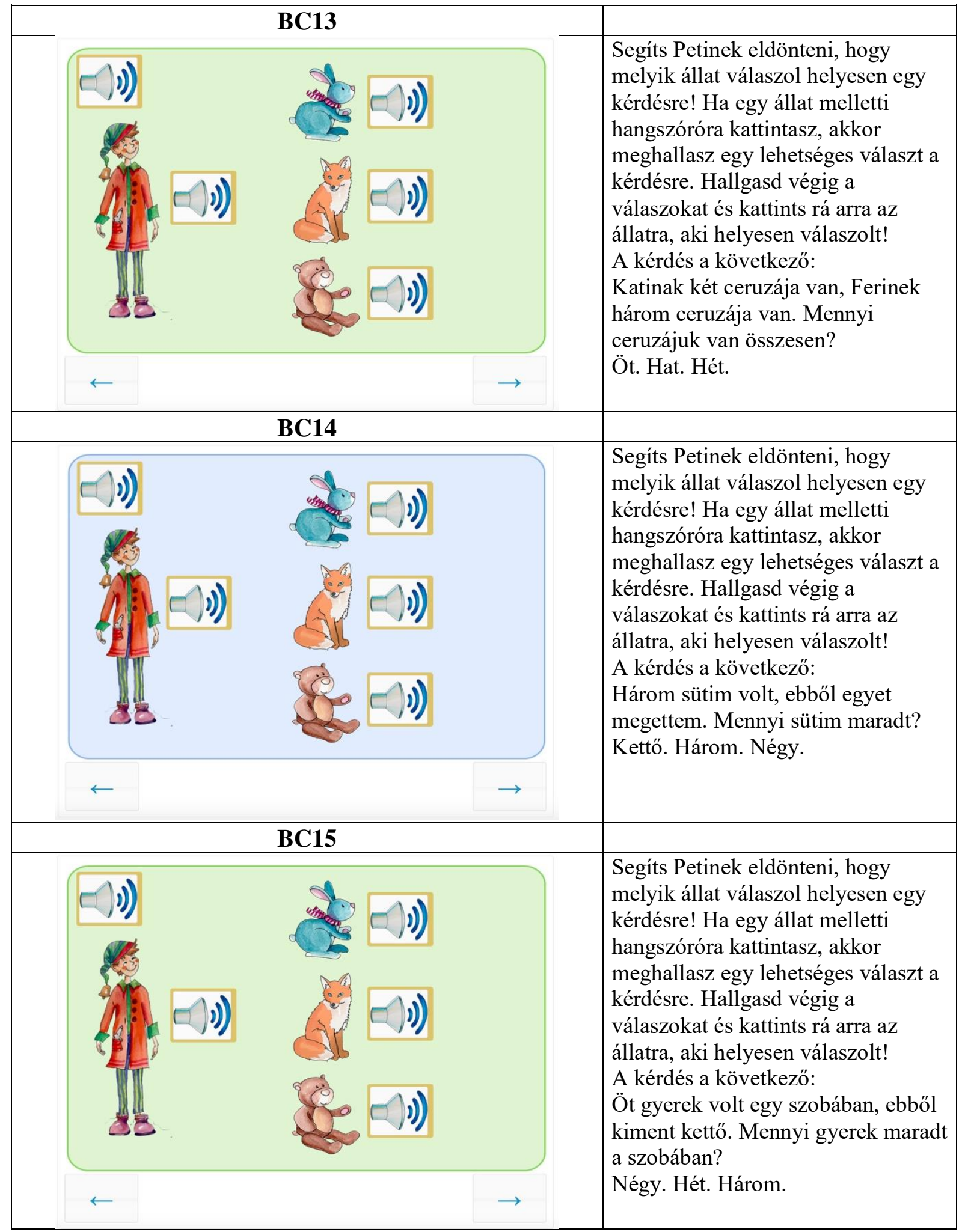




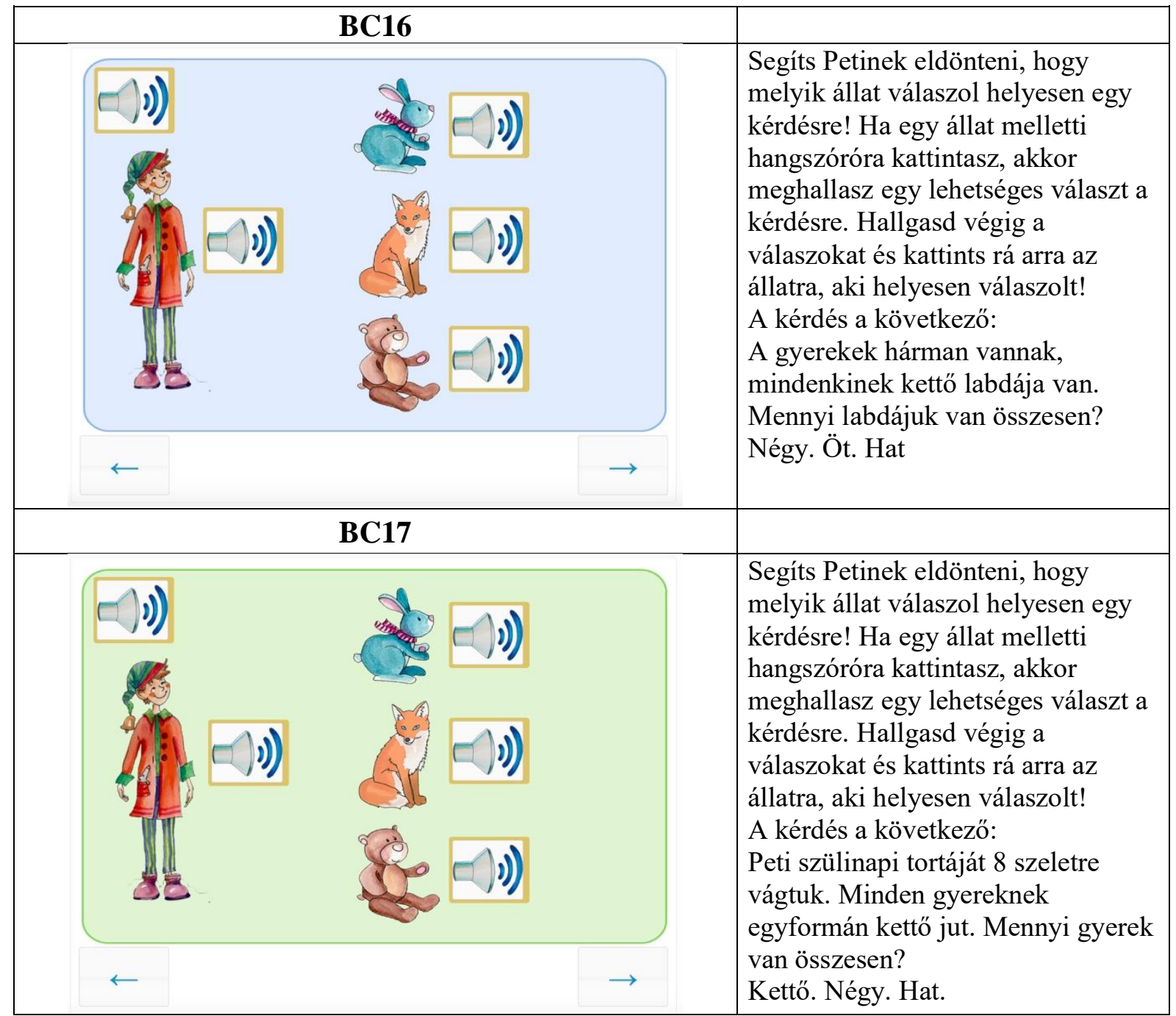




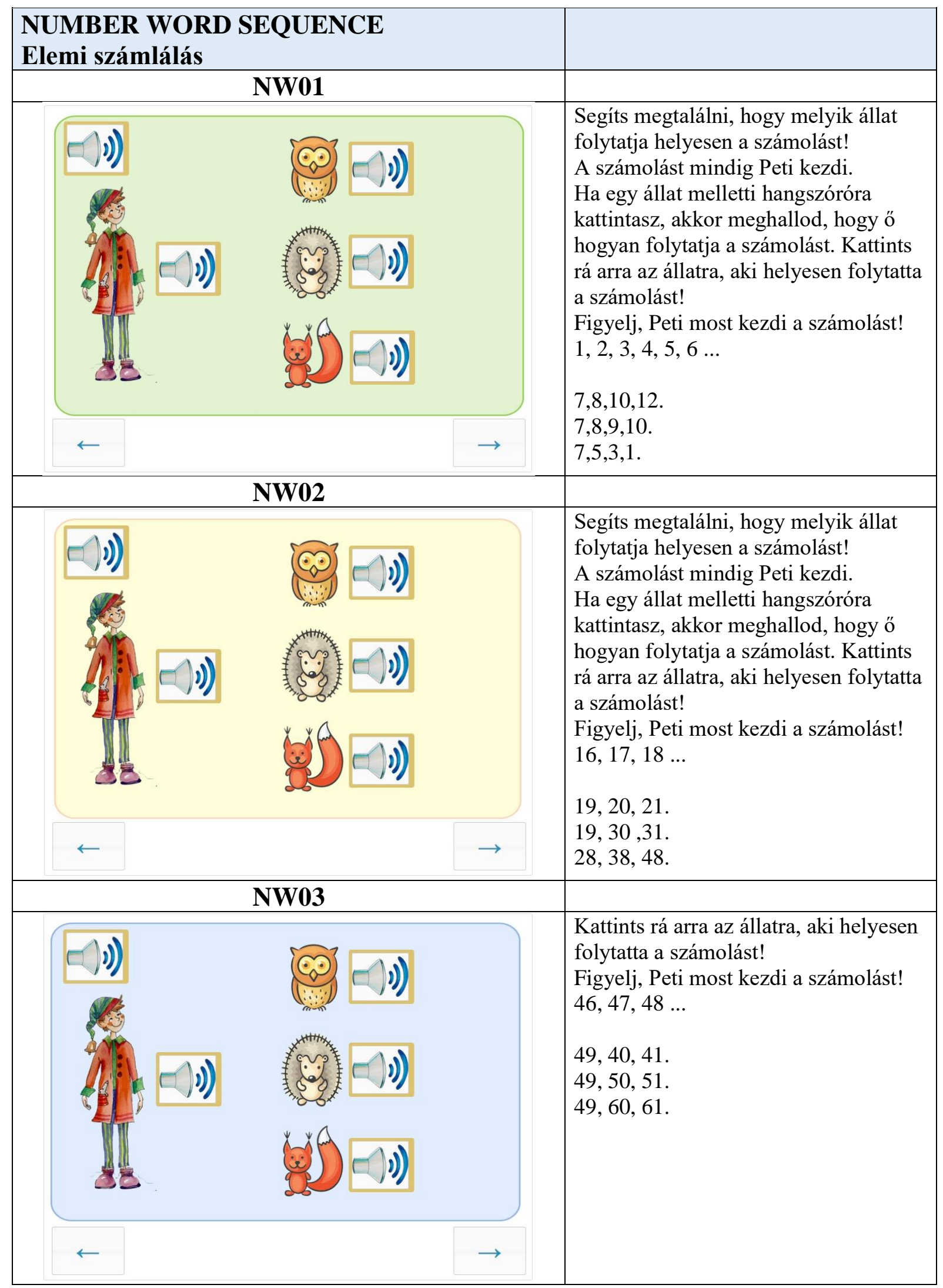




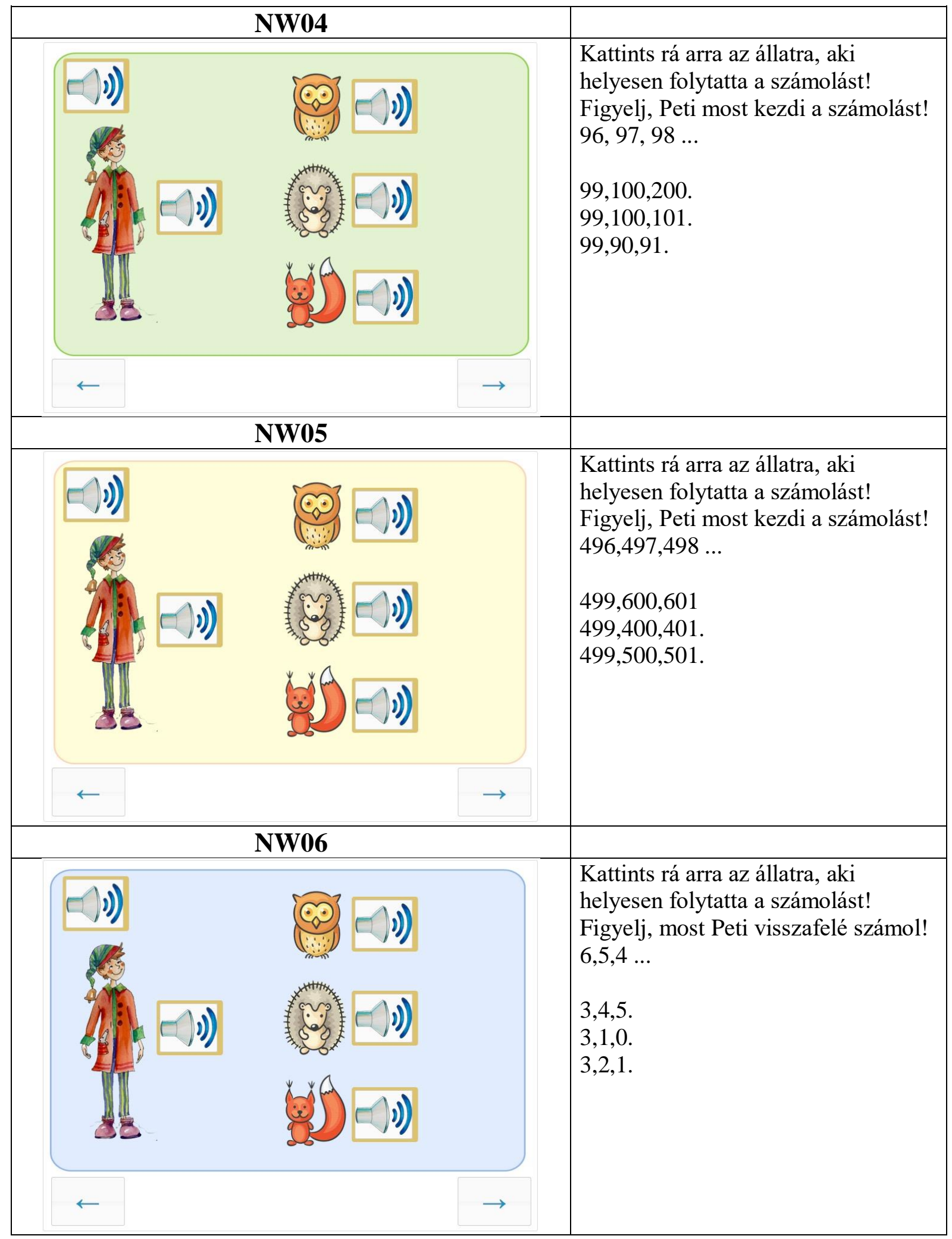




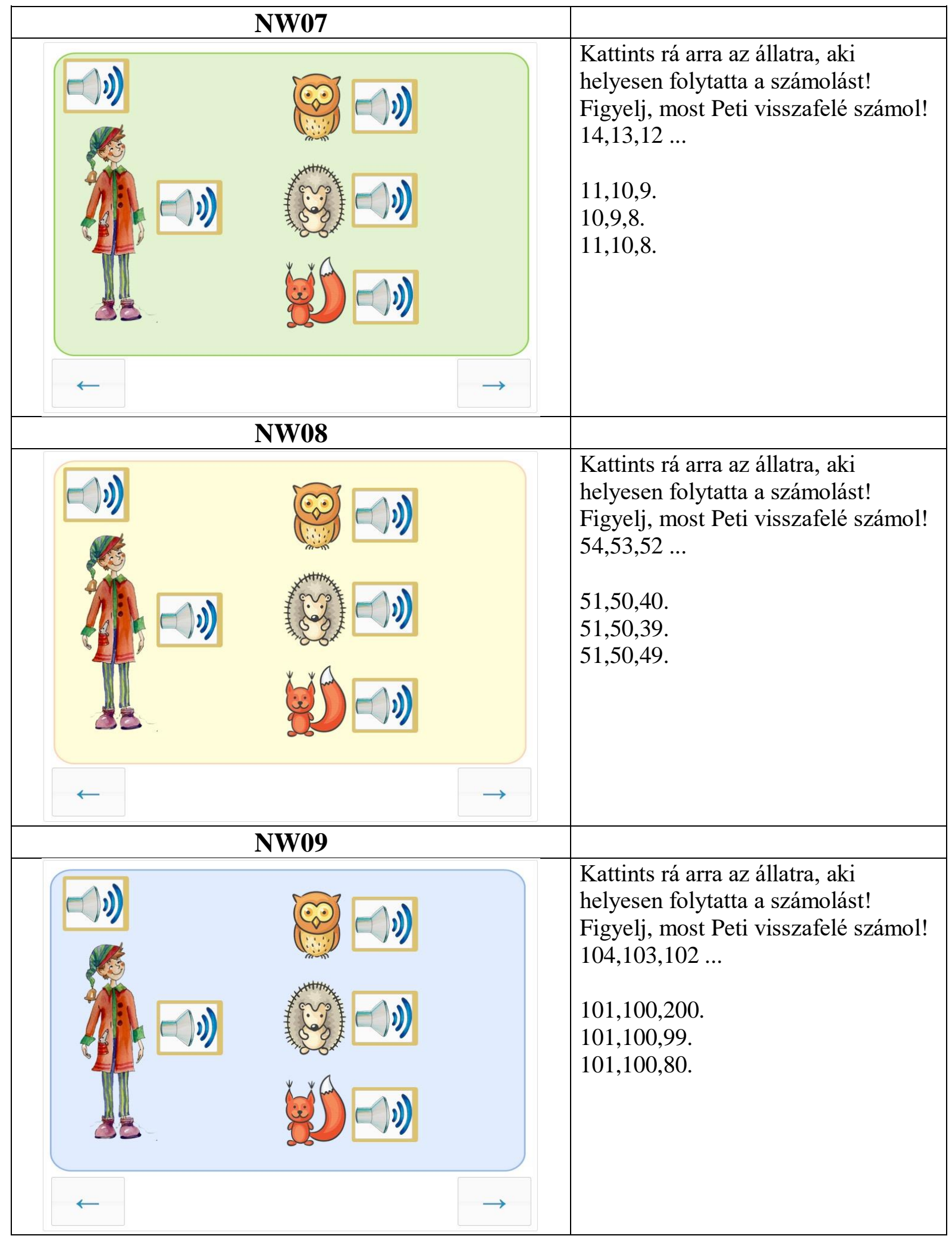




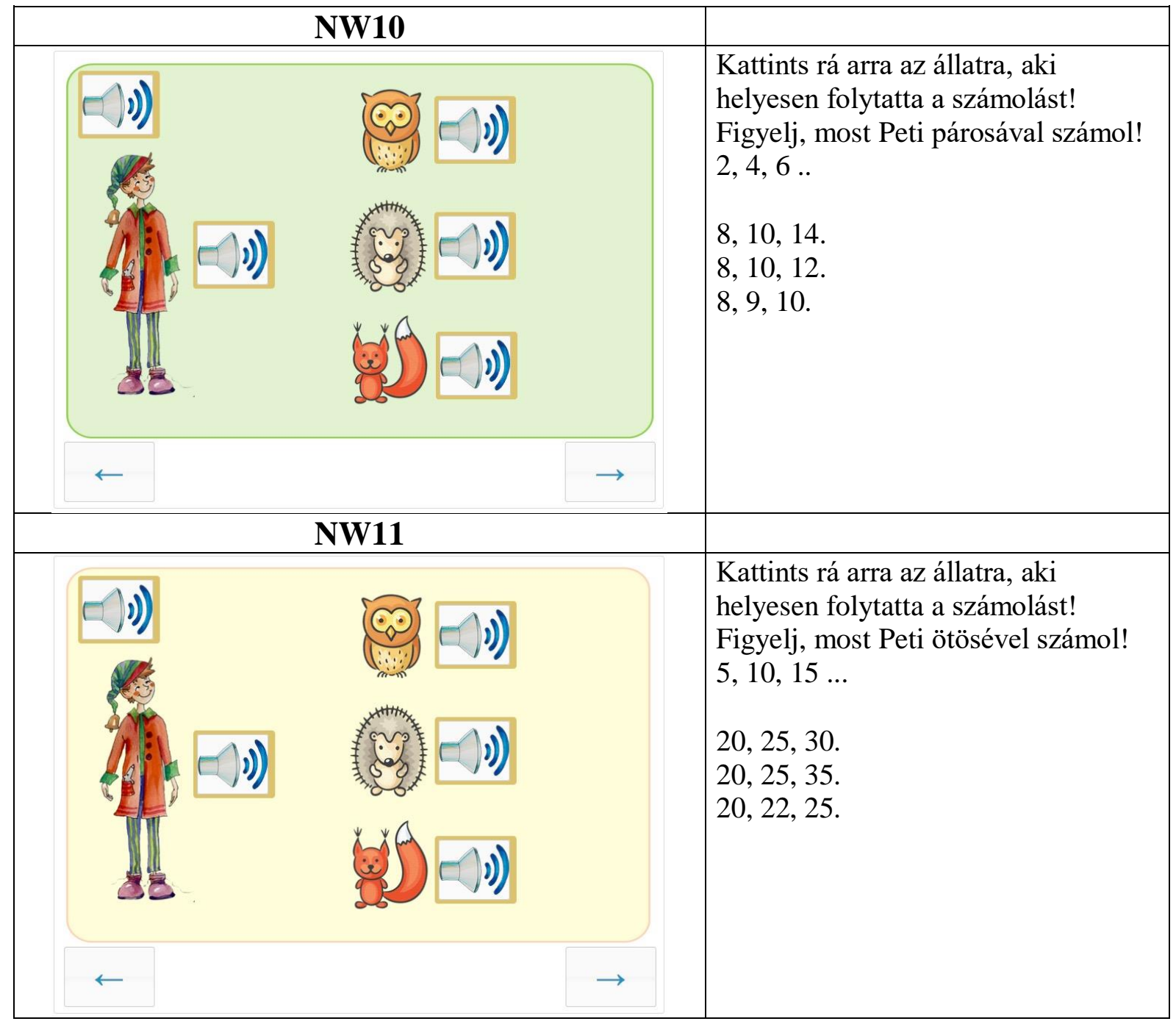

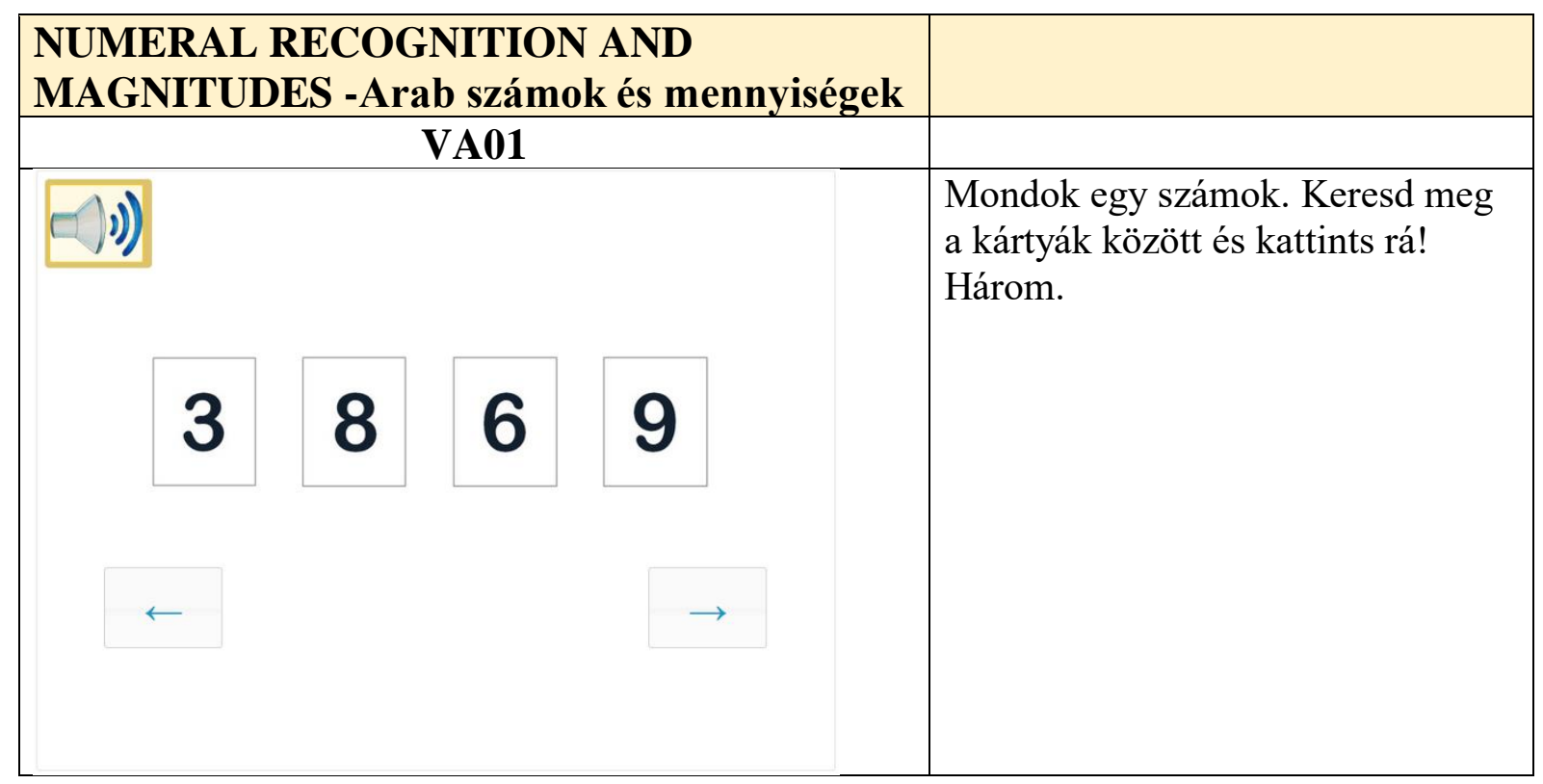




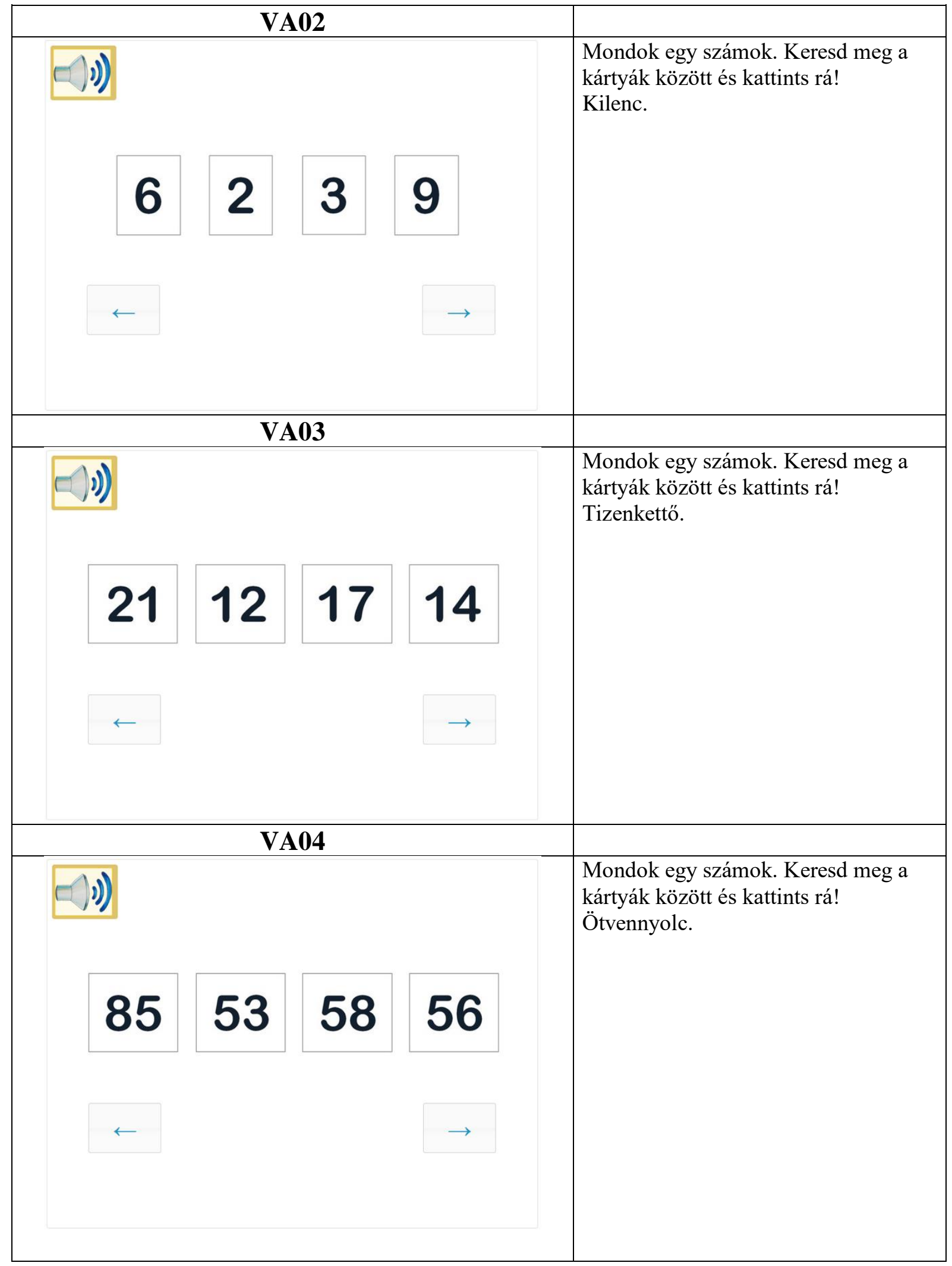




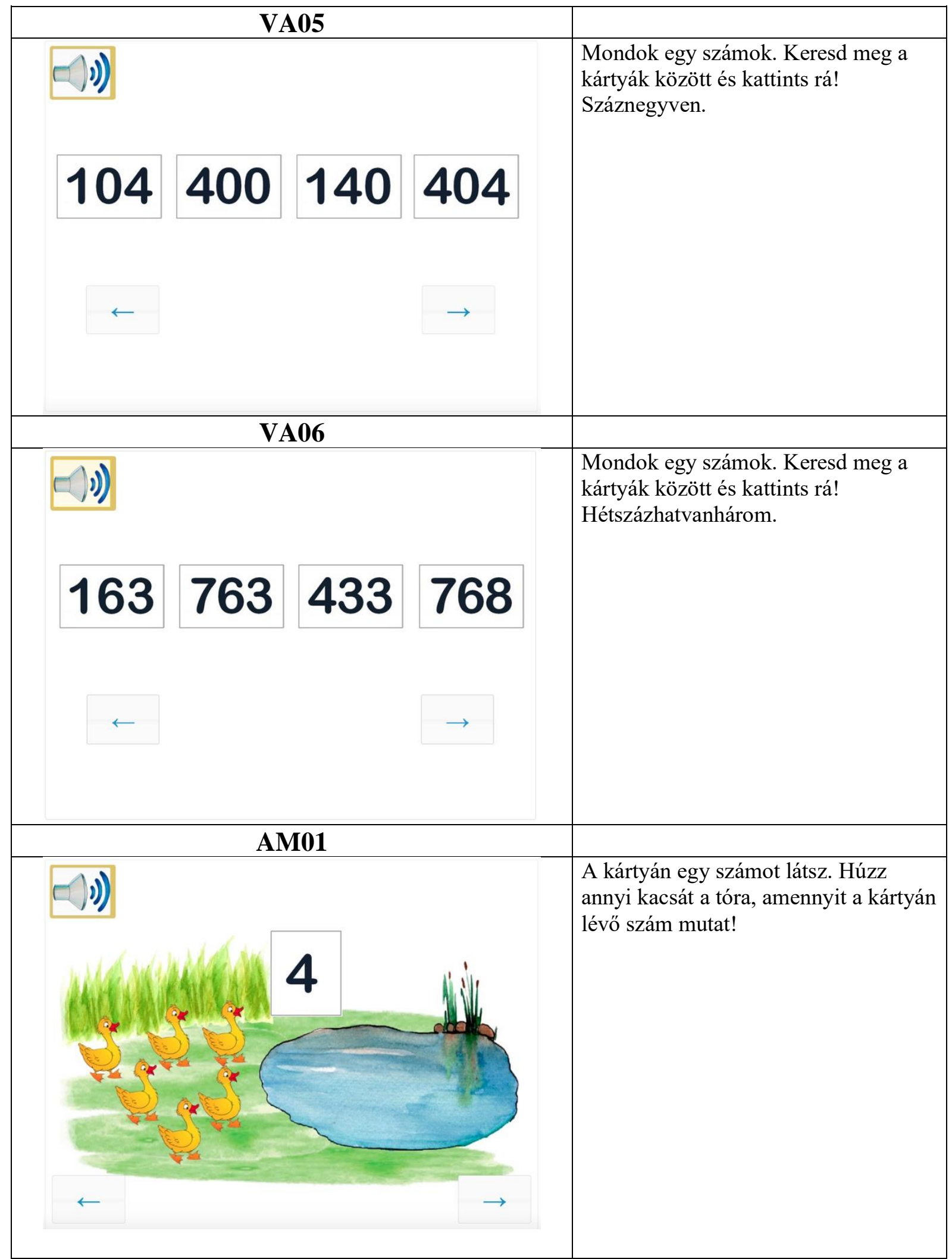




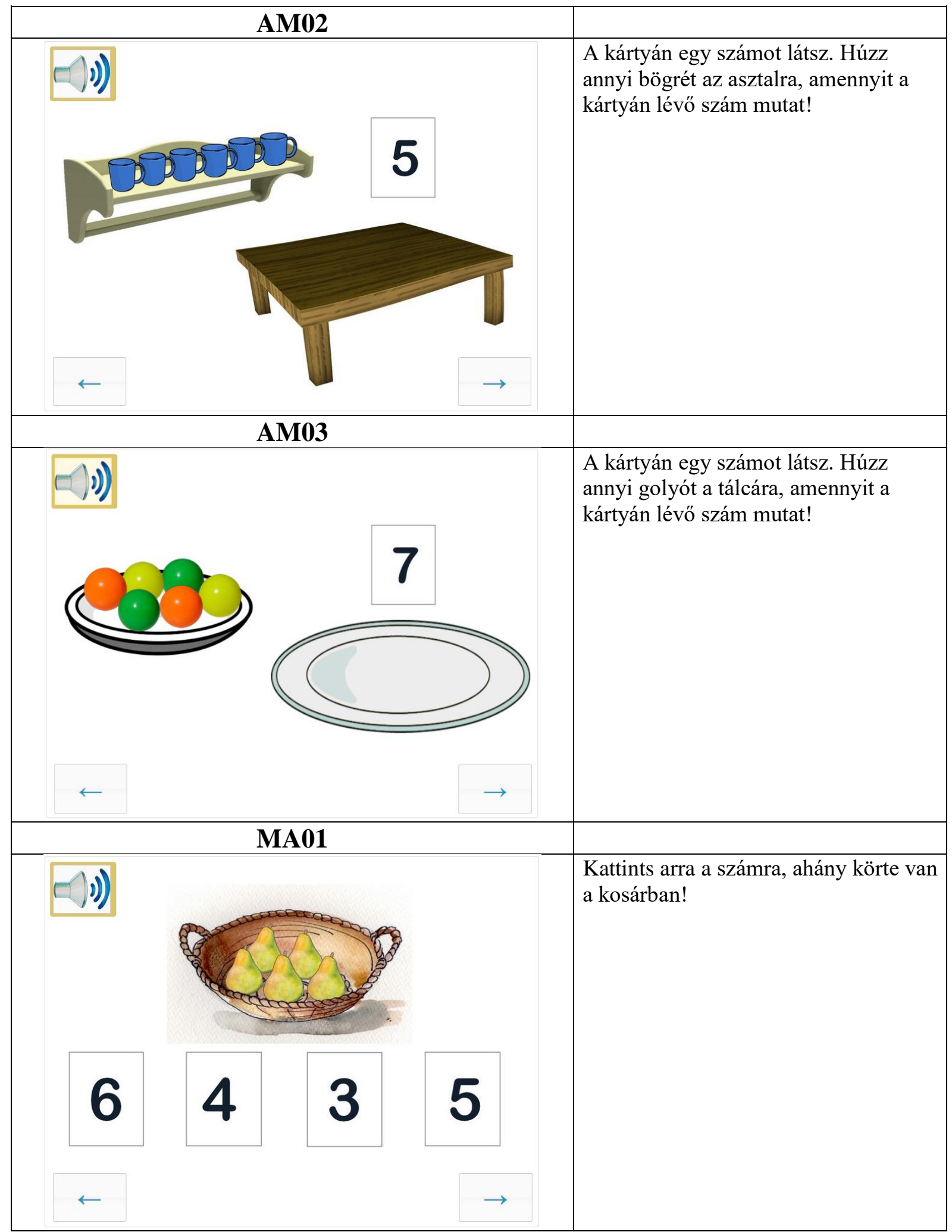




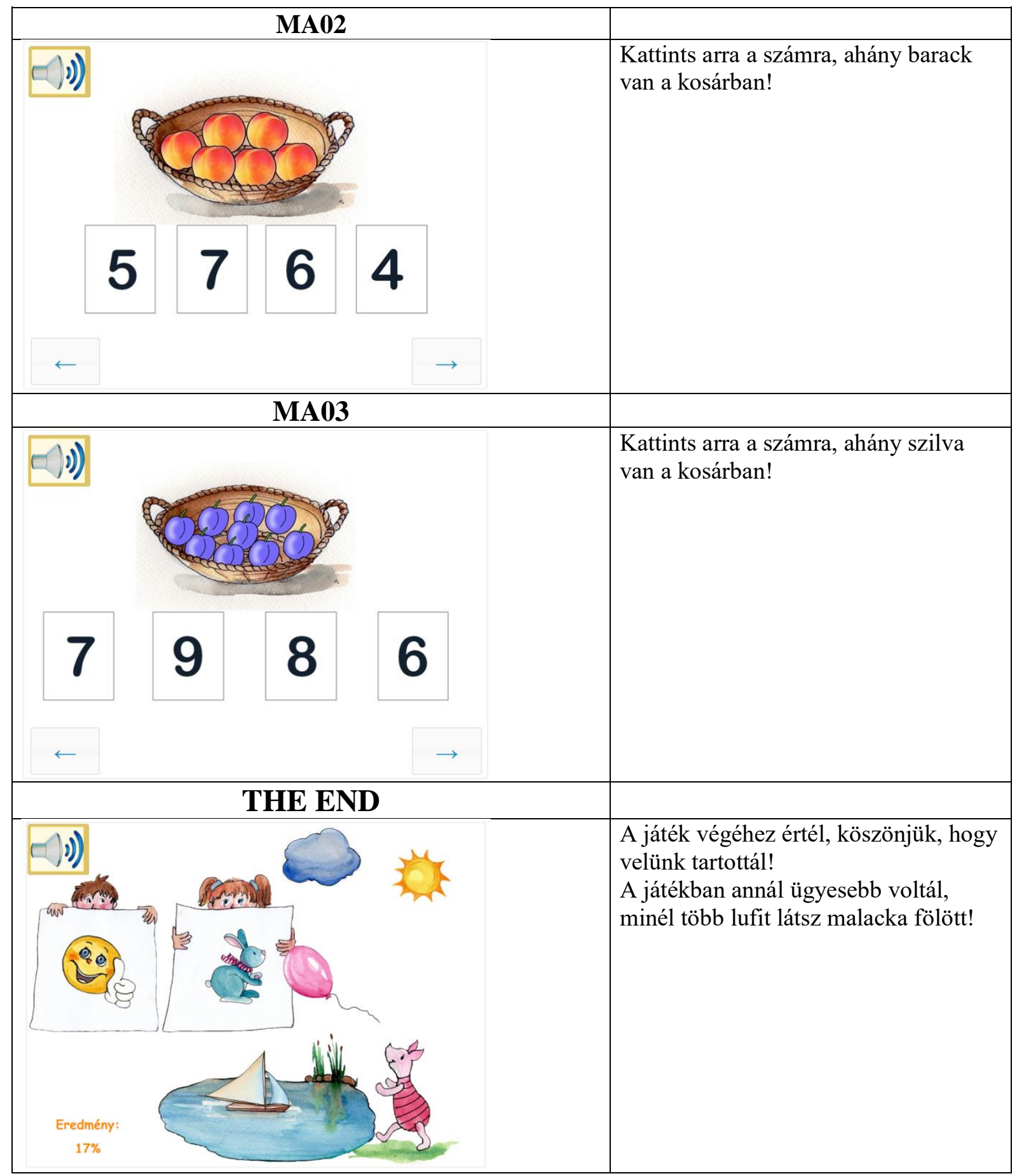


3. Melléklet. 1. évfolyam végi matematika teszt

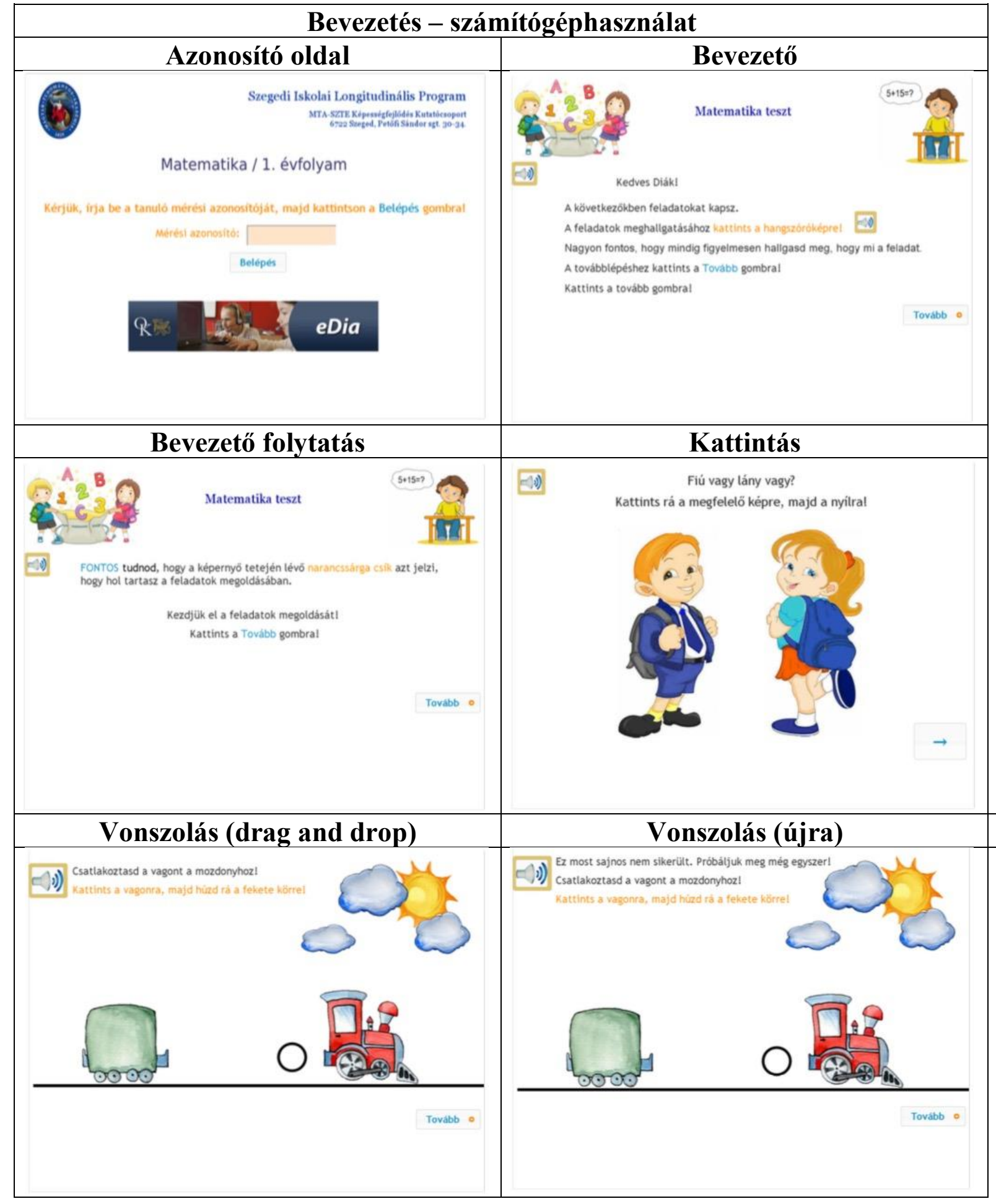




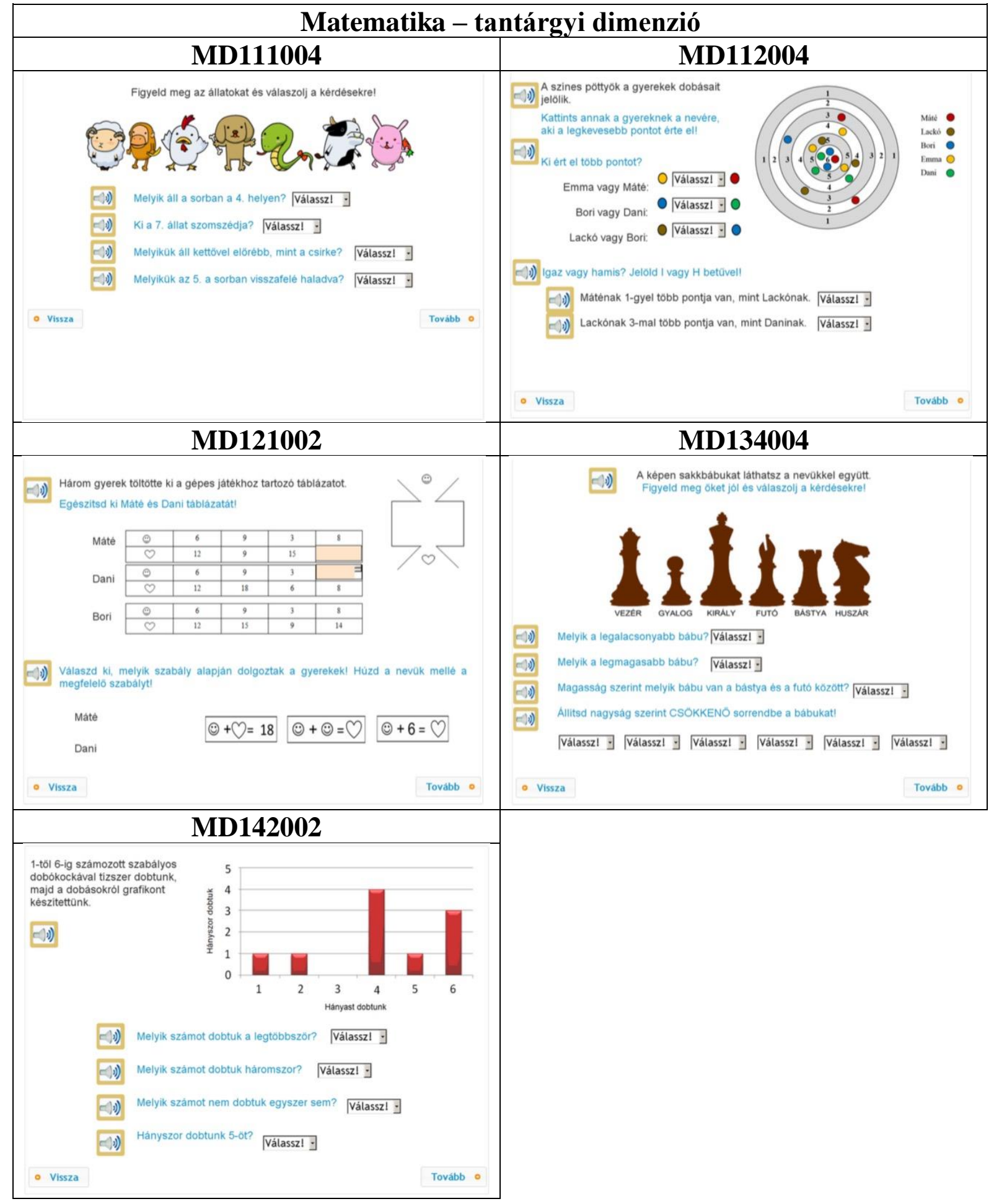




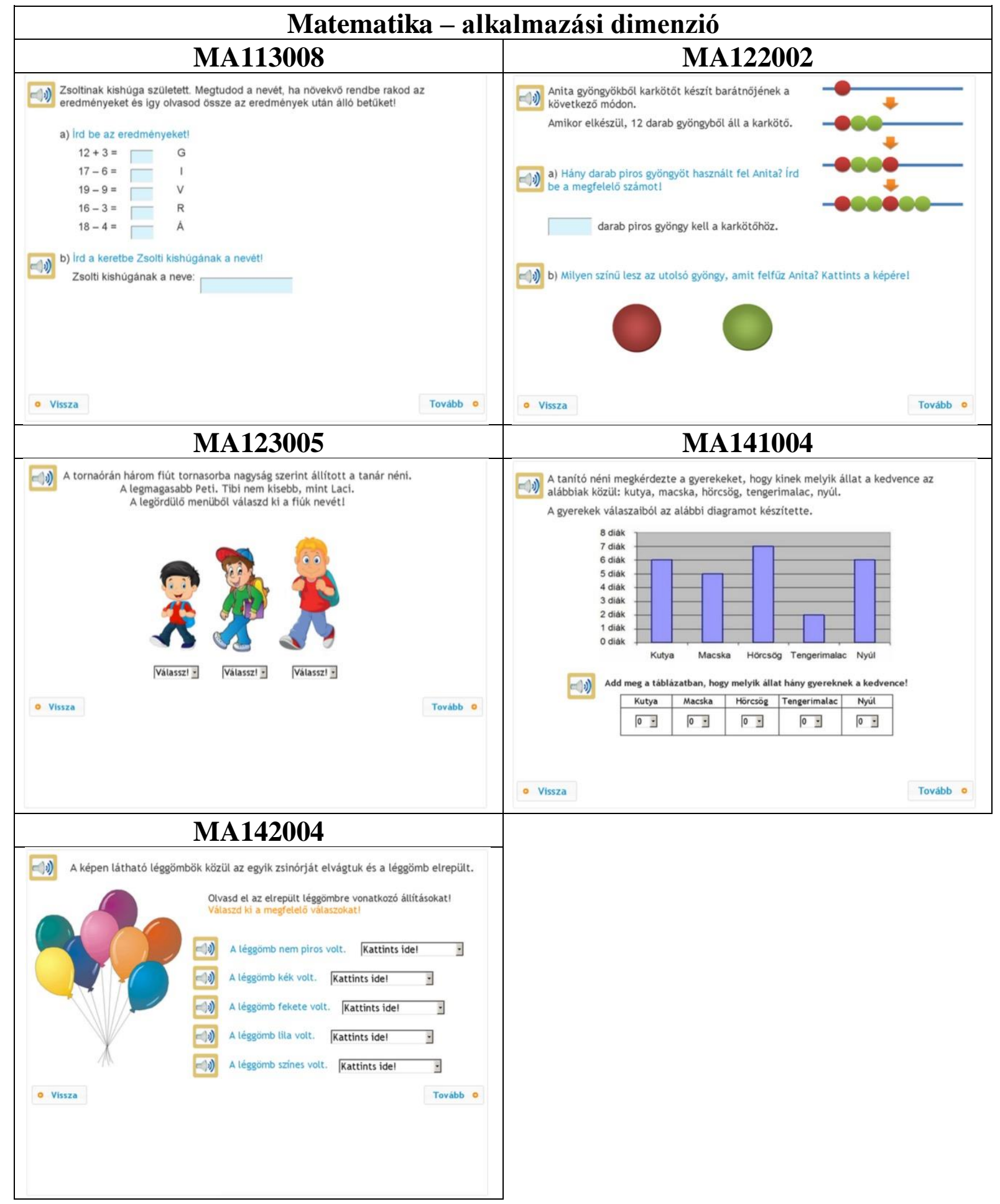




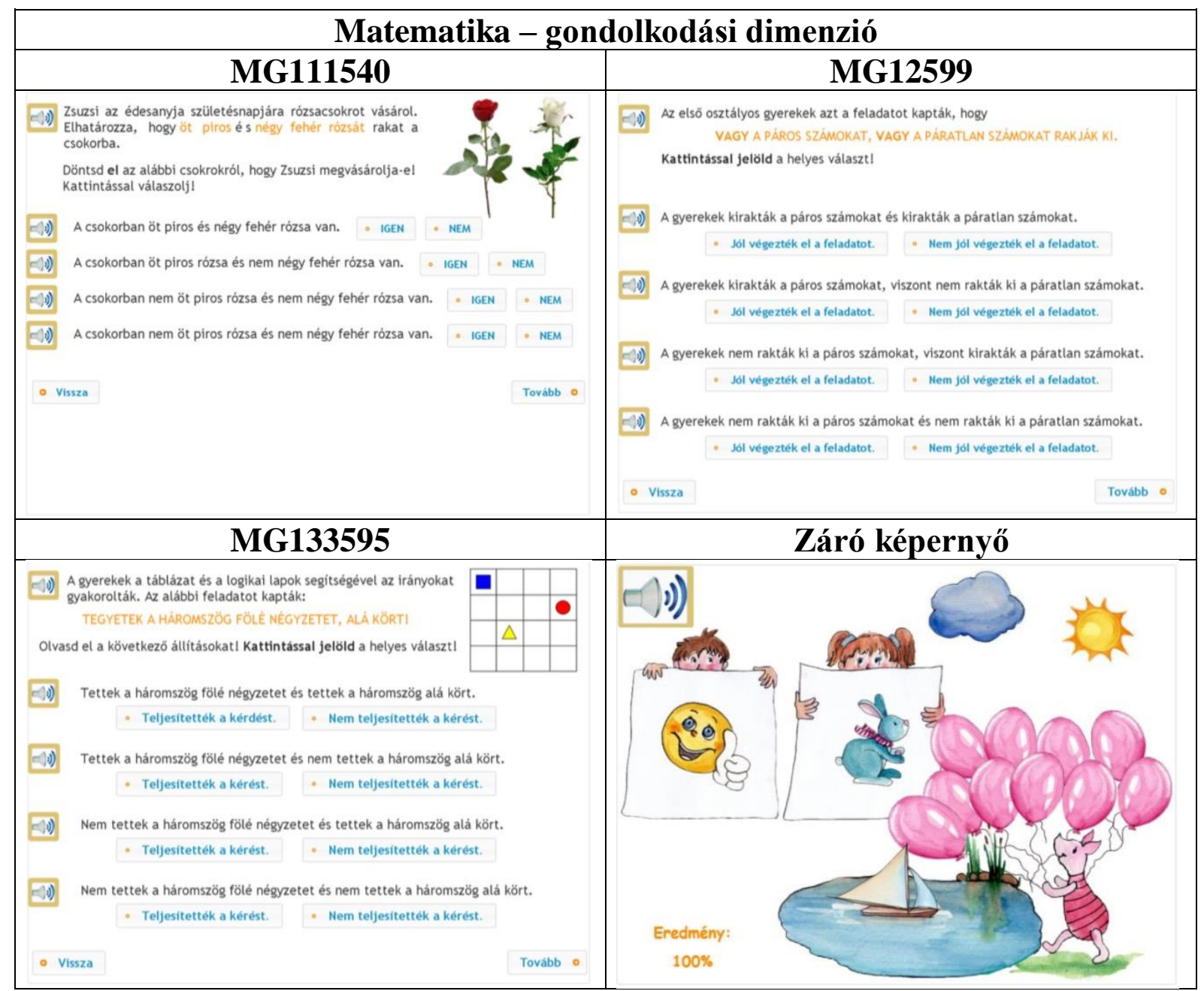




\section{Melléklet. Szülői beleegyező nyilatkozatok}

SZEGEDI TUDOMÁNYEGYETEM

Neveléstudományi Doktori Iskola

6722 Szeged, Petőfi Sgt. 30-34.

Tel.: +36-62-343-281

Home: http://www.edu.u-szeged.hu/phd/

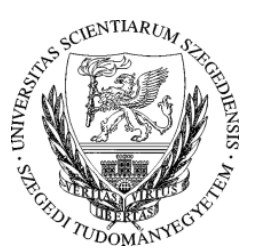

RAUSCH ATTILA

egyetemi tanársegéd, doktorjelölt

Tel.: +36-20-535-14-37

E-mail: rausch@edu.u-szeged.hu

Home: http://www.edu.u-szeged.hu/phd/people/rausch

\section{Beleegyező nyilatkozat}

Kijelentem, hogy az Szegedi Tudományegyetem Oktatáselméleti Kutatócsoport által végzendő óvodai mérés-értékelési folyamatot kiegészítő, számolási készségeket felmérő vizsgálatban engedélyezem gyermekem részvételét.

Tudomásul veszem, hogy a gyermekem azonosítására alkalmas személyi adatokat bizalmasan kezelik. Hozzájárulok ahhoz, hogy a vizsgálat során a felvett, gyermekem azonosítására nem alkalmas adatok más kutatók számára is hozzáférhetők legyenek.

Továbbá nyilatkozok arról, hogy engedélyezem-e a SZTE Oktatáselméleti Kutatócsoportjának munkatársai számára kép- és hangfelvétel készítését gyermekemről, mely magát a tesztelést és annak menetét szemlélteti. A kutatócsoport az elkészült felvételeket kizárólag a gyermekek számítógép alapú tesztelésen szerzett élményeit kívánja szemléltetni konferencia előadások alkalmával, azok sem webes, sem kiadvány formájában nem jelennek meg nyilvánosan.

Fenntartom a jogot arra, hogy a vizsgálat során annak folytatásától bármikor elállhassak.

Alulírott beleegyezem, hogy gyermekem részt vegyen

az óvodai méréseken.

Ezen felül hozzájárulok, hogy gyermekemről kép és hangfelvétel készüljön a mérés során. Igen / Nem (a megfelelő aláhúzandó)

Gyermek neve:

Születési dátuma:

Kecskemét, 2016. november 29.

aláírás 
SZEGEDI TUDOMÁNYEGYETEM

OKTATÁSELMÉLETI KUTATÓCSOPORT

TÁMOP 3.1.9-11/1-2012-0001

DIAGNOSZTIKUS MERESEK FELESZTESE

\section{SZÉCHENYI 2020}

\section{Beleegyező nyilatkozat}

Kijelentem, hogy a SZTE Oktatáselméleti Kutatócsoport által végzendô, az óvodai mérés-értékelési folyamatot kiegészitô online tesztekben engedélyezem gyermekem részvételét. A vizsgálat jellegéről annak megkezdése elött kielégitoó tájékoztatást kaptam.

Tudomásul veszem, hogy a gyermekem azonositására alkalmas személyi adatokat bizalmasan kezelik. Hozzájárulok ahhoz, hogy a vizsgálat során a felvett, gyermekem azonosittására nem alkalmas adatok más kutatók számára is hozzáférhetốk legyenek.

A méréshez való hozzájárulás jeleként kitoöltöm a dokumentum kōvetkezō oldalán lévő táblázatot, melyben rögzítem gyermekem csoportját, nevét és születési dátumát.

A táblázatban igen (I) vagy nem ( $\mathrm{N}$ ) jelzést teszek arra vonatkozóan, hogy engedélyezem-e a Szegedi Tudományegyetem Oktatáselméleti Kutatócsoportjának munkatársai számára kép és hangfelvétel készitését gyermekemrôl, mely magát a tesztelést és annak menetét szemlélteti.

Az Oktatáselméleti Kutatócsoport az elkészült felvételeket kiadványokhoz, webes megjelenésekhez kizárólag nonprofit módon has ználja fel. A felvételek alapján készült videókkal, kiadványokkal a kutatócsoport szemléltetni kivánja a gyermekek számítógép alapú tesztelésen szerzett élményeit.

Email címemre rövid idổn belül a kutatócsoport egy háttérkérdốivet küld, melybe gyermekem azonositójával fogok tudni belépni. A háttérkérdőivben anonim módon olyan háttéradatokat adok meg, melyek kapcsolatba hozhatók gyermekem teszten nyújtott teljesítményével.

Fenntartom a jogot arra, hogy a vizsgálat során annak folytatásától bármikor elállhassak.

Tudomásul veszem, hogy a vizsgálat eredményéröl külön laboratóriumi lelet, orvosi zárójelentés nem készül.

Kelt: Szeged, 2015. december 22

SZTE Oktatáselméleti Kutatócsoport

6722 Szeged, Petófi S. sgt. 30-34.

Tel., fax: (62) 544354

Web: www.u-szeged.hu/ok

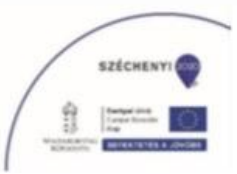

\begin{tabular}{|c|c|c|c|c|c|}
\hline Csoport & Név & Születési dátum & $\begin{array}{l}\text { Vágókép készítésébe } \\
\text { történô beleegyezés } \\
\qquad(\mathrm{I} / \mathrm{N})\end{array}$ & A szülö email címe & A szülỗ aláírása \\
\hline pl. Mackó & pl. Teszt Elek & pl. 2011.04.08. & pl. I & pl. elek@elek.hu & \\
\hline & & & & & \\
\hline & & & & & \\
\hline & & & & & \\
\hline & & & & & \\
\hline & & & & & \\
\hline & & & & & \\
\hline & & & & & \\
\hline & & & & & \\
\hline & & & & & \\
\hline & & & & & \\
\hline & & & & & \\
\hline & & & & & \\
\hline & & & & & \\
\hline & & & & & \\
\hline
\end{tabular}




\title{
5. Melléklet. Mérési útmutató - iskolai mérés
}

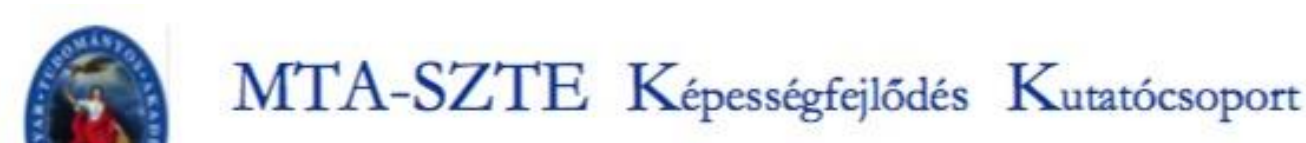

Research Group on the Development of Competencies

H-6722 Szeged, Petófi Sándor sgt. 30-34. Tel./ Fax: 36/62-544-354 www-edu-u-szeged.hu/kkcs e-mail longi@edu.u-szeged hu

\author{
MÉRÉSI ÚTMUTATÓ \\ az ONLINE ISKOLAKEZDÉS MÉRŌESZKÖZCSOMAG felvételéhez
}

Kedves Kapcsolattartó Kolléga!

Örömünkre szolgál, hogy az Ōn iskolája is bekapcsolódott az MTA-SZTE Képességfejlődés Kutatócsoport Szegedi Iskolai Longitudinális Programjába. A követõ mérési ciklus a sikeres iskolakezdéshez szükséges elökészségek fejlettségének felmérésével indul. A vizsgált képességekkel, az egyes tesztekkel kapcsolatos kérdéseire a területek szakmai felelösei válaszolnak. Az ô elérhetőségüket és a tesztek mintafeladatokkal illusztrált rövid bemutatását a csatolt „Online iskolakezdés méröeszközcsomag" fájlban találja.

A mérések számítógép segítségével, online, az eDia (www.edia.hu) rendszeren keresztül zajlanak. A méröeszközcsomag HAT tesztből áll, amelyeket a tanulók életkori sajátosságai miatt öt mérési időpontban vesszük fel. Ahhoz, hogy pontos képet kapjunk a tanulók képességeinek fejlettségérōl, feltétlenül szükség van a táblázatban található első négy teszt felvételére. A zenei képességek mérését a csatolt leírásban olvasható okok miatt javasoljuk.

A tesztek javasolt sorrendjét és elérhetőségét az alábbi táblázat mutatja.

\begin{tabular}{c|l|l}
\hline \hline Mérési sorrend & \multicolumn{1}{|c|}{ Mért terület } & A tesztek elérhetôsége \\
\hline 1. alkalom & $\begin{array}{l}\text { Számitógépesegér-használat } \\
\text { Induktív gondolkodás }\end{array}$ & edia.hu/longind \\
\hline 2. alkalom & Olvasás elökészségei & edia.hu/longolv \\
\hline 3. alkalom & Matematikatanulás elökészségei & edia.hu/longmat \\
\hline 4. alkalom & Feladattartás & edia.hu/longftart \\
\hline 5. alkalom & Zenei képességek & edia.hu/longzene \\
\hline \hline
\end{tabular}

A tesztek elején két-két játékos próbafeladat van, amelyek a ráhangolódást, az egér kezelését, a válaszadás technikájának a felelevenítését szolgálják. A tesztek úgynevezett hangos feladatokból állnak. Minden feladatban egy narrátor elmondja, mit kell tenniük a tanulóknak (A képernyőn a feladatok szöveges formában nem jelennek meg.). Mivel az utasítások elöre rögzítettek, minden gyermek a saját tempójában haladhat a teszt kitöltésével. - Az instrukciókat közlő narráció automatikusan indul minden feladat esetében. Vannak feladok, amelyekben a tanulók többször meghallgathatják az utasításokat, vannak, amelyekben nem. Az erre vonatkozó információkat a tesztekhez tartozó adatfelvételi útmutatások tartalmazzák.

A teszteket szakaszokra bontottunk. Egy-egy szakasz végén a tanulók felállhatnak, ha kérik, kimehetnek a mosdóba. Az ezeket a pontokat jelző képernyōképet az egyes tesztekhez tartozó adatfelvételi útmutatások tartalmazzák. 


\section{A kitöltéshez tesztenként 20-30 percre van szükség.}

Kérjük, hogy a hat teszt kitöltéséhez öt külön időpontot biztosítson! Ideális, ha egy tanítási napon a tanulók csak egy feladatsort oldanak meg. Ugyanazon a tanitási napon két teszt is kitölthetō, de arra két külön tanítási órán kerüljön sor. A mérési alkalmak ne essenek egymástól távol. Ideális, ha egy osztályban valamennyi adatfelvétel két hét alatt lezajlik.

Kérjük, a tesztek kitöltése alatt tartózkodjon a teremben egy, az osztályt tanító, a tanulók által ismert pedagógus.

A tesztek kitöltésének idốszaka: 2015. október 1. - 2015. november 10.

Mivel a tanulók különböző tapasztalatokkal rendelkeznek a számítógép használatában, FONTOS, hogy a vizsgálatsorozat a „Számitógépesegér-használat - Induktiv gondolkodás” tesztpár felvételével induljon. Kérjük, ennek kitöltését legkésőbb 2015. október 13-ig végezzék el! A szerződés kifizetését csak ezután tudjuk elinditani.

A mérések lebonyolitásának lépései:

- a terem elōkészitése a mérésre - a számitógépek elōkészitése (böngészõ program frissítése), bekapcsolása, a fülhallgatók csatlakozatása, a feladatsor betöltése.

FONTOS! A feladatok kellő sebességü betöltôdésének egyik feltétele, hogy a gépeken a böngészõ programok (Mozilla Firefox vagy Google Chrome) legfrissebb változatai legyenek.

- a tanulók mérési azonosítóinak begépelése, a tanulók leültetése a saját mérési azonosítójával beléptetett géphez,

- a tanulók segítése az esetleges technikai problémák megoldásban a tesztkitöltés során,

- az eredmények rögzitése. - Mikor a tanulók teszt végre értek, eredményük százalékos formában megjelenik a képernyön, melyeket az eDia rendszer egy adatbázisban rögzít. Azok az elemzésekkel együtt az adatfelvételi időszak lezárulta után lesznek elérhetők az eDiában. Amennyiben szeretnék azonnal áttekinteni a tanulók eredményeit, javasoljuk, gyüjtsék össze azokat egy táblázatban.

FONTOS! A diákok azonosítóival csak egyszer lehet belépni a tesztekbe. Minden tanuló azonosítója csak EGYETLEN KITÖLTÉST TESZ LEHETŐVÉ. Kérjük, ne használja egyetlen tanuló azonosítóját sem a tesztek megtekintésére.

Ha egy tanuló hiányzik az adatfelvétel időpontjában, kérjük, biztositson számára lehetőséget, hogy egy későbbi időpontban megoldja a feladatsort.

A mérések során adódó technikai kérdések, problémák megoldásában Kállai Istvánt segít.

Telefonszám: a 06-62-343-068;

Email cim: longi@edu.u-szeged.hu

\section{Köszönjük, hogy munkájával támogatja a program müködését!}


6. Melléklet. DIFER Adatfelvevő lap - Óvodai mérés

Név:

DIFER MÉRÉS

Azonosító:

I.

Relációszókincs

\begin{tabular}{|l|l|l|l|l|l|l|l|l|l|l|l|l|l|l|l|l|l|l|l|l|l|l|l|}
\hline $\mathbf{A}$ & $\mathbf{B}$ & $\mathbf{C}$ & $\mathbf{D}$ & $\mathbf{E}$ & $\mathbf{F}$ & $\mathbf{G}$ & $\mathbf{H}$ & $\mathbf{I}$ & $\mathbf{J}$ & $\mathbf{K}$ & $\mathbf{L}$ & $\mathbf{M}$ & $\mathbf{N}$ & $\mathbf{O}$ & $\mathbf{P}$ & $\mathbf{R}$ & $\mathbf{S}$ & $\mathbf{T}$ & $\mathbf{U}$ & $\mathbf{V}$ & $\mathbf{X}$ & $\mathbf{Y}$ & $\mathbf{Z}$ \\
\hline & & & & & & & & & & & & & & & & & & & & & & & \\
\hline
\end{tabular}

II.

\begin{tabular}{|c|c|c|c|c|c|c|c|c|c|c|c|c|c|c|c|c|c|c|c|c|c|c|c|}
\hline \multicolumn{24}{|c|}{ Elemi számolási készség } \\
\hline \multicolumn{4}{|c|}{ Számlálás } & \multicolumn{6}{|c|}{ Számkörök átlépése } & \multicolumn{14}{|c|}{ Számlálás visszafelé } \\
\hline \multicolumn{4}{|c|}{$0-21$} & $\begin{array}{l}\text { A } \\
30\end{array}$ & B & & $C$ & $\begin{array}{c}\text { D } \\
100\end{array}$ & $\begin{array}{r}\mathbf{E} \\
50\end{array}$ & & $\begin{array}{l}\text { A } \\
\leftarrow 2\end{array}$ & & & $\begin{array}{c}\text { C } \\
3 \leftarrow 6\end{array}$ & & D & $\begin{array}{r}\mathbf{E} \\
18 \leftarrow\end{array}$ & 4 & $\begin{array}{c}\mathbf{F} \\
18 \leftarrow 51\end{array}$ & 984 & 101 & $\begin{array}{r}\mathbf{r} \\
498\end{array}$ & 501 \\
\hline \multicolumn{11}{|c|}{ Múveletek pálcikákkal } & \multicolumn{9}{|c|}{ Számképfelismerés } & \multicolumn{4}{|c|}{ Számolvasás } \\
\hline $\begin{array}{l}\text { A } \\
1\end{array}$ & $\begin{array}{l}\text { B } \\
3\end{array}$ & $\begin{array}{l}C \\
5\end{array}$ & $\begin{array}{l}\text { D } \\
6\end{array}$ & $\begin{array}{c}\mathbf{E} \\
10\end{array}$ & $\mathbf{F}$ & $\begin{array}{c}\mathbf{G} \\
15\end{array}$ & \begin{tabular}{|l|}
$\mathbf{H}$ \\
20
\end{tabular} & I & 16 & $\begin{aligned} & \mathbf{K} \\
= & 16\end{aligned}$ & $\begin{array}{c}\mathbf{A} \\
1\end{array}$ & B & C & \begin{tabular}{|l|} 
D \\
5
\end{tabular} & $\mathbf{E}$ & $\begin{array}{c}\mathbf{F} \\
10\end{array}$ & $\begin{array}{c}\mathbf{G} \\
\mathrm{c}+\mathrm{d}\end{array}$ & $\begin{array}{l}\mathbf{H} \\
a+b\end{array}$ & $\begin{array}{c}\mathbf{I} \\
\text { acd }\end{array}$ & $\begin{array}{l}\mathbf{A} \\
1 \ldots\end{array}$ & $\begin{array}{c}\mathbf{B} \\
10 \ldots\end{array}$ & $\begin{array}{c}\mathbf{C} \\
22 \ldots\end{array}$ & $\begin{array}{c}\mathbf{D} \\
118\end{array}$ \\
\hline & & & & & & & & & & & & & & & & & & & & & & & \\
\hline
\end{tabular}

Név:

DIFER MÉRÉS

Azonosító:

I. Relációszókincs

\begin{tabular}{|l|l|l|l|l|l|l|l|l|l|l|l|l|l|l|l|l|l|l|l|l|l|l|l|}
\hline $\mathbf{A}$ & $\mathbf{B}$ & $\mathbf{C}$ & $\mathbf{D}$ & $\mathbf{E}$ & $\mathbf{F}$ & $\mathbf{G}$ & $\mathbf{H}$ & $\mathbf{I}$ & $\mathbf{J}$ & $\mathbf{K}$ & $\mathbf{L}$ & $\mathbf{M}$ & $\mathbf{N}$ & $\mathbf{O}$ & $\mathbf{P}$ & $\mathbf{R}$ & $\mathbf{S}$ & $\mathbf{T}$ & $\mathbf{U}$ & $\mathbf{V}$ & $\mathbf{X}$ & $\mathbf{Y}$ & $\mathbf{Z}$ \\
\hline & & & & & & & & & & & & & & & & & & & & & & & \\
\hline
\end{tabular}

II.

\begin{tabular}{|c|c|c|c|c|c|c|c|c|c|c|c|c|c|c|c|c|c|c|c|c|c|c|c|}
\hline \multicolumn{24}{|c|}{ Elemi számolási készség } \\
\hline \multicolumn{4}{|c|}{ Számlálás } & \multicolumn{6}{|c|}{ Számkörök átlépése } & \multicolumn{14}{|c|}{ Számlálás visszafelé } \\
\hline \multicolumn{4}{|c|}{$0-21$} & $\begin{array}{l}\text { A } \\
30\end{array}$ & $\begin{array}{l}\text { B } \\
40\end{array}$ & & C & $\begin{array}{c}\text { D } \\
100\end{array}$ & $\begin{array}{c}\mathbf{E} \\
500\end{array}$ & & $\begin{array}{l}\text { A } \\
\leftarrow 2\end{array}$ & $\begin{array}{r}\text { B } \\
1 \leftarrow\end{array}$ & & $\begin{array}{c}\text { C } \\
3 \leftarrow 6\end{array}$ & & $\begin{array}{l}D \\
-11\end{array}$ & $\begin{array}{c}\mathbf{E} \\
18 \leftarrow 21\end{array}$ & 2148 & $\begin{array}{c}\mathbf{F} \\
8 \leftarrow 51\end{array}$ & $98 \leftarrow$ & 101 & $\begin{array}{r}\mathbf{r} \\
498 \leftarrow\end{array}$ & 501 \\
\hline \multicolumn{11}{|c|}{ Múveletek pálcikákkal } & \multicolumn{9}{|c|}{ Számképfelismerés } & \multicolumn{4}{|c|}{ Számolvasás } \\
\hline A & B & C & D & $E$ & $\mathbf{F}$ & G & H & I & J & $\mathbf{K}$ & A & B & C & D & $\mathbf{E}$ & $\mathbf{F}$ & $\mathbf{G}$ & $\mathbf{H}$ & $\mathbf{I}$ & A & B & C & D \\
\hline 1 & 3 & 5 & 6 & 10 & 12 & 15 & 20 & 4 & 16 & $=16$ & 1 & 2 & 3 & 5 & 7 & 10 & $c+d$ & $a+b$ & acd & $1 \ldots$ & $10 \ldots$ & $22 \ldots$ & 118 \\
\hline
\end{tabular}


7. Melléklet. Reliabilitás-vizsgálatok eredményei - elkülönítésmutatók

Első tesztváltozat - óvoda

\begin{tabular}{|c|c|c|c|c|}
\hline Item & Skála átlaga & Skála variancia & $\begin{array}{c}\text { Elkülönítés- } \\
\text { mutató részteszt }\end{array}$ & $\begin{array}{l}\text { Elkülönítés- } \\
\text { mutató teljes }\end{array}$ \\
\hline VM01D & 29,3 & 139,1 & 0,627 & 0,477 \\
\hline VM02D & 29,2 & 139,0 & 0,752 & 0,542 \\
\hline VM03D & 29,3 & 138,2 & 0,738 & 0,562 \\
\hline VM04T & 29,2 & 138,3 & 0,764 & 0,569 \\
\hline VM05T & 29,4 & 138,3 & 0,580 & 0,519 \\
\hline VM06T & 29,4 & 138,1 & 0,565 & 0,542 \\
\hline ED01_FNS & 29,2 & 139,8 & 0,332 & 0,433 \\
\hline ED02_FNS & 29,4 & 140,5 & 0,322 & 0,331 \\
\hline ED03_FNS & 29,4 & 140,2 & 0,387 & 0,362 \\
\hline ED04_FNS & 29,4 & 141,1 & 0,378 & 0,281 \\
\hline ED05_FNS & 29,5 & 140,5 & 0,438 & 0,340 \\
\hline ED06_FNS & 29,5 & 139,8 & 0,421 & 0,401 \\
\hline ED07_BNS & 29,4 & 138,6 & 0,449 & 0,494 \\
\hline ED09_BNS & 29,5 & 143,1 & 0,139 & 0,113 \\
\hline ED10_BNS & 29,5 & 140,4 & 0,388 & 0,348 \\
\hline RM01_T1 & 29,1 & 141,3 & 0,325 & 0,368 \\
\hline RM02_T2 & 29,1 & 140,2 & 0,440 & 0,469 \\
\hline RM03_T3 & 29,2 & 140,7 & 0,330 & 0,359 \\
\hline RM04_K1 & 29,2 & 140,2 & 0,373 & 0,394 \\
\hline RM05_K2 & 29,3 & 139,0 & 0,483 & 0,477 \\
\hline RM06_K3 & 29,3 & 139,6 & 0,478 & 0,432 \\
\hline RM07_U1 & 29,3 & 139,1 & 0,472 & 0,467 \\
\hline RM08_U2 & 29,6 & 139,3 & 0,432 & 0,454 \\
\hline RM09_U3 & 29,2 & 138,3 & 0,530 & 0,550 \\
\hline RM10_S1 & 29,4 & 138,2 & 0,520 & 0,525 \\
\hline RM11_S2 & 29,7 & 141,0 & 0,438 & 0,393 \\
\hline RM12_S3 & 29,5 & 138,8 & 0,508 & 0,488 \\
\hline RM13_SN1 & 29,8 & 141,9 & 0,370 & 0,327 \\
\hline RM14_SN2 & 29,8 & 143,0 & 0,289 & 0,256 \\
\hline RM15_SN3 & 29,8 & 141,6 & 0,441 & 0,357 \\
\hline OM01_A1 & 29,3 & 137,0 & 0,680 & 0,666 \\
\hline OM02_A2 & 29,4 & 137,5 & 0,585 & 0,593 \\
\hline OM03_A3 & 29,4 & 137,1 & 0,586 & 0,625 \\
\hline OM04_K1 & 29,2 & 138,2 & 0,666 & 0,605 \\
\hline OM05_K2 & 29,2 & 137,7 & 0,688 & 0,638 \\
\hline OM06_B1 & 29,1 & 141,8 & 0,326 & 0,308 \\
\hline OM07_B2 & 29,1 & 140,6 & 0,413 & 0,409 \\
\hline OM08_B3 & 29,3 & 138,9 & 0,485 & 0,471 \\
\hline
\end{tabular}




\begin{tabular}{lcccc}
\hline Item & Skála átlaga & Skála variancia & $\begin{array}{c}\text { Elkülönítés- } \\
\text { mutató részteszt }\end{array}$ & $\begin{array}{c}\text { Elkülönítés- } \\
\text { mutató teljes }\end{array}$ \\
\hline VA01 & 29,12 & 138,2 & 0,573 & 0,658 \\
VA02 & 29,21 & 138,3 & 0,566 & 0,574 \\
VA03 & 29,33 & 137,1 & 0,683 & 0,634 \\
VA04 & 29,44 & 138,4 & 0,598 & 0,516 \\
VA05 & 29,66 & 141,7 & 0,398 & 0,273 \\
VA06 & 29,44 & 138,0 & 0,657 & 0,548 \\
\hline AM01_1 & 29,15 & 138,7 & 0,506 & 0,573 \\
AM02_2 & 29,11 & 138,7 & 0,735 & 0,614 \\
AM03_5 & 29,18 & 138,1 & 0,72 & 0,612 \\
AM04_7 & 29,29 & 137,7 & 0,641 & 0,594 \\
MA01_4 & 29,11 & 139,0 & 0,707 & 0,581 \\
MA02_5 & 29,17 & 138,3 & 0,639 & 0,602 \\
MA03_9 & 29,38 & 138,0 & 0,583 & 0,546 \\
MA04_6 & 29,24 & 138,6 & 0,643 & 0,531 \\
\hline
\end{tabular}


Második tesztváltozat - óvoda

\begin{tabular}{|c|c|c|c|c|}
\hline Item & Skála átlaga & Skála variancia & $\begin{array}{l}\text { Elkülönítés- } \\
\text { mutató részteszt }\end{array}$ & $\begin{array}{l}\text { Elkülönítés- } \\
\text { mutató teljes }\end{array}$ \\
\hline BAC01 & 20,64 & 29,99 & 0,465 & 0,389 \\
\hline $\mathrm{BAC} 02$ & 20,60 & 30,21 & 0,463 & 0,374 \\
\hline $\mathrm{BAC} 03$ & 20,64 & 29,53 & 0,596 & 0,490 \\
\hline BAC04 & 20,67 & 29,26 & 0,529 & 0,532 \\
\hline BAC05 & 20,72 & 29,30 & 0,535 & 0,483 \\
\hline BAC06 & 20,53 & 31,38 & 0,194 & 0,123 \\
\hline BAC07 & 20,53 & 30,96 & 0,344 & 0,261 \\
\hline BAC08 & 20,94 & 29,38 & 0,462 & 0,410 \\
\hline BAC09 & 21,07 & 29,81 & 0,249 & 0,344 \\
\hline BAC10 & 20,57 & 30,82 & 0,320 & 0,242 \\
\hline BAC11 & 20,62 & 30,86 & 0,207 & 0,196 \\
\hline NWS01 & 21,01 & 29,35 & 0,471 & 0,421 \\
\hline NWS02 & 21,00 & 29,49 & 0,491 & 0,393 \\
\hline NWS03 & 21,06 & 30,33 & 0,430 & 0,242 \\
\hline NWS04 & 21,08 & 29,38 & 0,501 & 0,432 \\
\hline NWS05 & 21,14 & 30,49 & 0,396 & 0,229 \\
\hline NWS06 & 20,93 & 30,18 & 0,351 & 0,259 \\
\hline NWS07 & 21,12 & 30,28 & 0,301 & 0,265 \\
\hline NWS08 & 21,13 & 30,74 & 0,228 & 0,177 \\
\hline NWS09 & 21,08 & 30,02 & 0,365 & 0,305 \\
\hline NWS10 & 21,18 & 30,15 & 0,295 & 0,317 \\
\hline NWS11 & 21,10 & 30,26 & 0,255 & 0,262 \\
\hline VA01 & 20,52 & 31,09 & 0,171 & 0,225 \\
\hline VA02 & 20,59 & 30,28 & 0,302 & 0,365 \\
\hline VA03 & 20,66 & 29,82 & 0,407 & 0,412 \\
\hline VA04 & 20,71 & 30,21 & 0,382 & 0,295 \\
\hline VA05 & 21,11 & 30,08 & 0,212 & 0,302 \\
\hline VA06 & 20,82 & 29,45 & 0,481 & 0,410 \\
\hline AMA01 & 20,52 & 31,11 & 0,270 & 0,216 \\
\hline AMA02 & 20,57 & 30,69 & 0,491 & 0,287 \\
\hline AMA03 & 20,71 & 30,11 & 0,474 & 0,315 \\
\hline AMA04 & 20,58 & 30,34 & 0,443 & 0,359 \\
\hline AMA05 & 20,59 & 30,31 & 0,465 & 0,361 \\
\hline AMA06 & 20,69 & 29,96 & 0,388 & 0,358 \\
\hline
\end{tabular}

